\title{
Final Report Start-Up and Commissioning Tests on the DuraMelter 1200 HLW Pilot Melter System Using AZ-101 HLW Simulants VSL-01R0100-2, Rev. 0, 1/20/03
}

Prepared for the U.S. Department of Energy

Assistant Secretary for Environmental Management

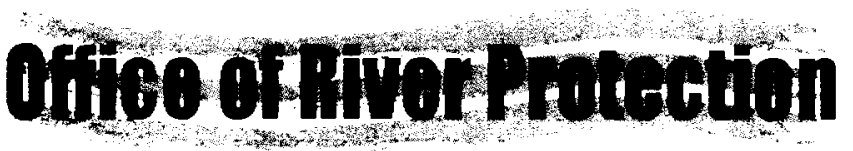

P.O. Box 450

Richland, Washington 99352

Approved for Public Release;

Further Dissemination Unlimited 
ORP-51437

Revision 0

\section{Final Report Start-Up and Commissioning Tests on the DuraMelter 1200 HLW Pilot Melter System Using AZ-101 HLW Simulants VSL-01R0100-2, Rev. 0, 1/20/03}

K. S. Matlack

Vitreous State Laboratory,

The Catholic University of America

A. A. Kruger
Department of Energy - Office of River Protection
W. K. Kot

M. Brandys

C. N. Wilson

T.R. Schatz

W. Gong

I. L. Pegg

Vitreous State Laboratory,

The Catholic University of America

Date Published

December 2011

Prepared for the U.S. Department of Energy

Assistant Secretary for Environmental Management

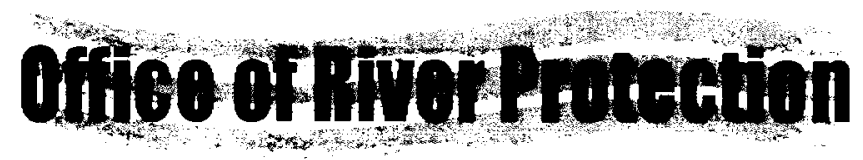

P.O. Box 450

Richland, Washington 99352

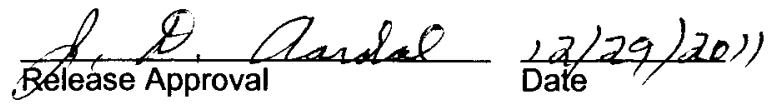


ORP-51437

Revision 0

TRADEMARK DISCLAIMER

Reference herein to any specific commercial product, process, or service by trade name, trademark, manufacturer, or

otherwise, does not necessarily constitute or imply its endorsement, recommendation, or favoring by the United

States Government or any agency thereof or its contractors or subcontractors.

This report has been reproduced from the best available copy.

Printed in the United States of America 


\title{
Final Report
}

Start-Up and Commissioning Tests on the DuraMelter 1200 HLW Pilot Melter System Using AZ-101 HLW Simulants

\author{
prepared by
}

Keith S. Matlack, Wing K. Kot, Marek Brandys, Charles N. Wilson, Timothy R. Schatz, Weiliang Gong, and Ian L. Pegg

\author{
Vitreous State Laboratory \\ The Catholic University of America \\ Washington, DC 20064 \\ for \\ Duratek, Inc. \\ and \\ Bechtel-Washington
}

October 31, 2001

Rev. $0,1 / 20 / 03$ 
The Catholic University of America Vitreous State Laboratory
DuraMelter 1200 Start-Up Tests with AZ-101 Final Report, VSL-01R0100-2, Rev.0

\section{Document Revision Log}

Rev. 0, 10/31/01

Rev. $0,1 / 20 / 03$
Original draft for external review.

Incorporates WTP comments. 
The Catholic University of America

DuraMelter 1200 Start-Up Tests with AZ-101

Vitreous State Laboratory Final Report, VSL-01R0100-2, Rev.0

\section{Table of Contents}

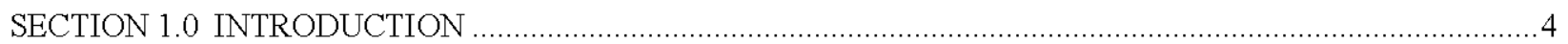

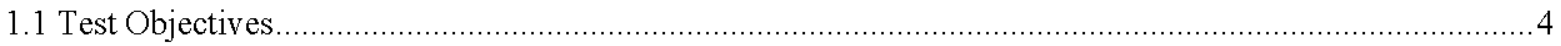

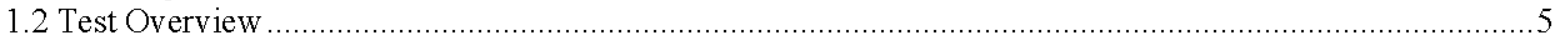

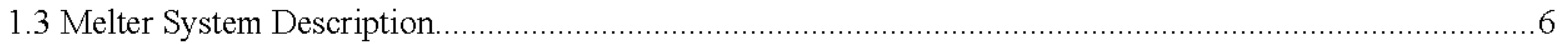

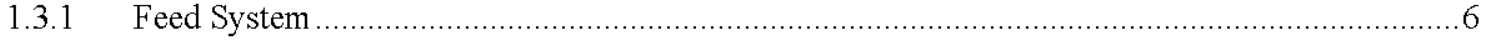

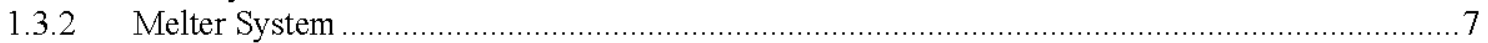

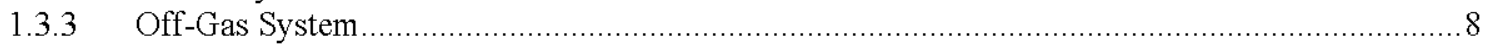

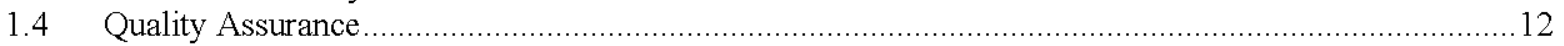

SECTION 2.0 WASTE SIMULANT AND GLASS FORMULATIONS ……...........................................

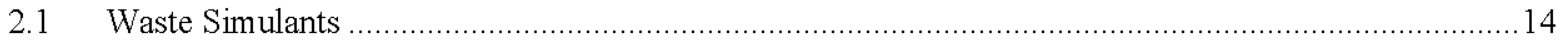

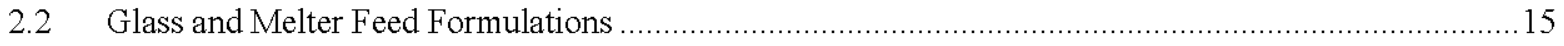

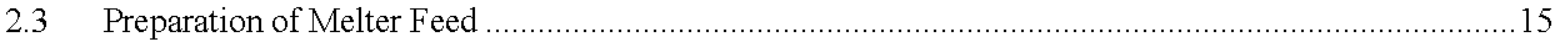

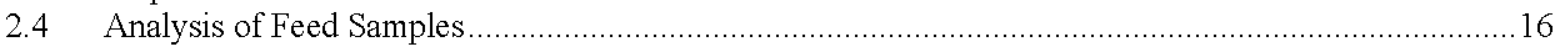

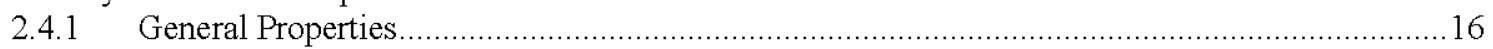

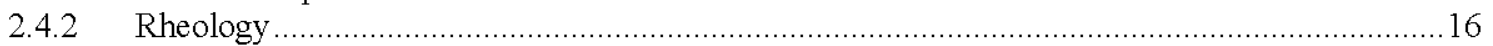

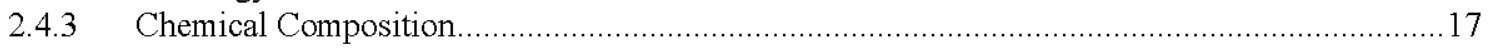

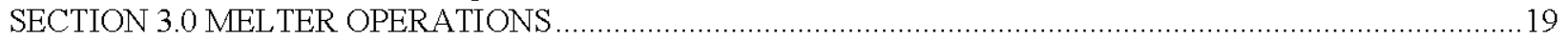

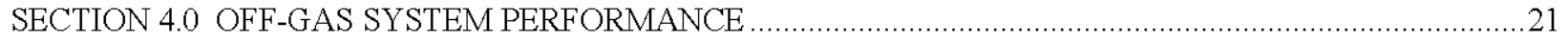

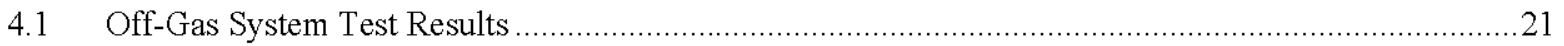

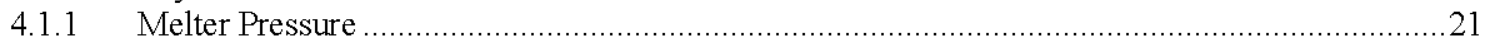

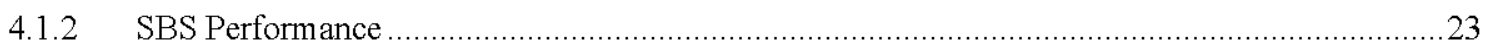

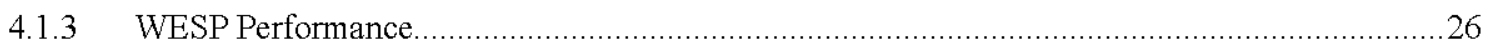

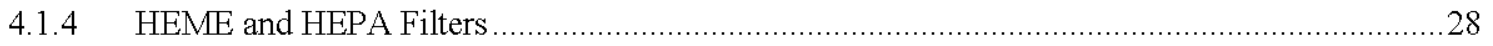

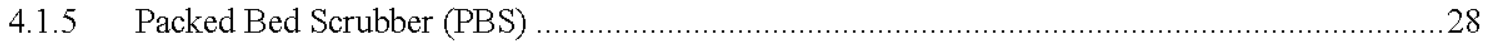

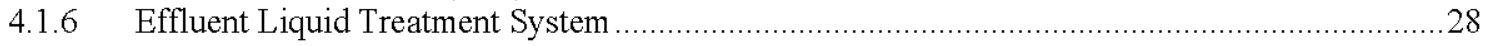

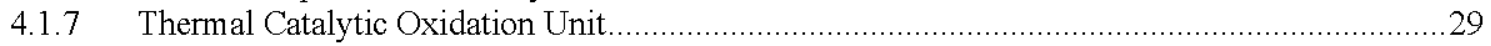

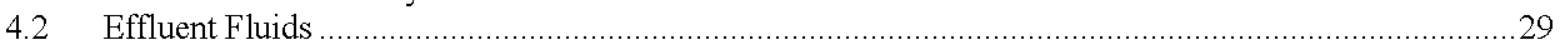

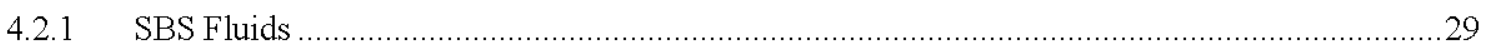

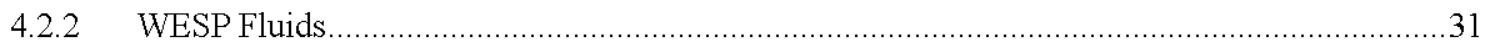

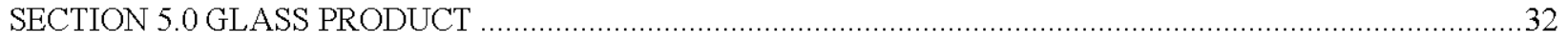

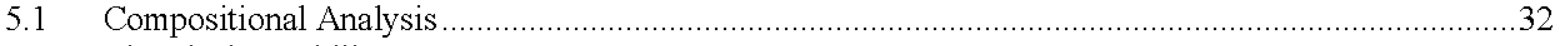

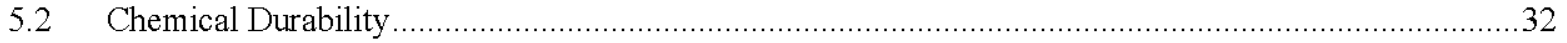

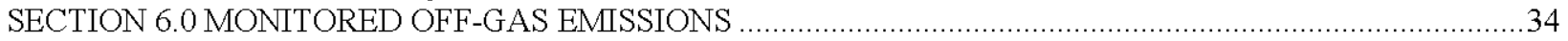

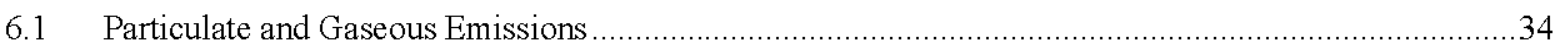

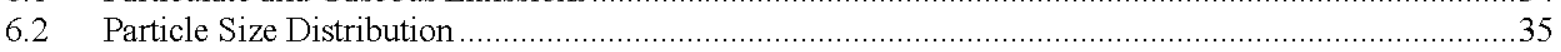

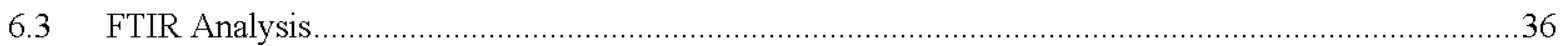

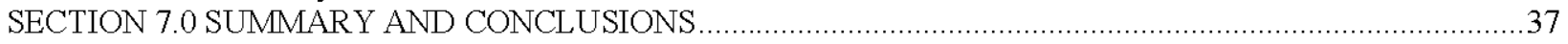

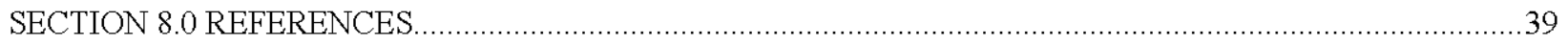

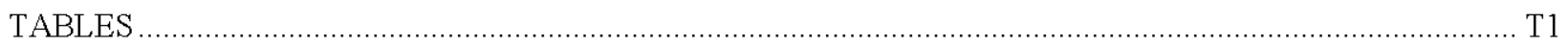

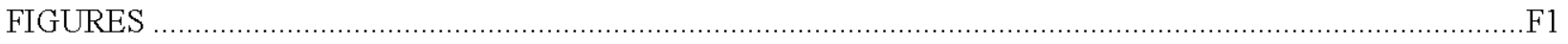


The Catholic University of America

Vitreous State Laboratory
DuraMelter 1200 Start-Up Tests with AZ-101

Final Report, VSL-01R0100-2, Rev.0

\section{SECTION 1.0 INTRODUCTION}

This document provides the final report on data and results obtained from commissioning tests performed on the one-third scale DuraMelter ${ }^{\mathrm{TM}} 1200$ (DM1200) HLW Pilot Melter system that has been installed at VSL with an integrated prototypical off-gas treatment system. That system has replaced the DM1000 system that was used for HLW throughput testing during Part B1 [1]. Both melters have similar melt surface areas $\left(1.2 \mathrm{~m}^{2}\right)$ but the DM1200 is prototypical of the present RPPWTP HLW melter design whereas the DM1000 was not. These tests were performed under a corresponding RPP-WTP Test Specification [2] and associated Test Plan [3]. This report is a followup to the previously issued Preliminary Data Summary Report [4].

The DM1200 system will be used for testing and confirmation of basic design, operability, flow sheet, and process control assumptions as well as for support of waste form qualification and permitting. This will include data on processing rates, off-gas treatment system performance, recycle stream compositions, as well as process operability and reliability. Consequently, this system is a key component of the overall HLW vitrification development strategy. The results presented in this report are from the initial series of short-duration tests that were conducted to support the start-up and commissioning of this system prior to conducting the main body of development tests that have been planned for this system [5,6]. These tests were directed primarily at system "debugging," operator training, and procedure refinement. The AZ-101 waste simulant and glass composition that was used for previous testing [1,7-9] was selected for these tests.

\section{$1.1 \quad$ Test Objectives}

The principal objectives of this work were to:

- $\quad$ Bring the DM1200 system to full routine operating status by performing tests to diagnose and correct any remaining system issues.

- $\quad$ Refine operating procedures as needed in response to commissioning test findings.

- Complete operator training.

- Conduct final confirmation of instrumentation, control, and data acquisition systems.

- Determine routine operating parameter ranges for system components. 
The Catholic University of America

Vitreous State Laboratory
DuraMelter 1200 Start-Up Tests with AZ-101

Final Report, VSL-01R0100-2, Rev.0

- Collect emissions data for local regulatory purposes.

Secondary objectives included:

- Obtain data on the effects of key operating parameters (feed water content and glass bubbling) on glass production rates and melter emissions.

- Identify possible processing problems such as foaming, secondary phase formation, and poor cold cap characteristics, particularly in comparison to previous small-scale and DM1000 melter tests.

- $\quad$ Evaluate off-gas system component efficiency by sampling exhaust at various points in the off-gas system as well as sump solutions from the various components.

- Collect data on product glass composition and product quality.

- Collect data on mass balance across the melter.

- $\quad$ Collect operating data with a simulated air-displacement slurry (ADS) pump melter feed system (i.e., intermittent, pulsed flow of feed to the melter), particularly with respect to off-gas transients.

\subsection{Test Overview}

The DM1200 system and the test matrix are described in the Test Plan [3]. A detailed description of the off-gas treatment system has also been provided [8]. In addition, the results of extensive off-line testing of the submerged-bed scrubber (SBS), which was performed prior to the present tests, have also been reported [11].The commissioning tests were composed of four test segments, during which, a total of $10,500 \mathrm{~kg}$ of glass was produced:

- Turnover-during which the glass inventory (about $1700 \mathrm{~kg}$ ) was turned over from the start-up frit composition to the AZ-101 glass composition. About $5000 \mathrm{~kg}$ of glass was produced during this period.

- Test 1 - High-solids feed, very low bubbling (4 scfh); 120 hours, $1587 \mathrm{~kg}$ glass produced. 
The Catholic University of America

Vitreous State Laboratory
DuraMelter 1200 Start-Up Tests with AZ-101

Final Report, VSL-01R0100-2, Rev.0

- Test 2 - High-solids feed, with bubbling (120 scfh); 50 hours, $1948 \mathrm{~kg}$ glass produced.

- Test 3 - Low-solids feed, with bubbling (120 scfh); 50 hours, $1922 \mathrm{~kg}$ glass produced.

All of the tests were performed with the same waste simulant and glass composition [3], a nominal glass pool temperature of $1150^{\circ} \mathrm{C}$, essentially complete cold cap coverage, and a nominal plenum temperature between $400-600^{\circ} \mathrm{C}$. Side-to-side electrode firing was used (the bottom electrode was not powered) and one of the two installed feed tubes was used in order to more closely reflect the number of feed tubes per unit area planned for the full-scale HLW melter. Bubbling was from the bottom electrode bubblers. The high- and low-solids melter feeds had nominal glass yields of 570 and $350 \mathrm{~g} / 1$, respectively. Table 1.1 provides a summary of the test conditions and production rate data for each test.

\subsection{Melter System Description}

\subsubsection{Feed System}

The feed material for these tests was prepared by a chemical supplier, as detailed in Section 2. Each batch of feed slurry was shipped to VSL in lined 55-gallon drums (approximately 16 per shipment) and staged for unloading into the mix tank. Both the mix tank and the feed tank are 750 -gallon polyethylene tanks with conical bottoms that are fitted with mechanical agitators. Five calibrated load cells directly mounted on the legs of the feed tank were used to measure additions to and removal from the feed tank and were electronically monitored to determine the feed rate to the melter. The requisite amount of feed is pumped to the feed tank from the mix tank; measured amounts of water were combined with the feed at this point for the high-water feed tests. The material in the feed tank is constantly recirculated from the feed tank discharge outlet, at the tank bottom, to the tank inlet at the top, which provides additional mixing.

The way in which the feed is introduced into the melter is designed to mimic the operation of an ADS pump, which is the present RPP-WTP baseline. The recirculation loop extends to the top of the melter where feed is diverted from the recirculation loop into the melter through two parallel Teflon-lined feed lines and water-cooled feed tubes. Three computer-operated pinch valves, one on each of the feed lines and one on the recirculation loop, are activated in a timed sequenced to introduce feed into the melter at the desired rate. The feed rate is regulated by adjusting the length of each pulse, the time between each pulse, and the pressure applied to the recirculation loop. A 
The Catholic University of America

Vitreous State Laboratory
DuraMelter 1200 Start-Up Tests with AZ-101

Final Report, VSL-01R0100-2, Rev.0

compressed air line is attached to each of the feed lines and can be used to automatically clear the feed lines (feed and "chase air") into the melter after each pulse.

\subsubsection{Melter System}

The DuraMelter ${ }^{\mathrm{TM}} 1200$ is a Joule-heated melter with Inconel 690 electrodes and thus has an upper operating temperature of about $1200^{\circ} \mathrm{C}$. The melter shell is water-cooled and incorporates a jack-bolt thermal expansion system. The footprint of the melter is approximately $8 \mathrm{ft}$. by $6.5 \mathrm{ft}$. with a $4 \mathrm{ft}$. by $2.3 \mathrm{ft}$. air-lift discharge chamber appended to one end; the melter shell is almost $8 \mathrm{ft}$. tall. The melter surface area and the melt pool height are approximately 32 percent and 57 percent, respectively, of the corresponding values for the full-scale HLW melter. The discharge riser and trough are full-scale to verify pouring adequacy. Other aspects of the discharge system are also prototypical such as the chamber ventilation scheme. The glass contact refractory is Monofrax ${ }^{\mathrm{TM}} \mathrm{K}$ 3 while the plenum area walls are constructed of Monofrax ${ }^{\mathrm{TM}} \mathrm{H}$ refractory. The surface of the glass pool is 34 " by 54 " with a glass depth of nominally 25 ". The resultant melt volume is approximately 45,000 cubic inches ( 735 liters), which represents a glass tank capacity of more than 1.7 metric tons of glass. As compared to the two parallel pairs of flat plate electrodes in the former DuraMelter ${ }^{\mathrm{TM}}$ 1000 , the DuraMelter ${ }^{\mathrm{TM}} 1200$ is fitted with one pair of electrodes placed high on opposite walls of the melter as well as one bottom electrode. The side electrodes are 11 " by 34 " giving an electrode area for the pair of about $750 \mathrm{sq}$. in. Depending on the glass level, the plenum space extends about $33 "$ to $36 "$ above the melt surface resulting in a plenum volume ranging from about 43 to $46 \mathrm{ft}^{3}$. Cross-sectional diagrams of the melter illustrating the discharge chamber and electrode configuration are provided in Figures 1 and 2.

The single-phase power supply to the melter electrodes $(250 \mathrm{~kW}$ designed power $)$ is derived from the DuraMelter ${ }^{\mathrm{TM}} 1000$ transformers by wiring them in parallel and using a single large silicon controlled rectifier (SCR). Current can be passed either from the side electrodes to the bottom electrode or between the two side electrodes only, by rearranging jumpers. Programmable process controllers are installed and can be used to control temperature or power. It is convenient to control the melt temperature by configuring the process controller to maintain constant power and adjusting the power set-point as needed to maintain the desired operating temperature. Alarms can be set to detect out-of-range temperatures or power in the melter. Backup process controllers are installed to be used in case of failure of the main controllers.

The DuraMelter ${ }^{\mathrm{TM}} 1200$ has several others features worth noting. The lid refractory is prototypic and also includes a two-piece construction, which simulates the seam that was part of the full-scale LAW lid, which was to have been fabricated in three pieces; however, that design element of the LAW lid has since been revised. Nozzles are provided for the off-gas film cooler, a standby off-gas port, discharge airlift, along with 11 ports available for top-entering bubblers, start-up 
The Catholic University of America

Vitreous State Laboratory
DuraMelter 1200 Start-Up Tests with AZ-101

Final Report, VSL-01R0100-2, Rev.0

heaters and other components as needed. In addition, a bubbler arrangement is installed in the bottom electrode with the objective of developing permanent bubblers for possible use on future melters. Another innovation is a fiber optic distributed temperature monitor that is cast into the Narcon $^{\mathrm{TM}} 60 \mathrm{~A}$ castable on the discharge chamber side of the DM1200 that is intended to demonstrate the use of a distributed temperature sensor for refractory corrosion monitoring.

\subsubsection{Off-Gas System}

The DM-1200 off-gas system was designed to be prototypic of the off-gas treatment system planned for use with the HLW melters in the RPP-WTP facility. In addition, the system can be reconfigured to represent the LAW off-gas treatment train for testing with LAW feeds. A detailed description of the design and installation of the DM-1200 off-gas system was provided earlier [10]. A schematic process flow diagram showing the components of the system is provided in Figure 1.3.

\subsubsection{Functional description}

The melter and the entire off-gas treatment system are maintained under slight negative pressure by external induced draft blowers. This negative pressure is necessary to minimize escape of gases from the system into the working spaces surrounding the melter and is prototypical of the full-scale system. The off-gas treatment system, shown schematically in Figure 1.3, consists of a submerged bed scrubber (SBS); a wet electrostatic precipitator (WESP); a high-efficiency mist eliminator (HEME); a high-efficiency particulate arrestor (HEPA); a packed-column caustic scrubber (PBS); a second HEME; a thermal catalytic oxidation unit (TCO); and a second HEPA as the primary treatment units. Differences between the DM1200 off-gas system and the RPP-WTP baseline design include the addition of intermediate blowers and a second High Efficiency Mist Eliminator (HEME) after the caustic scrubber in the pilot system. The second HEME can be bypassed if necessary but the VSL design team judged this a necessary addition in order to prevent undesirable salt carryover into the TCO unit. Several changes have been made to the RPP-WTP baseline design since the deployment of the DM1200 system, including the replacement of the packed-bed scrubber by a silver mordenite column for iodine removal located after the TCO. The Project is evaluating the addition of a silver mordenite column to the DM1200 system; for the present test, however, the packed bed scrubber was not operated.

The system can be functionally subdivided into four subsystems:

$\underline{\text { Particulate Removal: }}$

Components from the submerged bed scrubber (SBS) to HEPA \#1 serve to remove essentially all of the particulate from the gas stream with an estimated removal efficiency of greater than $99.9999 \%$ for particles greater than $0.3 \mu \mathrm{m}$ in size. In the RPP-WTP facility, this 
The Catholic University of America

Vitreous State Laboratory

provision serves to segregate the radioactive from the non-radioactive components in the system for maintenance and handling purposes.

Acid Gas/VOC Control: The caustic scrubber and HEME \#2 provide acid gas scrubbing to protect the thermal catalytic oxidation (TCO) unit, which is designed to oxidize any hazardous organics that are present in the off-gas stream. However, as noted above, the caustic scrubber was by-passed for these tests. In addition, no catalyst was installed in the TCO for the present tests.

Stack System:

Components from HEPA \#2 to the stack outlet, including the emergency/bypass exhaust system, provide final filtration of the gas and serve to exhaust the treated gas stream to the atmosphere.

Liquid Processing:

Components including the water spray lines, liquid sampling and water storage tanks, as well as the effluent evaporator, function to sample and process the system liquids for recycle or discharge.

Initial quenching of the gas stream from the melter takes place in the film cooler. Gas exits the film cooler at a temperature of 250 to $350{ }^{\circ} \mathrm{C}$ flowing at a rate of typically $100-250 \mathrm{scfm}$, of which $5-50 \mathrm{scfm}$ is water vapor, depending on the operating conditions. The off-gas is then rapidly quenched by direct liquid water contact in the Submerged Bed Scrubber (SBS), which also effects removal of most of the larger particulates. High superficial gas velocity in the piping between the film cooler and SBS minimizes particulate deposition. Gas leaves the SBS at a relatively low temperature (typically between 35 and $50{ }^{\circ} \mathrm{C}$ ). Further mist and particulate removal continues in the WESP, HEPAs, and HEMEs. Water deluge nozzles are installed in WESP and HEMEs to wash down deposits into their respective collection sumps. The system components are fabricated from corrosion resistant materials including AL6XN in the SBS and 316L stainless steel and various plastics in other locations. There are extensive provisions for sampling both the gas and liquid streams throughout the system in order to collect mass balance information and removal efficiency data for each treatment stage.

\subsubsection{1 $\quad$ SBS Modifications}

Several modifications were made to the SBS as a result of data collected during initial standalone testing using Landa evaporator as an off-gas/steam source simulator [11] and subsequent testing by feeding the DM1200 melter with water; these are briefly summarized here for background. Significant among the issues were: 
The Catholic University of America

Vitreous State Laboratory
DuraMelter 1200 Start-Up Tests with AZ-101

Final Report, VSL-01R0100-2, Rev.0

- Excessive fluctuations in melter pressure attributed to oscillations on the large gas bubble that forms underneath of the SBS diffuser plate at the exit of the downcomer pipe.

- Rapid disintegration of the ceramic saddle packing media that was originally specified by the RPP-WTP Project.

- A need for supplemental cooling to handle the increased steam flow into the SBS at the higher processing rates that are realized when the glass pool is agitated by bubbling.

Several modifications were tested, including extension of the center inlet downcomer below the diffuser plate and alternative packing media. A perforated downcomer extension tube extending 12 inches below the diffuser plate was installed with holes along the tube wall with the intent of breaking up the gas bubble forming below the diffuser plate. This change reduced the amplitude of the pressure pulsations to an acceptable level. Several other changes were also investigated, such as plugging weir tubes, plugging the standby gas nozzle, and constraining the inlet source of gas. However, the perforated downcomer extension appeared to have the most effect in mitigating the pressure fluctuations. In the downcomer extension used during the commissioning tests there were 32 half-inch diameter holes distributed along the tube in four rows of eight, $1 \frac{1}{2}$ inch apart.

Various packing media, including $1 / 2$ inch stainless steel saddles, metal balls, and ceramic balls were tested in place of the original ceramic Intallox saddle packing medium. Based on these tests, ceramic balls, approximately an inch in diameter, packed all the way up to the top retaining screen were used during the commission testing. However, the original Intallox saddles were retained in the spaces between the liquid weirs that protruded through the diffuser plate to prevent jamming of the ceramic balls in crevices. A metal screen was laid on top of the weirs to eliminate intermixing of packing media.

During "water runs" that were performed prior to the commissioning tests, the performance of the integrated DM1200 off-gas system was evaluated by feeding water to the melter at rates as high as 2.5 liters per minute, both continuously and in a pulsed manner to mimic the ADS feed pump. Initially, water feed rates in excess of one liter per minute resulted in substantial moisture condensation downstream of the SBS. Even with the cooling jacket of the SBS working at full capacity, the sump operated at a temperature of about $60^{\circ} \mathrm{C}$ to $70^{\circ} \mathrm{C}$. While this would not be a problem with the lower feed processing rates achieved without bubbling, the heat load to the SBS would be excessive with the higher processing rates anticipated during test runs with bubbling of the glass melt pool. To temporarily alleviate the problem, an external heat exchanger was added to decrease the operating temperature of the SBS and minimize down-stream moisture condensation. 
This was accomplished by re-circulating the SBS sump liquid through a plate heat exchanger and returning it to the SBS via the jet stirring lances, which were operated continuously ${ }^{1}$. With the added plate heat exchanger cooling, it was possible to maintain the dew point of the gas leaving the SBS in a range of 23 to $29^{\circ} \mathrm{C}$, resulting in stack exhaust gas of $2-3 \%$ relative humidity at $90-95^{\circ} \mathrm{C}$. During steady-state operation, the gas flow from the SBS varied between 180 and $220 \mathrm{scfm}$ with the film cooler injection flow set at $70 \mathrm{scfm}$. Following addition of the plate heat exchanger, no unwanted condensation of moisture was observed anywhere along the off-gas train.

\subsubsection{Data Acquisition}

During the commissioning test runs, off-gas data from most measurement points were logged at two-minute intervals by a PC-based data acquisition system using LabVIEW2 software. The following is a list of off-gas system data electronically logged during these tests:

\section{$\underline{\text { Melter }}$}

- Melter plenum pressure relative to room ("gauge" pressure, in W.C.)

\section{$\underline{\text { SBS }}$}

- Inlet gas pressure relative to room ("gauge" pressure, in W.C.)

- Outlet gas pressure relative to room ("gauge" pressure, in W.C.)

- Differential pressure (in W.C.) across the SBS

- Temperature $\left({ }^{\circ} \mathrm{C}\right)$ of the chilled cooling water supplied to the SBS external cooling jacket and to the plate heat exchanger

- Outlet temperature $\left({ }^{\circ} \mathrm{C}\right)$ of cooling water from the SBS external cooling jacket

- Flow rate (gpm) of cooling water through the SBS external cooling jacket

- Outlet temperature $\left({ }^{\circ} \mathrm{C}\right)$ of cooling water from the SBS plate heat exchanger

- Flow rate (in gpm) of cooling water through the SBS plate heat exchanger

- Liquid temperature $\left({ }^{\circ} \mathrm{C}\right)$ inside of SBS at four depths $(48,60,72$ and 78 inches) below

\footnotetext{
${ }^{1}$ A permanent, internal cooling coil utilizing chilled process water replaced this temporary modification prior to the next sequence of tests. Such a coil is included in the RPP-WTP baseline SBS design but was deleted from the DM1200 SBS in Part B1 as a cost saving measure.

${ }^{2}$ National Instruments Corporation, Austin Texas.
} 
The Catholic University of America

Vitreous State Laboratory

the overflow level
DuraMelter 1200 Start-Up Tests with AZ-101 Final Report, VSL-01R0100-2, Rev.0

WESP

- Differential pressure (in W.C.) across the WESP

- Inlet gas temperature $\left({ }^{\circ} \mathrm{C}\right)$

- Outlet gas temperature $\left({ }^{\circ} \mathrm{C}\right)$

$\underline{\text { HEPA \#1 }}$

- Differential pressure (in W.C.) across HEPA \#1

- Outlet gas temperature $\left({ }^{\circ} \mathrm{C}\right)$

$\underline{\text { Caustic Scrubber }}$

- Inlet gas temperature $\left({ }^{\circ} \mathrm{C}\right)$

$\underline{\text { Neutralization tank }}$

- $\mathrm{pH}$ of liquids in neutralization tank

$\underline{\mathrm{TCO}}$

- Outlet gas temperature $\left({ }^{\circ} \mathrm{C}\right)$

\subsection{Quality Assurance}

This work was conducted under an NQA-1 (1994) based quality assurance program that is in place at VSL. This program was supplemented by a Quality Assurance Project Plan for RPP-WTP work [12] that is conducted at VSL, which includes the correlation of the VSL QA program with the contractually imposed 10-CFR-830.120. This work is not subject to DOE/RW-0333P. The special requirements of EPA Guidance for Quality Assurance Project Plan (EPA QA/G-5) do not apply to this work. Since the completion of this work, the RPP-WTP Project has directed the implementation of an NQA-1 (1989) and NQA-2a (1990) subpart 2.7, in place of NQA-1 (1994) and the VSL program and Quality Assurance Project Plan for RPP-WTP work that is conducted at VSL has been 
The Catholic University of America

Vitreous State Laboratory
DuraMelter 1200 Start-Up Tests with AZ-101 Final Report, VSL-01R0100-2, Rev.0

revised accordingly [13]. The program is supported by VSL standard operating procedures that were used for this work [14]. 


\section{SECTION 2.0 \\ WASTE SIMULANT AND GLASS FORMULATIONS}

\subsection{Waste Simulants}

The AZ-101 HLW simulant that was used for these tests is based on waste compositions provided in the Tank Waste Remediation System Operation and Utilization Plan (TWRS-OUP) [15]. The TWRS-OUP provides inventory information on 24 major waste components, which is, for the most part identical to that found in the Best Basis Inventory (BBI) database [16]; the exceptions are mercury, which is omitted in the TWRS-OUP, and strontium, for which the higher of the two values was assumed in this work. The TWRS-OUP, in addition to total inventories, provides the information on the partitioning of those inventories into solid and supernatant fractions that is needed to define waste simulants. The chemical wash factors that are provided in the TWRS-OUP were applied to the solid fractions in defining the AZ-101 simulant. For waste components that are not tracked in the TWRS-OUP or the BBI, data from the HLW Feed Staging Plan [17] based on the recommended number of in-tank sludge washings were used. No radionuclides or noble metals were included and all constituents present at less than $0.05 \mathrm{wt} \%$ (waste oxide basis) were omitted. In addition, all of the TOC was assumed to be oxalate and the small amounts of boron, lithium, and zinc were omitted since much greater amounts are present in the glass forming additives. While it was recognized that more recent information was available (e.g., in the Tank Farm Contractor Operation and Utilization Plan [18]) the compositional changes for AZ-101 are not great. Furthermore, it was judged more important to keep exactly the same simulant and melter feed composition for these tests as those used previously [1,7-9] in order to be able to directly compare the test results.

A total of 32 chemical components are present in the resulting simulant for the washed AZ101 HLW (Table 2.1). This HLW material must then be blended with the projected products from LAW pretreatment to complete the waste simulant formulation. These pretreatment processes (Cs and $\mathrm{Tc}$ removal by ion exchange and $\mathrm{Sr}$ /TRU removal by $\mathrm{Sr} /$ permanganate precipitation) lead to increases in the amounts of cesium, technetium, sodium, nitrate, strontium, and manganese in the HLW material. The pretreatment products from technetium removal, which contribute technetium, sodium, and nitrate, were neglected in the simulant since the impact on nitrate is relatively small ( 75 liters of Tc concentrate vs. 3,811 liters of Cs concentrate [19]) and sodium is used as a glass forming additive. The quantities of pretreatment products to be combined with the AZ-101 HLW material were calculated based on References [19] and [20]. In particular, 7.71\% of the total $\mathrm{Sr} / \mathrm{TRU}$ precipitate from pretreatment of Envelope $\mathrm{C}$ waste is to be added to AZ-101 waste, which is 
The Catholic University of America

Vitreous State Laboratory
DuraMelter 1200 Start-Up Tests with AZ-101

Final Report, VSL-01R0100-2, Rev.0

equivalent to $(78 \mathrm{MT} \times 0.0771)=6.01 \mathrm{MT}$ of strontium and $(38 \mathrm{MT} \times 0.0771)=2.93 \mathrm{MT}$ of manganese. The strontium precipitate will probably consist of a combination of carbonate and hydroxide. We have assumed that the carbonate is predominant and have included $3 \mathrm{~g}$ of carbonate per $100 \mathrm{~g}$ of oxides in the simulant (no carbonate is present in the washed HLW material as a consequence of the assumed $100 \%$ wash factor for carbonate [15]). The composition of the resulting AZ-101 simulant mixed with pretreatment products is summarized in Table 2.1. Subsequent to the Turnover and prior to Test 1 , potassium iodide (at the expense of potassium nitrate) was added to the feed to achieve a target glass composition of 0.1 weight percent iodine if all of the iodine were retained.

\subsection{Glass and Melter Feed Formulations}

Glass formulations have been developed for the AZ-101 simulant that accommodate the replacement of iron by manganese for $\mathrm{Sr} / \mathrm{TRU}$ removal and meet the processing and product quality requirements. The glass composition selected for these tests, HLW98-31, is presented in Table 2.1. On an oxide basis, this glass incorporates $27.0 \mathrm{wt} \%$ of Envelope D waste and $3.5 \mathrm{wt} \%$ of pretreatment products; the resulting content of $\mathrm{MnO}$ is $3.03 \mathrm{wt} \%$. Crucible, DM10, DM100, and DM1000 tests have been conducted to determine that this glass meets all processing and performance requirements [1, 7-9]. The measured viscosity and conductivity at $1150^{\circ} \mathrm{C}$ are $43 \mathrm{P}$ and $0.41 \mathrm{~S} / \mathrm{cm}$, respectively. Heat treatment of HLW98-31 at $950^{\circ} \mathrm{C}$ for 70 hours resulted in 0.26 vol\% of spinel while the glass was completely homogeneous after 66 hours at $1050^{\circ} \mathrm{C}$. The glass also shows good TCLP performance: the Cd concentration in the TCLP leachate is $0.067 \mathrm{mg} / 1$, compared to the Universal Treatment Standard (UTS) level of $0.11 \mathrm{mg} / 1$, while all other constituents are below their respective UTS levels by much wider margins.

The additional constituents required to form HLW98-31 glass from the AZ-101 simulant are boron, lithium, sodium, silicon, and zinc. The corresponding chemical additives that are the sources for these elements were selected based upon cost and compatibility with the vitrification process. The theoretical glass yield of the resulting feed is $0.39 \mathrm{~kg}$ of glass per $\mathrm{kg}$ of feed, which is equivalent to $0.55 \mathrm{~kg}$ of glass per liter of feed based on a density of the feed of $1.40 \mathrm{~g} / \mathrm{ml}$.

\subsection{Preparation of Melter Feed}

Early in B1 VSL solicited bids from vendors to collaborate in simulant and feed development and to supply material for the large-scale melter tests, which resulted in the selection of NOAH Technologies Corporation. NOAH Technologies' Quality Assurance program has been reviewed and approved by VSL. NOAH Technologies has produced the simulant and feed samples used in 
The Catholic University of America

Vitreous State Laboratory
DuraMelter 1200 Start-Up Tests with AZ-101

Final Report, VSL-01R0100-2, Rev.0

development and screening tests conducted to date at VSL as well as larger-scale tests on the DM100 and DM1000 melter systems.

Table 2.2 lists the starting materials and amounts required to generate the target AZ-101 simulant and feed. A total of about $26 \mathrm{MT}$ of feed was used, which resulted in about $10 \mathrm{MT}$ of glass. NOAH Technologies prepared the feed in batches based on their production capacity of about $4,000 \mathrm{~kg}$ per batch. The formulation was specified by VSL based on chemical assays of the raw materials provided by NOAH, or as necessary, assay samples of those materials performed by VSL. NOAH Technologies provided signed certificates of addition to VSL for each batch.

\subsection{Analysis of Feed Samples}

\subsubsection{General Properties}

Feed samples were analyzed from each received feed batch and from each test that was conducted to confirm physical properties and chemical composition. Sample names, sampling dates, sampling location, tank mass during sampling and measured properties are provided in Table 2.3. At the end of Test 3 , the residual feed was processed to determine if segregation occurs as the feed level falls well below the bottom mixer blades (last four samples in Table 2.3). Samples were simultaneously taken from the feed line and from the feed tank. Water was added to the AZ-101 feed for Test 3 to produce the low-solids feed, resulting in the observed lower densities and glass yields. The target glass yields of $570 \mathrm{~g} / 1$ for the first two tests and $350 \mathrm{~g} / 1$ for Test 3 were closely approximated for most of the testing periods. Exceptions occurred in the period after Test 3 when the feed level was below the mixer blade and the sample taken from the tank at the end of Test 2 . Aside from those exceptions, the measured parameters for these tests fall into relatively narrow ranges: water percent (51.6-53.8 for Test 1 and 2, 65.1-67.4 for Test 3 ), density (1.39-1.45 $\mathrm{g} / \mathrm{ml}$ for Test 1 and $2 ; 1.26-1.29 \mathrm{~g} / \mathrm{ml}$ for Test 3 ) and glass yield (534-573 g glass $/ 1$ feed for Test 1 and 2; and 324$367 \mathrm{~g} /$ liter Test 3). Given this similarity, the average values of 0.380 and $0.275 \mathrm{~kg}$ of glass per $\mathrm{kg}$ feed were used in calculating production rates for Tests 1 and 2 and for Test 3, respectively. Although analyses of samples taken from the feed line and the feed tank were very similar for most sample pairs, the feed line was selected as the standard sampling location for future tests. Furthermore, minimum amount of feed in the tank will be sufficient to ensure that good mixing is maintained (greater than about $1000 \mathrm{~kg}$, depending on feed density).

\subsubsection{Rheology}

Samples of the melter feeds that were used for these tests were also subjected to rheological characterization. The results from rheological characterization of a variety of other melter feeds and waste simulants, as well as the effects of a range of test variables, are described in detail in a 
The Catholic University of America

Vitreous State Laboratory
DuraMelter 1200 Start-Up Tests with AZ-101

Final Report, VSL-01R0100-2, Rev.0

separate report [15]. Melter feeds were characterized using a Haake RS75 rheometer, which was equipped with either a Z40DIN or a FL22-SZ40 sensor. A typical set of measurements consists of identifying the flow characteristics of the slurry by measuring the shear stress on the slurry at controlled shear rates and temperatures. In these measurements, the shear rate values are preset and are increased stepwise from $0.01 \mathrm{~s}^{-1}$ to $200 \mathrm{~s}^{-1}\left(70 \mathrm{~s}^{-1}\right.$ for FL22-SZ40) with a sufficient delay (typically 15 to 30 seconds) between steps to ensure that shear stress is allowed to fully relax and therefore measured at equilibrium. It should be noted that this approach is somewhat different than the "flow curve" approach that is often used in which the shear rate is ramped up to some maximum value and then ramped back down to produce a hysteresis curve that is dependent on the arbitrarily selected ramp rate. In contrast, the present measurements are equilibrium values of the shear stress at each measured shear rate. The viscosity of the sample as a function of the shear rate is then calculated as the ratio of the shear stress to the shear rate. All of the measurements in this work were made at $25^{\circ} \mathrm{C}$; previous work [15], which examined a range of temperatures, showed a relatively weak effect of temperature.

Rheograms for the melter feeds, which show the feed viscosity versus shear rate, are presented in Figure 2.1; measured values for viscosity at selected shear rates are compared in Table 2.4. As expected, the samples group into two distinct populations based on the solids content of the feed. The observed and expected reduction in viscosity with increased water contents has been observed in previous analysis of simulated HLW melter feeds [9, 21]. It is worth noting the small difference in viscosities between samples taken during Test 3 at the tank weight extremes suggesting limited feed segregation, even when the feed level is far below the bottom blade (probably a result of the effectiveness of the recirculation line flow in mixing the tank contents).

\subsubsection{Chemical Composition}

The chemical compositions of the feed samples were determined by first making a glass from the feed samples via crucible melt. The glass was subsequently crushed and either dissolved in an $\mathrm{HF} / \mathrm{HNO}_{3}$ acid mixture with the aid of a microwave oven to produce a solution for DCP analysis or analyzed directly by XRF. Boron and lithium oxide concentrations derived from the DCP procedure were used for normalizing the XRF data since those elements were not determined by XRF. The digested glass sample solutions were also analyzed for cesium using flame atomic absorption. Data from both methods are compared to each other and to the target composition in Table 2.5. These results generally corroborate the consistency of the feed composition and show good agreement with the target composition for the major elements. The measured lithium concentrations tended to be low but the results for an NIST standard glass (SRM 1412, $4.5 \mathrm{Wt} . \% \mathrm{Li}_{2} \mathrm{O}$ ) that is dissolved and analyzed with each set of glasses consistently yielded values within 7 percent of the standard value. The lithium results for several of the feed samples were rejected; these samples would normally have been reanalyzed but in view of the large number of comparable samples, all of which were derived 
The Catholic University of America

Vitreous State Laboratory
DuraMelter 1200 Start-Up Tests with AZ-101

Final Report, VSL-01R0100-2, Rev.0

from the same NOAH production batch, and the preliminary nature of these tests, these results were simply replaced by the average values for comparable samples, as indicated in Table 2.5. Values for zirconia generated by DCP were within $10 \%$ of target for all samples, however, as observed previously, the XRF results for zirconia are biased high as a result of limited relevant standards available for XRF. Some of the minor oxides which were targeted at less than $0.5 \mathrm{wt} \%$, such as $\mathrm{CaO}$ and $\mathrm{K}_{2} \mathrm{O}$, were consistently above target sometimes by as much as a factor of two, which may be a result of their presence as impurities in the raw materials. Volatile minor elements such as selenium, cesium, and chlorine are below target due to loss during crucible melting. The sum of analyzed oxides for DCP is below 100\% because not all elements are determined and there are minor losses during glass dissolution. Typically, sample recoveries for this procedure are about $95 \%$, however several of feed samples had lower values. In these instances, comparison with XRF results indicates the deficiency is mainly in silicon or iron. Good agreement between the two procedures exists for the majority of the other analytes. The total for the XRF results is always slightly greater than $100 \%$ due to post normalization correction to standard reference materials. Further comparison of XRF and DCP results for the products glass samples is provided in Section 5.1.

The large number of feed samples taken at various tank weights and two sampling locations provides data to evaluate the possibility of any chemical segregation in the feed tank. The concentrations of select soluble and insoluble oxides are plotted against feed tank mass in Figure 2.2. Notice the lack of correlation between concentrations and feed tank mass, except perhaps for the lowest tank reading. Also apparent is the agreement in analyzed sample chemistry between samples taken at the two different locations (i.e., tank and melter feed line). These data provide strong evidence that the melter feed was homogeneous throughout these tests. 
The Catholic University of America

Vitreous State Laboratory
DuraMelter 1200 Start-Up Tests with AZ-101

Final Report, VSL-01R0100-2, Rev.0

\section{SECTION 3.0 MELTER OPERATIONS}

Three melter tests were conducted on the DM1200 with the AZ-101 simulant between 5/7/01 and $5 / 24 / 01$, producing over $5400 \mathrm{~kg}$ of glass. Glass bubbling rate and feed water content were varied, as shown in the test summary in Table 1.1. Prior to beginning the tests, over $5000 \mathrm{~kg}$ of glass was produced during the turnover of the melt pool composition. The turnover was performed in a series of runs between 4/17/01 and 5/4/01 during which operators were trained, procedures were refined, and emissions data were collected for local regulators.

The measured glass production rates are depicted in Figures 3.1 - 3.3 as cumulative and fivehour moving averages. Note that only manually logged, instead of electronic, rate data were available for the first eight hours of Test 2. Typically, by the end of each test, the cumulative production rate approximates the five-hour average rate, indicating that steady-state rates have been approached. This was not the case in the test without bubbling because of the high rate achieved over the first day and half, even though steady-state was maintained for the last three days of the test. Overall, the test variable with the greatest effect on production rate was bubbling. Bubbling, by supplying air through the bottom electrode, resulted in an approximate five-fold increase in steadystate production rate from $155 \mathrm{~kg} / \mathrm{m}^{2} /$ day to $750 \mathrm{~kg} / \mathrm{m}^{2} /$ day. As expected, the production rate decreased with increasing feed water content, albeit modestly, from $750 \mathrm{~kg} / \mathrm{m}^{2} /$ day to 700 $\mathrm{kg} / \mathrm{m}^{2} /$ day. The low production rate in Test 1 is about half that achieved for the comparable test on the DM1000 [1] and about a third of that achieved on the DM100 [9]. The DM1000 test featured only 50 hours of slurry feeding and results in these and subsequent tests have indicated that often longer periods of time are required to reach steady state when bubbling is not used. The DM100 tests were of sufficient duration, however, normalized production rates are typically higher on smaller melters due to wall effects.

A variety of operational measurements were recorded during these melter tests including temperatures throughout the melter system, as given in Table 3.1. The target glass temperature of $1150^{\circ} \mathrm{C}$ was successfully maintained for at least one portion of glass pool during each of the tests, as illustrated in Figures 3.4 - 3.6. The coldest regions were between 27" and 30" from the floor due to the thermocouples being in or near the cold cap. The saw tooth pattern exhibited for these thermocouples is in response to the level changes associated with the pouring of glass over the course of each test. In tests with bubbling, the $1150^{\circ} \mathrm{C}$ target temperature was obtained at more locations throughout the melt pool resulting in more uniform temperature profile. Conversely, temperatures towards the bottom of the melter were generally lower in the test without bubbling (Figure 3.4) reflecting the poorer mixing. Glass temperatures measured in the East thermowell were lower than those measured at corresponding locations in the West thermowell. Plenum temperatures 
between $400-500^{\circ} \mathrm{C}$ were targeted and achieved for the steady-state portions of the tests. Since plenum temperature is a function of the extent to which the surface of the melt pool is covered by feed, plenum temperatures decrease over the course of each test as the cold cap develops, as shown in Figures 3.7 - 3.9. The discharge chamber temperature was maintained above $900^{\circ} \mathrm{C}$. Gas temperatures after film cooler dilution typically averaged between 250 and $300^{\circ} \mathrm{C}$, depending on the plenum temperature, the amount of added film cooler air, and the temperature of the added film cooler air.

The amount of power supplied to the electrodes depended on the feed rate, water content of the feed. Tests with higher feed rates (e.g., bubbled tests) required more power; however, when normalized to glass production, they had the lowest power utilization per unit glass produced. Notice in Table 1.1 that tests with bubbling required a half to a third the power per unit mass of glass. As expected, Test 3 required more power than Test 2 per unit mass of glass as a result of the higher feed water content. 
The Catholic University of America

Vitreous State Laboratory
DuraMelter 1200 Start-Up Tests with AZ-101

Final Report, VSL-01R0100-2, Rev.0

\section{SECTION 4.0 OFF-GAS SYSTEM PERFORMANCE}

These tests are the first in which this particular off-gas train has been operated with a jouleheated melter. This section presents and discusses data on the off-gas system performance obtained during the three commissioning test run segments following the initial glass turnover run. It should be noted, however, that these were start-up and commissioning tests and, accordingly, a significant amount of hardware and procedure debugging was performed during these tests.

\subsection{Off-Gas System Test Results}

Data for each system measurement channel logged by LabVIEW were imported into MS Excel files for data manipulation and plotting. Time " 0 " on the $\mathrm{x}$-axis of each data plot corresponds to the start of feeding of water to the melter at the beginning of each test run. Where indicated in the following discussion, some data were smoothed by time averaging instantaneous measurements logged at two minute intervals over a ten minute periods to reduce data scatter and narrow the width of line plots of the data. Table 4.1 includes the extreme and the average values for all off-gas system measured parameters.

\subsubsection{Melter Pressure}

Previously described modifications to the SBS reduced melter pressure fluctuations and improved melter pressure control. There was however, as shown in Figure 4.1, a temporary increase in melter plenum pressure following each periodic shot of feed injected by the pulsed feed system ${ }^{3}$. There is a small baseline pressure oscillation of approximately one-second duration and 0.5 in W.C. amplitude. A rapid increase of $\sim 5$ in W.C. follows each pulsed injection of feed. These data were collected using a fast ( $5 \mathrm{~ms}$ response time) pressure transducer opened to the melter plenum through a short run of wide-bore tubing. The cold cap was only partially developed at the time these measurements were taken (about $80 \%$ ). The periodic feed pressure pulses usually diminish as the cold cap coverage increases. Conversely, the pressure peaks are greater when feeding directly onto an exposed, hot glass surface. Thus, the feed start-up procedure used at West Valley has been adopted for the DM1200, wherein water is first fed in continuous stream to begin the formation of a "cold-cap" (about 1-2 hours) before switching over to pulsed feed of slurry.

${ }^{3}$ Pulsed feeding action of ADS feed pumps planned for use in the RPP-WTP was simulated by periodically opening "pinch valves" on lines from the feed re-circulation loop to the two melter feed nozzles. The feed rate was controlled by the frequency at which the pinch valves were opened. 
The Catholic University of America

Vitreous State Laboratory
DuraMelter 1200 Start-Up Tests with AZ-101

Final Report, VSL-01R0100-2, Rev.0

The melter pressure data collected during each of the three tests are displayed as frequency distributions in Figure 4.1a. The distribution is somewhat narrower for the lower-feed-rate unbubbled test (Test 1) than for the bubbled tests, probably due in part to the more complete cold cap closure for the unbubbled test. The larger excursions towards positive pressure are due to the feed pulses, as discussed above. The data in Figure 4.1a indicate that slightly lower average melter pressure is needed to maintain all excursions below ambient.

As shown the plot in Figure 4.2 shows, the computer logged melter pressure values for Test 1 are considerably scattered, likely, randomly depending on when during the feed pulse cycle the pressure was recorded. These data smoothed by averaging over five consecutive measurements are shown in the lower plot in Figure 4.2. The ten-minute time averaged melter pressure data for Test 2 and Test 3 are shown in Figure 4.3.

The water feed rate to the melter was progressively increased from $300 \mathrm{ml} / \mathrm{min}$ at the start of Test 1 to $2.81 / \mathrm{min}$ prior to the start of feeding at 3.15 hours, during which time the Paxton blower (blower \#1 in Figure 1.3) speed was progressively increased up to $95 \%$ to reduce the melter pressure below -4 in W.C. The melter pressure dropped to about -8 in W.C. following a switch from water feeding to slurry feed at 3.15 hour and was brought back to about -5 in W.C. by reducing the Paxton blower speed. A brief loss (for about $6 \mathrm{~min}$ ) in off-gas system pressure occurred at 23.4 hours, while performing maintenance on the Paxton blower, as noted in the DM1200 operations logbook.

During the first 4.35 hours of Test 2 there were problems with several channels of the off-gas data logging system were identified and no data were recorded from 3.5 to 4.2 hours, followed by another 6 minute gap in logged data at 4.3 hours. There was a sharp reduction in melter vacuum between 6 to 7 hours into Test 2 attributed to the emergency/bypass off-gas line valve tripping open, during which feeding was stopped. The valve was reset and the melter vacuum sharply increased to about -9 in W.C., followed by a brief reduction to $\sim-1$ in W.C. when feeding was resumed.

The ten-minute time-averaged melter vacuum values were relatively consistent at around -4 in W.C. during most of Test 3 with three exceptions. At approximately 26 hours, the emergency/bypass off-gas valve was again tripped while installing gas-sampling equipment. A loss of power caused the shutdown of all three blowers for about 4 minutes at 48 hours and again at 50 hours when the blowers were briefly off-line while re-setting power to the off-gas scrubber control panel and the TOC heater. 
The Catholic University of America

Vitreous State Laboratory
DuraMelter 1200 Start-Up Tests with AZ-101

Final Report, VSL-01R0100-2, Rev.0

\subsubsection{SBS Performance}

Modifications made to the SBS prior to the commissioning tests greatly reduced pressure pulsations in the melter plenum. Installation of the plate heat exchanger increased the heat removal capacity of the SBS and prevented condensation of water vapor in downstream components during high-heat-load operations, such as feeding onto a hot glass surface or when processing at high rates with bubbling.

\section{Test 1}

The SBS gas temperatures and pressures, for Test 1 are plotted in Figure 4.4. The inlet gas temperature peaked at $533^{\circ} \mathrm{C}$ at 0.9 hours. The outlet gas temperature peaked at $53^{\circ} \mathrm{C}$ at 3.1 hours, just before the start of AZ-101 surrogate feeding. Later, during the Test 1 steady-state operation period (45 to 123 hours) when the feed rate was $19.7 \mathrm{~kg} / \mathrm{hr}$, the average inlet gas temperature was $205^{\circ} \mathrm{C}$ and the average outlet temperature was at $19^{\circ} \mathrm{C}$. During this same period, the average inlet and outlet pressures were -6.2 in W.C. and -56.7 in W.C. respectively (compare with Table 4.1 listing the overall averages).

The water temperatures in the SBS, the SBS chilled water supply temperature, the cooling jacket outlet temperature, and the water outlet temperature from the plate heat exchanger recorded during Test 1 are all shown in the top plots of Figure 4.5. These data are time-averaged over 10 minutes ( 5 measurements) to reduce the scatter. There was very little difference in water temperatures measured at four depths (48, 60, 72 and 78 inches) within the SBS, and notably, even at the start of the test when feeding water to the hot melter plenum transferred steam heat to the SBS at the greatest rate. During this initial period of water feeding (increasing from $0.6 \mathrm{l} / \mathrm{min}$ at 0 hours to $2.8 \mathrm{l} / \mathrm{min}$ at 2.65 hours), the water in the SBS was heated to a maximum temperature of $\sim 55^{\circ} \mathrm{C}$. Feed was switched from water to AZ-101 surrogate feed at 3.15 hours. During the first 30 hours after the start of AZ-101 surrogate feeding, the feed rate averaged $70.6 \mathrm{~kg} / \mathrm{hr}$ and the SBS water temperature dropped to a steady-state value of $\sim 25^{\circ} \mathrm{C}$. After about 40 hours, the feeding rate was reduced to an average rate of $19.7 \mathrm{~kg} / \mathrm{hr}$ for the remainder of Test 1 . The steady-state SBS water temperature during this later period averaged $17.7^{\circ} \mathrm{C}$.

The amount of heat removed by the SBS jacket cooling water and the plate heat exchanger is shown in the lower plots of Figure 4.5 along with the cumulative feed weight. The plotted heat data are calculated based on 10 minute time-averaged cooling water temperature increases (outlet temperature minus supply temperature) across cooling jacket and plate heat exchanger multiplied by the average flow rate through each. The average flow through the jacket was $40.6 \mathrm{gpm}$ and the average cooling water flow through the plate heat exchanger was $47.1 \mathrm{gpm}$. The heat removed by the plate heat exchanger during Test 1 peaked at $248 \mathrm{~kW}$ at 2.7 hours. The heat removed by the jacket 
peaked at $69 \mathrm{~kW}$ at 2.6 hours. From 12 to 32 hours during the steady state, $70.6 \mathrm{~kg} / \mathrm{hr}$ feeding rate period, the heat removal averaged $73.6 \mathrm{~kW}$ for the plate heat exchanger and $16.4 \mathrm{~kW}$ for the jacket. During the later part of Test 1 at the steady-state feed rate of $19.7 \mathrm{~kg} / \mathrm{hr}$ (after 44 hours), heat removal averages were, respectively, 36.7 and $7.5 \mathrm{~kW}$. Throughout Test 1 , about $80 \%$ of the total heat load to the SBS was removed by the plate heat exchanger and about $20 \%$ by the jacket.

During the $19.7 \mathrm{~kg} / \mathrm{hr}$ average feed rate period, assuming the feed water content to be $52 \%$ by weight, $\sim 10.2 \mathrm{~kg} / \mathrm{hr}$ of steam was introduced into the SBS. Using the VERT thermodynamic properties database [22], the enthalpy change during steam quenching from the $205^{\circ} \mathrm{C} \mathrm{SBS}$ inlet temperature to the $19^{\circ} \mathrm{C} \mathrm{SBS}$ outlet temperature is $14.05 \mathrm{kWh} / \mathrm{kg}$-mole. Consequently, $\sim 8.0 \mathrm{~kW}$ of the overall $44.2 \mathrm{~kW}$ of heat removed by the jacket and plate heat exchanger (or about $18 \%$ ) relates to steam condensation.

\section{Test 2}

The SBS temperatures and pressures are plotted in Figure 4.6. The SBS temperature data logged during the first 4.4 hours of the test were rejected as a result of system debugging problems. During the steady-state operation (10 to 50 hours), the average inlet and outlet gas temperatures were $259^{\circ} \mathrm{C}$ and $28.3^{\circ} \mathrm{C}$, respectively. During this same period, the SBS inlet and outlet pressures averaged -6.6 and -57.6 in W.C.

SBS thermal data for the Test 2 along with cumulative feed weight are shown in Figure 4.7. The average feed rate with the melt pool agitated by bubbling was $100 \mathrm{~kg} / \mathrm{hr}$, or about 5 times the steady-state processing rate observed with the same 570 g-oxide/ 1 feed with no bubbling during Test 1. For the 10 to 50 hour period, the SBS water temperature averaged about $28^{\circ} \mathrm{C}$ with little difference between the four thermocouples located at the 48 to 78 inch levels. The average heat removed by the plate heat exchanger during this period was $90 \mathrm{~kW}$, versus $21.5 \mathrm{~kW}$ removed by the cooling jacket during the same period. Again, $\sim 80 \%$ of the total heat load was removed through the plate heat exchanger.

For the average $100 \mathrm{~kg} / \mathrm{hr}$ of feed containing $52 \%$ water, the steam input to the SBS was $\sim 52 \mathrm{~kg} / \mathrm{hr}$. From the VERT database, the enthalpy change between the $259{ }^{\circ} \mathrm{C}$ SBS inlet temperature and the $28^{\circ} \mathrm{C} \mathrm{SBS}$ outlet temperature was $14.4 \mathrm{kWh} / \mathrm{kg}$-mole. Thus, $\sim 41.6 \mathrm{~kW}$ of the total $111.5 \mathrm{~kW}$ of heat exchanged (or about $37 \%$ ) can be attributed to the condensation of steam.

\section{Test 3}


The Catholic University of America

Vitreous State Laboratory
DuraMelter 1200 Start-Up Tests with AZ-101

Final Report, VSL-01R0100-2, Rev.0

The experimental data for this test are shown in Figures 4.8 and 4.9 in a manner similar to the two preceding cases. Inlet and outlet gas temperatures reached their respective peaks at $518^{\circ} \mathrm{C}$ (at 0.7 hours) and at $55^{\circ} \mathrm{C}$ (at 1.9 hours), just before the $\mathrm{AZ}-101$ surrogate feeding was initiated. During the steady-state period ( 10 to 50 hours), the inlet and outlet gas temperatures were $275^{\circ} \mathrm{C}$ and $33.7^{\circ} \mathrm{C}$ on average. During this same period, the respective inlet and outlet average pressures were -6.3 and -58.1 in W.C. During the initial water-feeding period (increasing from 1.5 to $3.01 / \mathrm{min}$ over 1.5 hours), the liquid temperature within the SBS rose to a maximum of $57^{\circ} \mathrm{C}$ at 1.9 hours into the operation.

As expected, the greatest steady-state heat loads to the SBS occurred during Test 3 . Within the 10 to 50 hour steady-state period, the average SBS water temperature was $33.7^{\circ} \mathrm{C}$ with little deviation between the thermocouples located at different levels. The average amount of heat removed by the plate heat exchanger during this period was $122 \mathrm{~kW}$, versus $33.7 \mathrm{~kW}$ removed by the jacket cooling during the same period ( $\sim 80 \%$ through the plate heat exchanger).

In this test $\sim 86 \mathrm{~kg} / \mathrm{hr}$ of steam (average $\sim 128 \mathrm{~kg} / \mathrm{hr}$ of feed containing $67 \%$ water) entered the SBS. Since the enthalpy of quenching steam from the $275^{\circ} \mathrm{C}$ SBS inlet temperature to the 33.7 ${ }^{\circ} \mathrm{C}$ SBS outlet temperature is $14.44 \mathrm{kWh} / \mathrm{kg}$-mole, $\sim 69 \mathrm{~kW}$ of the $155.7 \mathrm{~kW}$ of the total heat exchanged in the SBS (or about $44 \%$ ) is due to steam condensation.

\section{Post-Test SBS Inspection}

After completion of these tests, the SBS sump materials were left undisturbed for about three days. The contents $(\sim 500$ gal) were then drained without difficulty using a side drain pipe/suction wand combination. The deposits accumulated in the SBS bottom and a view up from the bottom towards the diffuser plate showing the down-comer extension and weir tubes, are shown in Figure 4.10. The sump material appeared to be very well suspended and had not appreciably clarified over that period of time. Removal of the bottom dish of the SBS revealed a thin layer of deposits ( $\sim 2$ inches at the center), centrally arranged in a square pattern, which is the typical pattern formed when the mixing jets are operated continuously. The deposited material was collected weighed, assayed for water content, and analyzed. The total mass of (wet) material was $6.39 \mathrm{~kg}$ and the water content was $35.1 \mathrm{wt} \%$ (by drying to a constant weight at $105^{\circ} \mathrm{C}$ ). The material was soft and resuspended easily. The upper internals of the SBS appeared clean and smooth with no visible deposits other than a thin coating of dust.

Post-test inspection also revealed no significant deposits in the transition line downstream of the film cooler. The pipe walls remained clean and smooth. Any crevices, however, along the

transition line (such as between gasketed flange lips or within expansion joint corrugations) were 
tightly packed with a fine, powdery material making the surface flush with the pipe walls. This, in effect, rendered the entire transition line a smooth channel.

\subsubsection{WESP Performance}

The data recorded by the computerized data acquisition system for the WESP were differential pressure across WESP along with inlet and outlet gas temperatures.

\section{Test 1}

The WESP inlet and outlet gas temperatures and the differential pressure across the WESP during Test 1 are plotted in Figure 4.11. During the steady-state period while feeding at $19.7 \mathrm{~kg} / \mathrm{hr}$ (44 to 123 hours), the respective WESP average inlet and outlet gas temperatures were 23.3 and $30.9^{\circ} \mathrm{C}$, indicating a $7.6^{\circ} \mathrm{C}$ temperature increase across the WESP during this period. The pressure differential across the WESP measured a steady $1.61 \pm 0.14$ in W.C.

\section{Test 2}

The WESP inlet and outlet gas temperatures and the differential pressure across the WESP during Test 2 are plotted in Figure 4.12. During the steady-state period while feeding at $100 \mathrm{~kg} / \mathrm{hr}$ (10 to 50 hours), the respective WESP average inlet and outlet gas temperatures were 29.8 and $36.5^{\circ} \mathrm{C}$, indicating a $6.7^{\circ} \mathrm{C}$ temperature increase across the WESP during this period. The pressure differential across the WESP measured a steady $1.72 \pm 0.17$ in W.C.

\section{Test 3}

The WESP inlet and outlet gas temperatures and the differential pressure across the WESP during Test 3 are plotted in Figure 4.13. During the steady-state period while feeding at $128 \mathrm{~kg} / \mathrm{hr}$ (10 to 50 hours), the respective WESP average inlet and outlet gas temperatures were 33.9 and $39.1{ }^{\circ} \mathrm{C}$, indicating a $5.2^{\circ} \mathrm{C}$ temperature increase across the WESP during this period. The pressure differential across the WESP measured a steady $1.61 \pm 0.25$ in W.C. Notably, the differential pressure across WESP increased (see Figure 4.13 ) for $\sim 2$ hours starting at 25.5 hours, during which time the Paxton blower power was increased to $95 \%$, then to $97 \%$, while off-gas sampling equipment was being installed.

The WESP inlet temperature data appear to correlate with the SBS outlet temperature data if 
The Catholic University of America

Vitreous State Laboratory
DuraMelter 1200 Start-Up Tests with AZ-101

Final Report, VSL-01R0100-2, Rev.0

a warm ambient temperature (e.g. $\sim 35^{\circ} \mathrm{C}$ ) is assumed around the line between the two units. During the Test 1 steady-state period, gas leaving the SBS at $\sim 19^{\circ} \mathrm{C}$ warmed up by $\sim 4.3^{\circ} \mathrm{C}$ while flowing from the SBS to the WESP. During Test 2 this temperature increase was smaller, only $\sim 1.5^{\circ} \mathrm{C}$ from $28.3{ }^{\circ} \mathrm{C}$ at the SBS outlet. It was smaller yet during the Test 3 - only $0.2{ }^{\circ} \mathrm{C}$.

\section{WESP Electrical Data}

Current-voltage (I-V) data at various flow rates shown in Table 4.2 were obtained for the baseline WESP operation. Data for gas moisture contents of up to $23 \%$ (dew point of $61^{\circ} \mathrm{C}$ ) showed no abnormalities. The WESP design cut-off current of $20 \mathrm{~mA}$ was reached between 26 and $29 \mathrm{kV}$ suggesting no dielectric breakdown beyond corona discharge. At high dew-points $\left(50^{\circ} \mathrm{C}\right.$ and above) condensation was observed. However, no appreciable condensation was observed at low dew points $\left(25\right.$ to $\left.30^{\circ} \mathrm{C}\right)$.

During processing of the AZ-101 feed, the WESP current was maintained at $17 \pm 1 \mathrm{~mA}$ at 22 to $26 \mathrm{kV}$. Accumulation of liquid in the WESP sump was very slow: about 14 gallons over 10,500 $\mathrm{kg}$ of glass, most of which accumulated during the first $700 \mathrm{~kg}$ of glass when the SBS sump was operated at higher temperature.

The gas temperature rise while flowing through WESP can be clearly attributed to resistance heating. For example, considering that $\sim 0.41 \mathrm{~kW}$ of power is being dissipated within WESP operating at $24 \mathrm{kV}$ and $17 \mathrm{~mA}$ and that the heat capacity of moist air saturated at $30^{\circ} \mathrm{C}$ and flowing at rate of $200 \mathrm{cfm}$ equals to $\sim 0.12 \mathrm{~kW} / \mathrm{K}$, a temperature rise of $3.4{ }^{\circ} \mathrm{C}$ may be expected, in reasonable agreement with actual observations.

\section{Post-Test WESP Inspection}

The inside of the WESP was examined twice during these tests. The first inspection occurred after about $2100 \mathrm{~kg}$ of feed was processed (about $700 \mathrm{~kg}$ of glass made). No significant accumulation of materials was then observed on the anode except for a strongly adhered reddish coloration extending less than 1 foot towards the downstream section of the 5-foot long collector assembly. The WESP was examined a second time at the conclusion of all three tests (after 10,500 $\mathrm{kg}$ of glass was produced). The second visual inspection revealed substantial deposits extending upwards along the entire length of collectors (both the cathode and the anode) with varying thickness of $\frac{1}{8}$ to $\frac{1}{2}$ inch. A 40 -gallon water deluge was effective in washing down these deposits. Figure 4.14 shows the WESP internals before and after the wash, as well as washed-down deposits in the sump. 
The Catholic University of America

Vitreous State Laboratory
DuraMelter 1200 Start-Up Tests with AZ-101

Final Report, VSL-01R0100-2, Rev.0

\subsubsection{HEME and HEPA Filters}

The gas exiting the WESP flows through a Paxton blower (Blower \#1) followed by a high efficiency mist eliminator (HEME \#1), an in-line heater, and the first HEPA filter (HEPA \#1). The purpose of the HEME is to trap any mist entrained in saturated gas leaving WESP. The purpose of the heater is to protect the HEPA from condensation. The outlet temperature and the pressure differential across HEPA \#1 were the only two parameters monitored by the off-gas data acquisition system between the WESP and the Packed Bed Scrubber (PBS). Data recorded during Tests 1, 2 and 3 are plotted in Figures 4.15, 4.16 and 4.17. The outlet temperature at HEPA \#1 averaged 122.6 ${ }^{\circ} \mathrm{C}$ during all three tests with very little variation. The differential pressure was steady at $0.21 \pm 0.01$ in W.C. These results indicate that no significant particulate loading or moisture blinding of HEPA $\# 1$ occurred.

\subsubsection{Packed Bed Scrubber (PBS)}

Following HEPA \#1 is, in order: a second blower, a control damper, and a PBS intended to remove soluble acidic gases such as $\mathrm{HF}, \mathrm{HCl}$ and $\mathrm{SO}_{\mathrm{x}}$ from the off-gas stream. The scrubber includes a $\mathrm{pH}$-controlled caustic addition system and appropriate effluent management plumbing. However, the system was not active for the duration of the commissioning tests and only the gas inlet temperature was logged by the data acquisition system. These data are plotted in Figures 4.18, 4.19 and 4.20. These figures also show the $\mathrm{pH}$ values measured in the neutralization tank, discussed below.

\subsubsection{Effluent Liquid Treatment System}

Effluent liquids from the SBS, WESP, HEME \#1, PBS, and HEME \#2 (downstream of the PBS) are all transferred to a series of separate sampling tanks that discharge into three 500gallon tanks for neutralization, mixing, and storage. The largest effluent volume is generated by the overflow from the SBS, which is initially pumped to one of the two SBS sampling tanks. Caustic solution $(25-30 \% \mathrm{NaOH})$ from the same caustic container that supplies the PBS can also be added to the 500-gallon tank that receives acidic effluents from the sampling tanks. Effluents collected in the storage tank can be periodically transferred to the integral Landa Evaporator for concentration and either recycle or disposal. The Landa evaporator is periodically opened for removal of salt residues from evaporation.

The various effluent liquid sampling and storage tanks are visually monitored during periodic rounds and effluent liquid transfers are made as needed. The only parameter of the effluent liquid treatment system monitored by the computerized data acquisition system during the commissioning 
The Catholic University of America

Vitreous State Laboratory
DuraMelter 1200 Start-Up Tests with AZ-101

Final Report, VSL-01R0100-2, Rev.0

tests was the $\mathrm{pH}$ of the neutralization tank. As shown in Figure 4.18, a caustic addition was made to the neutralization tank early in Test 1 , just before melter feeding was started at 2.5 hours, increasing the $\mathrm{pH}$ of the tank contents from $\sim 7.2$ to greater than 10 . At that time, there was a limitation in the data acquisition system that precluded recording of $\mathrm{pH}$ values above 10 . After 26 hours, a sufficient amount of acidic effluent had been transferred to the neutralization tank to bring the $\mathrm{pH}$ below 10 , after which, actual $\mathrm{pH}$ data were recorded. Step changes and spikes in the plotted $\mathrm{pH}$ data generally correspond to effluent liquid transfers and caustic additions to the neutralization tank.

\subsubsection{Thermal Catalytic Oxidation Unit}

HEME\#2 and the Thermal Catalytic Oxidation (TCO) unit follow the PBS in the off-gas treatment system. The HEME removes any aerosols that may be carried over from the scrubber. The TCO unit is equipped with an $80 \mathrm{~kW}$ heater at the front end to appropriately condition the incoming gas. No catalyst was installed in the TCO, which was therefore not active during commissioning tests. However, the TCO heater was utilized to prevent condensation within the building stack.

The gas temperature exiting the TCO was logged by the data acquisition computer and is plotted for all three test runs in Figure 4.21. The TCO outlet temperature averaged about $73{ }^{\circ} \mathrm{C}$ during all tests. The TCO heater was turned on shortly after the start of Test 3 , as is evident in the TCO outlet temperature data plotted in Figure 4.21. A momentary power loss at hour 48 of Test 3 caused the TCO heater to trip. Power to the heater was reset after two hours and the TCO outlet gas temperature returned to its normal operating value of $\sim 77^{\circ} \mathrm{C}$.

\subsection{Effluent Fluids}

\subsubsection{SBS Fluids}

One-liter aliquots were taken from the SBS and WESP each time liquids were blown down from the main reservoir and at the end of each test. Samples were subjected to total dissolved solids (TDS) and total suspended solids (TSS) determinations by gravimetric analysis of filtered material and the evaporated filtrate. Additional sample was filtered to generate solids and filtrate for complete chemical analysis, which included $\mathrm{pH}$ determination, direct current plasma emission spectroscopy (DCP) analysis for metals, atomic absorption (AA) for cesium, and ion chromatography for anions; the dried filtered solids underwent microwave assisted acid dissolution prior to chemical analysis. The acids $\left(\mathrm{HF}\right.$ and $\left.\mathrm{HNO}_{3}\right)$ required to dissolve the filtered solids prevented analysis of all anions except sulfate and iodide.

All of the SBS and WESP sump samples that were taken throughout the DM1200 
The Catholic University of America

Vitreous State Laboratory
DuraMelter 1200 Start-Up Tests with AZ-101

Final Report, VSL-01R0100-2, Rev.0

commissioning tests are listed in Table 4.3; the middle letter in the sample name is "S" for the SBS samples and "W" for the WESP samples. Table 4.3 shows the TSS, TDS, and $\mathrm{pH}$ values for each sample, as well as the amount of glass that had been produced at the time the sample was taken. Also shown in Table 4.3 is the blow-down volume from which each SBS sample was taken and the cumulative SBS blow-down volume; the WESP was not blown down during these tests. The volume of the SBS sump is about 500 gallons. At the end of Test 2, a 55-gallon drum of the SBS sump liquid was collected and shipped to SRTC for use in recycle stream mixing tests and pretreatment testing.

The TSS, TDS, and $\mathrm{pH}$ values for the SBS liquids are plotted in Figure 4.22. The average values for the SBS liquid TSS and TDS values were $450 \mathrm{mg} / 1$ and $1550 \mathrm{mg} / 1$, respectively, and the values over the course of these tests do not vary widely from these averages (Figure 4.22). Conversely, the $\mathrm{pH}$ values were stable at around $\mathrm{pH} 3$ until the last test (high water), during which the $\mathrm{pH}$ quickly rose to an average of about $\mathrm{pH} 3.6$ over the course of that test. The $\mathrm{pH}$ rise is probably a dilution effect due to the increased feed water content ( $67 \mathrm{vs} 52 \mathrm{wt}$ \%) used in the last test.

Figure 4.23 compares the amount of water fed to the total volumetric accumulations in the SBS over the course of the post-turnover tests. The close agreement between these quantities indicates that nearly all of the feed water is condensed in the SBS as a result of its low operating temperature. Water was fed to the melter at the beginning of each test to create a cold cap and thereby minimize subsequent off-gas surges due to pulsed feeding onto bare glass (this is the same feed start-up protocol used at West Valley.) Consequently, the accumulation in the SBS is slightly greater than the amount of water that was introduced as part of the slurry feed.

Chemical analysis results for the SBS samples are provided in Table 4.4. Figure 4.24 compares the SBS dissolved and suspended fractions (sample 12D-S-116A) with the composition of the feed. As might be expected, the dissolved solids consist mainly of species such as alkali metals, halogens, boron, nitrate, and sulfate, as well as significant amount of selenium. These constituents are also relatively volatile. The suspended solids consist primarily of iron and silicon with significant amounts of selenium, tellurium, nickel, lead, chromium, and zirconium. Other metals such as aluminum, calcium, magnesium, cadmium, manganese, and zinc are present in comparable amounts in both the suspended and dissolved fractions of the SBS samples ${ }^{4}$. Iodide was not present in the feed during the turnover segment but was present for all three post-turnover tests. Accordingly, there is a significant increase in the iodide concentration with the first sample from Test 1 (12D-S-115A, see Table 4.4), all of which is present in the dissolved fraction.

\footnotetext{
${ }^{4}$ It should be noted that the filter pore size mandated by the standard methods that were used is 1.5 micron and therefore any particles less than this size could have contributed to the "dissolved" fraction instead of the suspended fraction.
} 
The Catholic University of America

Vitreous State Laboratory
DuraMelter 1200 Start-Up Tests with AZ-101

Final Report, VSL-01R0100-2, Rev.0

A thermodynamic database and geochemical speciation code (EQ3/6, [23]) was used to calculate the $\mathrm{pH}$ of the SBS solution from the chemical analysis and to determine the speciation of the constituents in the solution. The $\mathrm{pH}$ agreed well with the measured value; a summary of the calculated speciation results is presented in Table 4.5. The code also calculates mineral phase saturation indices, which can be compared with the dissolved solids fraction.

The accumulations of elements in the SBS solutions over the course of the tests are depicted in Figures 4.25-28. The elemental accumulations coincide with the accumulation of water (Figure 4.23), as expected given the relative consistency of total suspended and dissolved solids over the course of the tests (Figure 4.22). Over two kilograms of both selenium and sulfate accumulated over the course of the tests as well as tens of grams of metals such as cadmium, nickel, lead, and arsenic. Significant accumulations of cesium and iodide in the SBS effluents were also apparent.

\subsubsection{WESP Fluids}

Results from the analysis of WESP samples are provided in Table 4.6 and indicate that the majority of the coarser, less-soluble species were removed by the SBS leaving only highly soluble species. Notice that the concentrations of dissolved species in the WESP typically exceed the corresponding values in the SBS by greater than an order of magnitude. Conversely, the suspended solid concentration is substantially lower than that in the SBS. The WESP solutions are high in alkali metals, halides, boron, selenium, and sulfate and show significant enrichment over the SBS in arsenic, cadmium, and chromium, as depicted in Figure 4.29. These observations are generally consistent with the enhanced capture by the WESP of smaller particulates formed by the more volatile species, as is intended in the off-gas system design. However, the small volume of solution in the WESP at the end of the commissioning tests (a total of 14 gallons and no blow down) results in the WESP not being a significant factor with respect to elemental mass balances. In addition, as a consequence of the WESP not being blown down during or between tests, most elemental concentrations increased over the course of these tests. 
The Catholic University of America

Vitreous State Laboratory
DuraMelter 1200 Start-Up Tests with AZ-101

Final Report, VSL-01R0100-2, Rev.0

\section{SECTION 5.0 GLASS PRODUCT}

Over $10,000 \mathrm{~kg}$ of glass product was discharged from the melter using an airlift system into 55-gallon drums. The discharged product glass was sampled at the end of each test by removing sufficient glass from the top of the drums for total inorganic analysis and TCLP testing. Product glass masses, discharge date, and the analyses performed for discharges during Tests 1 through 3 are listed in Table 5.1.

\subsection{Compositional Analysis}

Glass samples were crushed and either dissolved in $\mathrm{HF} / \mathrm{HNO}_{3}$ acid mixtures with the aid of a microwave oven to produce a solution for DCP analysis or analyzed directly by XRF. Boron and lithium oxide concentrations derived from the DCP procedure were used for normalizing the XRF data since those elements were not determined by XRF. Digested glass samples were also analyzed for cesium using flame atomic absorption. Analyzed glass compositions are provided in Table 5.2 for discharged samples, using both methods. Compositional trends over the course of the tests are plotted for selected elements in Figures 5.1 - 5.4. The results are similar to those for the feed samples given in Table 2.5. Generally, there was good agreement with the target composition for the major oxides except for $\mathrm{Li}_{2} \mathrm{O}$ (about $15 \%$ below target) and $\mathrm{XRF}$ analysis of $\mathrm{ZrO}_{2}$ (about $25 \%$ above target). Some of the minor oxides, targeted at less than $0.5 \mathrm{wt} \%$, such as $\mathrm{CaO}$ and $\mathrm{K}_{2} \mathrm{O}$, were consistently above target, sometimes by as much as a factor of two. This is probably due to impurities in the raw materials. Unlike the feed samples that were vitrified via crucible melting, more of the volatile minor elements were retained in the glass product from the melter tests. As expected, selenium glass concentrations are well below target due to volatilization ranging from 7 to 50 percent (see Section 6). Results from the different methods of analyses agree well for the vast majority of elements, as was the case for feed sample analysis. Silicon analyses using XRF are always higher and closer to target than the DCP analysis, presumably as a consequence of the dissolution step used for DCP analysis.

\subsection{Chemical Durability}

A sample of the glass product was subjected to the EPA TCLP leach test (SW-846 Method 1311). In that procedure, a leachate solution is extracted from crushed glass with a sodium acetate buffer solution for 18 hours at $22^{\circ} \mathrm{C}$ with constant end-over-end agitation. The leachate concentrations were then measured by direct current plasma atomic emission spectroscopy (DCP- 
The Catholic University of America

Vitreous State Laboratory
DuraMelter 1200 Start-Up Tests with AZ-101

Final Report, VSL-01R0100-2, Rev.0

AES). The test results and the Universal Treatment Standard (UTS) limits are given in Table 5.3. The measured leachate concentrations were all lower than the regulatory limits and, for many analytes, one to two orders of magnitude lower than the limits. Cadmium values, although below the UTS limit, came closest to the limit. Although the value for barium is still more than 35 times less than the UTS limit, the value of $0.58 \mathrm{ppm}$ is appears to be high given the low concentration of $0.04 \mathrm{wt} \%$ targeted in the glass product and in comparison to the earlier results. 
The Catholic University of America

Vitreous State Laboratory
DuraMelter 1200 Start-Up Tests with AZ-101

Final Report, VSL-01R0100-2, Rev.0

\section{SECTION 6.0 \\ MONITORED OFF-GAS EMISSIONS}

\subsection{Particulate and Gaseous Emissions}

Eleven exhaust samples were taken from the melter and various off-gas system components according to 40-CFR-60 Methods 3, 5, and 29 to examine particulate and certain gaseous fluxes. The majority of the off-gas analyte concentrations were derived from laboratory data on solutions extracted from air samples (filters and various solutions) together with measurements of the volume of air sampled. The volume of air sampled and the rate at which it can be sampled are defined in 40CFR-60 and SW-846. Isokinetic sampling, which entails removing gas from the exhaust at the same velocity that the air is flowing in the duct (40-CFR-60, Methods 1-5), was used. Typically, a sample size of $30 \mathrm{dscf}$ is taken at a rate of between 0.5 and $0.75 \mathrm{dscfm}$. Total particulate loading was determined by gravimetric analysis of the standard particle filter and of probe-rinse solutions. Down stream of the particulate filter in the sampling train are iced impingers with acidic $(5 \%$ concentrated nitric acid plus $10 \%$ hydrogen peroxide $)$ and basic $(0.1 \mathrm{~N}$ sodium hydroxide $)$ solutions. The analysis of these solutions permits the determination of total gaseous emissions of several elements, notably halides and sulfur.

Results from exhaust sampling and analysis are compared to feed fluxes in Tables 6.1-6.4, which also list the calculated decontamination factors (DFs) across the melter and the SBS. Solids carry-over from the melter was minimal during these tests, never exceeding $0.27 \%$ of feed solids. As expected, the particulate emissions, both as flux and percent of feed, are far lower in Test 1 than in Tests 2 and 3 due to the lack of bubbling in Test 1; DFs across the melter for total solids were around 400 with bubbling and around 2000 without bubbling. The composition of the particles is similar to that observed in previous studies [1,9]: high in volatile species such as boron, selenium, sulfur, and alkali, with lower concentrations of all other feed constituents. Impinger solutions were analyzed for the all of the elements in the feed but only the halides, sulfur, selenium, and boron were detected, with the exception of the Test 3 melter exhaust sample. The prescience of these elements in the gas fraction is consistent with observations from previous studies [1,9]. The small amount of chlorine in the feed ( $0.01 \mathrm{wt} . \%$ in the target glass) and the ubiquity of chloride as a trace level contaminant in water and the raw materials used for the feed explain the occurrences of gaseous chlorine emissions exceeding the recipe feed fluxes. The impinger solution, probe rinse, and filter chemical analysis for the Test 3 melter exhaust sample were very similar indicating a filter breach. Since a distinction could not reasonably be made between the particle and gaseous species in this sample, composite values for each element are provided in Table 6.4. 
The Catholic University of America

Vitreous State Laboratory
DuraMelter 1200 Start-Up Tests with AZ-101

Final Report, VSL-01R0100-2, Rev.0

DFs across the SBS for total particulate ranged from about 2 to 77 and were higher for the bubbled tests, for which the particulate flux from the melter was higher. Elemental DFs across the SBS tended to be lower for the more volatile feed constituents, which would be expected to form the majority of the finer particulate matter.

Iodine was detected in significant quantities in samples taken at all three locations. Iodine was only detected in the impinger solution downstream of the particle filter, indicating that it was exclusively gaseous. Furthermore, greater than $90 \%$ of all the iodine detected was measured in the basic impinger $(0.1 \mathrm{~N} \mathrm{NaOH})$ down stream of the two acidic impingers $(5 \%$ nitric acid and $10 \%$ hydrogen peroxide). Although this may not clearly indicate which gaseous form the iodine takes, it does indicate that acidic scrubbing solutions in the off-gas system will not remove significant amounts of iodine. This is corroborated by the large iodine fluxes detected in samples taken down stream of the WESP (100-200 $\mathrm{mg} / \mathrm{min}$ or up to $77 \%$ of feed iodine) and that only $11.1 \%$ of feed iodine accumulated in the SBS (Table 6.5). Iodine emissions were highly variable ranging from 17 to $95 \%$ with no clear trend with respect to melter operating conditions or sampling location. This variability coupled with the lack of iodine detected in the glass product result in variable mass balance closure with respect to feed iodine.

\subsection{Particle Size Distribution}

Samples were also taken using a University of Washington cascade impactor, which separates particles into particle size ranges enabling the determination of particle size distributions. The melter, SBS, and WESP exhaust streams were sampled during each test. Data for the particle size distributions are provided in Tables 6.6 and 6.7. The chemical compositions of each particle size fraction emitted from the melter are provided in Table 6.8 and 6.9. Enough material was collected on filters from the melter and SBS exhaust to determine size distributions; however, sufficient material for chemical analysis was only collected on melter exhaust samples from Tests 2 and 3 . The particulate concentration in the WESP exhaust was insufficient for accurately determining particle size distributions and therefore no results are reported here. However, the results from these initial tests were used as the basis for optimization of off-gas sample collection durations for subsequent tests, from which particle size distributions for the WESP outlet stream have been successfully determined [6].

Particle emissions from the SBS were mainly sub-micron in size, whereas melter emissions

were more evenly distributed across the size spectrum. This is consistent with the design intent of the SBS, which is primarily to remove the larger particulate, leaving removal of the finer particulate to the WESP, which is much better suited to that function. The composition of the particles emitted 
The Catholic University of America

Vitreous State Laboratory
DuraMelter 1200 Start-Up Tests with AZ-101

Final Report, VSL-01R0100-2, Rev.0

from the melter varied with size as shown in Tables 6.8 and 6.9. Notice the increases in mass percent for $\mathrm{Cd}, \mathrm{Cs}, \mathrm{K}, \mathrm{S}$, and Te with decreasing particle size whereas elemental mass percentages of Al, B, $\mathrm{Mn}, \mathrm{Si}, \mathrm{Sr}, \mathrm{Zn}$ and $\mathrm{Zr}$ decrease with decreasing particle size. Sodium and selenium are common in all size fractions and show some tendency towards the smaller fractions. Comparison of SBS and WESP sump analysis (Tables 4.4 and 4.5 ) with the chemical analysis by particle size is consistent with the expectation of smaller water-soluble particles accumulating in the WESP, whereas coarser insoluble species tend to accumulate in the SBS.

\subsection{FTIR Analysis}

Off-gas analysis by Fourier Transform Infra-Red (FTIR) spectroscopy was performed using an On-Line Technologies Inc. Model 2010 Multi-Gas ${ }^{\mathrm{TM}}$ Analyzer. Data were recorded at $71 \mathrm{~s}$ intervals, corresponding to an average of 128 scans at $0.5 \mathrm{~cm}^{-1}$ spectral resolution. The melter offgas supplied to the FTIR spectrometer was extracted using a sampling and transfer loop, which removed a gas sample stream from the off-gas system at 5 liters per minute. The sampling and transfer loop was maintained at $150^{\circ} \mathrm{C}$ throughout in order to prevent analyte loss due to condensation.

Melter off-gas emissions were monitored by FTIR spectroscopy during each test for a set of selected species over discrete time intervals at specified off-gas system locations. Table 6.10 displays a summary of the average analyte concentrations measured over the course of each test. Real-time concentration run data are presented in Figures 6.1-6.3 for most of the nitrogen-bearing species monitored over the three tests. As expected, $\mathrm{NO}$ and $\mathrm{NO}_{2}$ were observed at the highest concentrations among the nitrogen-bearing analytes. In general throughout Tests 1 - 3, NO was detected at concentrations five to fifteen times higher than those of $\mathrm{NO}_{2}$ and significantly higher than those of the other nitrogen-bearing analytes. The observation of increased concentrations of $\mathrm{NO}_{\mathrm{X}}$ analytes in Tests 2 and 3 compared to Test 1, by approximately a factor of two, is consistent with the increased feed rates used in the later tests. Other than the $\mathrm{NO}_{\mathrm{X}}$ analytes, $\mathrm{H}_{2} \mathrm{O}$ and $\mathrm{CO}_{2}$, the remaining analytes were detected at rather low concentrations, typically less than $1 \mathrm{ppm}$. $\mathrm{HF}, \mathrm{HCl}$, and $\mathrm{SO}_{2}$ were observed at slightly higher concentrations in Tests 2 and 3 , presumably due to the increased feed rates, at the melter outlet port but were effectively removed from the off-gas emissions by the SBS unit. Nitrogen mass balances over Tests $1-3$ are shown in Table 6.11 and Figures 6.4-6 for the predominant $\mathrm{NO}_{\mathrm{X}}$ species $\left(\mathrm{NO}\right.$ and $\mathrm{NO}_{2}$ ) compared to feed nitrogen. Although feed nitrogen can only account for $\sim 60 \%$ of combined $\mathrm{NO}$ and $\mathrm{NO}_{2}$ emissions, this observation is likely related to the low feed concentrations and the influence that low levels of contamination would therefore exert. 


\section{SECTION 7.0 SUMMARY AND CONCLUSIONS}

A series of tests was successfully completed on the DM1200 HLW pilot melter system configured with an integrated prototypical off-gas treatment system. To our knowledge, these tests are the first in which a joule-heated waste glass melter has been operated with this particular sequence of off-gas treatment components. The general objectives of these tests related to the startup and commissioning of this new system prior to its use in subsequent vitrification development testing. It is expected that the DM1200 system will be used for testing and confirmation of basic design, operability, flow sheet, and process control assumptions as well as for support of waste form qualification and permitting. This will include data on processing rates, off-gas treatment system performance, recycle stream compositions, as well as process operability and reliability. Consequently, this system is a key component of the overall HLW vitrification development strategy. Conversely, the results presented in this report are from the initial series of short-duration tests that were conducted to support the start-up and commissioning of this system prior to conducting the main body of development tests that have been planned for this system. Accordingly, these tests were directed primarily at system "debugging," operator training, and procedure refinement.

The commissioning tests were composed of four test segments, during which, a total of $10,500 \mathrm{~kg}$ of glass was produced:

- Turnover - during which the glass inventory (about $1700 \mathrm{~kg}$ ) was turned over from the start-up frit composition to the AZ-101 glass composition. About $5000 \mathrm{~kg}$ of glass was produced during this period.

- Test 1 - High-solids feed, very low bubbling (4 scfh); 120 hours, $1587 \mathrm{~kg}$ glass produced.

- $\quad$ Test 2 - High-solids feed, with bubbling (120 scfh); 50 hours, $1948 \mathrm{~kg}$ glass produced.

- Test 3 - Low-solids feed, with bubbling (120 scfh); 50 hours, $1922 \mathrm{~kg}$ glass produced.

All of the tests were performed with the same AZ-101 waste simulant and glass composition , a nominal glass pool temperature of $1150^{\circ} \mathrm{C}$, essentially complete cold cap coverage, and a nominal plenum temperature between $400-600^{\circ} \mathrm{C}$. Side-to-side electrode firing was used (the bottom electrode was not powered) and one of the two installed feed tubes was used in order to more closely 
The Catholic University of America

Vitreous State Laboratory
DuraMelter 1200 Start-Up Tests with AZ-101

Final Report, VSL-01R0100-2, Rev.0

reflect the number of feed tubes per unit area planned for the full-scale HLW melter. Bubbling was from the bottom electrode bubblers. The high- and low-solids melter feeds had nominal glass yields of 570 and $350 \mathrm{~g} / 1$, respectively. These tests evaluated a relatively wide range of feed water contents and processing rates in order to fully exercise the off-gas treatment system.

Although several system refinements were identified and implemented during these tests, such as the need for additional SBS cooling capacity to support the higher processing rate bubbled tests and the condensation of water downstream of the SBS at the higher SBS sump temperatures, the general operating characteristics of the system were in line with the system design intent. The SBS effectively quenched the off-gas stream and removed the majority of the larger particulate, while the WESP was effective in removing the remaining finer particulate. As a result, there was no indication of increased pressure drops across either the HEMEs or the HEPAs during these tests. Other system design issues, such as the degradation of the SBS packing and the amplitude of pressure fluctuations caused by the SBS, were shown to have been effectively remedied by the approaches that were identified during the prior off-line testing of the system [11]. Although not the primary intent of these tests, the processing rates were generally consistent with earlier tests that were performed on the DM1000 system [1] with the same AZ-101 simulant and glass composition. 


\section{SECTION 8.0 \\ REFERENCES}

[1] "Determination of Processing Rate of RPP-WTP HLW Simulants using a DuraMelter"TM 1000 Vitrification System," K.S. Matlack, W.K. Kot, F. Perez-Cardenas, and I.L. Pegg, VSL-00R2590-2, Rev. 0, 8/21/00.

[2] "Commissioning and HLW Throughput Tests on the DM1200 Melter," Test Specification TSP-W375-00-00011; "DM1200 Melter Integrated Offgas Treatment System Tests," Test Specification, TSP-W375-00-00020.

[3] "Start-Up and Commissioning Tests on the DM1200 HLW Pilot Melter System Using AZ101 Waste Simulants," K.S. Matlack, M. Brandys, and I.L. Pegg, Test Plan, VSL-01T01001, Rev.1, 2/12/00.

[4] "Preliminary Data Summary Report: Start-Up and Commissioning Tests on the Duramelter ${ }^{\mathrm{TM}} 1200$ HLW Pilot Melter System Using AZ-101 HLW Simulants," K.S. Matlack, M. Brandys, and I.L. Pegg, VSL-01R100-1, 6/25/01.

[5] "Tests on the DM1200 HLW Pilot Melter System Using HLW AZ-101 Simulants," K.S. Matlack, W.K. Kot, M. Brandys, and I.L. Pegg, Test Plan, VSL-01T0100-2, Rev. 1, 5/21/01.

[6] "Data Summary Report: Tests on the DM1200 HLW Pilot Melter System Using HLW AZ101 Simulants: First Four Post-Commissioning Tests," K.S. Matlack, and I.L. Pegg, VSL01S2100-1, Rev. 0, 10/17/01.

[7] "Tests on DuraMelter ${ }^{\mathrm{TM}} 10$ with AZ-101 Simulant in Support of DuraMelter ${ }^{\mathrm{TM}} 1000$ Throughput Tests," Keith S. Matlack, Wing K. Kot, F. Perez-Cardenas, and Ian L. Pegg, VSL-00R2501-1, Rev. 0, 4/21/00.

[8] "Melter Tests with AZ-101 HLW Simulants Using DuraMelter ${ }^{\mathrm{TM}} 100$ Vitrification Systems," K.S. Matlack, W.K. Kot, and I.L. Pegg, VSL-01T10N0-1, Rev. 1, 11/30/00.

[9] "Melter Tests with AZ-101 HLW Simulants Using a DuraMelter ${ }^{\mathrm{TM}} 100$ Vitrification System," K.S. Matlack, W.K. Kot, and I.L. Pegg, VSL-01R10N0-1, Rev. 0, 8/31/01. 
[10] "Design and Installation of a Prototypical Off-Gas Treatment System for the DM1200 RPPWTP HLW Pilot Melter," R.T. Anderson, M. Brandys, and R. Jung, Final Report, VSL01R2510-1, Rev. 0, 2/22/01.

[11] "Submerged Bed Scrubber: Off-Line Component Testing of DM1200 SBS Unit," M. Brandys, R.T. Anderson, R. Jung, J. Rouse, and I.L. Pegg, Final Report, VSL-01R22001, Rev. 0, 9/21/01.

[12] "Quality Assurance Project Plan for RPP-WTP Support Activities Conducted by VSL," Vitreous State Laboratory, QAPP Rev. 3, 8/28/00.

[13] "Quality Assurance Project Plan for RPP-WTP Support Activities Conducted by VSL," Vitreous State Laboratory, QAPP Rev. 4, 8/2/2001.

[14] "Master List of Controlled VSL Manuals and Standard Operating Procedures in Use," QAMLCP, Rev. 0, August 14, 2001.

[15] "Tank Waste Remediation System Operation and Utilization Plan to Support Waste Feed Delivery," R.A. Kirkbride, G.K. Allen, R.M. Orme, R.S. Wittman, J.H. Baldwin, T.W. Crawford, J. Jo, L.J. Fergestrom, G.T. MacLean and D.L. Penwell, Volume I, HNF-SDWM-SP-012, Revision 1 (Draft), February 1999.

[16] Hanford Tank Waste Best Basis Inventory, Tank Waste Information Network System 2 (http://twins.pnl.gov:8001).

[17] "Phase I High-Level Waste Pretreatment and Feed Staging Plan," A.F. Manuel, S.L. Lambert and G.E. Stegen, WHC-SD-WM-ES-370, Revision1, September 1996.

[18] "Tank Farm Contractor Operation and Utilization Plan," R.A. Kirkbride, G.K. Allen, B.A. Highley, R.M. Orme, R.S. Wittman, J.H. Baldwin, T.W. Crawford, J. Jo, J. N. Strode, T.M. Hohl, S.L. Lambert, D.E. Place and J.A. Seidl, Volume I, HNF-SD-WM-SP-012, Revision 2, April 2000.

[19] "Calculation of Lag Storage Requirements for Phase 1 Pretreatment Operations," BNFL, Inc. Memorandum \#001753, E. Slaathaug to I. Papp, February 17, 1999.

[20] "Using $\mathrm{MnO}_{4}$ for TRU Separations," M. Johnson, E-mail message to I.L. Pegg, May 17, 1999. 
[21] "Physical and Rheological Properties of Waste Simulants and Melter Feeds for RPP-WTP Vitrification," W.K. Kot, Hao Gan and I.L. Pegg, Final Report, VSL-00R2520-1, Oct. 31, 2000 .

[22] VERT 2000 Thermodynamic Data, G. McArthur, release version 1.6, June 2000. BNFL Engineering Ltd, Richland, WA.

[23] T.J. Wolery, EQ3/6, Version 7.2b, The University of California, Lawrence Livermore National Laboratory. 
Table 1.1. Test Summary for DuraMelter 1200 AZ-101 Commissioning Tests.

\begin{tabular}{|c|c|c|c|c|}
\hline \multicolumn{2}{|l|}{ Test \# } & 1 & 2 & 3 \\
\hline \multirow[t]{3}{*}{ Time } & Feed Start & 5/7/01 10:00 & 5/14/01 09:29 & 5/21/01 08:51 \\
\hline & Feed End & $5 / 12 / 0113: 10$ & $5 / 16 / 0113: 39$ & $5 / 23 / 0113: 28$ \\
\hline & Interval & $123.2 \mathrm{hr}$ & $52.2 \mathrm{hr}$ & $52.7 \mathrm{hr}$ \\
\hline \multicolumn{2}{|c|}{ Water Feeding for Cold Cap } & $3.2 \mathrm{hr}$ & $2.6 \mathrm{hr}$ & $2.5 \mathrm{hr}$ \\
\hline \multicolumn{2}{|l|}{ Slurry Feeding } & $120.0 \mathrm{hr}$ & $49.6 \mathrm{hr}$ & $50.2 \mathrm{hr}$ \\
\hline \multicolumn{2}{|l|}{ Cold cap burn off } & $10.0 \mathrm{hr}$ & $1.2 \mathrm{hr}$ & $1.6 \mathrm{hr}$ \\
\hline \multicolumn{2}{|l|}{ Total } & $133.2 \mathrm{hr}$ & $53.4 \mathrm{hr}$ & $53.2 \mathrm{hr}$ \\
\hline \multicolumn{2}{|l|}{ Bubbling Rate } & $<8$ scfh & $120 \mathrm{scfh}$ & $120 \mathrm{scfh}$ \\
\hline \multirow{5}{*}{ Feed } & Characteristics & Nominal & Nominal & High Water \\
\hline & Used & $4178 \mathrm{~kg}$ & $4948 \mathrm{~kg}$ & $6423 \mathrm{~kg}$ \\
\hline & \multirow{2}{*}{ Glass yield ${ }^{\#}$} & $570 \mathrm{~g} / 1$ & $570 \mathrm{~g} / 1$ & $350 \mathrm{~g} / 1$ \\
\hline & & $0.380 \mathrm{~kg} / \mathrm{kg}$ & $0.380 \mathrm{~kg} / \mathrm{kg}$ & $0.275 \mathrm{~kg} / \mathrm{kg}$ \\
\hline & Average Feed Rate & $34.8 \mathrm{~kg} / \mathrm{hr}$ & $99.8 \mathrm{~kg} / \mathrm{hr}$ & $127.9 \mathrm{~kg} / \mathrm{hr}$ \\
\hline \multirow{5}{*}{ Glass Produced } & Poured & $1587 \mathrm{~kg}$ & $1948 \mathrm{~kg}$ & $1922 \mathrm{~kg}$ \\
\hline & Average Rate $\$$ & $265 \mathrm{~kg} / \mathrm{m}^{2} /$ day & $785 \mathrm{~kg} / \mathrm{m}^{2} /$ day & $766 \mathrm{~kg} / \mathrm{m}^{2} /$ day \\
\hline & Average Rate ${ }^{*}$ & $265 \mathrm{~kg} / \mathrm{m}^{2} /$ day & $759 \mathrm{~kg} / \mathrm{m}^{2} /$ day & $705 \mathrm{~kg} / \mathrm{m}^{2} /$ day \\
\hline & Steady State Rate ${ }^{*}$ & $155 \mathrm{~kg} / \mathrm{m}^{2} /$ day & $750 \mathrm{~kg} / \mathrm{m}^{2} /$ day & $700 \mathrm{~kg} / \mathrm{m}^{2} /$ day \\
\hline & Average Power Use & $9.8 \mathrm{~kW} . \mathrm{hr} / \mathrm{kg}$ glass & $3.6 \mathrm{~kW} \cdot \mathrm{hr} / \mathrm{kg}$ glass & $4.5 \mathrm{~kW} . \mathrm{hr} / \mathrm{kg}$ glass \\
\hline
\end{tabular}


Table 2.1. Composition Summary of AZ-101 Waste, LAW Pretreatment Products, AZ-101 Simulant Plus Pretreatment Products, Glass Additives, and HLW98-31 Glass.

\begin{tabular}{|c|c|c|c|c|c|}
\hline & $\begin{array}{c}\text { AZ-101 } \\
\text { Envelope D } \\
\text { Waste }\end{array}$ & $\begin{array}{c}\text { Pretreatment } \\
\text { Products (as } \\
\text { wt } \% \text { of total } \\
\text { AZ-101 oxides) }\end{array}$ & $\begin{array}{c}\text { AZ-101 } \\
\text { Simulant } \\
\text { (Envelope D }+ \\
\text { Pretreatment } \\
\text { Products) }\end{array}$ & $\begin{array}{l}\text { Additives (as } \\
\mathrm{w} t \% \text { of glass) }\end{array}$ & $\begin{array}{c}\text { HLW98-31 } \\
\text { Glass } \\
\text { Composition }\end{array}$ \\
\hline $\mathrm{Al}_{2} \mathrm{O}_{3}$ & $27.41 \%$ & & $24.27 \%$ & & $7.40 \%$ \\
\hline $\mathrm{As}_{2} \mathrm{O}_{3}$ & $0.15 \%$ & & $0.13 \%$ & & $0.04 \%$ \\
\hline $\mathrm{B}_{2} \mathrm{O}_{3}$ & & & & $10.00 \%$ & $10.00 \%$ \\
\hline $\mathrm{BaO}$ & $0.16 \%$ & & $0.14 \%$ & & $0.04 \%$ \\
\hline $\mathrm{CIO}$ & $0.91 \%$ & & $0.81 \%$ & & $0.25 \%$ \\
\hline $\mathrm{CdO}$ & $1.38 \%$ & & $1.22 \%$ & & $0.37 \%$ \\
\hline $\mathrm{CeO}_{2}$ & $0.31 \%$ & & $0.27 \%$ & & $0.08 \%$ \\
\hline $\mathrm{Cl}$ & $0.03 \%$ & & $0.02 \%$ & & $0.01 \%$ \\
\hline $\mathrm{Cr}_{2} \mathrm{O}_{3}$ & $0.16 \%$ & & $0.14 \%$ & & $0.04 \%$ \\
\hline $\mathrm{Cs}_{2} \mathrm{O}$ & $0.01 \%$ & $0.3 \%$ & $0.27 \%$ & & $0.08 \%$ \\
\hline $\mathrm{CuO}$ & $0.10 \%$ & & $0.09 \%$ & & $0.03 \%$ \\
\hline $\mathrm{F}$ & $0.14 \%$ & & $0.12 \%$ & & $0.04 \%$ \\
\hline $\mathrm{Fe}_{2} \mathrm{O}_{3}$ & $38.49 \%$ & & $34.08 \%$ & & $10.39 \%$ \\
\hline $\mathrm{K}_{2} \mathrm{O}$ & $0.63 \%$ & & $0.55 \%$ & & $0.17 \%$ \\
\hline $\mathrm{La}_{2} \mathrm{O}_{3}$ & $1.20 \%$ & & $1.06 \%$ & & $0.32 \%$ \\
\hline $\mathrm{Li}_{2} \mathrm{O}$ & & & & $6.00 \%$ & $6.00 \%$ \\
\hline $\mathrm{MgO}$ & $0.24 \%$ & & $0.21 \%$ & & $0.06 \%$ \\
\hline $\mathrm{MnO}$ & $7.76 \%$ & $3.5 \%$ & $9.94 \%$ & & $3.03 \%$ \\
\hline $\mathrm{Na}_{2} \mathrm{O}$ & $1.46 \%$ & $0.8 \%$ & $1.96 \%$ & $6.00 \%$ & $6.59 \%$ \\
\hline $\mathrm{NiO}$ & $1.99 \%$ & & $1.76 \%$ & & $0.54 \%$ \\
\hline $\mathrm{P}_{2} \mathrm{O}_{5}$ & $0.47 \%$ & & $0.42 \%$ & & $0.13 \%$ \\
\hline $\mathrm{PbO}$ & $0.56 \%$ & & $0.50 \%$ & & $0.15 \%$ \\
\hline $\mathrm{SO}_{3}$ & $0.93 \%$ & & $0.82 \%$ & & $0.25 \%$ \\
\hline $\mathrm{Sb}_{2} \mathrm{O}_{5}$ & $0.78 \%$ & & $0.69 \%$ & & $0.21 \%$ \\
\hline $\mathrm{SeO}_{2}$ & $0.55 \%$ & & $0.49 \%$ & & $0.15 \%$ \\
\hline $\mathrm{SiO}_{2}$ & $0.08 \%$ & & $0.07 \%$ & $45.51 \%$ & $45.53 \%$ \\
\hline $\mathrm{SrO}$ & $0.16 \%$ & $8.6 \%$ & $7.60 \%$ & & $2.32 \%$ \\
\hline$\overline{\mathrm{TeO}_{2}}$ & $0.53 \%$ & & $0.47 \%$ & & $0.14 \%$ \\
\hline $\mathrm{TiO}_{2}$ & $0.23 \%$ & & $0.21 \%$ & & $0.06 \%$ \\
\hline $\mathrm{ZnO}$ & & & & $2.00 \%$ & $2.00 \%$ \\
\hline $\mathrm{ZrO}_{2}$ & $13.19 \%$ & & $11.68 \%$ & & $3.56 \%$ \\
\hline TOTAL & $100 \%$ & $13.16 \%$ & $100 \%$ & $69.61 \%$ & $100 \%$ \\
\hline $\begin{array}{l}\text { Total Oxides } \\
(\mathrm{kg})\end{array}$ & 82,997 & 10,920 & 93,917 & 214,108 & 308,025 \\
\hline \multicolumn{6}{|c|}{ Volatiles, $\mathrm{g} / 100 \mathrm{~g}$ oxides } \\
\hline $\mathrm{CO}_{3}$ & & $4.96^{*}$ & 3.00 & & \\
\hline $\mathrm{NO}_{2}$ & & & 1.39 & & \\
\hline $\mathrm{NO}_{3}$ & & 1.63 & 1.67 & & \\
\hline TOC & & & 1.3 & & \\
\hline
\end{tabular}

- If all $\mathrm{Sr}$ in pretreatment is precipitated as $\mathrm{SrCO}_{3}$ 
Table 2.2. Composition of Melter Feed Simulant to Produce 10 Metric Tons of HLW98-31 Glass from AZ-101 Waste Plus Pretreatment Products.

\begin{tabular}{|c|c|c|c|}
\hline \multicolumn{2}{|c|}{ AZ-101+ Pretreatment Products } & \multicolumn{2}{|c|}{ Glass-Forming Additives } \\
\hline Starting Materials & Target Weight, $\mathrm{kg}$ & Starting Materials & Target Weight, $\mathrm{kg}$ \\
\hline $\mathrm{Al}(\mathrm{OH})_{3}$ & 1131.6 & & \\
\hline $\mathrm{Na}_{2} \mathrm{HAsO}_{4}$ & 7.5 & & \\
\hline $\mathrm{Ba}(\mathrm{OH})_{2} * 8 \mathrm{H}_{2} \mathrm{O}$ & 8.7 & & \\
\hline $\mathrm{CaCO}_{3}$ & 44.1 & & \\
\hline $\mathrm{CdO}$ & 37.2 & & \\
\hline $\mathrm{Ce}(\mathrm{OH})_{4}$ & 10.1 & & \\
\hline $\mathrm{Cr}_{2} \mathrm{O}_{3}^{*} 1.5 \mathrm{H}_{2} \mathrm{O}$ & 5.2 & & \\
\hline $\mathrm{CsOH}(50 \%$ Solution $)$ & 17.5 & & \\
\hline $\mathrm{CuSO}_{4} * 5 \mathrm{H}_{2} \mathrm{O}$ & 8.8 & & \\
\hline $\mathrm{NaF}$ & 8.4 & & \\
\hline $\mathrm{Fe}(\mathrm{OH})_{3}$ Slurry & 10553.5 & & \\
\hline $\mathrm{KNO}_{3}$ & 36.3 & & \\
\hline $\mathrm{La}(\mathrm{OH})_{3} * 3 \mathrm{H}_{2} \mathrm{O}$ & 48.5 & & \\
\hline $\mathrm{Li}_{2} \mathrm{CO}_{3}$ & & $\mathrm{Li}_{2} \mathrm{CO}_{3}$ & 1484.1 \\
\hline$\left(\mathrm{MgCO}_{3}\right) 4\left(\mathrm{Mg}(\mathrm{OH})_{2} * 5 \mathrm{H}_{2} \mathrm{O}\right)$ & 15.1 & & \\
\hline $\mathrm{MnO}_{2}$ & 371.5 & & \\
\hline \multirow[t]{2}{*}{$\mathrm{NaOH}(50 \%$ Solution $)$} & 12.8 & & \\
\hline & & $\mathrm{Na}_{2} \mathrm{~B}_{4} \mathrm{O}_{7} * 10 \mathrm{H}_{2} \mathrm{O}$ & 2738.7 \\
\hline \multicolumn{4}{|l|}{$\mathrm{Ni}\left(\mathrm{NO}_{3}\right)_{2}{ }^{*} 6 \mathrm{H}_{2} \mathrm{O}$} \\
\hline $\mathrm{Ni}(\mathrm{OH})_{2}$ & 66.7 & & \\
\hline $\mathrm{FePO}_{4}(80 \%)$ & 33.8 & & \\
\hline $\mathrm{PbCO}_{3} * \mathrm{~Pb}(\mathrm{OH})_{2}$ & 17.3 & & \\
\hline $\mathrm{Na}_{2} \mathrm{SO}_{4}$ & 39.4 & & \\
\hline $\mathrm{Sb}_{2} \mathrm{O}_{5}$ & 21.1 & & \\
\hline $\mathrm{SeO}_{2}$ & 14.9 & & \\
\hline $\mathrm{SiO}_{2}$ & 2.2 & $\mathrm{SiO}_{2}$ & 4551.8 \\
\hline $\mathrm{Sr}\left(\mathrm{NO}_{3}\right)_{2}$ & 57.3 & & \\
\hline $\mathrm{Sr}(\mathrm{OH})_{2} * 8 \mathrm{H}_{2} \mathrm{O}$ & 522.2 & & \\
\hline $\mathrm{TeO}_{2}$ & 14.2 & & \\
\hline $\mathrm{TiO}_{2}$ & 6.3 & & \\
\hline $\mathrm{ZnO}$ & & $\mathrm{ZnO}$ & 200.0 \\
\hline $\mathrm{ZrOOH}\left(\mathrm{CO}_{3}\right)_{0.5}(50 \%)$ & 570.9 & & \\
\hline $\mathrm{Zr}(\mathrm{OH})_{4}(50 \%)$ & 330.8 & & \\
\hline $\mathrm{KCl}$ & 1.5 & & \\
\hline $\mathrm{Na}_{2} \mathrm{CO}_{3}$ & & $\mathrm{Na}_{2} \mathrm{CO}_{3}$ & 264.3 \\
\hline $\mathrm{NaNO}_{2}$ & 63.6 & & \\
\hline \multicolumn{4}{|l|}{$\mathrm{NaNO}_{3}$} \\
\hline $\mathrm{C}_{2} \mathrm{H}_{2} \mathrm{O}_{4} * 2 \mathrm{H}_{2} \mathrm{O}$ & 208.1 & & \\
\hline $\mathrm{H}_{2} \mathrm{O}$ & 1897.6 & & \\
\hline \multirow[t]{2}{*}{ TOTAL } & $16,184.8$ & TOTAL & $9,431.9$ \\
\hline & & FEED TOTAL & $25,616.7$ \\
\hline
\end{tabular}


Table 2.3. Measured Properties of Feed Samples from DM1200 Commissioning Tests.

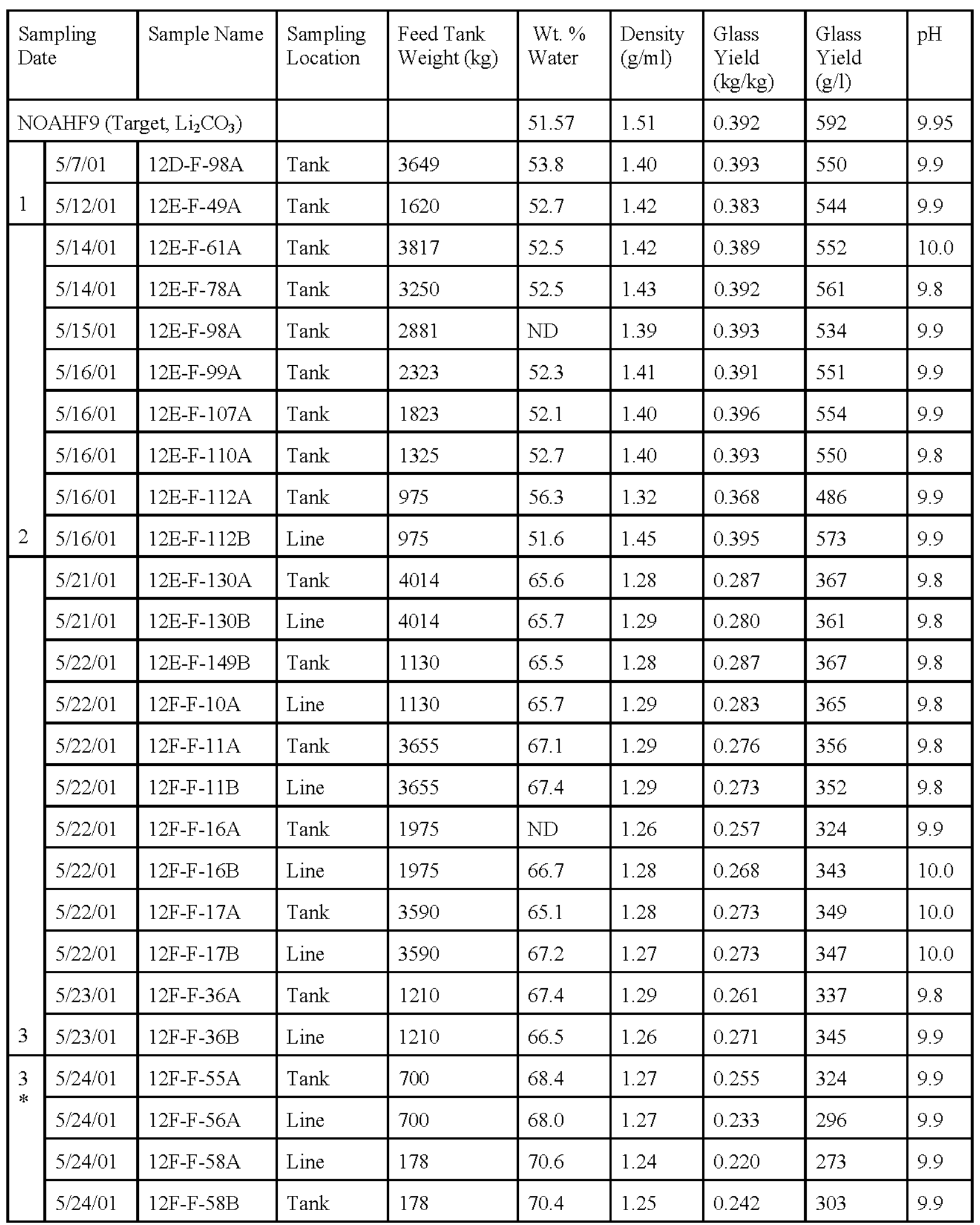

ND - No Data; * $=$ Samples taken at end of Test 3 when tank level fell below mixer blades. 
Table 2.4. Rheological Properties of Feed Samples from DM1200 Commissioning Tests.

\begin{tabular}{|c|c|c|c|c|c|c|c|c|}
\hline \multirow{2}{*}{\multicolumn{2}{|c|}{$\begin{array}{c}\text { Test \# } \\
\text { Sampling } \\
\text { Date }\end{array}$}} & \multirow{2}{*}{$\begin{array}{l}\text { Sample } \\
\text { Name }\end{array}$} & \multirow{2}{*}{$\begin{array}{c}\text { Sample } \\
\text { Location }\end{array}$} & \multirow{2}{*}{$\begin{array}{c}\text { Feed Tank } \\
\text { Weight } \\
(\mathrm{kg})\end{array}$} & \multirow{2}{*}{$\begin{array}{l}\text { Glass } \\
\text { Yield } \\
(\mathrm{g} / \mathrm{l})\end{array}$} & \multicolumn{3}{|c|}{ Viscosity $(\mathrm{P})$} \\
\hline & & & & & & @ 1/s & (a) 10/s & @ 100/s \\
\hline 1 & $5 / 12 / 01$ & $12 \mathrm{E}-\mathrm{F}-49 \mathrm{~A}$ & Tank & 1620 & 383 & 37.8 & 4.1 & 0.62 \\
\hline & $5 / 14 / 01$ & $12 \mathrm{E}-\mathrm{F}-61 \mathrm{~A}$ & Tank & 3817 & 389 & 36.3 & 4.6 & 0.72 \\
\hline 2 & $5 / 14 / 01$ & 12E-F-78A & Tank & 3250 & 392 & 28.5 & 4.8 & 0.76 \\
\hline & $5 / 16 / 01$ & 12E-F-112B & Line & 975 & 395 & 30.0 & 7.4 & 1.13 \\
\hline \multirow{2}{*}{3} & $5 / 21 / 01$ & $12 \mathrm{E}-\mathrm{F}-130 \mathrm{~A}$ & Tank & 4014 & 287 & 5.23 & 0.59 & 0.12 \\
\hline & $5 / 24 / 01$ & $12 \mathrm{~F}-\mathrm{F}-58 \mathrm{~B}$ & Tank & 178 & 242 & 3.12 & 0.37 & 0.09 \\
\hline
\end{tabular}


Table 2.5. Chemical Compositions of Feed Samples for DM1200 AZ-101 Tests (wt\%).

\begin{tabular}{|c|c|c|c|c|c|c|c|c|c|c|c|c|c|c|}
\hline \multirow{3}{*}{\begin{tabular}{|l} 
Test \# \\
Oxide \\
\end{tabular}} & \multirow{3}{*}{ Target } & \multicolumn{5}{|c|}{1} & \multicolumn{8}{|c|}{2} \\
\hline & & \multicolumn{3}{|c|}{$12 \mathrm{D}-\mathrm{F}-98 \mathrm{~A}$} & \multicolumn{2}{|c|}{$12 \mathrm{E}-\mathrm{F}-49 \mathrm{~A}$} & \multicolumn{2}{|c|}{$12 \mathrm{E}-\mathrm{F}-61 \mathrm{~A}$} & \multicolumn{2}{|c|}{$12 \mathrm{E}-\mathrm{F}-78 \mathrm{~A}$} & \multicolumn{2}{|c|}{ 12E-F-98A } & \multicolumn{2}{|c|}{ 12E-F-99A } \\
\hline & & XRF & DC & & XRF & DCP & XRF & DCP & XRF & DCP & XRF & DCP & XRF & DCP \\
\hline${ }_{2} \mathrm{O}_{3}$ & 7.40 & 7.85 & 7.55 & 7.55 & 7.54 & 6.98 & 7.52 & 7.08 & 7.47 & 7.25 & 8.02 & 7.53 & 7.64 & 7.5 \\
\hline $\mathrm{S}_{2} \mathrm{O}_{3}$ & 0.04 & 0.04 & 0.04 & 0.01 & 0.03 & 0.02 & 0.04 & 0.03 & 0.04 & 0.03 & 0.04 & 0.05 & 0.04 & 0.0 \\
\hline $\mathrm{O}_{3}$ & 10.00 & 10.42 & 10.42 & 10.54 & 10.51 & $\mid 10.51$ & 10.43 & 10.43 & 10.74 & 10.74 & 11.03 & 11.03 & 11.00 & 11.0 \\
\hline $\mathrm{aO}$ & 04 & $\mathrm{ND}$ & 0.06 & 0.06 & $\mathrm{ND}$ & 0.06 & $\mathrm{ND}$ & 0.06 & $\mathrm{ND}$ & 0.06 & $\mathrm{ND}$ & 0.06 & $\mathrm{ND}$ & $\overline{0.0}$ \\
\hline $\mathrm{O}$ & & 37 & 39 & 37 & 0.38 & 54 & 0.36 & 40 & 0.39 & 39 & 38 & 40 & 0.39 & .4 \\
\hline$\overline{\mathrm{O}}$ & 37 & 40 & 33 & 33 & 0.37 & 0.3. & 42 & 0.34 & 0.45 & 0.37 & 36 & 0.31 & .40 & 0.3 \\
\hline $\mathrm{eO}_{2}$ & 08 & .08 & $\mathrm{NA}$ & $\mathrm{NA}$ & 0.08 & $\mathrm{NA}$ & 0.09 & NA & 0.07 & $\mathrm{NA}$ & 0.06 & $\mathrm{NA}$ & 0.07 & $\pi$ \\
\hline & 01 & $\mathrm{ND}$ & $\mathrm{NA}$ & $\mathrm{NA}$ & 0.01 & NA & $\mathrm{ND}$ & NA & $\mathrm{ND}$ & $\mathrm{NA}$ & $\mathrm{ND}$ & $\mathrm{NA}$ & $\mathrm{ND}$ & $\mathrm{NA}$ \\
\hline $\mathrm{r}_{2} \mathrm{O}_{3}$ & 04 & 0.03 & 0.02 & 0.03 & 0.01 & 0.01 & $\mathrm{ND}$ & 0.01 & 0.01 & 0.01 & 0.01 & 0.01 & 0.01 & 0.01 \\
\hline $\mathrm{s}_{2} \mathrm{O}$ & 08 & 0.08 & $\mathrm{NA}$ & $\mathrm{NA}$ & 0.09 & $\mathrm{NA}$ & 0.09 & $\mathrm{NA}$ & 0.09 & $\mathrm{NA}$ & 0.08 & $\mathrm{NA}$ & 0.09 & $\mathrm{NA}$ \\
\hline $\mathrm{dO}$ & 03 & 0.04 & 0.03 & 0.03 & 0.03 & 0.03 & 0.03 & 0.03 & 0.04 & 0.03 & 0.03 & 0.03 & 0.03 & 0.0 \\
\hline & 04 & $\mathrm{NA}$ & $\mathrm{NA}$ & $\overline{\mathrm{NA}}$ & $\overline{\mathrm{NA}}$ & $\sqrt{ } A$ & $\mathrm{NA}$ & NA & $\mathrm{NA}$ & $\mathrm{NA}$ & $\mathrm{NA}$ & $\mathrm{NA}$ & $\mathrm{NA}$ & $\mathrm{N}$ \\
\hline${ }_{2} \mathrm{O}_{3}$ & 39 & 0.47 & 10.11 & 10.08 & 10.26 & 8.88 & 10.46 & 9.04 & 10.67 & 8.96 & 10.07 & 8.93 & 0.31 & 3.8 \\
\hline $\mathrm{O}$ & 7 & 30 & 0.25 & 0.23 & 0.25 & 0.21 & 0.23 & 0.20 & 0.25 & 0.20 & 0.25 & 0.21 & 0.23 & 0.1 \\
\hline${ }_{2} \mathrm{O}_{3}$ & 32 & 18 & $\mathrm{NA}$ & $\overline{\mathrm{NA}}$ & $\overline{0.19}$ & $\overrightarrow{\mathrm{NA}}$ & 0.18 & $\mathrm{NA}$ & 0.18 & $\mathrm{NA}$ & 0.18 & $\mathrm{NA}$ & 0.17 & $\overline{\mathrm{N}_{t}}$ \\
\hline $\mathrm{i}_{2} \mathrm{O}$ & & .04 & 5.04 & 5.01 & 4.84 & 4.84 & 4.98 & 4.98 & 5.36 & 5.36 & 5.01 & 5.01 & 5.14 & 5.1 \\
\hline $\mathrm{gO}$ & 16 & NA & 0.10 & 0.09 & NA & 0.10 & NA & 0.10 & NA & 0.09 & NA & 0.10 & NA & 11 \\
\hline $\mathrm{nO}$ & 03 & 20 & 2.86 & 2.89 & 3.23 & 2.84 & 3.22 & 2.78 & 3.29 & 2.78 & 3.08 & 2.80 & 3.13 & 2.8 \\
\hline $\mathrm{a}_{2} \mathrm{O}$ & & 77 & 31 & 6.36 & $\overline{7.41}$ & 6.24 & 7.43 & 6.7. & 6.62 & 6. & 7.38 & 6.47 & 7.73 & 0.0 \\
\hline $\mathrm{O}$ & 54 & 52 & 0.52 & 0.50 & 0.52 & 0 & 0.53 & 0.5 & 0.53 & 0.5 & 0.49 & 0.51 & .51 & $\ldots$ \\
\hline $\mathrm{O}_{5}$ & & 15 & 22 & 0.21 & 0.14 & 0. & 0.15 & 0.2 & 0.15 & 0.1 & 0.16 & 0.19 & .15 & 0.2 \\
\hline $\mathrm{O}$ & & 4 & 20 & 0.19 & 0.14 & 0.20 & 13 & 0.2 & 0.14 & .2 & 13 & 0.20 & 0.13 & 0.1 \\
\hline $\mathrm{sb}_{2} \mathrm{O}_{3}$ & 21 & 18 & 0.22 & 0.31 & $\overline{0.18}$ & 0.33 & 0.20 & 0.27 & 0.19 & 0.31 & 0.19 & 0.22 & 0.21 & 0.2 \\
\hline $\mathrm{SeO}_{2}$ & 15 & 0.03 & 0.03 & 0.02 & 0.04 & 0.03 & 0.05 & 0.03 & 0.06 & 0.03 & 0.04 & 0.04 & 0.03 & 0.0 \\
\hline $\mathrm{SiO}_{2}$ & 45.53 & 45.42 & 1.63 & 42.00 & 46.08 & 41.87 & 45.81 & 42.29 & 45.27 & 41.74 & 45.93 & \begin{tabular}{|l|}
41.96 \\
\end{tabular} & \begin{tabular}{|l|}
45.28 \\
\end{tabular} & 41.38 \\
\hline $\mathrm{SO}_{3}$ & 25 & 0.54 & $\mathrm{NA}$ & $\overline{\mathrm{NA}}$ & 0.18 & $\mathrm{NA}$ & 0.18 & $\mathrm{NA}$ & 0.24 & $\mathrm{NA}$ & 0.18 & $\mathrm{NA}$ & 0.16 & $\mathrm{~N}$ \\
\hline $\mathrm{SrO}$ & 32 & 16 & 2.06 & 2.22 & 2.12 & 1.98 & 2.14 & 1.96 & 2.22 & 2.00 & 2.00 & 2.04 & 2.08 & 2.0 \\
\hline $\mathrm{O}_{2}$ & & 10 & 0.13 & 0.13 & 0.11 & 0.15 & 0.12 & 0.13 & 0.13 & 0.13 & 0.11 & 0.12 & 0.11 & $\overline{0.1}$ \\
\hline $\mathrm{O}_{2}$ & $\overline{06}$ & 07 & 0.10 & 0.09 & 0.07 & 0.1 & 0.06 & 0.10 & 0.07 & 0.1 & 0.07 & 0.10 & 0.07 & 0.1 \\
\hline 10 & & & 1.92 & 1.94 & 1.94 & 1.97 & 1.95 & 1.95 & 2.01 & 1.9 & 1.85 & 1.95 & 1.90 & 1.9 \\
\hline $\mathrm{ZrO}_{2}$ & 3.56 & 4.13 & 3.92 & 3.92 & 4.10 & 3.80 & 4.07 & 3.67 & 4.21 & 3.71 & 3.80 & 3.79 & 4.01 & 3.8 \\
\hline $\mathrm{dm}$ & 00.00 & 00.90 & 94.47 & 95.06 & 0.82 & 92.54 & 00.87 & 93.12 & 00.92 & 93.56 & 00.92 & 94.03 & 01.02 & 3.6 \\
\hline
\end{tabular}

NA: Not analyzed; ND: Not detected. 
Table 2.5. Chemical Compositions of Feed Samples for DM1200 AZ-101 Tests (wt\%) (continued).

\begin{tabular}{|c|c|c|c|c|c|c|c|c|c|c|c|c|c|}
\hline Test \# & & & & 2 & & & & & & & 3 & & \\
\hline Oxide & $12 \mathrm{E}-\mathrm{F}-\mathrm{I}$ & $107 \mathrm{~A}$ & $12 \mathrm{E}-\mathrm{F}-1$ & $-110 \mathrm{~A}$ & $12 \mathrm{E}-\mathrm{F}-1$ & $-112 \mathrm{~A}$ & $12 \mathrm{E}-\mathrm{F}-$ & $112 \mathrm{~B}$ & $12 \mathrm{E}-\mathrm{F}-$ & $-130 \mathrm{~A}$ & 12E-F-130B & $12 \mathrm{E}-\mathrm{F}-$ & $149 \mathrm{~B}$ \\
\hline Method & $\mathrm{XRF}$ & DCP & XRF & DCP & XRF & DCP & $\mathrm{XRF}$ & DCP & $\mathrm{XRF}$ & DCP & $\mathrm{XRF}$ & $\mathrm{XRF}$ & DCP \\
\hline $\mathrm{Al}_{2} \mathrm{O}_{3}$ & 7.64 & 7.55 & 7.89 & 7.33 & 7.91 & 7.57 & 7.57 & 7.50 & 7.83 & 7.66 & 8.23 & 7.85 & 7.60 \\
\hline $\mathrm{As}_{2} \mathrm{O}_{3}$ & 0.04 & 0.01 & 0.04 & 0.01 & 0.04 & 0.05 & 0.04 & 0.04 & 0.04 & 0.03 & 0.04 & 0.04 & 0.04 \\
\hline $\mathrm{B}_{2} \mathrm{O}_{3}$ & 10.87 & 10.87 & 10.44 & 10.44 & 10.24 & 10.24 & 11.47 & \begin{tabular}{|l|}
11.47 \\
\end{tabular} & 10.50 & 10.50 & 9.57 & 10.57 & 10.57 \\
\hline $\mathrm{BaO}$ & $\mathrm{ND}$ & 0.05 & $\mathrm{ND}$ & 0.06 & $\mathrm{ND}$ & 0.06 & $\mathrm{ND}$ & 0.06 & $\mathrm{ND}$ & 0.06 & $\mathrm{ND}$ & $\mathrm{ND}$ & 0.06 \\
\hline $\mathrm{CaO}$ & 0.38 & 0.36 & 0.40 & 0.42 & 0.39 & 0.40 & 0.36 & 0.36 & 0.40 & 0.39 & 0.39 & 0.40 & 0.40 \\
\hline $\mathrm{CdO}$ & 0.37 & 0.30 & 0.38 & 0.29 & 0.31 & 0.31 & 0.29 & 0.29 & 0.41 & 0.32 & 0.42 & 0.37 & 0.33 \\
\hline $\mathrm{CeO}_{2}$ & 0.07 & $\mathrm{NA}$ & 0.07 & $\mathrm{NA}$ & 0.06 & NA & 0.07 & $\mathrm{NA}$ & 0.08 & $\mathrm{NA}$ & 0.07 & 0.07 & $\mathrm{NA}$ \\
\hline $\mathrm{Cl}$ & $\mathrm{ND}$ & $\mathrm{NA}$ & 0.01 & NA & 0.01 & NA & $\mathrm{ND}$ & NA & $\mathrm{ND}$ & NA & $\mathrm{ND}$ & 0.01 & $\mathrm{NA}$ \\
\hline $\mathrm{Cr}_{2} \mathrm{O}_{3}$ & 0.01 & 0.01 & $\mathrm{ND}$ & 0.01 & 0.01 & 0.01 & $\mathrm{ND}$ & 0.01 & 0.03 & 0.03 & 0.03 & 0.03 & 0.03 \\
\hline $\mathrm{Cs}_{2} \mathrm{O}$ & 0.08 & $\mathrm{NA}$ & 0.09 & NA & 0.07 & $\mathrm{NA}$ & 0.06 & $\mathrm{NA}$ & 0.11 & NA & 0.10 & 0.08 & $\mathrm{NA}$ \\
\hline $\mathrm{CuO}$ & 0.04 & 0.05 & 0.04 & 0.03 & 0.04 & 0.03 & 0.03 & 0.03 & 0.04 & 0.03 & 0.04 & 0.04 & 0.04 \\
\hline $\mathrm{F}$ & NA & $\mathrm{NA}$ & NA & NA & NA & NA & $\mathrm{NA}$ & NA & NA & $\mathrm{NA}$ & $\mathrm{NA}$ & NA & $\mathrm{NA}$ \\
\hline $\mathrm{Fe}_{2} \mathrm{O}_{3}$ & 10.75 & 8.76 & 10.74 & 9.30 & 10.97 & 9.70 & 10.15 & 9.09 & 10.43 & 8.68 & 10.36 & 10.27 & 9.14 \\
\hline $\mathrm{K}_{2} \mathrm{O}$ & 0.25 & 0.19 & 0.26 & 0.23 & 0.28 & 0.25 & 0.25 & 0.19 & 0.25 & 0.20 & 0.26 & 0.27 & 0.22 \\
\hline $\mathrm{La}_{2} \mathrm{O}_{3}$ & $\begin{array}{l}0.19 \\
\end{array}$ & $\mathrm{NA}$ & 0.18 & NA & 0.19 & NA & 0.18 & NA & 0.18 & $\mathrm{NA}$ & 0.24 & 0.19 & $\mathrm{NA}$ \\
\hline $\mathrm{Li}_{2} \mathrm{O}$ & 5.09 & 5.09 & $5.10^{*}$ & $5.10^{*}$ & $5.10^{\text {* }}$ & $5.10^{*}$ & 5.49 & 5.49 & 5.10 * & $5.10^{*}$ & $5.10^{*}$ & $5.10^{*}$ & $5.10^{*}$ \\
\hline $\mathrm{MgO}$ & NA & 0.09 & NA & 0.10 & NA & 0.09 & $\mathrm{NA}$ & 0.08 & NA & 0.10 & $\mathrm{NA}$ & $\mathrm{NA}$ & 0.10 \\
\hline $\mathrm{MnO}$ & 3.29 & 2.81 & 3.25 & 2.70 & 3.17 & 2.70 & 3.17 & 2.98 & 3.35 & 2.91 & 3.33 & 3.28 & 2.77 \\
\hline $\mathrm{Na}_{2} \mathrm{O}$ & 7.06 & 6.52 & 6.98 & 6.28 & 7.43 & 6.46 & 7.39 & 6.96 & 6.74 & 6.27 & 6.63 & 6.95 & 6.35 \\
\hline $\mathrm{NiO}$ & 0.54 & 0.49 & 0.54 & 0.54 & 0.54 & 0.54 & 0.50 & 0.50 & 0.55 & 0.51 & 0.55 & 0.55 & 0.52 \\
\hline $\mathrm{P}_{2} \mathrm{O}_{5}$ & 0.16 & 0.23 & 0.16 & 0.19 & 0.16 & 0.27 & 0.17 & 0.18 & 0.18 & 0.24 & 0.17 & 0.17 & 0.26 \\
\hline $\mathrm{PbO}$ & 0.14 & 0.19 & 0.14 & 0.20 & 0.14 & 0.18 & 0.13 & 0.19 & 0.15 & 0.20 & 0.14 & 0.14 & 0.18 \\
\hline $\mathrm{Sb}_{2} \mathrm{O}_{3}$ & 0.18 & 0.23 & 0.20 & 0.34 & 0.16 & 0.19 & 0.15 & 0.19 & 0.20 & 0.26 & 0.20 & 0.17 & 0.20 \\
\hline $\mathrm{SeO}_{2}$ & 0.04 & 0.06 & 0.03 & 0.04 & 0.04 & 0.05 & 0.03 & 0.00 & 0.04 & 0.03 & 0.02 & 0.04 & 0.04 \\
\hline $\mathrm{SiO}_{2}$ & 45.08 & 41.80 & 45.98 & 43.49 & 46.40 & 44.64 & 45.32 & 43.47 & 46.35 & 42.23 & 47.35 & 46.29 & 44.45 \\
\hline $\mathrm{SO}_{3}$ & 0.17 & $\mathrm{NA}$ & 0.20 & $\mathrm{NA}$ & 0.27 & $\mathrm{NA}$ & 0.16 & $\mathrm{NA}$ & 0.24 & $\mathrm{NA}$ & 0.18 & 0.24 & $\mathrm{NA}$ \\
\hline $\mathrm{SrO}$ & 2.20 & 2.05 & 2.19 & 1.96 & 2.19 & 2.06 & 2.06 & 2.09 & 2.28 & 2.12 & 2.23 & 2.22 & 2.09 \\
\hline $\mathrm{TeO}_{2}$ & 0.09 & 0.11 & 0.11 & 0.12 & 0.09 & 0.13 & 0.08 & 0.09 & 0.12 & 0.14 & 0.11 & 0.12 & 0.14 \\
\hline $\mathrm{TiO}_{2}$ & 0.07 & 0.10 & 0.07 & 0.11 & 0.07 & 0.10 & 0.07 & 0.09 & 0.07 & 0.10 & 0.09 & 0.07 & 0.10 \\
\hline $\mathrm{ZnO}$ & 2.01 & 1.94 & 2.01 & 1.95 & 2.01 & 2.01 & 1.88 & 1.85 & 2.03 & 2.03 & 2.01 & 2.00 & 1.96 \\
\hline $\mathrm{ZrO}_{2}$ & 4.10 & 3.79 & 4.18 & 3.60 & 4.11 & 3.80 & 3.85 & 3.82 & 4.33 & 4.01 & 4.23 & 4.17 & 3.80 \\
\hline Sum & 100.90 & 93.67 & 100.88 & 94.06 & 100.80 & $\mid 95.31$ & 100.89 & 97.03 & 100.83 & 93.00 & 100.72 & 100.90 & 95.69 \\
\hline
\end{tabular}

NA: Not analyzed; ND: not detected; * = Average of values obtained for same feed batch. 
Table 2.5. Chemical Compositions of Feed Samples for DM1200 AZ-101 Tests (wt\%) (continued).

\begin{tabular}{|c|c|c|c|c|c|c|c|c|c|c|c|c|c|}
\hline est \# & \\
\hline Dxide & \multicolumn{2}{|c|}{$12 \mathrm{~F}-\mathrm{F}-10 \mathrm{~A}$} & \multicolumn{2}{|c|}{$12 \mathrm{~F}-\mathrm{F}-11 \mathrm{~A}$} & \multicolumn{2}{|c|}{$12 \mathrm{~F}-\mathrm{F}-11 \mathrm{~B}$} & \multicolumn{2}{|c|}{$12 \mathrm{~F}-\mathrm{F}-16 \mathrm{~A}$} & \multicolumn{2}{|c|}{$12 \mathrm{~F}-\mathrm{F}-16 \mathrm{~B}$} & \multicolumn{2}{|c|}{$12 \mathrm{~F}-\mathrm{F}-17 \mathrm{~A}$} & F-F-17B \\
\hline Method & \begin{tabular}{|l|}
$\mathrm{XRF}$ \\
\end{tabular} & \begin{tabular}{|l|}
$\mathrm{DCP}$ \\
\end{tabular} & XRF & DCP & XRF & DCP & XRF & DCP & XRF & \begin{tabular}{|l|}
$\mathrm{DCP}$ \\
\end{tabular} & XRF & $\overline{\mathrm{DCP}}$ & $\mathrm{XRF}$ \\
\hline $\mathrm{Al}_{2} \mathrm{O}_{3}$ & 7.90 & 7.74 & 7.88 & 7.55 & 7.90 & 8.20 & 8.03 & 7.47 & 7.85 & 7.46 & 8.16 & 7.45 & 8.19 \\
\hline $\mathrm{As}_{2} \mathrm{O}_{3}$ & 0.04 & 0.03 & 0.04 & 0.05 & 0.05 & 0.05 & 0.04 & 0.03 & 0.04 & 0.10 & 0.04 & 0.06 & 0.05 \\
\hline $3_{2} \mathrm{O}_{3}$ & 0.77 & 10.77 & 10.04 & 10.04 & 10.55 & 10.55 & 9.84 & 9.84 & 10.03 & 10.03 & 9.74 & 9.74 & 9.86 \\
\hline $\mathrm{aO}$ & $\mathrm{ND}$ & 0.06 & $\mathrm{ND}$ & 0.06 & $\mathrm{ND}$ & 0.06 & $\mathrm{ND}$ & 0.06 & $\mathrm{ND}$ & 0.06 & $\mathrm{ND}$ & 0.06 & $\mathrm{ND}$ \\
\hline $\mathrm{aO}$ & 0.39 & 0.41 & 0.41 & 0.42 & 0.41 & 0.44 & 0.41 & 0.42 & 0.40 & 0.40 & 0.40 & 0.41 & 0.40 \\
\hline $\mathrm{dO}$ & 0.37 & 0.32 & 0.42 & 0.34 & 0.37 & 0.36 & 0.40 & 0.33 & 0.42 & 0.33 & 0.3 & 0.3 & .3 \\
\hline $\mathrm{eO}_{2}$ & 0.08 & $\mathrm{NA}$ & 0.07 & $\mathrm{NA}$ & 0.08 & NA & 0.09 & NA & 0.08 & NA & .07 & NA & .08 \\
\hline 1 & $\mathrm{ND}$ & $\mathrm{NA}$ & $\mathrm{ND}$ & NA & $\mathrm{ND}$ & NA & $\mathrm{ND}$ & $\mathrm{NA}$ & 0.01 & NA & $\mathrm{ND}$ & $\mathrm{NA}$ & ND \\
\hline $\mathrm{r}_{2} \mathrm{O}_{3}$ & 0.03 & 0.03 & 0.04 & 0.04 & 0.04 & 0.04 & 0.04 & 0.04 & 0.04 & 0.04 & 0.05 & 0.04 & 0.04 \\
\hline $\mathrm{Cs}_{2} \mathrm{O}$ & 0.08 & $\mathrm{NA}$ & 0.09 & $\mathrm{NA}$ & 0.07 & NA & 0.08 & $\mathrm{NA}$ & 0.10 & $\mathrm{NA}$ & 0.08 & $\mathrm{NA}$ & 0.08 \\
\hline $\mathrm{uO}$ & 0.04 & 0.03 & 0.04 & 0.04 & 0.04 & 0.03 & 0.04 & 0.04 & 0.08 & 0.04 & 0.04 & 0.03 & $\overline{0.04}$ \\
\hline & $\mathrm{NA}$ & $\mathrm{NA}$ & $\mathrm{NA}$ & $\mathrm{NA}$ & $\mathrm{NA}$ & NA & $\mathrm{NA}$ & $\mathrm{NA}$ & $\mathrm{NA}$ & $\mathrm{NA}$ & $\mathrm{NA}$ & $\mathrm{NA}$ & $\mathrm{NA}$ \\
\hline $\mathrm{Fe}_{2} \mathrm{O}_{3}$ & 10.28 & 9.14 & 10.72 & 9.19 & 10.60 & 10.16 & 10.45 & 9.35 & 9.89 & 9.53 & 9.85 & 9.01 & 9.89 \\
\hline $\mathrm{K}_{2} \mathrm{O}$ & 26 & 0.22 & 0.27 & 0.23 & 0.28 & 0.24 & 0.27 & 0.22 & 25 & 0.20 & .2 & 0.2 & 0.27 \\
\hline $\mathrm{La}_{2} \mathrm{O}_{3}$ & 0.18 & $\mathrm{NA}$ & 0.19 & $\mathrm{NA}$ & 0.18 & NA & 0.18 & $\mathrm{NA}$ & 0.18 & NA & 0.17 & NA & 0.18 \\
\hline $\mathrm{Li}_{2} \mathrm{O}$ & $5.10^{*}$ & $5.10^{*}$ & 5.10 * & $5.10^{*}$ & $5.10^{*}$ & 5.10 * & $5.10^{*}$ & $5.10^{*}$ & $5.10^{*}$ & $5.10^{\text {氺 }}$ & 5.10 바 & 5.10 * & $5.10^{*}$ \\
\hline $\mathrm{MgO}$ & $\mathrm{NA}$ & 0.10 & $\mathrm{NA}$ & 0.10 & $\mathrm{NA}$ & 0.11 & $\mathrm{NA}$ & 0.10 & $\mathrm{NA}$ & 0.10 & NA & 0.10 & $\mathrm{NA}$ \\
\hline $\mathrm{MnO}$ & 3.26 & 3.40 & 3.42 & 2.74 & 3.39 & 2.95 & 3.36 & 2.68 & 3.30 & 2.71 & 3.30 & 2.72 & 3.28 \\
\hline $\mathrm{Na}_{2} \mathrm{O}$ & 7.15 & 6.53 & 6.82 & 6.09 & 6.54 & 6.49 & 6.65 & 5.97 & 6.84 & 5.99 & 7.19 & 6.04 & 6.92 \\
\hline $\mathrm{NiO}$ & 0.54 & 0.53 & 0.58 & 0.55 & 0.58 & 0.58 & 0.56 & 0.55 & 0.53 & 0.55 & 0.54 & 0.54 & 0.54 \\
\hline${ }_{2} \mathrm{O}_{5}$ & 17 & 0.27 & 0.17 & 0.22 & 0.17 & 0.26 & 0.17 & 0.21 & 0.17 & 0.26 & 0.1 & 0.22 & 0.18 \\
\hline $\mathrm{bO}$ & 14 & 0.18 & 0.15 & 0.19 & 0.15 & 0.20 & 0.15 & 0.19 & 0.14 & 0.19 & 0.12 & 0.19 & 0.14 \\
\hline $\mathrm{b}_{2} \mathrm{O}_{3}$ & 0.18 & 0.21 & 0.20 & 0.20 & 0.17 & 0.22 & 0.20 & 0.21 & 0.20 & 0.18 & 0.18 & 0.19 & 0.18 \\
\hline $\mathrm{SeO}_{2}$ & 03 & 0.05 & 0.03 & 0.00 & 0.02 & 0.06 & 0.03 & 0.03 & 0.02 & 0.07 & 0.03 & 0.13 & 0.02 \\
\hline $\mathrm{SiO}_{2}$ & 45.87 & 43.58 & 46.02 & 44.65 & $\overline{46.16}$ & 51.14 & 46.82 & 44.14 & 45.61 & \begin{tabular}{|l|}
45.73 \\
\end{tabular} & 47.42 & 42.57 & 47.63 \\
\hline $\mathrm{SO}_{3}$ & 0.16 & NA & 0.24 & $\mathrm{NA}$ & 0.22 & NA & 0.22 & $\mathrm{NA}$ & 0.20 & NA & 0.23 & $\mathrm{NA}$ & 0.22 \\
\hline $\mathrm{SrO}$ & 2.24 & 2.15 & 2.40 & 2.09 & 2.35 & 2.28 & 2.35 & 2.07 & 2.23 & 2.08 & 2.20 & 2.05 & 2.19 \\
\hline $\mathrm{eO}_{2}$ & 0.09 & 0.10 & 0.13 & 0.10 & 0.11 & 0.13 & 0.11 & 0.10 & 0.12 & 0.08 & 0.12 & 0.14 & 0.12 \\
\hline $\mathrm{TiO}_{2}$ & 0.07 & 0.10 & 0.07 & 0.10 & 0.07 & 0.11 & 0.08 & 0.10 & 0.08 & 0.10 & 0.07 & 0.10 & 0.07 \\
\hline $\mathrm{nO}$ & 1.98 & 2.02 & 2.12 & 2.03 & 2.10 & 2.14 & 2.08 & 2.02 & 1.96 & 2.02 & 1.96 & 2.01 & 1.96 \\
\hline $\mathrm{rO}_{2}$ & 4.24 & 3.76 & 4.51 & 3.68 & 4.36 & 3.94 & 4.45 & 3.76 & 4.25 & 3.81 & 4.12 & 3.73 & 4.16 \\
\hline um & 0.86 & 96.05 & 100.87 & 94.52 & 00.80 & 44.61 & 100.79 & 93.65 & 99.14 & 96.21 & 100.78 & 91.96 & 100.76 \\
\hline
\end{tabular}

NA: Not analyzed; ND: not detected; * = Average of values obtained for same feed batch. 
Table 2.5. Chemical Compositions of Feed Samples for DM1200 AZ-101 Tests (wt\%) (continued).

\begin{tabular}{|c|c|c|c|c|c|c|c|c|c|c|c|c|}
\hline \multirow{3}{*}{\begin{tabular}{|l|} 
Test \# \\
Oxide \\
Method \\
\end{tabular}} & \multicolumn{9}{|c|}{3} & & & \\
\hline & \multicolumn{2}{|c|}{$12 \mathrm{~F}-\mathrm{F}-36 \mathrm{~A}$} & \multicolumn{2}{|c|}{$12 \mathrm{~F}-\mathrm{F}-36 \mathrm{~B}$} & \multicolumn{2}{|c|}{$12 \mathrm{~F}-\mathrm{F}-55 \mathrm{~A}$} & \multirow{2}{*}{$\frac{12 \mathrm{~F}-\mathrm{F}-56 \mathrm{~A}}{\mathrm{XRF}}$} & \multicolumn{2}{|c|}{$12 \mathrm{~F}-\mathrm{F}-58 \mathrm{~A}$} & \multicolumn{2}{|c|}{$12 \mathrm{~F}-\mathrm{F}-58 \mathrm{~B}$} & \multirow[t]{2}{*}{ Target } \\
\hline & XRF & $\overline{\mathrm{DCP}}$ & XRF & DCP & XRF & $\overline{\mathrm{DCP}}$ & & XRF & $\overline{D C P}$ & $\overline{\mathrm{XRF}}$ & $\overline{D C P}$ & \\
\hline $\mathrm{Al}_{2} \mathrm{O}_{3}$ & 7.55 & 7.44 & 7.88 & 7.54 & 8.14 & 8.00 & 8.13 & 8.94 & 8.56 & 8.80 & 8.70 & 7.4 \\
\hline $\mathrm{As}_{2} \mathrm{O}_{3}$ & 0.04 & 0.06 & 0.04 & 0.04 & 0.04 & 0.03 & 0.04 & 0.05 & 0.03 & 0.05 & 0.05 & 0.0 \\
\hline $\mathrm{B}_{2} \mathrm{O}_{3}$ & 0.33 & 10.33 & 10.26 & 10.26 & 10.27 & 10.27 & 9.97 & 10.79 & 10.79 & 11.72 & 11.72 & 10.00 \\
\hline $\mathrm{BaO}$ & $\mathrm{ND}$ & 0.06 & $\mathrm{ND}$ & 0.06 & $\mathrm{ND}$ & 0.06 & $\mathrm{ND}$ & $\mathrm{ND}$ & 0.06 & $\mathrm{ND}$ & 0.06 & 0.0 \\
\hline $\mathrm{CaO}$ & 0.41 & 0.51 & 0.41 & 0.40 & 0.41 & 0.42 & 0.41 & 0.46 & 0.44 & 0.43 & 0.45 & .2 \\
\hline $\mathrm{CdO}$ & 38 & 33 & 0.39 & 0.34 & 0.33 & 0.3 & 0.38 & 0.42 & 0.3 & 0.40 & 0.3 & .3 \\
\hline $\mathrm{CeO}_{2}$ & .09 & $\mathrm{~A}$ & .08 & $\mathrm{NA}$ & 08 & $\mathrm{NA}$ & 0.08 & .07 & $\overline{\mathrm{NA}}$ & 0.06 & $\mathrm{NA}$ & 1.0 \\
\hline $\mathrm{Cl}$ & $\mathrm{ND}$ & $\mathrm{NA}$ & $\overline{\mathrm{ND}}$ & $\overline{\mathrm{NA}}$ & $\overline{\mathrm{ND}}$ & $\mathrm{NA}$ & $\mathrm{ND}$ & $\mathrm{ND}$ & NA & 0.01 & $\mathrm{NA}$ & .0 \\
\hline $\mathrm{Cr}_{2} \mathrm{O}_{3}$ & 0.04 & 0.04 & 0.04 & 0.04 & 0.05 & 0.04 & 0.04 & 0.05 & 0.05 & 0.05 & 0.05 & .0 \\
\hline $\mathrm{Cs}_{2} \mathrm{O}$ & 0.07 & $\mathrm{NA}$ & 0.08 & $\mathrm{NA}$ & 0.07 & $\mathrm{NA}$ & 0.09 & 0.10 & $\mathrm{NA}$ & 0.10 & NA & 10 \\
\hline $\mathrm{CuO}$ & 0.04 & 0.04 & 0.04 & 0.04 & 0.04 & 0.05 & 0.04 & 0.06 & 0.04 & 0.04 & 0.04 & .0 \\
\hline F & $\mathrm{NA}$ & $\mathrm{NA}$ & $\mathrm{NA}$ & $\overline{\mathrm{NA}}$ & $\mathrm{NA}$ & $\mathrm{NA}$ & $\mathrm{NA}$ & $\mathrm{NA}$ & NA & $\mathrm{NA}$ & $\mathrm{NA}$ & 0.0 \\
\hline $\mathrm{Fe}_{2} \mathrm{O}_{3}$ & 0.18 & 9.03 & 10.09 & 9.49 & 10.60 & 9.14 & 10.32 & 11.91 & 10.17 & 11.59 & 10.27 & 10.3 \\
\hline$\widehat{\mathrm{K}_{2} \mathrm{O}}$ & 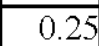 & 20 & 25 & 23 & 0.28 & 0.22 & 0.26 & 0.28 & 0.23 & 0.28 & 0.32 & 0.1 \\
\hline $\mathrm{a}_{2} \mathrm{O}_{3}$ & 10 & $\mathrm{NA}$ & 18 & $\mathrm{NA}$ & 0.19 & $\mathrm{~N}$ & 0.19 & 0.20 & $\mathrm{~N}_{1}$ & 0.19 & NA & 0.3 \\
\hline $\mathrm{i}_{2} \mathrm{O}$ & 10 * & 10 * & $5.10^{*}$ & $5.10^{*}$ & $5.10^{*}$ & $5.10^{\text {牲 }}$ & $5.10^{*}$ & $5.10^{*}$ & $5.10^{*}$ & $5.10 *$ & $5.10^{\text {氺 }}$ & 6.0 \\
\hline $\mathrm{MgO}$ & $\mathrm{NA}$ & 10 & $\mathrm{NA}$ & 0.10 & $\mathrm{NA}$ & 0.10 & $\mathrm{NA}$ & $\mathrm{NA}$ & 0.11 & $\mathrm{NA}$ & 0.11 & 0.0 \\
\hline $\mathrm{MnO}$ & 55 & 83 & 3.47 & 2.83 & $\overline{2.94}$ & 2.41 & 2.92 & 1.99 & 1.65 & 1.92 & 1.65 & 3.0 \\
\hline $\mathrm{Na}_{2} \mathrm{O}$ & 6.77 & 6.42 & 7.07 & 6.22 & 7.44 & 6.65 & 7.45 & 7.62 & 7.08 & 7.96 & 7.18 & 6. \\
\hline $\mathrm{NiO}$ & 0.56 & 0.51 & 0.56 & 0.52 & 0.59 & 0.56 & 0.57 & 0.67 & 0.60 & 0.64 & 0.60 & 0.3 \\
\hline$\overline{\mathrm{P}_{2} \mathrm{O}_{5}}$ & & 0.21 & 0.17 & 0.20 & 0.17 & $\overline{0.2}$ & $\overline{0.1}$ & 0.19 & 0 . & 0.19 & 0.25 & 0.1 \\
\hline $\mathrm{PbO}$ & 4 & 18 & 0.14 & 0.19 & 0.15 & 0.1 & 0.14 & 0.15 & 0. & 0.14 & 0.19 & 0.1 \\
\hline $\mathrm{Sb}_{2} \mathrm{O}_{3}$ & 17 & 18 & 18 & 0.17 & 0.15 & 0.1 & 0.18 & 0.17 & 0.1 & 0.17 & 0.16 & 0.2 \\
\hline $\mathrm{SeO}_{2}$ & 04 & 0.04 & .03 & 0.04 & 0.03 & 0.06 & 0.03 & 0.03 & 0.06 & 0.04 & 0.08 & 0.1 \\
\hline $\mathrm{SiO}_{2}$ & 46.19 & 43.24 & 46.25 & 44.12 & 45.63 & 42.94 & 45.97 & 42.73 & 40.20 & 42.35 & 40.37 & 45.5 \\
\hline $\mathrm{SO}_{3}$ & 0.19 & $\mathrm{NA}$ & 0.19 & $\mathrm{NA}$ & 0.19 & $\mathrm{NA}$ & 0.19 & 0.19 & $\mathrm{NA}$ & 0.24 & $\mathrm{NA}$ & 0.2 \\
\hline $\mathrm{SrO}$ & 2.31 & 2.10 & 2.29 & 2.11 & 2.33 & 2.20 & 2.34 & 2.55 & 2.27 & 2.44 & 2.31 & 2.3 \\
\hline $\mathrm{TeO}_{2}$ & 0.09 & 0.11 & 0.10 & 0.10 & 0.08 & 0.09 & 0.10 & 0.11 & 0.09 & 0.13 & 0.10 & $\overline{0.1}$ \\
\hline $\mathrm{TiO}_{2}$ & 0.07 & 0.09 & 0.07 & 0.10 & $\overline{0.07}$ & 0.10 & 0.07 & 0.08 & 0.11 & 0.08 & 0.11 & 0.0 \\
\hline $\mathrm{ZnO}$ & 2.08 & 1.97 & 2.02 & 1.97 & 2.11 & 2.05 & 2.05 & 2.30 & 2.17 & 2.20 & 2.19 & 2.0 \\
\hline $\mathrm{ZrO}_{2}$ & 4.26 & 3.71 & 4.24 & 3.81 & 4.32 & 3.97 & 4.43 & 4.85 & 4.12 & 4.64 & 4.20 & 3.5 \\
\hline um & 0.79 & 94.37 & 100.76 & 95.16 & 00.82 & 94.43 & 00.80 & 100.96 & 93.81 & 101.05 & 95.68 & 100.0 \\
\hline
\end{tabular}

NA: Not analyzed; ND: not detected; * = Average of values obtained for same feed batch. 
Table 3.1. Summary of Melter System Measured Parameters.

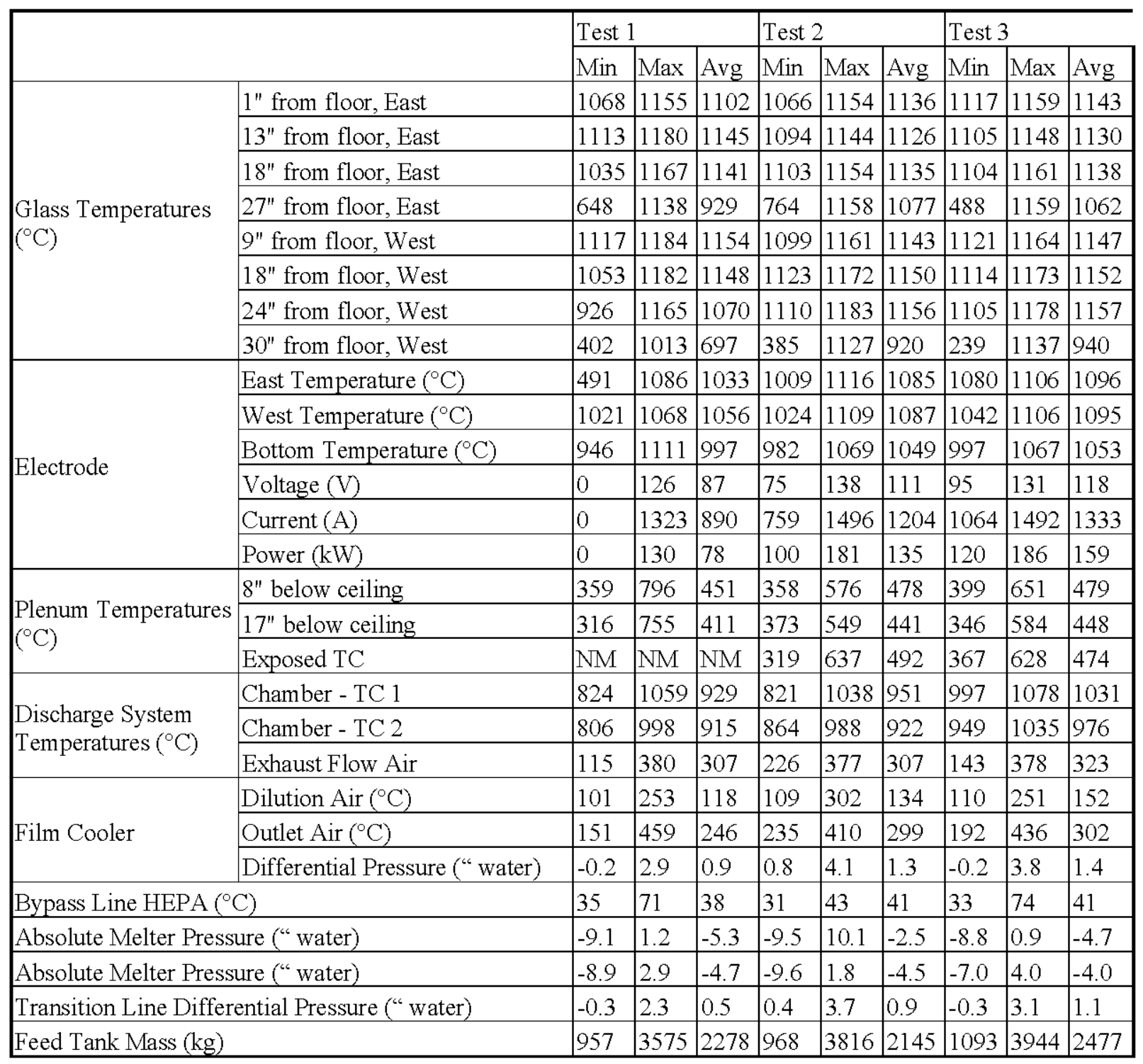


The Catholic University of America

Vitreous State Laboratory
ORP-51437, RevrgMelter 1200 Start-Up Tests with AZ-101

Final Report, VSL-01R0100-2, Rev.0

Table 4.1. Summary of Electronically Recorded Off-Gas System Parameters.

\begin{tabular}{|c|c|c|c|c|c|c|c|c|c|c|}
\hline & \multirow{2}{*}{ Parameter } & \multicolumn{3}{|c|}{ Test 1} & \multicolumn{3}{|c|}{ Test 2} & \multicolumn{3}{|c|}{ Test 3} \\
\hline & & Min & Max & Avg & Min & Max & Avg & Min & Max & Avg \\
\hline \multirow{14}{*}{ 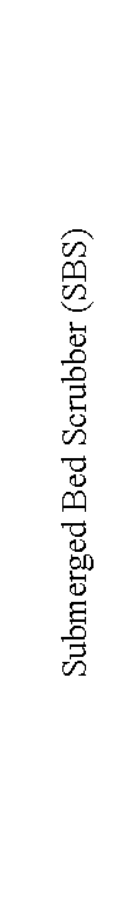 } & Differential Pressure (in W.C.) & 1.1 & 55.6 & 50.1 & 43.8 & 57.6 & 50.2 & 2.7 & 57.5 & 50.5 \\
\hline & Inlet gas Pressure (in W.C.) & -12.1 & 1.3 & -6.4 & -12.9 & -0.9 & -6.8 & -10.5 & 1.2 & -6.4 \\
\hline & Outlet gas Pressure (in W.C.) & -67.8 & -0.2 & -56.9 & -65.5 & -51.0 & -57.6 & -63.3 & -3.8 & -58.1 \\
\hline & Inlet gas Temp. $\left({ }^{\circ} \mathrm{C}\right)$ & 143.1 & 533.3 & 223.6 & 209.2 & 324.5 & 62.0 & 171.9 & 518.1 & 291.7 \\
\hline & Outlet gas Temp. $\left({ }^{\circ} \mathrm{C}\right)$ & 16.9 & 53.4 & 21.6 & 24.7 & 33.6 & 28.3 & 22.9 & 55.0 & 34.7 \\
\hline & Chilled Water Inlet Temp $\left({ }^{\circ} \mathrm{C}\right)$ & 8.1 & 21.5 & 12.6 & 9.9 & 33.2 & 13.8 & 10.6 & 18.8 & 14.9 \\
\hline & Chilled Water Outlet Temp $\left({ }^{\circ} \mathrm{C}\right)$ & 9.8 & 25.6 & 13.7 & 11.8 & 33.1 & 15.9 & 13.5 & 24.4 & 17.9 \\
\hline & $48^{\prime \prime}$ Depth Temp. $\left({ }^{\circ} \mathrm{C}\right)$ & 15.6 & 55.2 & 20.8 & 24.1 & 34.7 & 27.9 & 23.2 & 57.0 & 34.8 \\
\hline & $60^{\prime \prime}$ Depth Temp. $\left({ }^{\circ} \mathrm{C}\right)$ & 15.6 & 54.6 & 20.7 & 24.1 & 34.7 & 27.8 & 22.5 & 57.0 & 34.7 \\
\hline & $72^{\prime \prime}$ Depth Temp. $\left({ }^{\circ} \mathrm{C}\right)$ & 16.3 & 54.6 & 21.5 & 24.4 & 35.3 & 28.6 & 23.2 & 57.0 & 35.3 \\
\hline & $78^{\prime \prime}$ Depth Temp. $\left({ }^{\circ} \mathrm{C}\right)$ & 15.6 & 54.6 & 20.9 & 24.1 & 34.7 & 27.9 & 22.5 & 57.0 & 34.9 \\
\hline & Heat Exch. Outlet Temp. $\left({ }^{\circ} \mathrm{C}\right)$ & 13.5 & 38.2 & 16.9 & 17.2 & 33.1 & 22.2 & 17.1 & 38.8 & 25.7 \\
\hline & Chilled Water Flow (gal $/ \mathrm{min}$ ) & 14.5 & 42.2 & 40.7 & 26.6 & 42.4 & 40.6 & 28.2 & 42.1 & 40.5 \\
\hline & Heat Exchanger Flow (gal/min) & 38.3 & 54.3 & 46.9 & 38.3 & 54.3 & 45.2 & 10.2 & 54.2 & 44.9 \\
\hline \multirow{3}{*}{ WESP } & Differential Pressure (in W.C.) & -0.0 & 2.9 & 1.6 & 0.9 & 3.2 & 1.8 & -0.0 & 3.8 & 1.6 \\
\hline & Inlet gas Temp. $\left({ }^{\circ} \mathrm{C}\right)$ & 21.7 & 53.4 & 25.6 & 27.5 & 32.9 & 30.0 & 26.2 & 55.3 & 35.0 \\
\hline & Outlet gas Temp. $\left({ }^{\circ} \mathrm{C}\right)$ & 29.7 & 53.4 & 32.7 & 31.0 & 38.3 & 36.1 & 33.4 & 54.1 & 39.8 \\
\hline \multirow{2}{*}{ HEPA\#1 } & Differential Pressure (in W.C.) & -0.1 & 0.3 & 0.2 & 0.2 & 0.3 & 0.2 & 0.0 & 0.3 & 0.2 \\
\hline & Outlet gas Temp. $\left({ }^{\circ} \mathrm{C}\right)$ & 115.6 & 124.5 & 122.6 & 31.7 & 123.8 & 116.3 & 108.3 & 124.0 & 122.6 \\
\hline PBS & Inlet gas Temp. $\left({ }^{\circ} \mathrm{C}\right)$ & 69.6 & 84.2 & 78.5 & 31.0 & 85.1 & 77.5 & 63.6 & 87.9 & 79.9 \\
\hline $\mathrm{TCO}$ & Outlet gas Temp. $\left({ }^{\circ} \mathrm{C}\right)$ & 68.2 & 77.5 & 73.4 & 32.0 & 78.7 & 73.1 & 23.4 & 79.4 & 72.7 \\
\hline
\end{tabular}


The Catholic University of America Vitreous State Laboratory

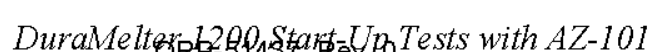

Final Report, VSL-01R0100-2, Rev.0

Table 4.2. WESP Current-Voltage Relationships Under Various Conditions.

\begin{tabular}{|c|c|c|c|c|c|c|c|}
\hline \multirow[t]{2}{*}{$\mathrm{V},[\mathrm{kV}]$} & $\begin{array}{l}\mathrm{F}_{\mathrm{t}}=0 \mathrm{scfm} \\
\mathrm{W}_{\mathrm{v}}=1.56 \% \mathrm{v} / \mathrm{v} \\
\mathrm{t}=28.5^{\circ} \mathrm{C} \\
\mathrm{P}_{\mathrm{a}}=29.46 \mathrm{AHg}\end{array}$ & $\begin{array}{l}\mathrm{F}_{\mathrm{t}}=0 \mathrm{scfm} \\
\mathrm{W}_{\mathrm{v}}=1.46 \% \mathrm{v} / \mathrm{v} \\
\mathrm{t}=27.5^{\circ} \mathrm{C} \\
\mathrm{P}_{\mathrm{a}}=29.62 \mathrm{AHg}\end{array}$ & $\begin{array}{l}\mathrm{F}_{\mathrm{t}}=182.9 \mathrm{scfm} \\
\mathrm{W}_{\mathrm{v}}=3.142 \% \mathrm{v} / \mathrm{v} \\
\mathrm{t}=23.0^{\circ} \mathrm{C} \\
\mathrm{P}_{\mathrm{a}}=26.41 \mathrm{Ahg}\end{array}$ & $\begin{array}{l}\mathrm{F}_{\mathrm{t}}=176.2 \mathrm{scfm} \\
\mathrm{W}_{\mathrm{v}}=3.396 \% \mathrm{v} / \mathrm{v} \\
\mathrm{t}=23.9^{\circ} \mathrm{C} \\
\mathrm{P}_{\mathrm{a}}=27.49 \mathrm{AHg}\end{array}$ & $\begin{array}{l}\mathrm{F}_{\mathrm{t}}=174.4 \mathrm{scfm} \\
\mathrm{W}_{\mathrm{v}}=4.025 \% \mathrm{v} / \mathrm{v} \\
\mathrm{t}=26.5^{\circ} \mathrm{C} \\
\mathrm{P}_{\mathrm{a}}=25.40 \mathrm{AHg}\end{array}$ & $\begin{array}{l}\mathrm{F}_{\mathrm{t}}=173.7 \mathrm{scfm} \\
\mathrm{W}_{\mathrm{v}}=6.535 \% \mathrm{~V} / \mathrm{v} \\
\mathrm{t}=35.2^{\circ} \mathrm{C} \\
\mathrm{P}_{\mathrm{a}}=25.70 \mathrm{AHg}\end{array}$ & $\begin{array}{l}\mathrm{F}_{\mathrm{t}}=177.2 \mathrm{scfm} \\
\mathrm{W}_{\mathrm{v}}=23.05 \% \mathrm{v} / \mathrm{v} \\
\mathrm{t}=60.9^{\circ} \mathrm{C} \\
\mathrm{P}_{\mathrm{a}}=26.61 \mathrm{AHg}\end{array}$ \\
\hline & $\mathrm{I}^{(1)},[\mathrm{mA}]$ & $\mathrm{I}^{(1)},[\mathrm{mA}]$ & $\mathrm{I}^{(2)},[\mathrm{mA}]$ & $\mathrm{I}^{(2)},[\mathrm{mA}]$ & $\mathrm{I}^{(3)},[\mathrm{mA}]$ & $\mathrm{I}^{(3)},[\mathrm{mA}]$ & $\mathrm{I}^{(3)},[\mathrm{mA}]$ \\
\hline 0.00 & 0.01 & 0.00 & 0.00 & 0.00 & 0.00 & 0.00 & 0.00 \\
\hline 2.50 & 0.01 & 0.00 & 0.00 & 0.00 & 0.00 & 0.01 & 0.02 \\
\hline 5.00 & 0.04 & 0.00 & 0.00 & 0.00 & 0.00 & 0.03 & 0.06 \\
\hline 7.50 & 0.05 & 0.01 & 0.00 & 0.00 & 0.00 & 0.04 & 0.08 \\
\hline 10.00 & 0.08 & 0.02 & 0.02 & 0.03 & 0.02 & 0.11 & 0.18 \\
\hline 12.00 & 0.30 & 0.20 & 0.24 & 0.17 & 0.26 & 0.55 & 0.61 \\
\hline 14.00 & 0.98 & 0.90 & 0.95 & 1.00 & 1.10 & 1.58 & 1.47 \\
\hline 16.00 & 2.13 & 2.15 & 2.69 & 2.82 & 2.95 & 3.09 & 2.62 \\
\hline 18.00 & 3.78 & 3.95 & 5.00 & 5.26 & 5.33 & 5.05 & 4.05 \\
\hline 20.00 & 5.92 & 6.16 & 7.82 & 8.20 & 8.22 & 7.73 & 5.96 \\
\hline 21.00 & 7.13 & 7.40 & 9.40 & 9.82 & 9.83 & 9.05 & 7.10 \\
\hline 22.00 & 8.41 & 8.78 & 11.09 & 11.55 & 11.64 & 10.57 & 8.34 \\
\hline 23.00 & 9.78 & 10.18 & 12.90 & 13.43 & 13.45 & 12.31 & 9.70 \\
\hline 24.00 & 11.22 & 11.70 & 14.81 & 15.46 & 15.45 & 14.19 & 11.13 \\
\hline 25.00 & 12.76 & 13.32 & 16.88 & 17.55 & 17.56 & 16.20 & 12.75 \\
\hline 26.00 & 14.39 & 15.03 & 19.04 & 19.02 & 19.76 & 18.25 & 14.35 \\
\hline 27.00 & 16.12 & 16.85 & & & & & 16.13 \\
\hline 28.00 & 17.97 & 17.75 & & & & & 17.88 \\
\hline 29.00 & 19.95 & & & & & & \\
\hline 30.00 & & & & & & & \\
\hline $\begin{array}{c}\text { Cut-off } \\
(a) 20.00 \mathrm{~mA},[\mathrm{kV}]\end{array}$ & 29.02 & 28.61 & 26.44 & 26.04 & 26.13 & 6.81 & 28.55 \\
\hline
\end{tabular}

(1) - No flow; Stagnant air at $\sim 40 \% \mathrm{R}_{\mathrm{H}}$.

(2) - Melter plenum air passed through SBS; No feed.

$\mathrm{F}_{\mathrm{t}}-$ Total flow through WESP.

(3) - Water fed to the melter at $2.0 \mathrm{lpm}$.

$W_{\mathrm{v}}-$ Moisture content.

$\mathrm{P}_{\mathrm{a}}$ - Gas pressure (absolute) at flow conditions.

$t \quad$ - Gas temperature at flow conditions. 
The Catholic University of America Vitreous State Laboratory
ORP-51437, ReyrgMelter 1200 Start-Up Tests with AZ-101

Final Report, VSL-01R0100-2, Rev.0

Table 4.3. Characteristics of SBS Samples from DM1200 Commissioning Tests.

\begin{tabular}{|c|c|c|c|c|c|c|c|}
\hline Test \# & $\begin{array}{c}\text { Sample Name } \\
- \text {-S- = SBS }\end{array}$ & $\mathrm{TSS}(\mathrm{mg} / \mathrm{l})$ & $\mathrm{TDS}(\mathrm{mg} / \mathrm{l})$ & Filtrate $\mathrm{pH}$ & Glass (kg) & $\begin{array}{l}\text { Blowdown } \\
\text { Volume } \\
\text { (gal) }\end{array}$ & $\begin{array}{c}\text { Cumulative } \\
\text { Blowdown } \\
\text { Volume } \\
\text { (gal) }\end{array}$ \\
\hline \multirow{3}{*}{ TO } & 12D-S-109A & 320 & $\mathrm{NA}$ & 2.75 & 5092 & 12 & 12 \\
\hline & 12D-S-113A & 494 & 2158 & 2.73 & 5092 & 42.6 & 54.6 \\
\hline & 12D-S-114A & 420 & 2156 & 2.75 & 5092 & 24.3 & 78.9 \\
\hline \multirow{22}{*}{1} & 12D-S-115A & 500 & 1980 & 2.93 & 5150 & 3.4 & 82.3 \\
\hline & 12D-S-115B & 456 & 2220 & 2.90 & 5175 & 44.9 & 127.2 \\
\hline & 12D-S-116A & 480 & 2090 & 2.90 & 5200 & 28.8 & 156 \\
\hline & 12D-S-121A & 382 & 2020 & 2.93 & 5450 & 39 & 195 \\
\hline & 12D-S-121B & 423 & 1738 & 3.04 & 5500 & 37.7 & 232.7 \\
\hline & 12D-S-128A & 413 & 1705 & 3.09 & 5670 & 31.6 & 264.3 \\
\hline & 12D-S-129A & 363 & 1208 & 3.08 & 5720 & 14.3 & 278.6 \\
\hline & 12D-S-129B & 360 & 1573 & 3.04 & 5770 & 34.4 & 313 \\
\hline & 12D-S-132A & 317 & 1603 & 2.95 & 5870 & 35 & 348 \\
\hline & 12D-S-137A & 312 & 1250 & 2.90 & 6050 & 31.1 & 379.1 \\
\hline & 12D-S-140A & 290 & 1212 & 2.87 & 6153 & 41.4 & 420.5 \\
\hline & 12D-S-142A & 265 & 1214 & 2.84 & 6153 & 15.7 & 436.2 \\
\hline & 12D-S-151A & 290 & 1206 & 2.88 & 6250 & 29.7 & 465.9 \\
\hline & 12E-S-17A & 234 & 1476 & 2.87 & 6300 & 25.7 & 491.6 \\
\hline & 12E-S-24A & 214 & 1290 & 2.81 & 6400 & 32 & 523.6 \\
\hline & 12E-S-38A & 192 & 1112 & 2.91 & 6550 & 43.6 & 567.2 \\
\hline & 12E-S-49A & 270 & 1216 & 2.93 & 6679 & 55 & 622.2 \\
\hline & 12E-S-69A & 301 & 1148 & 3.00 & 6679 & 33.1 & 655.3 \\
\hline & $12 \mathrm{E}-\mathrm{S}-76 \mathrm{~A}$ & 223 & 1074 & 2.97 & 6720 & 46.6 & 701.9 \\
\hline & 12E-S-77A & 233 & 838 & 2.85 & 6800 & 31 & 732.9 \\
\hline & $12 \mathrm{E}-\mathrm{S}-78 \mathrm{~A}$ & 312 & 1296 & 2.95 & 7000 & 21 & 753.9 \\
\hline & 12E-S-80A & 323 & 1326 & 2.92 & 7050 & 28.5 & 782.4 \\
\hline \multirow{7}{*}{2} & $12 \mathrm{E}-\mathrm{S}-81 \mathrm{~A}$ & 340 & 1406 & 2.88 & 7211 & 35 & 817.4 \\
\hline & 12E-S-86A & 405 & 1542 & 2.94 & 7250 & 36.7 & 854.1 \\
\hline & 12E-S-88A & 450 & 1614 & 2.98 & 7300 & 40.6 & 894.7 \\
\hline & 12E-S-90A & 453 & 1656 & 2.88 & 7500 & 65.4 & 960.1 \\
\hline & 12E-S-95A & 458 & 1766 & 2.87 & 7733 & 48.3 & 1008.4 \\
\hline & 12E-S-97A & 499 & 1905 & 2.89 & 7800 & 26 & 1034.4 \\
\hline & 12E-S-98A & 488 & 1888 & 2.87 & 7850 & 31.7 & 1066.1 \\
\hline
\end{tabular}


The Catholic University of America Vitreous State Laboratory
ORP-51437, RevrgMelter 1200 Start-Up Tests with AZ-101

Final Report, VSL-01R0100-2, Rev.0

Table 4.3. Characteristics of SBS Samples from DM1200 Commissioning Tests (continued).

\begin{tabular}{|c|c|c|c|c|c|c|c|}
\hline Test \# & $\begin{array}{c}\text { Sample Name } \\
- \text { S- = SBS }\end{array}$ & $\mathrm{TSS}(\mathrm{mg} / \mathrm{l})$ & $\mathrm{TDS}(\mathrm{mg} / \mathrm{l})$ & Filtrate $\mathrm{pH}$ & Glass (kg) & $\begin{array}{l}\text { Blowdown } \\
\text { Volume } \\
\text { (gal) }\end{array}$ & $\begin{array}{l}\text { Cumulative } \\
\text { Blowdown } \\
\text { Volume } \\
\text { (gal) }\end{array}$ \\
\hline \multirow{12}{*}{2} & 12E-S-98B & 470 & 1896 & 2.83 & 7900 & 18 & 1084.1 \\
\hline & 12E-S-99A & 482 & 812 & 2.86 & 7950 & 32.3 & 1116.4 \\
\hline & 12E-S-105A & 498 & 1556 & 2.86 & 8200 & 35.5 & 1151.9 \\
\hline & $12 \mathrm{E}-\mathrm{S}-105 \mathrm{~B}$ & 497 & 1676 & 2.82 & 8250 & 32.4 & 1184.3 \\
\hline & 12E-S-109A & 518 & 1786 & 2.86 & 8400 & 23.3 & 1207.6 \\
\hline & 12E-S-109B & 512 & 1572 & 2.83 & 8500 & 32.4 & 1240 \\
\hline & 12E-S-110A & 507 & 1380 & 2.84 & 8550 & 30 & 1270 \\
\hline & 12E-S-118A & 690 & 2270 & 2.59 & 8650 & 27 & 1297 \\
\hline & $12 \mathrm{E}-\mathrm{S}-130 \mathrm{~A}$ & 402 & 2062 & 2.74 & 8650 & 60 & 1357 \\
\hline & $12 \mathrm{E}-\mathrm{S}-130 \mathrm{C}$ & 370 & 1484 & 2.77 & 8650 & 18.1 & 1375.1 \\
\hline & 12E-S-137A & 346 & 1560 & 2.79 & 8700 & 18.7 & 1393.8 \\
\hline & 12E-S-137B & 350 & 1416 & 2.82 & 8700 & 29.2 & 1423 \\
\hline \multirow{18}{*}{3} & $12 \mathrm{E}-\mathrm{S}-137 \mathrm{C}$ & 365 & 1292 & 2.90 & 8700 & 25 & 1448 \\
\hline & 12E-S-138A & 412 & 1340 & 3.01 & 8750 & 27.2 & 1475.2 \\
\hline & 12E-S-138B & 390 & 1480 & 3.09 & 8750 & 34.9 & 1510.1 \\
\hline & $12 \mathrm{E}-\mathrm{S}-139 \mathrm{~A}$ & 512 & 1536 & 3.17 & 8800 & 27.6 & 1537.7 \\
\hline & 12E-S-141A & 518 & 1616 & 3.37 & 8850 & 37.4 & 1575.1 \\
\hline & 12E-S-141B & 555 & 1596 & 3.67 & 8900 & 30.2 & 1605.3 \\
\hline & $12 \mathrm{E}-\mathrm{S}-142 \mathrm{~A}$ & 547 & 1700 & 3.71 & 8950 & 30.1 & 1635.4 \\
\hline & 12E-S-142B & 555 & 1400 & 3.58 & 9000 & 47.9 & 1683.3 \\
\hline & $12 \mathrm{E}-\mathrm{S}-147 \mathrm{~A}$ & 558 & 1404 & 3.54 & 9200 & 34 & 1717.3 \\
\hline & 12E-S-147B & 579 & 1428 & 3.61 & 9250 & 53 & 1770.3 \\
\hline & $12 \mathrm{E}-\mathrm{S}-147 \mathrm{C}$ & 577 & 1512 & 3.60 & 9300 & 35 & 1805.3 \\
\hline & 12E-S-149A & 580 & 1636 & 3.53 & 9350 & 31.9 & 1837.2 \\
\hline & $12 \mathrm{~F}-\mathrm{S}-10 \mathrm{~A}$ & 503 & 1532 & 3.42 & 9400 & 31.7 & 1868.9 \\
\hline & 12F-S-11A & 512 & 1512 & 3.53 & 9500 & 35.1 & 1904 \\
\hline & $12 \mathrm{~F}-\mathrm{S}-13 \mathrm{~A}$ & 500 & 1572 & 3.58 & 9636 & 18.2 & 1922.2 \\
\hline & $12 \mathrm{~F}-\mathrm{S}-14 \mathrm{~A}$ & 453 & 1528 & 3.34 & 9650 & 30 & 1952.2 \\
\hline & $12 \mathrm{~F}-\mathrm{S}-14 \mathrm{~B}$ & 505 & 1520 & 3.31 & 9700 & 29.3 & 1981.5 \\
\hline & $12 \mathrm{~F}-\mathrm{S}-16 \mathrm{~A}$ & 528 & 1452 & 3.46 & 9750 & 34.7 & 2016.2 \\
\hline
\end{tabular}


The Catholic University of America

Vitreous State Laboratory
ORP-51437, ReyrgMelter 1200 Start-Up Tests with AZ-101

Final Report, VSL-01R0100-2, Rev.0

Table 4.3. Characteristics of SBS Samples from DM1200 Commissioning Tests (continued).

\begin{tabular}{|c|c|c|c|c|c|c|c|}
\hline Test \# & $\begin{array}{c}\text { Sample Name } \\
- \text {-S- = SBS }\end{array}$ & $\mathrm{TSS}(\mathrm{mg} / \mathrm{l})$ & $\mathrm{TDS}(\mathrm{mg} / \mathrm{l})$ & Filtrate $\mathrm{pH}$ & Glass (kg) & $\begin{array}{l}\text { Blowdown } \\
\text { Volume } \\
\text { (gal) }\end{array}$ & $\begin{array}{c}\text { Cumulative } \\
\text { Blowdown } \\
\text { Volume } \\
\text { (gal) }\end{array}$ \\
\hline \multirow{11}{*}{3} & $12 \mathrm{~F}-\mathrm{S}-17 \mathrm{~A}$ & 568 & 1412 & 3.47 & 9800 & 10.9 & 2027.1 \\
\hline & $12 \mathrm{~F}-\mathrm{S}-20 \mathrm{~A}$ & 585 & 1600 & 3.77 & 9850 & 38.6 & 2065.7 \\
\hline & $12 \mathrm{~F}-\mathrm{S}-20 \mathrm{~B}$ & 649 & 1448 & 3.99 & 9900 & 41.8 & 2107.5 \\
\hline & $12 \mathrm{~F}-\mathrm{S}-25 \mathrm{~A}$ & 590 & 1508 & 3.75 & 10000 & 45.7 & 2153.2 \\
\hline & $12 \mathrm{~F}-\mathrm{S}-25 \mathrm{~B}$ & 555 & 1452 & 3.64 & 10050 & 45.2 & 2198.4 \\
\hline & $12 \mathrm{~F}-\mathrm{S}-27 \mathrm{~A}$ & 582 & 1584 & 3.68 & 10150 & 42.6 & 2241 \\
\hline & $12 \mathrm{~F}-\mathrm{S}-28 \mathrm{~A}$ & 560 & - & 3.84 & 10200 & 28.6 & 2269.6 \\
\hline & $12 \mathrm{~F}-\mathrm{S}-33 \mathrm{~A}$ & 592 & 1576 & 3.83 & 10300 & 21 & 2290.6 \\
\hline & 12F-S-33B & 573 & 1640 & 3.83 & 10350 & 20 & 2310.6 \\
\hline & $12 \mathrm{~F}-\mathrm{S}-34 \mathrm{~A}$ & 590 & 1528 & 3.79 & 10450 & 37.4 & 2348 \\
\hline & $12 \mathrm{~F}-\mathrm{S}-36 \mathrm{~A}$ & 570 & 1580 & 3.60 & 10549 & 30.2 & 2378.2 \\
\hline
\end{tabular}


The Catholic University of America Vitreous State Laboratory
DuraMelter 1200 Start-Up Tests with AZ-101

Final Report, VSL-01R0100-2, Rev.0

Table 4.4. Analytical Results for Samples of SBS Blowdown Fluids (mg/l).

\begin{tabular}{|c|c|c|c|c|c|c|c|c|c|c|c|c|c|c|c|}
\hline & \multicolumn{3}{|c|}{ 12D-S-109A } & \multicolumn{3}{|c|}{ 12D-S-113A } & \multicolumn{3}{|c|}{ 12D-S-114A } & \multicolumn{3}{|c|}{ 12D-S-115A } & \multicolumn{3}{|c|}{ 12D-S-115B } \\
\hline Glass (kg) & \multicolumn{3}{|c|}{5092} & \multicolumn{3}{|c|}{5092} & \multicolumn{3}{|c|}{5092} & \multicolumn{3}{|c|}{5150} & \multicolumn{3}{|c|}{5175} \\
\hline $\mathrm{pH}$ & \multicolumn{3}{|c|}{2.75} & \multicolumn{3}{|c|}{2.73} & \multicolumn{3}{|c|}{2.75} & \multicolumn{3}{|c|}{2.93} & \multicolumn{3}{|c|}{2.90} \\
\hline & 1s.* ${ }^{*}$ & Dis.\# & Total & Sus. & Dis. & Total & Sus. & Dis. & Total & Sus. & Dis. & tal & us. & Dis. & otal \\
\hline otal & 320 & $\mathrm{NA}$ & 320 & 494 & 2158 & 2652 & 420 & 2156 & 2576 & 500 & 1980 & 2480 & 456 & 2220 & 2676 \\
\hline$\overline{\mathrm{Al}}$ & 7.3 & 52.3 & $\overline{59.6}$ & 2.4 & 52.3 & 54.7 & 7.3 & 50.8 & 58.0 & 14.4 & 51.2 & 65.6 & 5.4 & 50.7 & 56.1 \\
\hline As & $\overline{0.3}$ & 0.9 & 1.2 & 0.1 & $\overline{1.1}$ & 1.2 & 0.1 & 1.1 & 1.2 & 0.2 & 1.1 & 1.3 & 0.3 & 1.1 & 7 \\
\hline 3 & 1.9 & 217.8 & 219.7 & 0.8 & 214.5 & 215.4 & 1.1 & 211.8 & 212.9 & 1.7 & 215.5 & 217.2 & 1.2 & 215.1 & 1216.4 \\
\hline $\mathrm{Ba}$ & $\overline{0.4}$ & 0.3 & $\overline{0.6}$ & 0.1 & 0.2 & 0.3 & 0.5 & $\overline{0.2}$ & 0.7 & 0.5 & 0.2 & 0.8 & 0.6 & 0.2 & 0.8 \\
\hline $\mathrm{Ca}$ & 60.1 & 8.4 & 8.4 & $<0.1$ & 8.9 & 8.9 & 2.0 & 8.8 & 10.8 & 2.6 & 9.0 & 11.6 & 2.2 & 9.0 & $\overline{11.2}$ \\
\hline $\mathrm{Cd}$ & & 7.6 & 8.4 & 3 & 7.3 & 7. & 1.1 & 6.9 & 7.9 & 1.4 & 7.0 & 8. & 1.5 & 6.8 & 8.2 \\
\hline $\mathrm{Cr}$ & 0.9 & 0.4 & 1.4 & 0.4 & 0.5 & 0.8 & 1.3 & $\overline{0.4}$ & 1.7 & 1.5 & 0.4 & 1.8 & 1.5 & $\overline{0.4}$ & 1.9 \\
\hline$\overline{\mathrm{Cs}}$ & $<0.1$ & 7.1 & 7.1 & $<0.1$ & 6.9 & 6.9 & 0.2 & 6.5 & 6.7 & 0.4 & 6.1 & 6.5 & 0.4 & 6.6 & 7.0 \\
\hline $\mathrm{Cu}$ & 0.1 & 0.4 & 0.5 & 0.0 & 0.3 & 0.4 & 0.1 & $\overline{0.3}$ & $\overline{0.4}$ & 0.1 & 0.4 & 0.5 & 0.1 & 0.4 & 0.5 \\
\hline $\mathrm{Fe}$ & 62.5 & 1.5 & 64.0 & 25.7 & $\overline{2.3}$ & 27.9 & 88.7 & 1.6 & $\overline{90.3}$ & 112.4 & 0.8 & 113.1 & 61.2 & 0.9 & \begin{tabular}{l|l}
9 & 62.1
\end{tabular} \\
\hline $\mathbb{K}$ & 0.0 & 1.0 & 11.0 & $<0.1$ & 10.0 & 10.0 & 0.2 & 16.4 & 16.6 & 0.2 & 9.8 & 10.0 & 0.2 & 9.9 & \begin{tabular}{l|l}
9 & 10.2
\end{tabular} \\
\hline$\overline{\mathrm{Li}}$ & .5 & 32.4 & 32.9 & 0.2 & 30.6 & 30.8 & 0.7 & 28.4 & 29.1 & 1.1 & 28.6 & 29.7 & 1.1 & 28.2 & 29.3 \\
\hline $\mathrm{Mg}$ & 2.1 & 1.7 & 3.7 & 0.9 & 1.9 & 2.8 & 0.7 & 2.0 & 2.6 & 0.1 & 2.0 & 2.1 & $<0.1$ & 2.0 & 2.0 \\
\hline $\mathrm{Mn}$ & 2.0 & 6.9 & 8.9 & 0.8 & 6.3 & 7.1 & 2.3 & 6.3 & 8.5 & 3.8 & 6.5 & 10.4 & 3.7 & 6.3 & 10.1 \\
\hline $\mathrm{Na}$ & $\overline{0.8}$ & 128.2 & 129.0 & 0.3 & 118.9 & 119.2 & 1.3 & 115.9 & 117.2 & 2.4 & 118.8 & 121.2 & 2.3 & 116.2 & 2118.5 \\
\hline $\mathrm{Ni}$ & 3.2 & 1.3 & $\overline{4.6}$ & 1.3 & 1.3 & 2. & 4.0 & 1.3 & 5 & 5.4 & 1.3 & 6 & 5.8 & 1.3 & 7.1 \\
\hline & 0.6 & 9 & 1.5 & 0.1 & 0.9 & 1. & 0. & 0.9 & 1.4 & 0.7 & 0.9 & 1.6 & 0.6 & 1.0 & 1.6 \\
\hline $\mathrm{Pb}$ & 1.4 & 0.6 & 2.0 & 0.6 & 0.6 & 1.1 & 2.1 & $\overline{0.5}$ & 2.6 & 2.6 & 0.5 & 3.1 & 2.6 & 0.5 & 3.2 \\
\hline $\mathrm{Sb}$ & 0.5 & 0.3 & 0.7 & 0.1 & 0.3 & 0.3 & 0.7 & 0.3 & 1.0 & 0.7 & 0.3 & 1.1 & 0.7 & 0.4 & 1.1 \\
\hline $\mathrm{Se}$ & 20.3 & 378.7 & 399.0 & 7.7 & 417.9 & 425.6 & 26.9 & 393.3 & 420.2 & 37.8 & 375.8 & 413.6 & 37.6 & 355.2 & 2392.8 \\
\hline $\mathrm{Si}$ & 29.6 & 23.6 & 53.2 & 19.9 & $\overline{22.7}$ & 42.6 & 48.6 & 22.8 & 71.5 & 24.0 & 26.1 & 50.0 & $<0.1$ & 25.6 & 625.6 \\
\hline $\mathrm{Sr}$ & 1 & 37.9 & 39.0 & 0.5 & 35.8 & 36.3 & 2.2 & $\overline{33.2}$ & 35.4 & 2.9 & 34.0 & 36.9 & 3.1 & 33.8 & 36.9 \\
\hline $\mathrm{Te}$ & 10.9 & 5.6 & 16.5 & 4.2 & $\overline{7.6}$ & 11.8 & 15.6 & 6.8 & 22.5 & 19.1 & 4.6 & 23.7 & 20.2 & 4.8 & 25.0 \\
\hline Ti & 0.4 & 0.0 & $\overline{0.4}$ & 0.2 & 0.0 & 0.2 & 0.6 & $<0.1$ & 0.6 & 0.7 & $<0.1$ & 0.7 & 0.8 & $<0.1$ & 0.8 \\
\hline $\mathrm{Zn}$ & 2.2 & 31.4 & 33.6 & 0.9 & 31.5 & 32.5 & 3.2 & 30.1 & 33.3 & 4.2 & 31.9 & 36.0 & 4.5 & 31.7 & 7336.2 \\
\hline $\mathrm{Zr}$ & 4.5 & 1.9 & $\overline{6.3}$ & 1.9 & $\overline{2.1}$ & 4.0 & 5.1 & 2.1 & $\overline{7.2}$ & 9.5 & 1.6 & 11.1 & 8.4 & 1.7 & 10.1 \\
\hline$\overline{\mathrm{Cl}}$ & $\overline{\mathrm{NA}}$ & 133.4 & 133.4 & $\mathrm{NA}$ & 152.8 & 152.8 & $\mathrm{NA}$ & 144.5 & 144.5 & $\mathrm{NA}$ & 132.1 & 132.1 & $\mathrm{NA}$ & 125.8 & 125.8 \\
\hline F & NA & 90.1 & 90.1 & NA & 97.9 & 97.9 & NA & 96.6 & 96.6 & NA & 96.6 & 96.6 & NA & 92.7 & 92.7 \\
\hline & $<0.1$ & 1.1 & $<0.1$ & $<0.1$ & $\overline{1.4}$ & 1.4 & $<0.1$ & 1.2 & 1.2 & $<0.1$ & 26.8 & 26.8 & $<0.1$ & 29.8 & \begin{tabular}{l|l}
829.8 \\
8
\end{tabular} \\
\hline Nitra & NA & 244.7 & 244.7 & $\mathrm{NA}$ & 225.9 & 225.9 & $\mathrm{NA}$ & 213.8 & 213.8 & $\mathrm{NA}$ & 216.0 & 216.0 & $\mathrm{NA}$ & 204.9 & 204.9 \\
\hline Nitrit & $\mathrm{NA}$ & $<0.1$ & $<0.1$ & $\mathrm{NA}$ & $\mathrm{NA}$ & $\mathrm{NA}$ & $\mathrm{NA}$ & $<0.1$ & $\mathrm{NA}$ & $\mathrm{NA}$ & $<0.1$ & $\mathrm{NA}$ & $\mathrm{NA}$ & $<0.1$ & $\overline{\mathrm{NA}}$ \\
\hline Sulfate & $<0.1$ & 116.5 & 116.5 & $<0.1$ & 126.9 & 126.9 & 1.9 & 117.4 & 119.3 & 1.9 & 112.2 & 114. & 2.0 & 111.3 & 13 . \\
\hline
\end{tabular}

S* - Suspended

D\# - Dissolved 
The Catholic University of America

Vitreous State Laboratory
DuraMelter 1200 Start-Up Tests with AZ-101

Final Report, VSL-01R0100-2, Rev.0

Table 4.4. Analytical Results for Samples of SBS Blowdown Fluids (mg/l). (continued).

\begin{tabular}{|c|c|c|c|c|c|c|c|c|c|c|c|c|}
\hline & \multicolumn{3}{|c|}{ 12D-S-116A } & \multicolumn{3}{|c|}{ 12D-S-121A } & \multicolumn{3}{|c|}{ 12D-S-121B } & \multicolumn{3}{|c|}{ 12D-S-128A } \\
\hline Glass (kg) & \multicolumn{3}{|c|}{5200} & \multicolumn{3}{|c|}{5450} & \multicolumn{3}{|c|}{5500} & \multicolumn{3}{|c|}{5670} \\
\hline $\mathrm{pH}$ & \multicolumn{3}{|c|}{2.90} & \multicolumn{3}{|c|}{2.93} & \multicolumn{3}{|c|}{3.04} & \multicolumn{3}{|c|}{3.09} \\
\hline & Sus.* & Dis.\# & Total & Sus. & Dis. & Total & Sus. & Dis. & Total & Sus. & Dis. & Total \\
\hline Total & 480 & 2090 & 2570 & 382 & 2020 & 2402 & 423 & 1738 & 2161 & 413 & 1705 & 2118 \\
\hline$\overline{\mathrm{Al}}$ & 14.6 & 50.6 & 65.2 & 2.0 & 46.26 & 48.2 & 9.5 & 47.3 & 56.7 & 8.8 & 46.2 & 55.0 \\
\hline As & 0.2 & 1.1 & 1.3 & 0.2 & 1.15 & 1.3 & 0.3 & 0.9 & 1.2 & 0.3 & 1.0 & 1.3 \\
\hline$B$ & 1.0 & 204.4 & 205.4 & 0.8 & 194.81 & 195.6 & 0.7 & 192.8 & 193.5 & 0.7 & 193.0 & 193.6 \\
\hline $\mathrm{Ba}$ & 0.5 & 0.2 & 0.7 & 0.4 & 0.19 & 0.6 & 0.3 & 0.2 & 0.5 & 0.3 & 0.2 & 0.5 \\
\hline $\mathrm{Ca}$ & 3.2 & 8.2 & 11.4 & 2.8 & 8.59 & 11.4 & 0.2 & 8.2 & 8.4 & 0.2 & 7.8 & 8.0 \\
\hline $\mathrm{Cd}$ & 1.2 & 6.4 & 7.5 & 1.0 & 5.54 & 6.5 & 1.0 & 5.5 & 6.5 & 0.9 & 5.3 & 6.3 \\
\hline $\mathrm{Cr}$ & 1.2 & 0.4 & 1.6 & 1.1 & 0.39 & 1.5 & 0.9 & 0.4 & 1.3 & 0.8 & 0.4 & 1.2 \\
\hline $\mathrm{Cs}$ & 0.4 & 6.1 & 6.5 & 0.3 & & 0.3 & 0.6 & 5.6 & 6.2 & $<0.1$ & 6.2 & 6.2 \\
\hline $\mathrm{Cu}$ & 0.1 & 0.3 & 0.4 & 0.1 & 0.32 & 0.4 & 0.1 & 0.3 & 0.4 & 0.1 & 0.3 & 0.4 \\
\hline $\mathrm{Fe}$ & 103.9 & 0.9 & 104.8 & 81.6 & 0.95 & 82.5 & 89.0 & 0.5 & 89.5 & 86.9 & 0.5 & 87.4 \\
\hline $\bar{K}$ & 0.3 & 9.7 & 10.0 & 0.2 & 10.2 & 10.4 & 0.2 & 8.8 & 9.0 & 0.1 & 9.9 & 10.0 \\
\hline $\mathrm{Li}$ & 0.9 & 27.4 & 28.3 & 0.8 & 27.69 & 28.5 & 0.5 & 27.7 & 28.2 & 0.5 & 27.5 & 27.9 \\
\hline $\mathrm{Mg}$ & 2.1 & 1.9 & 4.0 & $<0.1$ & 1.69 & 1.7 & 0.1 & 1.6 & 1.7 & 0.1 & 1.5 & 1.6 \\
\hline $\mathrm{Mn}$ & 3.2 & 6.0 & 9.2 & 2.4 & 5.75 & 8.1 & 2.4 & 5.9 & 8.3 & 2.2 & 5.7 & 8.0 \\
\hline$\overline{\mathrm{Na}}$ & 1.7 & 109.9 & 111.6 & 1.4 & 100.36 & 101.8 & 0.9 & 100.6 & 101.5 & 0.8 & 101.8 & 102.6 \\
\hline$\overline{\mathrm{Ni}}$ & 4.6 & 1.3 & 5.9 & 3.8 & 1.23 & 5.1 & 4.1 & 1.2 & 5.4 & 4.0 & 1.2 & 5.2 \\
\hline $\mathrm{P}$ & 0.6 & 0.9 & 1.6 & 0.4 & 0.82 & 1.3 & 0.5 & 0.7 & 1.2 & 0.5 & 0.8 & 1.2 \\
\hline$\overline{\mathrm{Pb}}$ & 2.1 & 0.5 & 2.6 & 1.8 & 0.42 & 2.2 & 1.8 & 0.4 & 2.2 & 1.7 & 0.4 & 2.1 \\
\hline $\mathrm{Sb}$ & 0.7 & 0.4 & 1.0 & 0.7 & 0.23 & 0.9 & 1.0 & 0.2 & 1.2 & 1.0 & 0.2 & 1.2 \\
\hline $\mathrm{Se}$ & 29.3 & \begin{tabular}{|l|}
348.9 \\
\end{tabular} & 378.2 & 25.2 & 324.52 & 349.7 & 26.4 & 298.3 & 324.7 & 24.4 & 297.7 & 322.1 \\
\hline $\mathrm{Si}$ & 43.3 & 26.7 & 70.0 & 43.1 & 22.36 & 65.4 & 67.8 & 21.1 & 89.0 & 64.4 & 19.7 & 84.1 \\
\hline $\mathrm{Sr}$ & 2.4 & 32.7 & 35.1 & 1.9 & 31.14 & 33.0 & 1.3 & 31.2 & 32.5 & 1.2 & 30.6 & 31.8 \\
\hline $\mathrm{Te}$ & 15.7 & 4.7 & 20.4 & 13.4 & 4.23 & 17.6 & 14.0 & 3.4 & 17.3 & 13.2 & 3.4 & 16.6 \\
\hline $\mathrm{Ti}$ & 0.7 & $<0.1$ & 0.7 & 0.5 & 0.03 & 0.6 & 0.4 & $<0.1$ & 0.4 & 0.4 & $<0.1$ & 0.4 \\
\hline $\mathrm{Zn}$ & 3.5 & 30.8 & 34.3 & 2.9 & 27.64 & 30.6 & 3.0 & 26.7 & 29.6 & 2.7 & 26.3 & 29.0 \\
\hline$\overline{\mathrm{Zr}}$ & 6.5 & 1.8 & 8.4 & 4.6 & 1.66 & 6.3 & 6.5 & 1.3 & 7.8 & 6.2 & 1.3 & 7.5 \\
\hline $\mathrm{Cl}$ & $\mathrm{NA}$ & 132.1 & 132.1 & NA & 90.8 & 90.8 & NA & 86.6 & 86.6 & NA & 86.63 & 86.6 \\
\hline$F$ & $\mathrm{NA}$ & 89.4 & 89.4 & NA & 89.7 & 89.7 & NA & 86.7 & 86.7 & NA & 86.07 & 86.1 \\
\hline I & $<0.1$ & 27.8 & 27.8 & $<0.1$ & 18.4 & 18.4 & $<0.1$ & 23.1 & 23.1 & $<0.1$ & 23.8 & 23.8 \\
\hline Nitrate & NA & 244.7 & 244.7 & NA & 210.2 & 210.2 & NA & 205.7 & 205.7 & NA & 212.42 & 212.4 \\
\hline Nitrite & $\mathrm{NA}$ & $<0.1$ & $<0.1$ & NA & $<0.1$ & $<0.1$ & NA & $<0.1$ & $<0.1$ & NA & $<0.1$ & $<0.1$ \\
\hline Sulfate & 0.9 & 117.4 & 118.3 & 1.6 & 310.4 & 312.1 & 2.1 & 285.8 & 287.9 & 2.6 & 287 & 289.6 \\
\hline
\end{tabular}


The Catholic University of America Vitreous State Laboratory
DuraMelter 1200 Start-Up Tests with AZ-101

Final Report, VSL-01R0100-2, Rev.0

Table 4.4. Analytical Results for Samples of SBS Blowdown Fluids (mg/l). (continued).

\begin{tabular}{|c|c|c|c|c|c|c|c|c|c|c|c|c|c|c|c|}
\hline & \multicolumn{3}{|c|}{ 12D-S-129A } & \multicolumn{3}{|c|}{ 12D-S-129B } & \multicolumn{3}{|c|}{ 12D-S-132A } & \multicolumn{3}{|c|}{$12 \mathrm{D}-\mathrm{S}-137 \mathrm{~A}$} & \multicolumn{3}{|c|}{ 12D-S-140A } \\
\hline Glass (kg) & \multicolumn{3}{|c|}{5720} & \multicolumn{3}{|c|}{5770} & \multicolumn{3}{|c|}{5870} & \multicolumn{3}{|c|}{6050} & \multicolumn{3}{|c|}{6153} \\
\hline $\mathrm{pH}$ & \multicolumn{3}{|c|}{3.08} & \multicolumn{3}{|c|}{3.04} & \multicolumn{3}{|c|}{2.95} & \multicolumn{3}{|c|}{2.90} & \multicolumn{3}{|c|}{2.87} \\
\hline & Sus. * & Dis.\# & Total & Sus. & Dis. & Total & \begin{tabular}{|l} 
Sus. \\
\end{tabular} & \begin{tabular}{|l} 
Dis. \\
.
\end{tabular} & Total & $\overline{\text { Sus. }}$ & Dis. & Total & \begin{tabular}{|l|} 
Sus. \\
\end{tabular} & Dis. & Total \\
\hline Total & 363 & 1208 & 1571 & 360 & 1573 & 1933 & 317 & 1603 & 1920 & 312 & 1250 & 1562 & 290 & 1212 & 21502 \\
\hline $\mathrm{Al}$ & 7.4 & 43.9 & 51.3 & 7.0 & $\overline{43.4}$ & 50.4 & 5.7 & 41.1 & 46.7 & 5.0 & 40.4 & 45.4 & 4.6 & 37.3 & 41.9 \\
\hline $\mathrm{As}$ & 0.3 & 1.0 & 1.3 & $\overline{0.3}$ & 1.0 & 1.4 & 0.3 & 0.8 & 1.1 & 0.2 & 0.9 & 1.1 & 0.3 & 0.8 & 1.0 \\
\hline $\mathrm{B}$ & 0.6 & 189.3 & 89.8 & 0.6 & 193.0 & 193.6 & 0.5 & 182.7 & 183.1 & 0.5 & 173.8 & 174.3 & 0.4 & 168.5 & 168.9 \\
\hline$\overline{\mathrm{Ba}}$ & 0.3 & $\overline{0.2}$ & 0.5 & 0.3 & 0.2 & 0.5 & 0.2 & 0.2 & 0.4 & 0.2 & 0.2 & 0.4 & 0.2 & 0.2 & 0.4 \\
\hline $\mathrm{Ca}$ & 0.1 & 7.6 & 7.7 & 0.2 & 7.4 & 7.5 & 0.1 & 7.0 & 7.1 & 0.1 & 6.6 & 6.7 & 0.1 & 6.1 & 6.2 \\
\hline $\mathrm{Cd}$ & 0.9 & 5.3 & 6.2 & 0.8 & 5.2 & 6.0 & 0.7 & 4.9 & 5.6 & 0.7 & 5.0 & 5.6 & 0.6 & 4.7 & 5.4 \\
\hline $\mathrm{Cr}$ & 0.8 & 0.4 & 1.1 & 0.8 & $\overline{0.4}$ & 1.1 & 0.7 & 0.4 & 1.1 & 0.7 & 0.4 & 1.0 & 0.6 & 0.4 & 1.0 \\
\hline$\overline{C s}$ & 0.1 & 6.3 & 6.3 & 0.5 & $\overline{5.8}$ & 6.3 & $<0.1$ & 5.5 & 5.5 & $<0.1$ & 5.2 & 5.2 & $<0.1$ & 4.8 & 4.8 \\
\hline $\mathrm{Cu}$ & 0.1 & 0.3 & 0.4 & 0.1 & 0.3 & 0.4 & 0.1 & 0.3 & 0.3 & 0.1 & 0.3 & 0.3 & 0.1 & 0.3 & 0.3 \\
\hline $\mathrm{Fe}$ & 81.8 & 0.6 & 82.4 & 80.3 & 0.7 & 81.0 & 72.4 & 1.2 & 73.6 & 69.0 & 1.2 & 70.2 & 65.1 & 1.4 & 66.5 \\
\hline $\mathrm{K}$ & 0.1 & 9.7 & 9.8 & 0.1 & 9.1 & 9.2 & 0.1 & 8.5 & 8.6 & 0.1 & 7.9 & 8.0 & 0.1 & 7.3 & 7.4 \\
\hline $\mathrm{Li}$ & 0.4 & 26.9 & 27.3 & $\overline{0.4}$ & $\overline{25.1}$ & 25.5 & 0.4 & 23.1 & 23.5 & 0.3 & 22.5 & 22.8 & 0.3 & 20.4 & 20.7 \\
\hline $\mathrm{Mg}$ & 0.1 & 1.5 & 1.6 & 0.1 & 1.4 & 1.5 & 0.1 & 1.4 & 1.5 & 0.1 & 1.3 & 1.4 & 0.1 & 1.2 & 1.3 \\
\hline $\mathrm{Mn}$ & 1.9 & 5.5 & 7.4 & 1.8 & 5.3 & 7.1 & 1.6 & 5.1 & 6.7 & 1.7 & 5.0 & 6.7 & 1.7 & 4.8 & 6.5 \\
\hline $\mathrm{Na}$ & 0.7 & 98.6 & 99.3 & 0.7 & 95.0 & 95.7 & 0.6 & 88.6 & 89.2 & 0.5 & 82.8 & 83.3 & 0.5 & 78.2 & 78.7 \\
\hline $\mathrm{Ni}$ & 3.6 & 1.2 & 4.8 & 3.6 & $\overline{1.1}$ & 4.8 & 3.2 & 1.1 & 4.3 & 3.2 & 1.1 & 4.2 & 3.0 & 1.0 & 4.0 \\
\hline $\mathrm{P}$ & 0.5 & 0.8 & 1.3 & 0.4 & 0.8 & 1.2 & 0.4 & 0.7 & 1.1 & 0.5 & 0.8 & 1.3 & $\overline{0.4}$ & 0.6 & 1.0 \\
\hline $\mathrm{Pb}$ & 1.6 & 0.4 & 1.9 & 1.5 & $\overline{0.4}$ & 1.9 & 1.4 & 0.4 & 1.8 & 1.3 & 0.3 & 1.7 & 1.3 & 0.3 & 1.6 \\
\hline $\mathrm{Sb}$ & 0.9 & 0.2 & 1.1 & 0.8 & 0.1 & 0.9 & 0.8 & 0.3 & 1.1 & 0.6 & 0.3 & 0.8 & 0.7 & 0.3 & 0.9 \\
\hline $\mathrm{Se}$ & 22.8 & 293.4 & 316.2 & 23.4 & 285.2 & 308.6 & 19.4 & 270.7 & 290.2 & 19.0 & 274.4 & 293.4 & 18.1 & 249.7 & 267.7 \\
\hline $\mathrm{Si}$ & 58.5 & 19.7 & 78.2 & 57.4 & 18.9 & 76.3 & 48.9 & 18.1 & 67.0 & 52.2 & 17.4 & 69.6 & 46.5 & 16.5 & 63.0 \\
\hline $\mathrm{Sr}$ & 1.1 & 29.3 & 30.3 & 1.0 & 28.3 & 29.3 & 0.9 & 26.2 & 27.0 & 0.8 & 25.3 & 26.1 & 0.7 & 23.2 & 23.8 \\
\hline $\mathrm{Te}$ & 12.5 & 3.2 & 15.7 & 12.0 & 3.5 & 15.5 & 11.1 & 4.1 & 15.3 & 11.0 & 4.0 & 15.0 & 10.2 & 4.1 & 14.3 \\
\hline Ti & 0.4 & $<0.1$ & 0.4 & 0.4 & $<0.1$ & 0.4 & 0.3 & $<0.1$ & 0.3 & 0.3 & $<0.1$ & 0.3 & 0.3 & $<0.1$ & 0.3 \\
\hline $\mathrm{Zn}$ & 2.5 & 25.5 & 28.0 & 2.5 & 24.3 & 26.7 & 2.1 & 22.8 & 24.9 & 2.1 & 21.7 & 23.9 & 2.0 & 20.7 & 22.7 \\
\hline $\mathrm{Zr}$ & 4.8 & 1.5 & 6.2 & 4.3 & 1.6 & 6.0 & 3.7 & 2.0 & 5.7 & 3.8 & 2.1 & 5.8 & 3.5 & 2.2 & 5.6 \\
\hline $\mathrm{Cl}$ & $\mathrm{NA}$ & 84.6 & 84.6 & $\mathrm{NA}$ & 82.4 & 82.4 & $\mathrm{NA}$ & 80.4 & 80.4 & $\mathrm{NA}$ & 89.8 & 89.8 & $\mathrm{NA}$ & 75.7 & 75.7 \\
\hline 而 & NA & 80.5 & 80.5 & NA & 80.0 & 80.0 & $\overline{\mathrm{NA}}$ & 82.8 & 82.8 & $\mathrm{NA}$ & 94.0 & 94.0 & $\overline{\mathrm{NA}}$ & 76.5 & 76.5 \\
\hline & $<0.1$ & 23.5 & 23.5 & $<0.1$ & 26.5 & 26.5 & $<0.1$ & 27.2 & 27.2 & $<0.1$ & 17.8 & 17.8 & $<0.1$ & 17.0 & 17.0 \\
\hline Nitrate & $\mathrm{NA}$ & 207.9 & 207.9 & NA & 198.68 & 198.7 & NA & 196.61 & 196.6 & NA & 213.55 & 213.6 & NA & 179.16 & 179.2 \\
\hline Nitrite & NA & $<0.1$ & $<0.1$ & NA & $<0.1$ & $<0.1$ & NA & $<0.1$ & $<0.1$ & NA & $<0.1$ & $<0.1$ & NA & $<0.1$ & $<0.1$ \\
\hline Sulfate & 1.6 & 277.13 & 278.7 & 1.8 & 268.53 & 270.3 & & 263.57 & 264.6 & 2.4 & 283.3 & 285.7 & 1.2 & 236.09 & 237.3 \\
\hline
\end{tabular}


The Catholic University of America Vitreous State Laboratory
DuraMelter 1200 Start-Up Tests with AZ-101

Final Report, VSL-01R0100-2, Rev.0

Table 4.4. Analytical Results for Samples of SBS Blowdown Fluids (mg/l). (continued).

\begin{tabular}{|c|c|c|c|c|c|c|c|c|c|c|c|c|c|c|c|}
\hline & \multicolumn{3}{|c|}{ 12D-S-142A } & \multicolumn{3}{|c|}{ 12D-S-151A } & \multicolumn{3}{|c|}{$12 \mathrm{E}-\mathrm{S}-17 \mathrm{~A}$} & \multicolumn{3}{|c|}{$12 \mathrm{E}-\mathrm{S}-24 \mathrm{~A}$} & \multicolumn{3}{|c|}{$12 \mathrm{E}-\mathrm{S}-38 \mathrm{~A}$} \\
\hline Glass (kg) & \multicolumn{3}{|c|}{6153} & \multicolumn{3}{|c|}{6250} & \multicolumn{3}{|c|}{6300} & \multicolumn{3}{|c|}{6400} & \multicolumn{3}{|c|}{6550} \\
\hline $\mathrm{oH}$ & \multicolumn{3}{|c|}{2.84} & \multicolumn{3}{|c|}{2.88} & \multicolumn{3}{|c|}{2.87} & \multicolumn{3}{|c|}{2.81} & \multicolumn{3}{|c|}{2.91} \\
\hline & Sus. ${ }^{*}$ & Dis.\# & Total & Sus. & Dis. & Total & Sus. & Dis. & Total & Sus. & Dis. & Total & Sus. & Dis. & Total \\
\hline Total & 265 & 1214 & 1479 & 290 & 1206 & 1496 & 234 & 1476 & 1710 & 214 & 1290 & 1504 & 192 & 1112 & 1304 \\
\hline $\mathrm{Al}$ & 4.3 & 36.7 & 41.0 & 4.5 & 35.8 & 40.3 & 7.7 & 33.83 & 41.6 & 5.5 & 32.82 & 38.4 & 2.9 & 32.8 & 35.7 \\
\hline As & 0.2 & 0.8 & 1.0 & 0.2 & 0.8 & 1.0 & 0.1 & 1.06 & 1.2 & 0.1 & 0.88 & 0.9 & 0.1 & 0.8 & 0.9 \\
\hline$B$ & 0.4 & 167.1 & 167.5 & 0.4 & 158.6 & 159.0 & 0.5 & 55.97 & 156.5 & 0.3 & 53.92 & 154.2 & 0.3 & 157.2 & 57.5 \\
\hline$\overline{\mathrm{Ba}}$ & 0.2 & 0.2 & 0.4 & 0.2 & 0.2 & 0.4 & 0.3 & 0.25 & 0.5 & 0.2 & 0.25 & 0.5 & 0.1 & $\overline{0.3}$ & 0.4 \\
\hline $\mathrm{Ca}$ & 0.1 & 5.9 & 6.0 & 0.1 & 5.7 & 5.8 & 2.3 & 5.56 & 7.8 & 3.5 & 5.48 & 9.0 & 0.1 & 5.3 & 5.4 \\
\hline $\mathrm{Cd}$ & 0.6 & 4.7 & 5.2 & 0.6 & 4.3 & 4.9 & 0.7 & 4.13 & 4.9 & 0.6 & 3.91 & 4.5 & 0.4 & 3.9 & 4.3 \\
\hline $\mathrm{Cr}$ & 0.6 & $\overline{0.4}$ & 1.0 & 0.6 & 0.4 & 1.0 & 0.8 & 0.35 & 1.2 & 0.7 & 0.34 & 1.0 & 0.4 & 0.3 & 0. \\
\hline Cs & $<0.1$ & 4.6 & 4.6 & $<0.1$ & 4.3 & 4.3 & $<0.1$ & 4.2 & 4.2 & $<0.1$ & 4.1 & 4.1 & 0.3 & 3.9 & 1. \\
\hline $\mathrm{Cu}$ & 0.1 & 0.2 & 0.3 & 0.1 & 0.2 & 0.3 & 0.1 & 0.23 & 0.3 & 0.1 & 0.22 & 0.3 & $<0.1$ & 0.2 & 0. \\
\hline $\mathrm{Fe}$ & 63.2 & 1.4 & 64.6 & 62.7 & 1.3 & 64.0 & 76.3 & 1.55 & 77.9 & 60.7 & 1.77 & 62.5 & 46.4 & 1.4 & 47.8 \\
\hline K & 0.1 & 7.0 & 7.1 & 0.1 & 6.6 & 6.7 & $<0.1$ & 6.19 & 6.2 & $<0.1$ & 11.26 & 11.3 & 0.1 & 5.6 & 5.7 \\
\hline $\mathrm{Li}$ & 0.3 & 19.7 & 20.0 & 0.3 & 18.1 & 18.4 & 0.5 & 18.12 & 18.7 & 0.5 & 17.14 & 17.6 & 0.2 & 17.3 & 17. \\
\hline $\mathrm{Mg}$ & 0.1 & 1.1 & 1.2 & 0.1 & 1.1 & 1.2 & 2.4 & 1.03 & 3.4 & 2.0 & & 3.0 & 0.1 & 1.0 & 1. \\
\hline $\mathrm{Mn}$ & 1.5 & 4.7 & 6.2 & 1.9 & 4.7 & 6.6 & 1.9 & 4.73 & 6.7 & 1.6 & 4.77 & 6.4 & 0.8 & 4.9 & 5.8 \\
\hline $\mathrm{Na}$ & 0.5 & 76.8 & 77.2 & 0.5 & 71.5 & 72.0 & 0.8 & 69.42 & 70.3 & 0.7 & 67.46 & 68.2 & 0.3 & 69.2 & 69.5 \\
\hline $\mathrm{Ni}$ & 2.9 & 1.0 & 3.9 & 3.0 & 1.0 & 3.9 & 3.8 & 0.94 & 4.7 & 3.1 & 0.93 & 4.0 & 2.2 & 0.9 & 3.1 \\
\hline $\mathrm{P}$ & 0.3 & 0.6 & 0.9 & 0.4 & 0.7 & 1.1 & 0.5 & 0.53 & 1.0 & 0.3 & 0.6 & 0.9 & 0.2 & 0.6 & 0.8 \\
\hline $\mathrm{Pb}$ & 1.2 & 0.3 & 1.5 & 1.2 & 0.3 & 1.5 & 1.6 & 0.34 & 2.0 & 1.3 & 0.32 & 1.6 & 0.9 & 0.3 & 1. \\
\hline $\mathrm{Sb}$ & 0.5 & 0.2 & 0.6 & 0.5 & 0.2 & 0.6 & 0.3 & 0.14 & 0.5 & 0.1 & 0.16 & 0.3 & 0.4 & 0.2 & 0.6 \\
\hline $\mathrm{Se}$ & 15.3 & 255.0 & 270.2 & 17.1 & 268.2 & 285.3 & 19.2 & 267.09 & 286.3 & 15.3 & 244.16 & 259.4 & 11.5 & 253.9 & 265.4 \\
\hline $\mathrm{Si}$ & 43.4 & 15.9 & 59.3 & 49.5 & 15.1 & 64.6 & 9.2 & 14.57 & 23.8 & 16.4 & \begin{tabular}{|l|}
14.17 \\
\end{tabular} & 30.6 & 28.6 & 13.5 & 42.1 \\
\hline $\mathrm{Sr}$ & 0.7 & 22.9 & 23.5 & 0.6 & 22.4 & 23.0 & 1.2 & 22.18 & 23.3 & 0.9 & 20.97 & 21.9 & 0.4 & 21.0 & 21.4 \\
\hline$\Gamma \mathrm{e}$ & 9.5 & 3.9 & 13.4 & 9.4 & 3.4 & 12.8 & 10.6 & 3.78 & 14.4 & 8.1 & 3.91 & 12.0 & 5.7 & 3.1 & 8. \\
\hline Гi & 0.3 & $<0.1$ & 0.3 & 0.3 & $<0.1$ & 0.3 & 0.6 & $<0.1$ & 0.6 & 0.5 & $<0.1$ & 0.5 & 0.3 & $<0.1$ & 0.3 \\
\hline $\mathrm{Zn}$ & 1.8 & 20.1 & 22.0 & 1.9 & 19.4 & 21.2 & 2.3 & 19.22 & 21.5 & 1.8 & 18.8 & 20.6 & 1.3 & 18.8 & 20.1 \\
\hline $\mathrm{Zr}$ & 2.9 & 2.2 & 5.1 & 3.6 & 2.3 & 5.9 & 3.8 & 2.04 & 5.8 & 3.1 & 2.08 & 5.2 & 1.9 & 2.1 & 4.0 \\
\hline $\mathrm{Cl}$ & NA & 73.7 & 73.7 & NA & 70.2 & 70.2 & $\mathrm{NA}$ & 89.4 & 89.4 & $\mathrm{NA}$ & 95.5 & 95.5 & NA & 87.3 & 87.3 \\
\hline $\mathrm{F}$ & NA & 74.1 & 74.1 & $\mathrm{NA}$ & 73.1 & 73.1 & $\mathrm{NA}$ & 74.7 & 74.7 & $\mathrm{NA}$ & 73.4 & 73.4 & $\mathrm{NA}$ & 71.7 & 71.7 \\
\hline & $<0.1$ & 10.1 & 10.1 & $<0.1$ & 11.7 & 11.7 & $<0.1$ & 9.2 & 9.2 & $<0.1$ & 11.2 & 11.2 & $<0.1$ & 9.2 & 9.1 \\
\hline Nitrate & NA 1 & 179.16 & 179.2 & NA & 181.71 & 181.7 & NA & \begin{tabular}{|l|}
178.9 \\
\end{tabular} & 178.9 & NA & 180.6 & 180.6 & NA & 182.24 & 182.2 \\
\hline Nitrite & NA & $<0.1$ & $<0.1$ & NA & $<0.1$ & $<0.1$ & $\mathrm{NA}$ & $<0.1$ & $<0.1$ & NA & $<0.1$ & 0.0 & NA & $<0.1$ & $<0.1$ \\
\hline Sulfate & 0.32 & 225.89 & 226.2 & $<0.1$ & 214.77 & 214.8 & $<0.1$ & \begin{tabular}{|l|}
213.4 \\
\end{tabular} & 213.4 & 1.4 & 201.3 & 202.7 & 0.4 & 187.29 & 187. \\
\hline
\end{tabular}


The Catholic University of America Vitreous State Laboratory
DuraMelter 1200 Start-Up Tests with AZ-101

Final Report, VSL-01R0100-2, Rev.0

Table 4.4. Analytical Results for Samples of SBS Blowdown Fluids (mg/l). (continued).

\begin{tabular}{|c|c|c|c|c|c|c|c|c|c|c|c|c|c|c|c|}
\hline & \multicolumn{3}{|c|}{$12 \mathrm{E}-\mathrm{S}-49 \mathrm{~A}$} & \multicolumn{3}{|c|}{$12 \mathrm{E}-\mathrm{S}-69 \mathrm{~A}$} & \multicolumn{3}{|c|}{$12 \mathrm{E}-\mathrm{S}-76 \mathrm{~A}$} & \multicolumn{3}{|c|}{$12 \mathrm{E}-\mathrm{S}-77 \mathrm{~A}$} & \multicolumn{3}{|c|}{$12 \mathrm{E}-\mathrm{S}-78 \mathrm{~A}$} \\
\hline Glass (kg) & \multicolumn{3}{|c|}{6679} & \multicolumn{3}{|c|}{6679} & \multicolumn{3}{|c|}{6720} & \multicolumn{3}{|c|}{6800} & \multicolumn{3}{|c|}{7000} \\
\hline $\mathrm{pH}$ & \multicolumn{3}{|c|}{2.93} & \multicolumn{3}{|c|}{3.00} & \multicolumn{3}{|c|}{2.97} & \multicolumn{3}{|c|}{2.85} & \multicolumn{3}{|c|}{2.95} \\
\hline & us.* * & Dis.\# & Total & Sus. & Dis. & Total & Sus. & Dis. & Total & Sus. & Dis. & Total & Sus. & Dis. & Total \\
\hline Total & 270 & 1216 & 1486 & 301 & 1148 & 1449 & 223 & 1074 & 1297 & 233 & 838 & 1071 & 312 & 1296 & 160 \\
\hline $\mathrm{Al}$ & 6.9 & 32.9 & 39.8 & 6.1 & 34.0 & 40.0 & 3.9 & 31.0 & 34.9 & 4.5 & 31.3 & 35.8 & 7.4 & 33.7 & 41. \\
\hline As & 0.2 & 0.79 & 1.0 & $\overline{0.1}$ & 0.7 & 0.8 & 0.2 & 0.7 & 0.8 & 0.2 & 0.8 & 1.0 & $\overline{0.2}$ & 0.9 & 1 \\
\hline$B$ & 0.0 & 144.9 & 44.9 & 0.5 & 151.2 & 151.7 & 0.3 & 142.9 & 143.2 & 0.4 & 144.1 & 144.5 & $\overline{0.4}$ & 153.1 & 153.6 \\
\hline $\mathrm{Ba}$ & 0.3 & 0.27 & 0.5 & 0.1 & 0.3 & 0.4 & 0.1 & 0.3 & 0.4 & 0.1 & 0.3 & 0.4 & 0.1 & 0.3 & 0. \\
\hline $\mathrm{Ca}$ & 4.8 & $\overline{5.47}$ & 10.3 & $\overline{0.2}$ & 6.7 & 6.9 & 0.1 & 5.4 & 5.6 & 0.1 & 5.8 & 5.9 & 0.1 & 6.0 & U. \\
\hline $\mathrm{Cd}$ & 0.7 & 3.88 & 4.6 & 0.5 & 3.8 & 4.4 & 0.5 & 3.5 & 3.9 & 0.5 & 3.6 & 4.0 & $\overline{0.6}$ & 4.0 & 4. \\
\hline $\mathrm{Cr}$ & 0.8 & 0.28 & 1.1 & 0.5 & 0.3 & 0.8 & 0.4 & 0.3 & 0.7 & 0.4 & 0.3 & 0.7 & 0.5 & 0.3 & 0 . \\
\hline $\mathrm{Cs}$ & $<0.1$ & 3.5 & 3.5 & $\overline{0.4}$ & 3.5 & 3.9 & 0.2 & 3.3 & 3.5 & 0.2 & 3.3 & 3.5 & 0.5 & 3.7 & 4 \\
\hline $\mathrm{Cu}$ & 0.1 & 0.22 & 0.3 & 0.1 & 0.2 & 0.3 & 0.0 & 0.2 & 0.2 & 0.1 & 0.2 & 0.3 & 0.1 & 0.2 & 8 \\
\hline $\mathrm{Fe}$ & 83.3 & 1.08 & 84.4 & 61.3 & 0.8 & 62.1 & 51.1 & 1.3 & 52.4 & 54.7 & 1.9 & 56.6 & 66.2 & 1.5 & 67. \\
\hline $\mathrm{K}$ & 0.1 & 5.44 & 5.6 & $\overline{0.1}$ & 5.5 & 5.5 & 0.1 & 4.9 & 5.0 & 0.1 & 5.0 & 5.0 & $\overline{0.1}$ & 5.4 & ( \\
\hline $\mathrm{Li}$ & 0.6 & 17.24 & 17.8 & 0.3 & 18.1 & 18.4 & 0.2 & 16.0 & 16.2 & 0.2 & 16.1 & 16.3 & $\overline{0.3}$ & 17.8 & 18 \\
\hline $\mathrm{Mg}$ & 0.8 & 0.96 & 1.8 & $\overline{0.1}$ & 1.2 & 1.3 & 0.1 & 1.0 & 1.1 & 0.1 & 1.1 & 1.2 & 0.1 & 1.1 & 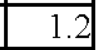 \\
\hline $\mathrm{Mn}$ & 2.6 & 4.96 & 7.5 & 2.0 & 5.3 & 7.3 & 1.1 & 4.9 & 6.0 & 1.2 & 5.0 & 6.2 & 1.6 & 5.5 & 7. \\
\hline $\mathrm{Na}$ & 0.9 & 67.76 & 68.7 & 1.0 & 72.7 & 73.7 & 0.5 & 65.5 & 66.0 & 0.4 & 66.4 & 66.8 & 0.5 & 74.1 & 74. \\
\hline $\mathrm{Ni}$ & 4.2 & 0.95 & 5.2 & $\overline{2.8}$ & 1.0 & 3.9 & 2.3 & 1.0 & 3.2 & 2.5 & 1.0 & 3.5 & 3.3 & 1.0 & 4. \\
\hline $\mathrm{P}$ & 0.4 & 0.63 & 1.1 & 0.5 & 0.6 & 1.0 & 0.3 & 0.4 & 0.7 & 0.2 & 0.6 & 0.7 & 0.3 & 0.7 & - \\
\hline $\mathrm{Pb}$ & 1.7 & 0.29 & 2.0 & 1.1 & 0.3 & 1.4 & 1.0 & 0.3 & 1.2 & 0.9 & 0.3 & 1.2 & 1.3 & 0.3 & 1. \\
\hline $\mathrm{Sb}$ & 0.6 & 0.1 & 0.7 & 0.5 & 0.1 & 0.7 & 0.5 & 0.2 & 0.7 & 0.5 & 0.2 & 0.6 & 0.6 & 0.1 & 0 . \\
\hline $\mathrm{Se}$ & 23.0 & 254.9 & 277.9 & 18.1 & 268.5 & 286.6 & 14.2 & 282.2 & 296.4 & 13.7 & \begin{tabular}{|l|}
278.1 \\
\end{tabular} & 291.8 & 18.1 & 274.1 & 292. \\
\hline $\mathrm{Si}$ & 41.9 & 12.49 & 54.4 & 54.1 & 12.3 & 66.4 & 38.7 & 11.4 & 50.0 & 40.2 & 11.9 & 52.0 & $\overline{51.4}$ & 13.7 & 65. \\
\hline $\mathrm{Sr}$ & 1.1 & 21.18 & 22.3 & 0.6 & 22.2 & 22.7 & 0.4 & 19.9 & 20.3 & 0.5 & 20.2 & 20.7 & 0.6 & 22.9 & 23 \\
\hline $\mathrm{Te}$ & 9.8 & 2.59 & 12.4 & 7.0 & 2.5 & 9.6 & 6.0 & 2.7 & 8.7 & 6.7 & 3.3 & 10.0 & 8.3 & 3.3 & 11. \\
\hline $\mathrm{Ti}$ & 0.6 & $<0.1$ & 0.6 & $\overline{0.4}$ & $<0.1$ & 0.4 & 0.3 & $<0.1$ & 0.3 & 0.3 & $<0.1$ & 0.3 & $\overline{0.4}$ & $<0.1$ & 0 \\
\hline $\mathrm{Zn}$ & 2.3 & 19.46 & 21.8 & 1.7 & 19.8 & 21.5 & 1.4 & 18.4 & 19.8 & 1.5 & 18.3 & 19.8 & 1.9 & 20.4 & 22. \\
\hline $\mathrm{Zr}$ & 4.9 & 1.78 & 6.7 & 5.1 & 1.8 & 6.9 & 2.9 & 1.9 & 4.8 & 2.9 & 2.0 & 4.9 & $\overline{4.2}$ & 2.1 & 6 \\
\hline$\overline{\mathrm{Cl}}$ & $\mathrm{NA}$ & 83.7 & 83.7 & $\overline{\mathrm{NA}}$ & 87.3 & 87.3 & NA & 82.7 & 82.7 & NA & 82.2 & 82.2 & $\overline{\mathrm{NA}}$ & 88.8 & 88 \\
\hline $\mathrm{F}$ & $\mathrm{NA}$ & 68.1 & 68.1 & $\overline{\mathrm{NA}}$ & 74.9 & 74.9 & $\mathrm{NA}$ & 70.7 & 70.7 & $\mathrm{NA}$ & 71.2 & 71.2 & $\overline{\mathrm{NA}}$ & 78.0 & 78 \\
\hline I & $<0.1$ & 8.9 & 8.9 & $<0.1$ & 9.6 & 9.6 & $<0.1$ & 8.3 & 8.3 & $<0.1$ & 33.9 & 33.9 & $<0.1$ & 36.2 & 36 \\
\hline Nitrate & $\mathrm{NA}$ & 188.13 & 188.1 & $\mathrm{NA}$ & 175.51 & 175.5 & $\mathrm{NA}$ & 148.57 & 148.6 & $\mathrm{NA}$ & 167.09 & 167.1 & $\overline{\mathrm{NA}}$ & 166.25 & 166. \\
\hline Nitrite & $\mathrm{NA}$ & $<0.1$ & 0.0 & $\mathrm{NA}$ & $<0.1$ & $<0.1$ & $\mathrm{NA}$ & $<0.1$ & $<0.1$ & $\mathrm{NA}$ & $<0.1$ & $<0.1$ & $\overline{\mathrm{NA}}$ & $<0.1$ & $<0.1$ \\
\hline Sulfate & $<0.1$ & 182.63 & 182.6 & $<0.1$ & 191.95 & 192.0 & $<0.1$ & 173.31 & 173.3 & $<0.1$ & 182.63 & 182.6 & $<0.1$ & 204.99 & 205 \\
\hline
\end{tabular}


The Catholic University of America Vitreous State Laboratory
DuraMelter 1200 Start-Up Tests with AZ-101

Final Report, VSL-01R0100-2, Rev.0

Table 4.4. Analytical Results for Samples of SBS Blowdown Fluids (mg/l). (continued).

\begin{tabular}{|c|c|c|c|c|c|c|c|c|c|c|c|c|c|c|c|}
\hline & \multicolumn{3}{|c|}{$12 \mathrm{E}-\mathrm{S}-80 \mathrm{~A}$} & \multicolumn{3}{|c|}{$12 \mathrm{E}-\mathrm{S}-81 \mathrm{~A}$} & \multicolumn{3}{|c|}{$12 \mathrm{E}-\mathrm{S}-86 \mathrm{~A}$} & \multicolumn{3}{|c|}{$12 \mathrm{E}-\mathrm{S}-88 \mathrm{~A}$} & \multicolumn{3}{|c|}{$12 \mathrm{E}-\mathrm{S}-90 \mathrm{~A}$} \\
\hline Glass (kg) & \multicolumn{3}{|c|}{7050} & \multicolumn{3}{|c|}{7211} & \multicolumn{3}{|c|}{7250} & \multicolumn{3}{|c|}{7300} & \multicolumn{3}{|c|}{7500} \\
\hline $\mathrm{pH}$ & \multicolumn{3}{|c|}{2.92} & \multicolumn{3}{|c|}{2.88} & \multicolumn{3}{|c|}{2.94} & \multicolumn{3}{|c|}{2.98} & \multicolumn{3}{|c|}{2.88} \\
\hline & Sus. ${ }^{*}$ & Dis.\# & Total & Sus. & Dis. & Total & Sus. & Dis. & Total & Sus. & Dis. & Total & Sus. & Dis. & Total \\
\hline Total & 323 & 1326 & 1649 & 340 & 1406 & 1746 & 405 & 1542 & 1947 & 450 & 1614 & 2064 & 453 & 1656 & 2109 \\
\hline$\overline{\mathrm{Al}}$ & 7.8 & $\overline{34.1}$ & 41.9 & 8.1 & 35.5 & 43.6 & 10.3 & 36.8 & 47.1 & 12.4 & 39.4 & 51.8 & 11.5 & 40.9 & $\overline{52.4}$ \\
\hline As & 0.2 & 1.0 & 1.3 & 0.2 & 1.0 & 1.2 & 0.3 & 0.9 & 1.2 & 0.2 & 0.9 & 1.2 & 0.3 & 1.1 & 1.4 \\
\hline & 0.5 & 159.6 & 160.0 & 0.5 & 171.1 & 171.6 & 0.6 & 170.0 & 170.6 & 0.7 & 177.2 & 177.9 & 0.8 & 184.3 & 185.0 \\
\hline$\overline{\mathrm{Ba}}$ & 0.1 & 0.4 & 0.5 & 0.1 & 0.4 & 0.5 & 0.1 & 0.4 & 0.5 & 0.2 & 0.4 & 0.6 & 0.2 & 0.4 & 0.6 \\
\hline $\mathrm{Ca}$ & 0.1 & 6.3 & 6.4 & 0.1 & 6.1 & 6.2 & 0.2 & 6.4 & 6.6 & 0.2 & 6.6 & 6.8 & 0.2 & 6.8 & 7.0 \\
\hline$\overline{\mathrm{Cd}}$ & 0.6 & 4.2 & 4.8 & 0.7 & 4.3 & 4.9 & 0.8 & 4.6 & 5.3 & 0.8 & 4.9 & 5.7 & 0.8 & 5.1 & 6.0 \\
\hline $\mathrm{Cr}$ & 0.5 & 0.3 & 0.9 & 0.5 & 0.4 & 0.9 & 0.5 & 0.4 & 0.9 & 0.6 & 0.4 & 0.9 & 0.6 & 0.4 & 1.0 \\
\hline$\overline{\mathrm{Cs}}$ & 0.3 & 4.0 & 4.3 & 0.6 & 4.3 & 4.9 & 0.4 & 4.6 & 5.0 & 0.8 & 5.0 & 5.8 & 0.7 & 5.9 & 6. \\
\hline$\overline{\mathrm{Cu}}$ & 0.1 & 0.2 & 0.3 & 0.1 & 0.3 & 0.3 & 0.1 & 0.3 & 0.4 & 0.1 & 0.3 & 0.4 & 0.1 & 0.3 & 0.4 \\
\hline $\mathrm{Fe}$ & 68.2 & 1.7 & 69.9 & 69.1 & 1.9 & 71.1 & 78.6 & 1.9 & 80.5 & 87.7 & 1.6 & 89.3 & 83.3 & 2.1 & 85.3 \\
\hline $\mathrm{K}$ & 0.1 & 5.6 & 5.7 & 0.1 & 5.8 & 5.9 & 0.1 & 6.1 & 6.2 & 0.1 & 6.5 & 6.6 & 0.1 & 6.8 & 6.9 \\
\hline$\overline{\mathrm{Li}}$ & 0.3 & 19.4 & 19.7 & 0.4 & 19.8 & 20.2 & 0.4 & 20.9 & 21.3 & 0.5 & 22.8 & 23.3 & 0.5 & 23.7 & 24.2 \\
\hline $\mathrm{Mg}$ & 0.1 & 1.1 & 1.2 & 0.1 & 1.1 & 1.2 & 0.1 & 1.1 & 1.2 & 0.1 & 1.2 & 1.3 & 0.1 & 1.2 & 1 \\
\hline $\mathrm{Mn}$ & 1.9 & 5.7 & 7.6 & 2.1 & 5.9 & 8.0 & 2.9 & 6.5 & 9.3 & 2.9 & 6.8 & 9.7 & 2.6 & 7.1 & 9.7 \\
\hline $\mathrm{Na}$ & 0.6 & 77.7 & 78.3 & 0.6 & 79.4 & 80.0 & 0.7 & 83.4 & 84.1 & 0.9 & 91.3 & 92.2 & 0.9 & 93.3 & 94.2 \\
\hline $\mathrm{Ni}$ & 3.4 & 1.0 & 4.4 & 3.4 & 1.0 & 4.4 & 3.8 & 1.1 & 4.9 & \begin{tabular}{|l|}
4.3 \\
\end{tabular} & 1.1 & 5.4 & 4.5 & 1.1 & 5.6 \\
\hline $\mathrm{P}$ & 0.3 & 0.7 & 1.0 & 0.3 & 0.7 & 1.0 & 0.3 & 0.7 & 1.0 & 0.4 & 0.6 & 1.1 & 0.4 & 0.7 & 1.2 \\
\hline $\mathrm{Pb}$ & 1.3 & 0.3 & 1.7 & 1.4 & 0.3 & 1.7 & 1.6 & 0.4 & 1.9 & 1.7 & 0.4 & 2.1 & 1.7 & 0.4 & 2.1 \\
\hline $\mathrm{Sb}$ & 0.6 & 0.1 & 0.8 & 0.9 & 0.3 & 1.1 & 1.0 & 0.3 & 1.3 & 1.1 & 0.3 & 1.4 & 1.6 & 0.2 & 1.8 \\
\hline $\mathrm{Se}$ & 19.3 & 266.8 & 286.1 & 18.9 & 279.9 & 298.9 & 22.6 & 303.4 & 326.0 & 29.5 & 308.2 & 337.7 & 26.6 & 352.0 & 378.6 \\
\hline $\mathrm{Si}$ & 52.6 & 14.6 & 67.2 & 58.3 & 15.5 & 73.8 & 70.9 & 16.9 & 87.8 & 77.5 & 18.0 & 95.5 & 66.8 & 18.8 & 85.7 \\
\hline $\mathrm{Sr}$ & 0.6 & 21.7 & 22.3 & 0.6 & 22.5 & 23.1 & 0.7 & 24.6 & 25.3 & 0.9 & 26.7 & 27.6 & 1.0 & 27.5 & 28.5 \\
\hline $\mathrm{Te}$ & 9.0 & 4.1 & 13.1 & 9.7 & 4.4 & 14.1 & 11.6 & 4.5 & 16.1 & 13.6 & 4.1 & 17.7 & 15.2 & 4.8 & 19.9 \\
\hline $\mathrm{Ti}$ & 0.3 & $<0.1$ & 0.3 & 0.4 & $<0.1$ & 0.4 & 0.4 & $<0.1$ & 0.4 & 0.4 & $<0.1$ & 0.4 & 0.4 & $<0.1$ & 0.4 \\
\hline $\mathrm{Zn}$ & 2.0 & 21.2 & 23.1 & 2.1 & 21.5 & \begin{tabular}{|l|l|}
523.5 \\
\end{tabular} & 2.3 & 23.3 & 25.6 & 2.6 & 24.7 & 27.3 & 2.8 & 25.4 & 28.2 \\
\hline $\mathrm{Zr}$ & 4.9 & 2.4 & 7.3 & 5.3 & 2.7 & 8.0 & 7.1 & 3.2 & 10.3 & 7.6 & 3.4 & 11.0 & 6.6 & 4.5 & 11.2 \\
\hline $\mathrm{Cl}$ & $\mathrm{NA}$ & 94.0 & 94.0 & $\mathrm{NA}$ & 99.1 & 99.1 & $\mathrm{NA}$ & 101.6 & 101.6 & $\mathrm{NA}$ & 110.4 & 110.4 & $\overline{\mathrm{NA}}$ & \begin{tabular}{|l}
105.7 \\
\end{tabular} & 105.7 \\
\hline $\mathrm{F}$ & $\mathrm{NA}$ & 78.7 & 78.7 & NA & 82.3 & \begin{tabular}{|l|l|}
3 & 82.3 \\
\end{tabular} & NA & 85.0 & 85.0 & NA & 86.8 & 86.8 & $\mathrm{NA}$ & 87.8 & 87.8 \\
\hline & $<0.1$ & 35.9 & 35.9 & $<0.1$ & 35.2 & 235.2 & $<0.1$ & 34.0 & 34.0 & $<0.1$ & 29.5 & 29.5 & $<0.1$ & 32.2 & 32.2 \\
\hline Nitrate & $\mathrm{NA}$ & 163.72 & 163.7 & NA & 163.72 & 2163.7 & NA & 150.26 & 150.3 & NA & 152.78 & 152.8 & NA & 141.84 & 141.8 \\
\hline Nitrite & $\mathrm{NA}$ & $<0.1$ & $<0.1$ & $\mathrm{NA}$ & $<0.1$ & \begin{tabular}{l|l|}
1 & $<0.1$ \\
\end{tabular} & $\mathrm{NA}$ & $<0.1$ & $<0.1$ & NA & $<0.1$ & $<0.1$ & NA & $<0.1$ & $<0.1$ \\
\hline Sulfate & $<0.1$ & 218.04 & 218.0 & 1.3 & 235.74 & 4237.0 & 0.6 & 249.72 & 250.3 & 0.8 & 277.67 & 278.5 & 0.1 & \begin{tabular}{|l|}
281.4 \\
\end{tabular} & +281.2 \\
\hline
\end{tabular}


The Catholic University of America Vitreous State Laboratory
DuraMelter 1200 Start-Up Tests with AZ-101

Final Report, VSL-01R0100-2, Rev.0

Table 4.4. Analytical Results for Samples of SBS Blowdown Fluids (mg/l). (continued).

\begin{tabular}{|c|c|c|c|c|c|c|c|c|c|c|c|c|c|c|c|}
\hline & \multicolumn{3}{|c|}{$12 \mathrm{E}-\mathrm{S}-95 \mathrm{~A}$} & \multicolumn{3}{|c|}{$12 \mathrm{E}-\mathrm{S}-97 \mathrm{~A}$} & \multicolumn{3}{|c|}{$12 \mathrm{E}-\mathrm{S}-98 \mathrm{~A}$} & \multicolumn{3}{|c|}{$12 \mathrm{E}-\mathrm{S}-98 \mathrm{~B}$} & \multicolumn{3}{|c|}{$12 \mathrm{E}-\mathrm{S}-99 \mathrm{~A}$} \\
\hline Glass (kg) & \multicolumn{3}{|c|}{7733} & \multicolumn{3}{|c|}{7800} & \multicolumn{3}{|c|}{7850} & \multicolumn{3}{|c|}{7900} & \multicolumn{3}{|c|}{7950} \\
\hline $\mathrm{pH}$ & \multicolumn{3}{|c|}{2.87} & \multicolumn{3}{|c|}{2.89} & \multicolumn{3}{|c|}{2.87} & \multicolumn{3}{|c|}{2.83} & \multicolumn{3}{|c|}{2.86} \\
\hline & Sus. ${ }^{\text {. }}$ & Dis.\# & Total & Sus. & Dis. & Total & Sus. & Dis. & Total & Sus. & Dis. & Total & Sus. & Dis. & Total \\
\hline Total & 458 & 1766 & 2224 & 499 & 1905 & 2404 & 488 & 1888 & 2376 & 470 & 1896 & 2366 & 482 & 812 & 1294 \\
\hline $\mathrm{Al}$ & 11.7 & 41.8 & 53.5 & 12.7 & 42.6 & 55.3 & 12.3 & 42.8 & 55.1 & 11.2 & 43.2 & 54.4 & 12.1 & 43.3 & 55.4 \\
\hline As & 0.3 & 1.0 & 1.3 & 0.3 & 1.0 & 1.3 & 0.3 & 0.9 & 1.2 & 0.4 & 1.1 & 1.5 & 0.3 & 1.0 & 1.4 \\
\hline B & 0.8 & 194.9 & 195.7 & 0.9 & 197.4 & 198.3 & 0.8 & 198.7 & 199.5 & 0.8 & 199.5 & 200.3 & 0.8 & 204.9 & 205.7 \\
\hline $\mathrm{Ba}$ & 0.2 & 0.4 & 0.6 & 0.2 & 0.4 & 0.6 & 0.2 & 0.4 & 0.6 & 0.2 & 0.3 & 0.6 & 0.2 & 0.4 & 0.6 \\
\hline $\mathrm{Ca}$ & 0.2 & 7.0 & 7.2 & 0.2 & 7.4 & 7.5 & 0.2 & 7.2 & 7.4 & 0.2 & 7.3 & 7.5 & 0.2 & 7.2 & 7.4 \\
\hline $\mathrm{Cd}$ & 0.9 & 5.4 & 6.3 & 1.0 & 5.4 & 6.4 & 1.0 & 5.5 & 6.5 & 0.9 & 5.5 & 6.4 & 0.9 & 5.6 & 6.5 \\
\hline $\mathrm{Cr}$ & 0.6 & 0.4 & 1.0 & 0.6 & 0.4 & 1.0 & 0.7 & 0.4 & 1.0 & 0.6 & 0.4 & 1.0 & 0.6 & 0.4 & 1.0 \\
\hline Cs & 0.7 & 6.4 & 7.1 & 0.8 & 6.5 & 7.3 & 0.8 & 6.6 & 7.4 & 0.7 & 6.8 & 7.5 & 0.7 & 7.3 & 8.0 \\
\hline $\mathrm{Cu}$ & 0.1 & 0.3 & 0.4 & 0.1 & 0.3 & 0.4 & 0.1 & 0.3 & 0.4 & 0.1 & 0.3 & 0.4 & 0.1 & 0.4 & 0.4 \\
\hline $\mathrm{Fe}$ & 88.7 & 1.8 & 90.5 & 98.4 & 1.8 & 100.2 & 96.7 & 2.0 & 98.6 & 92.5 & 1.9 & 94.4 & 95.0 & 2.2 & 97.2 \\
\hline $\mathrm{K}$ & 0.1 & 7.0 & 7.1 & 0.1 & 7.2 & 7.3 & 0.1 & 7.3 & 7.4 & 0.1 & 7.3 & 7.4 & 0.1 & 7.5 & 7.6 \\
\hline $\mathrm{Li}$ & 0.5 & 25.1 & 25.6 & 0.6 & 25.8 & 26.3 & 0.5 & 26.9 & 27.4 & 0.5 & 26.3 & 26.8 & 0.5 & 26.6 & 27.1 \\
\hline $\mathrm{Mg}$ & 0.1 & 1.2 & 1.3 & 0.1 & 1.3 & 1.4 & 0.1 & 1.3 & 1.4 & 0.1 & 1.3 & 1.4 & 0.1 & 1.3 & 1.4 \\
\hline $\mathrm{Mn}$ & 2.8 & 7.3 & 10.1 & 2.9 & 7.5 & 10.4 & 2.8 & 7.5 & 10.4 & 2.8 & 7.4 & 10.3 & 2.9 & 7.6 & 10.5 \\
\hline $\mathrm{Na}$ & 0.9 & 100.1 & 101.0 & 1.0 & 98.9 & 99.9 & 1.0 & 101.2 & 102.2 & 1.0 & 100.1 & 101.0 & 1.0 & 101.6 & 102.6 \\
\hline $\mathrm{Ni}$ & 4.4 & 1.2 & 5.6 & 4.9 & 1.2 & 6.1 & 4.8 & 1.2 & 6.0 & 4.6 & 1.2 & 5.8 & 4.7 & 1.3 & 6.0 \\
\hline $\mathrm{P}$ & 0.5 & 0.9 & 1.3 & 0.4 & 0.8 & 1.2 & 0.4 & 0.8 & 1.2 & 0.5 & 0.8 & 1.2 & 0.4 & 0.8 & 1.2 \\
\hline $\mathrm{Pb}$ & 1.7 & 0.4 & 2.1 & 2.0 & 0.4 & 2.4 & 2.0 & 0.5 & 2.4 & 1.9 & 0.5 & 2.4 & 2.0 & 0.5 & 2.4 \\
\hline $\mathrm{Sb}$ & 1.1 & 0.2 & 1.3 & 1.2 & 0.2 & 1.4 & 1.3 & 0.1 & 1.4 & 1.3 & 0.2 & 1.4 & 1.3 & 0.2 & 1.5 \\
\hline $\mathrm{Se}$ & 27.6 & 335.9 & 363.5 & 31.1 & 305.9 & 336.9 & 30.6 & 333.0 & 363.5 & 32.2 & 341.7 & 373.9 & 30.3 & 322.2 & 352.5 \\
\hline $\mathrm{Si}$ & 75.7 & 19.7 & 95.4 & 83.6 & 19.1 & 102.7 & 75.4 & 19.8 & 95.2 & 78.9 & 19.7 & 98.6 & 79.2 & 19.7 & 98.9 \\
\hline $\mathrm{Sr}$ & 1.0 & 28.2 & 29.2 & 1.1 & 28.8 & 29.9 & 1.1 & 29.1 & 30.2 & 1.1 & 29.1 & 30.2 & 1.1 & 29.6 & 30.8 \\
\hline $\mathrm{Te}$ & 14.4 & 4.6 & 19.1 & 16.6 & 4.7 & 21.3 & 16.7 & 5.0 & 21.7 & 16.4 & 4.6 & 21.0 & 16.9 & 5.2 & 22.2 \\
\hline Ti & 0.4 & $<0.1$ & 0.4 & 0.4 & $<0.1$ & 0.4 & 0.4 & $<0.1$ & 0.4 & 0.4 & $<0.1$ & 0.4 & 0.4 & $<0.1$ & 0.4 \\
\hline $\mathrm{Zn}$ & 2.7 & 26.4 & 29.1 & 3.0 & 27.8 & 30.9 & 3.0 & 27.6 & 30.6 & 2.8 & 27.2 & 30.1 & 2.9 & 27.5 & 30.4 \\
\hline $\mathrm{Zr}$ & 7.1 & 4.9 & 12.1 & 7.2 & 5.2 & 12.4 & 6.9 & 5.3 & 12.2 & 6.8 & 5.5 & 12.2 & 6.9 & 5.6 & 12.5 \\
\hline $\mathrm{Cl}$ & NA & 90.3 & 90.3 & NA & 96.8 & 96.8 & NA & 92.9 & 92.9 & NA & 89.6 & 89.6 & NA & 98.1 & 98.1 \\
\hline $\mathrm{F}$ & NA & 120.1 & 120.1 & $\mathrm{NA}$ & 122.2 & 122.2 & $\mathrm{NA}$ & 121.5 & 121.5 & $\mathrm{NA}$ & 112.4 & 112.4 & $\mathrm{NA}$ & 134.8 & 134.8 \\
\hline & $<0.1$ & 29.8 & 29.8 & $<0.1$ & 31.5 & 31.5 & $<0.1$ & 35.2 & 35.2 & $<0.1$ & 32.7 & 32.7 & $<0.1$ & 31.5 & 31.5 \\
\hline Nitrate & $\mathrm{NA}$ & 159.61 & 159.6 & NA & 154.9 & 154.9 & NA & 147.85 & 147.9 & NA & 143.15 & 143.2 & NA & 152.55 & 152.6 \\
\hline Nitrite & $\mathrm{NA}$ & $<0.1$ & $<0.1$ & $\mathrm{NA}$ & $<0.1$ & $<0.1$ & $\mathrm{NA}$ & $<0.1$ & $<0.1$ & $\mathrm{NA}$ & $<0.1$ & $<0.1$ & NA & $<0.1$ & $<0.1$ \\
\hline Sulfate & 0.9 & \begin{tabular}{|l|}
323.97 \\
\end{tabular} & 324.9 & 2.3 & 341.33 & 343.6 & 1.2 & 330.17 & 331.4 & 1.3 & 311.56 & 312.9 & 1.3 & 354.98 & 356.3 \\
\hline
\end{tabular}


The Catholic University of America Vitreous State Laboratory
DuraMelter 1200 Start-Up Tests with AZ-101

Final Report, VSL-01R0100-2, Rev.0

Table 4.4. Analytical Results for Samples of SBS Blowdown Fluids (mg/l). (continued).

\begin{tabular}{|c|c|c|c|c|c|c|c|c|c|c|c|c|c|c|c|}
\hline & \multicolumn{3}{|c|}{$12 \mathrm{E}-\mathrm{S}-105 \mathrm{~A}$} & \multicolumn{3}{|c|}{$12 \mathrm{E}-\mathrm{S}-105 \mathrm{~B}$} & \multicolumn{3}{|c|}{$12 \mathrm{E}-\mathrm{S}-109 \mathrm{~A}$} & \multicolumn{3}{|c|}{ 12E-S-109B } & \multicolumn{3}{|c|}{$12 \mathrm{E}-\mathrm{S}-110 \mathrm{~A}$} \\
\hline Glass (kg) & \multicolumn{3}{|c|}{8200} & \multicolumn{3}{|c|}{8250} & \multicolumn{3}{|c|}{8400} & \multicolumn{3}{|c|}{8400} & \multicolumn{3}{|c|}{8550} \\
\hline $\mathrm{pH}$ & \multicolumn{3}{|c|}{2.86} & \multicolumn{3}{|c|}{2.82} & \multicolumn{3}{|c|}{2.86} & \multicolumn{3}{|c|}{2.83} & \multicolumn{3}{|c|}{2.84} \\
\hline & Sus. * & Dis.\# & Total & Sus. & Dis. & Total & Sus. & \begin{tabular}{|l} 
Dis. \\
\end{tabular} & Total & Sus. & Dis. & Total & Sus. & Dis. & Total \\
\hline Total & 498 & 1556 & 2054 & 497 & 1676 & 2173 & 518 & 1786 & 2304 & 512 & 1572 & 2084 & 507 & 1380 & 1887 \\
\hline $\mathrm{Al}$ & 11.8 & 44.31 & 56.1 & 11.6 & 45 & 56.6 & 12.6 & 45.95 & 58.5 & 13.1 & 45.3 & 58.4 & 12.3 & 46.5 & 58.8 \\
\hline As & 0.4 & 1.14 & 1.5 & 0.3 & 1.1 & 1.4 & 0.5 & 1.06 & 1.6 & 0.4 & 1.1 & 1.5 & 0.3 & 1.1 & 1.4 \\
\hline $\bar{B}$ & 0.9 & 211.74 & 212.6 & 0.9 & 214.94 & 215.8 & 0.9 & 216.87 & 217.8 & 0.9 & 216.6 & 217.6 & 0.9 & 212.2 & 213. \\
\hline $\mathrm{Ba}$ & 0.3 & 0.3 & 0.6 & 0.3 & 0.3 & 0.6 & 0.3 & 0.3 & 0.6 & 0.3 & 0.3 & 0.6 & 0.3 & 0.3 & 0.6 \\
\hline $\mathrm{Ca}$ & 0.2 & 7.3 & 7.4 & 0.2 & 6.9 & 7.1 & 0.2 & 7.1 & 7.3 & 0.2 & 7.7 & 7.9 & 0.2 & 7.0 & 7.1] \\
\hline $\mathrm{Cd}$ & 0.9 & 5.6 & 6.5 & 0.9 & 5.7 & 6.6 & 1.0 & 5.7 & 6.7 & 0.9 & 5.9 & 6.8 & 1.0 & 5.9 & 6.9 \\
\hline $\mathrm{Cr}$ & 0.6 & 0.4 & 1.0 & 0.6 & 0.4 & 1.0 & 0.6 & 0.4 & 1.0 & 0.6 & 0.4 & 1.0 & 0.6 & 0.4 & 1. \\
\hline $\mathrm{Cs}$ & 0.8 & 7.6 & 8.4 & 0.6 & 7.2 & 7.8 & 0.6 & 7.7 & 8.3 & 0.5 & 8.2 & 8.7 & 0.9 & 7.1 & 8.1 \\
\hline $\mathrm{Cu}$ & 0.1 & 0.4 & 0.4 & 0.1 & 0.4 & 0.5 & 0.1 & 0.4 & 0.5 & 0.1 & 0.4 & 0.5 & 0.1 & 0.4 & 0. \\
\hline$\overline{\mathrm{Fe}}$ & 96.6 & 2.1 & 98.7 & 95.3 & 2.3 & 97.6 & \begin{tabular}{|l|}
104.3 \\
\end{tabular} & 2.4 & 106.7 & 102.3 & 2.6 & 104.9 & 104.7 & 2.7 & 107.4 \\
\hline $\bar{K}$ & 0.1 & 7.4 & 7.5 & 0.1 & 7.4 & 7.5 & 0.1 & 7.6 & 7.7 & 0.1 & 7.6 & 7.7 & 0.1 & 7.6 & 7.7 \\
\hline $\mathrm{Li}$ & 0.5 & 26.4 & 27.0 & 0.5 & 26.5 & 27.1 & 0.6 & 27.2 & 27.8 & 0.6 & 26.9 & 27.4 & 0.5 & 27.0 & 27.5 \\
\hline $\mathrm{Mg}$ & 0.1 & 1.3 & 1.4 & 0.11 & 1.2 & 1.3 & 0.1 & 1.2 & 1.3 & 0.1 & 1.4 & 1.5 & 0.1 & 1.2 & $1 .$. \\
\hline $\mathrm{Mn}$ & 3.1 & 7.8 & 10.9 & 3.0 & 7.9 & 10.9 & 3.0 & 7.1 & 10.1 & 3.2 & 7.0 & 10.3 & 2.9 & 7.1 & 10.0 \\
\hline $\mathrm{Na}$ & 1.1 & 104.7 & 105.8 & 1.1 & 106.8 & 107.9 & 1.1 & 107.6 & 108.7 & 1.1 & 107.1 & 108.2 & 1.0 & 105.1 & 106.1 \\
\hline $\mathrm{Ni}$ & 4.9 & 1.3 & 6.1 & 4.9 & 1.3 & 6.2 & 5.2 & 1.3 & 6.5 & 5.3 & 1.3 & 6.6 & 4.9 & 1.3 & $\overline{6.2}$ \\
\hline $\mathrm{P}$ & 0.5 & 0.7 & 1.2 & 0.5 & 0.9 & 1.3 & 0.5 & 0.8 & 1.3 & 0.5 & 1.1 & 1.6 & 0.5 & 0.9 & 1. \\
\hline$\overline{\mathrm{Pb}}$ & 1.9 & 0.5 & 2.4 & 1.9 & 0.5 & 2.4 & 2.1 & 0.5 & 2.5 & 2.1 & 0.5 & 2.6 & 2.1 & 0.5 & 2.6 \\
\hline $\mathrm{Sb}$ & 1.2 & 0.2 & 1.4 & 1.2 & 0.3 & 1.5 & 1.2 & 0.3 & 1.5 & 1.3 & 0.2 & 1.5 & 1.3 & 0.2 & 1. \\
\hline $\mathrm{Se}$ & 30.6 & 354.2 & 384.8 & 32.0 & 342.4 & 374.4 & 33.3 & 348.6 & 381.9 & 33.5 & 343.2 & 376.7 & 32.9 & 364.3 & 397. \\
\hline$\overline{\mathrm{Si}}$ & 83.2 & 19.7 & \begin{tabular}{|l|}
102.9 \\
\end{tabular} & 82.9 & 20.1 & \begin{tabular}{|l|}
103.1 \\
\end{tabular} & 63.6 & 20.4 & 84.0 & 85.5 & 20.2 & \begin{tabular}{|l|}
105.8 \\
\end{tabular} & 84.3 & 20.5 & 104.8 \\
\hline $\mathrm{Sr}$ & 1.3 & 30.0 & 31.2 & 1.3 & 30.3 & 31.6 & 1.4 & 31.3 & 32.7 & 1.4 & 30.8 & 32.3 & 1.4 & 30.8 & $\overline{32.2}$ \\
\hline $\mathrm{Te}$ & 16.8 & 5.8 & 22.6 & 16.8 & 6.0 & 22.8 & 17.3 & 6.1 & 23.4 & 17.3 & 6.1 & 23.3 & 18.2 & 7.6 & 25.9 \\
\hline Ti & 0.5 & $<0.1$ & 0.5 & 0.4 & $<0.1$ & 0.4 & 0.4 & $<0.1$ & 0.4 & 0.4 & $<0.1$ & 0.4 & 0.4 & $<0.1$ & 0. \\
\hline $\mathrm{Zn}$ & 3.0 & 27.4 & 30.3 & 3.0 & 28.4 & 31.3 & 3.2 & 28.6 & 31.8 & 3.1 & 28.5 & 31.6 & 3.1 & 28.4 & 31. \\
\hline $\mathrm{Zr}$ & 7.2 & 5.8 & 13.1 & 7.0 & 6.1 & 13.1 & 7.0 & 6.2 & 13.2 & 7.2 & 6.4 & 13.6 & 6.6 & 6.5 & $\overline{13.1}$ \\
\hline $\mathrm{Cl}$ & NA & 94.8 & 94.8 & NA & 100.71 & 100.7 & NA & 100.06 & 100.1 & $\mathrm{NA}$ & 103.33 & 103.3 & $\mathrm{NA}$ & 103.98 & 104.0 \\
\hline $\mathrm{F}$ & $\mathrm{NA}$ & 132.0 & 132.0 & $\mathrm{NA}$ & 130.6 & 130.6 & $\mathrm{NA}$ & 134.8 & 134.8 & NA & 140.39 & 140.4 & $\mathrm{NA}$ & 136.2 & 136.2 \\
\hline & $<0.1$ & 30.6 & 30.6 & $<0.1$ & 33.2 & 33.2 & $<0.1$ & 22.9 & 22.9 & $<0.1$ & 21.7 & 21.7 & $<0.1$ & 21.6 & 21. \\
\hline Nitrate & $\mathrm{NA}$ & 138.45 & 138.5 & $\mathrm{NA}$ & 143.15 & 143.2 & $\mathrm{NA}$ & 143.15 & 143.2 & $\mathrm{NA}$ & 150.2 & 150.2 & $\mathrm{NA}$ & 147.85 & 147. \\
\hline Nitrite & $\mathrm{NA}$ & $<0.1$ & $<0.1$ & NA & $<0.1$ & $<0.1$ & $\mathrm{NA}$ & $<0.1$ & $<0.1$ & NA & $<0.1$ & $<0.1$ & NA & $<0.1$ & $<0$. \\
\hline Sulfate & & 348.77 & 349.8 & & 371.1 & $\mid 372.1$ & 0.5 & 376.06 & 3 & 0.8 & 385.98 & 386.8 & & 393.43 & 398. \\
\hline
\end{tabular}


The Catholic University of America Vitreous State Laboratory
DuraMelter 1200 Start-Up Tests with AZ-101

Final Report, VSL-01R0100-2, Rev.0

Table 4.4. Analytical Results for Samples of SBS Blowdown Fluids (mg/l). (continued).

\begin{tabular}{|c|c|c|c|c|c|c|c|c|c|}
\hline & \multicolumn{3}{|c|}{$12 \mathrm{E}-\mathrm{S}-118 \mathrm{~A}$} & \multicolumn{3}{|c|}{$12 \mathrm{E}-\mathrm{S}-130 \mathrm{~A}$} & \multicolumn{3}{|c|}{ 12E-S-130C } \\
\hline$\overline{\text { Glass }(\mathrm{kg})}$ & \multicolumn{3}{|c|}{8650} & \multicolumn{3}{|c|}{8650} & \multicolumn{3}{|c|}{8650} \\
\hline $\mathrm{pH}$ & \multicolumn{3}{|c|}{2.59} & \multicolumn{3}{|c|}{2.74} & \multicolumn{3}{|c|}{2.77} \\
\hline & Sus. * & Dis.\# & Total & Sus. & Dis. & Total & Sus. & Dis. & Total \\
\hline Total & 690 & 2270 & 2960 & 402 & 2062 & 2464 & 370 & 1484 & 1854 \\
\hline $\mathrm{Al}$ & 16.7 & 50.0 & 66.7 & 10.6 & 51.6 & 62.2 & 10.5 & 37.3 & 47.8 \\
\hline As & 0.6 & 1.1 & 1.7 & 0.2 & 1.2 & 1.4 & 0.3 & 0.9 & \begin{tabular}{|l|l|}
9 & 1.1 \\
\end{tabular} \\
\hline $\mathrm{B}$ & 1.2 & 217.4 & 218.6 & 0.8 & 222.6 & 223.4 & 0.7 & 168.3 & 169.0 \\
\hline $\mathrm{Ba}$ & 0.4 & 0.3 & 0.6 & 0.2 & 0.2 & 0.5 & 0.2 & 0.2 & 0.4 \\
\hline $\mathrm{Ca}$ & 0.2 & 7.5 & 7.7 & 0.2 & 8.7 & 8.9 & 0.2 & 15.9 & 16.1 \\
\hline $\mathrm{Cd}$ & 1.1 & 6.2 & 7.3 & 0.7 & 6.4 & 7.1 & 0.7 & 4.7 & 5.4 \\
\hline $\mathrm{Cr}$ & 0.7 & 0.4 & 1.1 & 0.5 & 0.4 & 0.8 & 0.4 & 0.3 & 0.7 \\
\hline $\mathrm{Cs}$ & 0.9 & 7.7 & 8.6 & 0.7 & 8.1 & 8.8 & 0.4 & 6.2 & 6.6 \\
\hline $\mathrm{Cu}$ & 0.1 & 0.4 & 0.5 & 0.1 & 0.4 & 0.5 & 0.1 & 0.3 & 0.4 \\
\hline$\overline{\mathrm{Fe}}$ & 18.9 & 2.1 & 121.0 & 74.7 & 2.4 & 77.0 & 68.7 & 1.9 & 70.6 \\
\hline $\mathrm{K}$ & 0.2 & 7.9 & 8.1 & 0.1 & 8.4 & 8.5 & 0.1 & 6.7 & 6.8 \\
\hline $\mathrm{Li}$ & 0.7 & 28.8 & 29.4 & 0.4 & 28.0 & 28.5 & 0.4 & 21.8 & 22.2 \\
\hline $\mathrm{Mg}$ & 0.1 & 1.3 & 1.4 & 0.1 & 1.5 & 1.6 & 0.1 & 4.0 & 4.1 \\
\hline $\mathrm{Mn}$ & 6.2 & 8.0 & 14.2 & 2.4 & 8.9 & 11.3 & 2.2 & 7.2 & 9.4 \\
\hline $\mathrm{Na}$ & 1.4 & 112.1 & 113.5 & 0.9 & 122.4 & 4123.3 & 0.8 & 89.9 & 90.7 \\
\hline $\mathrm{Ni}$ & 6.1 & 1.4 & 7.5 & 3.9 & 1.7 & 5.6 & 3.6 & 1.2 & 4.8 \\
\hline$P$ & 0.7 & 1.0 & 1.7 & 0.4 & 1.0 & 1.4 & 0.4 & 0.6 & 1.0 \\
\hline$\overline{\mathrm{Pb}}$ & 2.6 & 0.5 & 3.0 & 1.5 & 0.5 & 2.0 & 1.4 & 0.4 & 1.8 \\
\hline $\mathrm{Sb}$ & 2.0 & 0.2 & 2.2 & 1.3 & 0.2 & 1.5 & 0.9 & 0.2 & 1.1 \\
\hline $\mathrm{Se}$ & 40.8 & 404.1 & 444.9 & 25.9 & 426.1 & 1452.0 & 24.0 & 302.1 & 326.1 \\
\hline $\mathrm{Si}$ & 124.1 & 21.6 & 145.7 & 61.7 & 22.5 & 584.2 & 60.0 & 17.2 & 77.2 \\
\hline $\mathrm{Sr}$ & 1.8 & 32.2 & 34.1 & 1.3 & 34.6 & 35.9 & 1.1 & 25.0 & 26.1 \\
\hline $\mathrm{Te}$ & 21.5 & 5.9 & 27.4 & 13.9 & 6.3 & 20.2 & 12.1 & 4.9 & 17.1 \\
\hline $\mathrm{Ti}$ & 0.5 & $<0.1$ & 0.5 & 0.4 & $<0.1$ & 0.4 & 0.3 & $<0.1$ & 0.3 \\
\hline $\mathrm{Zn}$ & 3.8 & 30.1 & 33.9 & 2.5 & 32.6 & 35.1 & 2.3 & 24.3 & 26.6 \\
\hline $\mathrm{Zr}$ & 16.1 & 6.5 & 22.6 & 5.1 & 7.0 & 12.1 & 4.9 & 5.0 & 9.9 \\
\hline $\mathrm{Cl}$ & $\mathrm{NA}$ & 107.9 & 107.9 & $\mathrm{NA}$ & 114.44 & 4114.4 & NA & 89.59 & 89.6 \\
\hline $\mathrm{F}$ & $\mathrm{NA}$ & 144.59 & 144.6 & $\mathrm{NA}$ & 147.39 & 147.4 & NA & 116.61 & 116.6 \\
\hline & $<0.1$ & 21.1 & \begin{tabular}{|l|}
21.1 \\
\end{tabular} & $<0.1$ & 15.3 & \begin{tabular}{|l|l|}
3 & 15.3 \\
\end{tabular} & $<0.1$ & 12.2 & 12.2 \\
\hline Nitrate & $\mathrm{NA}$ & 138.45 & 138.5 & NA & 131.39 & 131.4 & NA & 96.37 & 96.4 \\
\hline Nitrite & $\mathrm{NA}$ & $<0.1$ & $<0.1$ & NA & $<0.1$ & $<0.1$ & $\mathrm{NA}$ & $<0.1$ & $<0.1$ \\
\hline Sulfate & 1.1 & 426.13 & 427.2 & 2.3 & 433.88 & 8436.2 & 0.7 & 323.97 & 324.7 \\
\hline
\end{tabular}


The Catholic University of America Vitreous State Laboratory
DuraMelter 1200 Start-Up Tests with AZ-101

Final Report, VSL-01R0100-2, Rev.0

Table 4.4. Analytical Results for Samples of SBS Blowdown Fluids (mg/l). (continued).

\begin{tabular}{|c|c|c|c|c|c|c|c|c|c|c|c|c|c|c|c|}
\hline & \multicolumn{3}{|c|}{$12 \mathrm{E}-\mathrm{S}-137 \mathrm{~A}$} & \multicolumn{3}{|c|}{ 12E-S-137B } & \multicolumn{3}{|c|}{$12 \mathrm{E}-\mathrm{S}-137 \mathrm{C}$} & \multicolumn{3}{|c|}{$12 \mathrm{E}-\mathrm{S}-138 \mathrm{~A}$} & \multicolumn{3}{|c|}{$12 \mathrm{E}-\mathrm{S}-138 \mathrm{~B}$} \\
\hline Glass (kg) & \multicolumn{3}{|c|}{8700} & \multicolumn{3}{|c|}{8700} & \multicolumn{3}{|c|}{8700} & \multicolumn{3}{|c|}{8750} & \multicolumn{3}{|c|}{8750} \\
\hline $\mathrm{pH}$ & \multicolumn{3}{|c|}{2.79} & \multicolumn{3}{|c|}{2.82} & \multicolumn{3}{|c|}{2.82} & \multicolumn{3}{|c|}{3.01} & \multicolumn{3}{|c|}{3.09} \\
\hline & Sus. * & Dis.\# & Total & Sus. & \begin{tabular}{|l} 
Dis. \\
\end{tabular} & Total & Sus. & Dis. & Total & Sus. & \begin{tabular}{|l} 
Dis. \\
\end{tabular} & Total & Sus. & Dis. & Total \\
\hline Total & 346 & 1560 & 1906 & 350 & 1416 & 1766 & 365 & 1292 & 1657 & 412 & 1340 & 1752 & 390 & 1480 & 1870 \\
\hline$\overline{\mathrm{Al}}$ & 5.6 & 35.8 & 41.4 & 5.5 & 40.6 & 46.2 & 5.7 & 38.8 & 44.6 & 8.2 & 39.8 & 48.0 & 8.7 & 39.8 & 48.5 \\
\hline As & $\overline{0.1}$ & 1.0 & 1.1 & 0.2 & 1.1 & 1.3 & 0.2 & 1.0 & 1.2 & 0.3 & 0.9 & 1.2 & 0.3 & 0.8 & 1.1 \\
\hline$B$ & 0.3 & 165.7 & 166.0 & 0.5 & 163.8 & 164.3 & 1.0 & 153.9 & 155.0 & 0.7 & 159.8 & 160.5 & 0.6 & 172.5 & 173.1 \\
\hline $\mathrm{Ba}$ & 0.1 & 0.2 & 0.3 & 0.2 & 0.2 & 0.4 & 0.2 & 0.2 & 0.4 & 0.2 & 0.2 & 0.4 & 0.2 & 0.2 & 0.4 \\
\hline $\mathrm{Ca}$ & 0.1 & 15.6 & 15.7 & 0.1 & 14.6 & 14.8 & 0.1 & 13.7 & 13.9 & 0.2 & 12.5 & 12.7 & 0.2 & 12.3 & 12.5 \\
\hline$\overline{\mathrm{Cd}}$ & 0.4 & 4.6 & 4.9 & 0.7 & 4.3 & 5.0 & 0.7 & 4.0 & 4.7 & 0.8 & 4.3 & 5.1 & 0.8 & 4.5 & 5.2 \\
\hline $\mathrm{Cr}$ & 0.2 & $\overline{0.3}$ & 0.5 & 0.4 & 0.3 & 0.7 & 0.4 & 0.3 & 0.7 & 0.5 & $\begin{array}{l}0.3 \\
\end{array}$ & 0.7 & 0.4 & 0.3 & 0.7 \\
\hline $\mathrm{Cs}$ & 0.2 & $\overline{6.6}$ & 6.8 & 0.5 & 5.1 & 5.6 & 0.4 & $\overline{5.3}$ & 5.7 & 0.7 & 4.8 & 5.5 & $<0.1$ & 4.9 & 4.9 \\
\hline $\mathrm{Cu}$ & 0.0 & $\overline{0.3}$ & 0.3 & 0.1 & 0.3 & 0.4 & 0.1 & 0.3 & 0.3 & 0.1 & 0.3 & 0.4 & 0.1 & 0.3 & 0.4 \\
\hline $\mathrm{Fe}$ & 40.9 & 1.8 & 42.8 & 70.9 & 0.9 & 71.8 & 73.4 & 0.8 & 74.2 & 78.5 & 0.5 & 79.0 & 72.2 & 0.4 & 72.6 \\
\hline $\bar{K}$ & 0.0 & 6.4 & 6.5 & 0.1 & 5.7 & 5.8 & 0.5 & $\overline{5.1}$ & 5.6 & 0.1 & 5.2 & 5.3 & 0.1 & 5.4 & 5.5 \\
\hline$\overline{\mathrm{Li}}$ & 0.2 & 20.8 & 21.0 & 0.3 & 19.6 & 19.9 & 0.3 & 18.2 & 18.5 & 0.4 & 18.9 & 19.3 & 0.4 & 20.0 & 20.5 \\
\hline$\overline{\mathrm{Mg}}$ & 0.0 & 3.9 & 4.0 & 0.1 & 3.8 & 3.9 & 0.1 & 3.6 & 3.7 & 0.1 & 3.4 & 3.5 & 0.1 & 3.3 & 3.4 \\
\hline $\mathrm{Mn}$ & 1.3 & 7.0 & 8.3 & 2.3 & 6.2 & 8.5 & 2.5 & 6.0 & 8.4 & 2.9 & 5.8 & 8.7 & 3.1 & 6.2 & 9.3 \\
\hline $\mathrm{Na}$ & 0.4 & 86.6 & 87.0 & 0.6 & 92.6 & 93.2 & 0.6 & 86.5 & 87.1 & 0.7 & 90.3 & 91.0 & 0.8 & 97.6 & 98.3 \\
\hline$\widehat{N i}$ & 2.1 & 1.2 & 3.3 & 3.5 & 1.2 & 4.7 & 3.6 & 1.1 & 4.7 & 3.9 & 1.1 & 5.0 & 3.6 & 1.1 & 4.8 \\
\hline $\mathrm{P}$ & 0.2 & 0.7 & 0.9 & 0.4 & 0.6 & 1.0 & 0.3 & 0.5 & 0.8 & 0.5 & 0.7 & 1.1 & 0.4 & 0.7 & 1.1 \\
\hline $\mathrm{Pb}$ & 0.8 & 0.4 & 1.1 & 1.5 & 0.3 & 1.8 & 1.5 & 0.3 & 1.8 & 1.7 & 0.3 & 2.0 & 1.5 & 0.3 & 1.8 \\
\hline $\mathrm{Sb}$ & 0.5 & 0.1 & 0.6 & 0.9 & 0.2 & 1.1 & 1.0 & 0.2 & 1.2 & 1.1 & 0.2 & 1.3 & 1.0 & 0.2 & 1.2 \\
\hline $\mathrm{Se}$ & 9.3 & 304.4 & 313.7 & 24.4 & 317.7 & 342.1 & 25.2 & 285.8 & 311.1 & 26.8 & 289.7 & 316.5 & 24.2 & 262.8 & 287.0 \\
\hline $\mathrm{Si}$ & 36.8 & 16.6 & 53.4 & 61.0 & 16.3 & 77.3 & 65.1 & 15.5 & 80.6 & 73.2 & 16.4 & 89.6 & 71.0 & 18.5 & 89.6 \\
\hline $\mathrm{Sr}$ & 0.6 & 23.6 & 24.2 & 1.0 & 23.7 & 24.7 & 1.0 & 23.3 & 24.2 & 1.0 & 23.6 & 24.6 & 0.9 & 24.3 & 25.2 \\
\hline $\mathrm{Te}$ & 6.4 & 5.0 & 11.4 & 12.9 & 4.1 & 17.0 & 13.5 & 3.6 & 17.1 & 14.1 & 2.9 & 17.0 & 13.5 & 2.7 & 16.2 \\
\hline $\mathrm{Ti}$ & 0.2 & $<0.1$ & 0.2 & 0.3 & $<0.1$ & 0.3 & 0.3 & $<0.1$ & 0.3 & 0.3 & $<0.1$ & 0.3 & 0.3 & $<0.1$ & 0.3 \\
\hline $\mathrm{Zn}$ & 1.3 & 22.7 & 24.0 & 2.1 & 21.9 & 24.0 & 2.2 & 21.0 & 23.2 & 2.5 & 22.0 & 24.5 & 2.4 & 22.7 & 25.1 \\
\hline $\mathrm{Zr}$ & 2.7 & 4.9 & 7.5 & 5.7 & 3.9 & 9.6 & 6.3 & 3.6 & 9.9 & 8.3 & 3.0 & 11.3 & 9.0 & 2.7 & 11.6 \\
\hline $\mathrm{Cl}$ & $\mathrm{NA}$ & 88.29 & 88.3 & $\mathrm{NA}$ & 80.4 & 80.4 & $\mathrm{NA}$ & 87.0 & 87.0 & $\mathrm{NA}$ & 74.7 & 74.7 & NA & 74.7 & 74.7 \\
\hline $\mathrm{F}$ & $\overline{\mathrm{NA}}$ & 115.21 & 115.2 & $\mathrm{NA}$ & 79.4 & 79.4 & $\mathrm{NA}$ & 85.9 & 85.9 & $\mathrm{NA}$ & 77.0 & 77.0 & $\mathrm{NA}$ & 79.4 & 79.4 \\
\hline & $<0.1$ & 11.5 & 11.5 & $<0.1$ & 11.0 & 11.0 & $<0.1$ & 10.4 & 10.4 & $<0.1$ & 27.6 & 27.6 & $<0.1$ & 35.1 & 35.1 \\
\hline Nitrate & $\mathrm{NA}$ & 90.3 & 90.3 & $\mathrm{NA}$ & 78.5 & 78.5 & NA & $\overline{72.5}$ & 72.5 & $\mathrm{NA}$ & 77.9 & 77.9 & $\mathrm{NA}$ & 83.2 & 83.2 \\
\hline Nitrite & $\mathrm{NA}$ & $<0.1$ & $<0.1$ & $\mathrm{NA}$ & $<0.1$ & $<0.1$ & $\mathrm{NA}$ & $<0.1$ & $<0.1$ & $\mathrm{NA}$ & $<0.1$ & $<0.1$ & $\mathrm{NA}$ & $<0.1$ & $<0.1$ \\
\hline Sulfate & 2.8 & 316.52 & 319.3 & 0.3 & 295.49 & 295.8 & 0.2 & 307.6 & 307.8 & $<0.1$ & 288.22 & 288.2 & $<0.1$ & 300.33 & 300.3 \\
\hline
\end{tabular}


The Catholic University of America Vitreous State Laboratory
DuraMelter 1200 Start-Up Tests with AZ-101

Final Report, VSL-01R0100-2, Rev.0

Table 4.4. Analytical Results for Samples of SBS Blowdown Fluids (mg/l). (continued).

\begin{tabular}{|c|c|c|c|c|c|c|c|c|c|c|c|c|c|c|c|}
\hline & \multicolumn{3}{|c|}{$12 \mathrm{E}-\mathrm{S}-139 \mathrm{~A}$} & \multicolumn{3}{|c|}{$12 \mathrm{E}-\mathrm{S}-141 \mathrm{~A}$} & \multicolumn{3}{|c|}{$12 \mathrm{E}-\mathrm{S}-141 \mathrm{~B}$} & \multicolumn{3}{|c|}{$12 \mathrm{E}-\mathrm{S}-142 \mathrm{~A}$} & \multicolumn{3}{|c|}{ 12E-S-142B } \\
\hline flass $(\mathrm{kg})$ & \multicolumn{3}{|c|}{8800} & \multicolumn{3}{|c|}{8850} & \multicolumn{3}{|c|}{8900} & \multicolumn{3}{|c|}{8950} & \multicolumn{3}{|c|}{9000} \\
\hline $\mathrm{pH}$ & \multicolumn{3}{|c|}{3.17} & \multicolumn{3}{|c|}{3.37} & \multicolumn{3}{|c|}{3.67} & \multicolumn{3}{|c|}{3.71} & \multicolumn{3}{|c|}{3.58} \\
\hline & Sus. * & Dis.\# & Total & Sus. & Dis. & Total & Sus. & Dis. & Total & Sus. & \begin{tabular}{|l} 
Dis. \\
\end{tabular} & Total & Sus. & \begin{tabular}{|l} 
Dis. \\
.
\end{tabular} & Total \\
\hline Total & 512 & 1536 & 2048 & 518 & 1616 & 2134 & 555 & 1596 & 2151 & 547 & 1700 & 2247 & 555 & 1400 & 1955 \\
\hline 11 & 14.0 & 42.1 & 56.1 & 15.0 & 42.6 & $\overline{57.5}$ & 17.4 & 43.2 & 60.6 & 16.9 & 44.9 & 61.9 & 15.9 & 45.8 & 61.6 \\
\hline As & 0.4 & 0.9 & 1.3 & 0.4 & 0.8 & 1.2 & 0.6 & 0.9 & 1.5 & 0.5 & 0.9 & 1.4 & 0.5 & 1.0 & 1.5 \\
\hline & 0.8 & 178.1 & 178.9 & 0.9 & 185.8 & 186.6 & 1.0 & 190.6 & 191.5 & 0.9 & 189.3 & 190.2 & 0.9 & 201.9 & 202.8 \\
\hline $\mathrm{Ba}$ & 0.2 & 0.2 & 0.4 & 0.2 & 0.2 & 0.4 & 0.3 & 0.2 & 0.5 & 0.3 & 0.2 & 0.5 & 0.3 & 0.2 & 0.5 \\
\hline $\mathrm{Ca}$ & 0.2 & 12.8 & 13.0 & 0.2 & 12.3 & 12.5 & 0.3 & 11.7 & 12.0 & 0.2 & 11.7 & 12.0 & 0.3 & 11.1 & 11.4 \\
\hline $\mathrm{Cd}$ & 1.0 & 4.8 & 5.8 & 1.1 & 5.0 & 6.0 & 1.3 & 5.0 & 6.3 & 1.3 & 5.1 & 6.4 & 1.3 & 5.1 & 6.4 \\
\hline $\mathrm{Cr}$ & 0.6 & 0.3 & 0.8 & 0.6 & 0.3 & 0.9 & 0.7 & 0.3 & 0.9 & 0.7 & 0.3 & 1.0 & 0.7 & 0.3 & 1.0 \\
\hline $\mathrm{Cs}$ & 0.7 & $\overline{5.4}$ & 6.1 & 0.7 & 5.5 & 6.2 & $\angle 0.1$ & 5.9 & 5.9 & 0.7 & 5.8 & 6.5 & 0.1 & 5.3 & 3 \\
\hline $\mathrm{Cu}$ & 0.1 & 0.3 & 0.4 & 0.1 & 0.3 & 0.4 & 0.1 & 0.3 & 0.4 & 0.1 & 0.3 & 0.5 & 0.1 & 0.3 & 0. \\
\hline $\mathrm{Fe}$ & 91.8 & 0.2 & 92.0 & 93.6 & 0.2 & 93.8 & 99.5 & 0.1 & 99.6 & 100.6 & 0.1 & 100.7 & 101.2 & 0.1 & 101.3 \\
\hline $\bar{K}$ & 0.1 & 5.7 & 5.8 & 0.1 & 5.9 & 6.0 & 0.2 & 6.1 & 6.3 & 0.2 & 6.2 & 6.3 & 0.1 & 6.1 & 6.3 \\
\hline $\mathrm{i}$ & 0.6 & 23.6 & 24.2 & 0.7 & 24.6 & 25.2 & 0.8 & 26.6 & 27.4 & 0.8 & 28.0 & 28.8 & 0.8 & 28.3 & 29.1 \\
\hline $\mathrm{Mg}$ & 0.1 & 3.2 & 3.3 & 0.1 & 3.1 & 3.3 & 0.1 & 3.0 & 3.2 & 0.1 & 2.9 & 3.0 & 0.1 & 2.7 & 2.9 \\
\hline $\mathrm{Mn}$ & 4.0 & 7.0 & 11.0 & 3.9 & 7.1 & 11.0 & 3.8 & 7.4 & 11.1 & 3.5 & 7.6 & 11.1 & 3.5 & 7.5 & 11 \\
\hline $\mathrm{Na}$ & 1.1 & 100.2 & 101.3 & 1.2 & 104.8 & 106.0 & 1.4 & 109.2 & 110.5 & 1.4 & 105.6 & 107.0 & 1.4 & 110.4 & 111.8 \\
\hline $\mathrm{Ni}$ & 4.7 & 1.1 & 5.8 & 4.9 & 1.1 & 6.0 & 5.3 & 1.1 & 6.4 & 5.4 & 1.1 & 6.5 & 5.4 & 1.1 & 6.5 \\
\hline $\mathrm{P}$ & 0.5 & 0.5 & 1.0 & 0.7 & 0.6 & 1.3 & 0.8 & 0.5 & 1.3 & 0.7 & 0.6 & 1.3 & 0.6 & 0.6 & 1.2 \\
\hline $\mathrm{Pb}$ & 1.9 & 0.4 & 2.3 & 1.9 & 0.4 & 2.3 & 2.1 & 0.4 & 2.5 & 2.1 & 0.4 & 2.5 & 2.1 & 0.4 & 2 \\
\hline $\mathrm{Sb}$ & 1.2 & 0.2 & 1.5 & 1.2 & 0.2 & 1.5 & 1.5 & 0.1 & 1.6 & 1.5 & 0.1 & 1.6 & 1.5 & 0.1 & 1 \\
\hline $\mathrm{Se}$ & 30.3 & 255.7 & 286.0 & 30.8 & 225.3 & 256.1 & 32.6 & 252.5 & 285.0 & 32.4 & 252.0 & 284.4 & 32.5 & 244.0 & 276. \\
\hline $\mathrm{Si}$ & 90.3 & 22.7 & 113.0 & 89.8 & 23.4 & 113.1 & 91.3 & 25.1 & 116.4 & 87.2 & 26.1 & \begin{tabular}{|l|}
113.3 \\
\end{tabular} & 87.2 & 25.6 & 112.8 \\
\hline $\mathrm{Sr}$ & 1.3 & 27.3 & 28.6 & 1.3 & 28.5 & 29.8 & 1.4 & 29.8 & 31.2 & 1.4 & 31.8 & 33.1 & 1.5 & 31.8 & 33.3 \\
\hline $\mathrm{Te}$ & 17.7 & 2.3 & 20.0 & 18.1 & 2.4 & 20.6 & 19.6 & 2.2 & 21.8 & 20.5 & 2.3 & 22.8 & 21.6 & 2.5 & 24. \\
\hline $\mathrm{Ti}$ & 0.4 & $<0.1$ & 0.4 & 0.4 & $<0.1$ & 0.4 & 0.4 & $<0.1$ & 0.4 & 0.4 & $<0.1$ & 0.4 & 0.3 & $<0.1$ & 0. \\
\hline $\mathrm{Zn}$ & 3.1 & 24.2 & 27.3 & 3.3 & 24.6 & 27.8 & 3.8 & 26.5 & 30.3 & 3.7 & 26.1 & 29.9 & 3.8 & 26.4 & 30.2 \\
\hline $\mathrm{Zr}$ & 12.2 & 2.1 & 14.4 & 11.8 & 1.6 & 13.4 & 12.5 & 0.8 & 13.3 & 11.3 & 0.9 & 12.1 & 10.5 & 1.5 & 11.9 \\
\hline $\mathrm{Cl}$ & NA & 72.9 & 72.9 & NA & 71.0 & 71.0 & $\mathrm{NA}$ & 76.6 & 76.6 & NA & 74.7 & 74.7 & $\mathrm{NA}$ & 76.2 & 76.2 \\
\hline $\mathrm{F}$ & NA & 83.5 & 83.5 & NA & 78.8 & 78.8 & NA & 85.9 & 85.9 & NA & 87.1 & 87.1 & $\mathrm{NA}$ & 95.6 & 95. \\
\hline & $<0.1$ & 54.4 & 54.4 & $<0.1$ & 64.9 & 64.9 & $<0.1$ & 82.5 & 82.5 & $<0.1$ & 98.7 & 98.7 & $<0.1$ & 96.0 & $\overline{96}$ \\
\hline Nitrate & NA & 84.5 & 84.5 & NA & 84.5 & 84.5 & $\mathrm{NA}$ & 81.2 & 81.2 & NA & 81.9 & 81.9 & $\mathrm{NA}$ & 77.4 & 77. \\
\hline Nitrite & NA & $<0.1$ & $<0.1$ & NA & $<0.1$ & $<0.1$ & $\mathrm{NA}$ & $<0.1$ & $<0.1$ & NA & $<0.1$ & $<0.1$ & $\mathrm{NA}$ & $<0.1$ & $<0.1$ \\
\hline Sulfate & 1.1 & 295.49 & 296.6 & 0.2 & 300.33 & 300.5 & $<0.1$ & 329.41 & 329.4 & 0.6 & 341.52 & 342.1 & $<0.1$ & 362.76 & 362.8 \\
\hline
\end{tabular}


The Catholic University of America Vitreous State Laboratory
DuraMelter 1200 Start-Up Tests with AZ-101

Final Report, VSL-01R0100-2, Rev.0

Table 4.4. Analytical Results for Samples of SBS Blowdown Fluids (mg/l). (continued).

\begin{tabular}{|c|c|c|c|c|c|c|c|c|c|c|c|c|}
\hline & \multicolumn{3}{|c|}{ 12E-S-147A } & \multicolumn{3}{|c|}{ 12E-S-147B } & \multicolumn{3}{|c|}{$12 \mathrm{E}-\mathrm{S}-147 \mathrm{C}$} & \multicolumn{3}{|c|}{ 12E-S-149A } \\
\hline Glass (kg) & \multicolumn{3}{|c|}{9200} & \multicolumn{3}{|c|}{9250} & \multicolumn{3}{|c|}{9300} & \multicolumn{3}{|c|}{9350} \\
\hline $\mathrm{pH}$ & \multicolumn{3}{|c|}{3.54} & \multicolumn{3}{|c|}{3.61} & \multicolumn{3}{|c|}{3.60} & \multicolumn{3}{|c|}{3.53} \\
\hline & Sus.* & Dis.\# & Total & Sus. & Dis. & Total & Sus. & Dis. & Total & Sus. & Dis. & \begin{tabular}{|l|} 
Total \\
\end{tabular} \\
\hline Total & 558 & 1404 & 1962 & 579 & 1428 & 2007 & 577 & 1512 & 2089 & 580 & 1636 & 2216 \\
\hline $\mathrm{Al}$ & 16.2 & 44.8 & 61.0 & 16.4 & 45.6 & 62.0 & 16.0 & 46.8 & 62.8 & 15.8 & 47.0 & 62.8 \\
\hline As & 0.5 & 0.9 & 1.5 & 0.6 & 0.9 & 1.5 & 0.6 & 1.1 & 1.7 & 0.6 & 1.0 & 1.6 \\
\hline B & 0.9 & 209.3 & 210.2 & 1.0 & 210.3 & 211.3 & 1.3 & 219.2 & 220.5 & 1.1 & 225.6 & 226.7 \\
\hline $\mathrm{Ba}$ & 0.3 & 0.2 & 0.5 & 0.4 & 0.2 & 0.5 & 0.3 & 0.2 & 0.5 & 0.4 & 0.2 & 0.6 \\
\hline $\mathrm{Ca}$ & 0.3 & 10.4 & 10.7 & 0.3 & 10.1 & 10.3 & 0.3 & 9.9 & 10.2 & 0.5 & 9.5 & 10.0 \\
\hline $\mathrm{Cd}$ & 1.3 & 5.4 & 6.7 & 1.4 & 5.4 & 6.8 & 1.4 & 5.6 & 7.0 & 1.4 & 5.6 & 7.0 \\
\hline $\mathrm{Cr}$ & 0.7 & 0.3 & 1.0 & 0.8 & 0.3 & 1.1 & 0.8 & 0.3 & 1.1 & 0.9 & 0.3 & 1.1 \\
\hline $\mathrm{Cs}$ & 1.2 & 5.6 & 6.8 & $<0.1$ & 5.7 & 5.7 & $<0.1$ & 6.1 & 6.1 & 0.9 & 6.2 & 7.1 \\
\hline $\mathrm{Cu}$ & 0.1 & 0.4 & 0.5 & 0.1 & 0.3 & 0.4 & 0.1 & 0.4 & 0.5 & 0.1 & 0.3 & 0.5 \\
\hline $\mathrm{Fe}$ & 102.0 & 0.2 & 102.2 & 107.5 & 0.1 & 107.6 & 106.6 & 0.2 & 106.7 & 111.4 & 0.1 & 111.6 \\
\hline K & 0.1 & 12.1 & 12.2 & 0.2 & 6.4 & 6.6 & 0.3 & 6.5 & 6.9 & 0.2 & 9.2 & 9.4 \\
\hline $\mathrm{Li}$ & 0.8 & 28.8 & 29.5 & 0.8 & 29.8 & 30.6 & 0.8 & 27.7 & 28.5 & 0.9 & 28.4 & 29.3 \\
\hline $\mathrm{Mg}$ & 0.1 & 2.6 & 2.8 & 0.2 & 2.5 & 2.7 & 0.2 & 2.4 & 2.6 & 0.2 & 2.3 & 2.5 \\
\hline $\mathrm{Mn}$ & 3.8 & 7.7 & 11.5 & 4.0 & 7.9 & 11.9 & 3.8 & 8.4 & 12.2 & 3.8 & 8.3 & 12.1 \\
\hline $\mathrm{Na}$ & 1.4 & 112.7 & 114.1 & 1.4 & 113.2 & 114.6 & 1.4 & 115.5 & 116.9 & 1.6 & 117.2 & 118.8 \\
\hline $\mathrm{Ni}$ & 5.4 & 1.1 & 6.5 & 5.7 & 1.1 & 6.8 & 5.7 & 1.1 & 6.8 & 5.9 & 1.1 & 7.0 \\
\hline P & 0.7 & 0.6 & 1.4 & 0.8 & 0.5 & 1.3 & 0.8 & 0.4 & 1.2 & 0.7 & 0.6 & 1.3 \\
\hline $\mathrm{Pb}$ & 2.2 & 0.4 & 2.6 & 2.3 & 0.4 & 2.7 & 2.3 & 0.5 & 2.7 & 2.3 & 0.5 & 2.8 \\
\hline $\mathrm{Sb}$ & 1.6 & 0.1 & 1.7 & 1.7 & 0.1 & 1.8 & 1.6 & 0.2 & 1.9 & 1.7 & 0.1 & 1.9 \\
\hline $\mathrm{Se}$ & 33.1 & 243.0 & 276.1 & 35.1 & 242.7 & 277.9 & 33.2 & 241.6 & 274.9 & 33.4 & 235.0 & 268.4 \\
\hline $\mathrm{Si}$ & 92.1 & 25.8 & 117.9 & 95.5 & 26.6 & 122.1 & 94.5 & 27.4 & \begin{tabular}{|l|l}
121.9 \\
\end{tabular} & 79.0 & 27.3 & 106.3 \\
\hline $\mathrm{Sr}$ & 1.5 & 30.8 & 32.3 & 1.6 & 31.7 & 33.2 & 1.6 & 32.1 & 33.6 & 1.7 & 32.1 & 33.8 \\
\hline $\mathrm{Te}$ & 22.5 & 2.8 & 25.3 & 24.0 & 2.8 & 26.8 & 24.2 & 2.6 & 26.8 & 24.1 & 2.8 & 26.9 \\
\hline Ti & 0.4 & $<0.1$ & 0.4 & 0.4 & $<0.1$ & 0.4 & 0.3 & $<0.1$ & 0.3 & 0.4 & $<0.1$ & 0.4 \\
\hline $\mathrm{Zn}$ & 3.8 & 27.1 & 30.9 & 3.9 & 27.2 & 31.1 & 3.8 & 28.0 & 31.8 & 3.9 & 27.5 & 31.4 \\
\hline $\mathrm{Zr}$ & 11.7 & 1.6 & 13.3 & 12.1 & 1.6 & 13.6 & 10.8 & 2.0 & 12.8 & 11.0 & 2.0 & 13.1 \\
\hline $\mathrm{Cl}$ & NA & 85.6 & 85.6 & $\mathrm{NA}$ & 90.4 & 90.4 & $\mathrm{NA}$ & 79.0 & 79.0 & $\mathrm{NA}$ & 83.7 & 83.7 \\
\hline $\mathrm{F}$ & NA & 99.9 & 99.9 & NA & 104.2 & 104.2 & $\mathrm{NA}$ & 103.0 & 103.0 & $\mathrm{NA}$ & 106.0 & 106.0 \\
\hline ] & $<0.1$ & 109.5 & 109.5 & $<0.1$ & 106.8 & 106.8 & $<0.1$ & 108.1 & 108.1 & $<0.1$ & 104.1 & 104.1 \\
\hline Nitrate & NA & 69.9 & 69.9 & NA & 65.9 & 65.9 & $\overline{\mathrm{NA}}$ & 61.8 & 61.8 & NA & 59.8 & 59.8 \\
\hline Nitrite & NA & $<0.1$ & $<0.1$ & NA & $<0.1$ & $<0.1$ & $\mathrm{NA}$ & $<0.1$ & $<0.1$ & $\mathrm{NA}$ & $<0.1$ & $<0.1$ \\
\hline Sulfate & 0.6 & 374.8 & 375.4 & 0.3 & $\begin{array}{r}377.2 \\
1\end{array}$ & 377.5 & 1.4 & $\begin{array}{r}379.6 \\
2\end{array}$ & 381.0 & 0.6 & $\begin{array}{r}379.6 \\
2\end{array}$ & 380.2 \\
\hline
\end{tabular}


The Catholic University of America Vitreous State Laboratory
DuraMelter 1200 Start-Up Tests with AZ-101

Final Report, VSL-01R0100-2, Rev.0

Table 4.4. Analytical Results for Samples of SBS Blowdown Fluids (mg/l). (continued).

\begin{tabular}{|c|c|c|c|c|c|c|c|c|c|c|c|c|c|c|c|}
\hline & \multicolumn{3}{|c|}{$12 \mathrm{~F}-\mathrm{S}-10 \mathrm{~A}$} & \multicolumn{3}{|c|}{$12 \mathrm{~F}-\mathrm{S}-11 \mathrm{~A}$} & \multicolumn{3}{|c|}{$12 \mathrm{~F}-\mathrm{S}-13 \mathrm{~A}$} & \multicolumn{3}{|c|}{$12 \mathrm{~F}-\mathrm{S}-14 \mathrm{~A}$} & \multicolumn{3}{|c|}{$12 \mathrm{~F}-\mathrm{S}-14 \mathrm{~B}$} \\
\hline Glass (kg) & \multicolumn{3}{|c|}{9400} & \multicolumn{3}{|c|}{9500} & \multicolumn{3}{|c|}{9636} & \multicolumn{3}{|c|}{9650} & \multicolumn{3}{|c|}{9700} \\
\hline$\overline{\mathrm{PH}}$ & \multicolumn{3}{|c|}{3.42} & \multicolumn{3}{|c|}{3.53} & \multicolumn{3}{|c|}{3.58} & \multicolumn{3}{|c|}{3.34} & \multicolumn{3}{|c|}{3.31} \\
\hline & Sus. ${ }^{*}$ & Dis.\# & Total & Sus. & Dis. & Total & Sus. & Dis. & Total & Sus. & Dis. & Total & Sus. & Dis. & Total \\
\hline Total & 503 & 1532 & 2035 & 512 & 1512 & 2024 & 500 & 1572 & 2072 & 453 & 1528 & 1981 & 505 & 1520 & 2025 \\
\hline$\overline{\mathrm{Al}}$ & 12.5 & 50.4 & 62.9 & 13.1 & 49.7 & 62.8 & 13.0 & 49.2 & 62.2 & 10.1 & 48.8 & 58.9 & 11.7 & 49.8 & 61. \\
\hline As & 0.5 & 1.1 & 1.6 & 0.5 & 1.2 & 1.7 & 0.5 & 1.0 & 1.5 & 0.4 & 1.0 & 1.4 & 0.5 & 1.2 & 1. \\
\hline$B$ & 0.9 & 218.4 & 219.3 & 0.9 & 214.7 & 215.6 & 0.8 & 216.0 & 216.8 & 0.8 & 221.1 & 221.9 & 0.9 & 218.9 & 219.8 \\
\hline $\mathrm{Ba}$ & 0.3 & 0.2 & 0.5 & 0.3 & 0.2 & 0.5 & 0.3 & 0.2 & 0.5 & 0.3 & 0.2 & 0.5 & 0.3 & 0.2 & 0.5 \\
\hline $\mathrm{Ca}$ & 0.3 & 9.3 & 9.6 & 0.3 & 8.9 & 9.2 & 0.2 & 8.6 & 8.8 & 0.2 & 8.3 & 8.5 & 0.2 & 8.2 & 0. \\
\hline $\mathrm{Cd}$ & 1.2 & 5.7 & 6.9 & 1.2 & 5.7 & 6.9 & 1.2 & 5.8 & 7.0 & 1.0 & 5.7 & 6.7 & 1.1 & 5.7 & 6. \\
\hline $\mathrm{Cr}$ & 0.8 & 0.3 & 1.1 & 0.8 & 0.3 & 1.1 & 0.7 & 0.3 & 1.1 & 0.7 & 0.3 & 1.0 & 0.8 & 0.3 & 1. \\
\hline $\mathrm{Cs}$ & 0.7 & 5.9 & 6.6 & 0.7 & 5.7 & 6.4 & 0.9 & 6.2 & 7.1 & 0.5 & 6.1 & 6.6 & 0.7 & 6.5 & 7. \\
\hline $\mathrm{Cu}$ & 0.1 & 0.3 & 0.4 & 0.1 & 0.3 & 0.4 & 0.1 & 0.3 & 0.4 & 0.1 & 0.3 & 0.4 & 0.1 & 0.3 & 0.4 \\
\hline $\mathrm{Fe}$ & 96.3 & 0.2 & 96.5 & 97.5 & 0.2 & 97.6 & 94.1 & 0.2 & 94.2 & 89.0 & 0.3 & 89.3 & 94.8 & 0.3 & 95. \\
\hline $\mathrm{K}$ & 0.1 & 6.4 & 6.5 & 0.1 & 6.4 & 6.5 & 0.1 & 6.5 & 6.6 & 0.1 & 6.1 & 6.2 & $\overline{0.1}$ & 6.2 & 6.3 \\
\hline $\mathrm{Li}$ & 0.7 & $\overline{30.9}$ & 31.6 & 0.7 & 30.5 & 31.2 & 0.7 & 30.6 & 31.3 & 0.6 & 29.8 & 30.5 & $\overline{0.7}$ & 30.9 & 31. \\
\hline $\mathrm{Mg}$ & 0.1 & 2.1 & 2.2 & 0.1 & 2.1 & 2.2 & 0.1 & 2.0 & 2.2 & 0.1 & 1.9 & 2.0 & 0.1 & 1.9 & $\sqrt{7}$ \\
\hline $\mathrm{Mn}$ & 3.5 & 8.3 & 11.8 & 3.5 & 8.1 & 11.6 & 3.5 & 8.0 & 11.5 & 2.9 & 7.8 & 10.8 & $\overline{3.5}$ & 7.9 & 11. \\
\hline $\mathrm{Na}$ & 1.3 & 112.9 & 114.2 & 1.2 & 111.0 & 112.3 & 1.2 & 112.2 & 113.4 & 1.1 & \begin{tabular}{|l|}
111.2 \\
\end{tabular} & 112.3 & 1.2 & 109.3 & 110. \\
\hline $\mathrm{Ni}$ & 5.2 & 1.2 & 6.4 & 5.5 & 1.2 & 6.7 & 5.1 & 1.3 & 6.4 & 4.6 & 1.2 & 5.8 & 5.3 & 1.1 & 6. \\
\hline $\bar{P}$ & 0.5 & 0.6 & 1.1 & 0.5 & 0.7 & 1.2 & 0.5 & 0.9 & 1.3 & 0.6 & 0.7 & 1.3 & $\overline{0.6}$ & 0.6 & - \\
\hline $\mathrm{Pb}$ & 1.9 & 0.7 & 2.6 & 2.0 & 0.7 & 2.7 & 1.9 & 0.7 & 2.6 & 1.8 & 0.7 & 2.5 & 2.0 & 0.7 & 2. \\
\hline $\mathrm{Sb}$ & 1.4 & 0.2 & 1.6 & 1.5 & 0.2 & 1.6 & 1.4 & 0.2 & 1.6 & 1.2 & 0.2 & 1.4 & 1.4 & 0.3 & 1. \\
\hline $\mathrm{Se}$ & 31.3 & 255.8 & 287.0 & 30.5 & 236.9 & 267.4 & 29.7 & 234.6 & 264.3 & 28.4 & \begin{tabular}{|l|}
246.3 \\
\end{tabular} & 274.6 & 32.1 & 240.9 & 273. \\
\hline $\mathrm{Si}$ & 82.4 & 25.1 & 107.5 & 83.1 & 23.5 & 106.5 & 82.6 & 23.0 & 105.6 & 73.1 & 22.6 & 95.8 & 79.1 & 23.3 & 102 \\
\hline $\mathrm{Sr}$ & 1.5 & 34.2 & 35.7 & 1.6 & 33.5 & 35.1 & 1.5 & 33.7 & 35.1 & 1.4 & 32.5 & 33.9 & 1.5 & 32.8 & 34 \\
\hline $\mathrm{Te}$ & 22.4 & 2.9 & 25.3 & 24.0 & 2.8 & 26.8 & 22.6 & 2.7 & 25.3 & 21.8 & 3.2 & 24.9 & 24.2 & 3.2 & 27. \\
\hline $\mathrm{Ti}$ & 0.3 & $<0.1$ & 0.3 & 0.4 & $<0.1$ & 0.4 & 0.3 & $<0.1$ & 0.3 & 0.3 & $<0.1$ & 0.3 & 0.3 & $<0.1$ & 0 \\
\hline $\mathrm{Zn}$ & 3.4 & 27.8 & 31.2 & 3.4 & 27.1 & 30.5 & 3.3 & 27.0 & 30.3 & 3.1 & 26.4 & 29.4 & 3.4 & 25.4 & 28. \\
\hline $\mathrm{Zr}$ & 8.7 & 2.2 & 10.9 & 9.2 & 2.1 & 11.2 & 9.0 & 2.0 & 11.0 & 6.7 & 2.5 & 9.2 & 8.2 & 2.5 & 10 \\
\hline$\overline{\mathrm{Cl}}$ & NA & $\overline{76.9}$ & 76.9 & NA & 78.1 & 78.1 & NA & 79.3 & 79.3 & NA & 73.1 & 73.1 & $\overline{\mathrm{NA}}$ & 66.2 & 66. \\
\hline $\mathrm{F}$ & $\mathrm{NA}$ & 109.1 & 109.1 & NA & 105.6 & 105.6 & $\mathrm{NA}$ & 105.6 & 105.6 & $\mathrm{NA}$ & 99.4 & 99.4 & $\overline{\mathrm{NA}}$ & 107.1 & 107 \\
\hline I & $<0.1$ & 90.04 & 90.0 & $<0.1$ & 92.37 & 92.4 & $<0.1$ & \begin{tabular}{|l|}
92.37 \\
\end{tabular} & 92.4 & $<0.1$ & 75.2 & 75.2 & $<0.1$ & 79.0 & 79 \\
\hline Nitrate & NA & 61.1 & 61.1 & NA & 59.4 & 59.4 & $\mathrm{NA}$ & 61.2 & 61.2 & $\mathrm{NA}$ & 46.6 & 46.6 & $\overline{\mathrm{NA}}$ & 51.7 & 51. \\
\hline Nitrite & $\mathrm{NA}$ & $<0.1$ & $<0.1$ & NA & $<0.1$ & $<0.1$ & $\mathrm{NA}$ & $<0.1$ & $<0.1$ & NA & $<0.1$ & $<0.1$ & $\mathrm{NA}$ & $<0.1$ & $<0.1$ \\
\hline Sulfate & 1.4 & 412.83 & 414.2 & 0.8 & 390.53 & 391.3 & 0.8 & 390.53 & 391.3 & & 423.34 & 424.3 & 0.5 & 360.41 & 360. \\
\hline
\end{tabular}


The Catholic University of America Vitreous State Laboratory
DuraMelter 1200 Start-Up Tests with AZ-101

Final Report, VSL-01R0100-2, Rev.0

Table 4.4. Analytical Results for Samples of SBS Blowdown Fluids (mg/l). (continued).

\begin{tabular}{|c|c|c|c|c|c|c|c|c|c|c|c|c|}
\hline & \multicolumn{3}{|c|}{$12 \mathrm{~F}-\mathrm{S}-16 \mathrm{~A}$} & \multicolumn{3}{|c|}{$12 \mathrm{~F}-\mathrm{S}-17 \mathrm{~A}$} & \multicolumn{3}{|c|}{$12 \mathrm{~F}-\mathrm{S}-20 \mathrm{~A}$} & \multicolumn{3}{|c|}{$12 \mathrm{~F}-\mathrm{S}-20 \mathrm{~B}$} \\
\hline Glass $(\mathrm{kg})$ & \multicolumn{3}{|c|}{9750} & \multicolumn{3}{|c|}{9800} & \multicolumn{3}{|c|}{9850} & \multicolumn{3}{|c|}{9900} \\
\hline $\mathrm{pH}$ & \multicolumn{3}{|c|}{3.46} & \multicolumn{3}{|c|}{3.47} & \multicolumn{3}{|c|}{3.77} & \multicolumn{3}{|c|}{3.99} \\
\hline & Sus.* & Dis.\# & Total & Sus. & Dis. & Total & Sus. & Dis. & Total & Sus. & Dis. & Total \\
\hline Total & 528 & 1452 & 1980 & 568 & 1412 & 1980 & 585 & 1600 & 2185 & 649 & 1448 & 2097 \\
\hline$\overline{\mathrm{Al}}$ & 13.3 & 50.5 & 63.9 & 14.0 & 51.2 & 65.2 & 15.9 & 51.4 & 67.3 & 19.7 & 51.0 & 70.8 \\
\hline As & 0.6 & 1.2 & 1.7 & 0.6 & 1.1 & 1.8 & 0.7 & 1.2 & 1.9 & 0.8 & 1.1 & 1.8 \\
\hline $\bar{B}$ & 0.9 & 223.4 & 224.3 & 1.1 & 229.5 & 230.6 & 1.1 & 227.1 & 228.1 & 1.3 & 234.2 & 235.5 \\
\hline $\mathrm{Ba}$ & 0.3 & 0.2 & 0.5 & 0.4 & 0.2 & 0.5 & 0.3 & 0.2 & 0.5 & 0.3 & 0.2 & 0.5 \\
\hline $\mathrm{Ca}$ & 0.2 & 7.9 & 8.1 & 0.3 & 7.8 & 8.1 & 0.3 & 8.1 & 8.3 & 0.3 & 7.7 & 8.0 \\
\hline$\overline{\mathrm{Cd}}$ & 1.2 & $\overline{5.9}$ & 7.1 & 1.3 & 6.1 & 7.4 & 1.4 & 6.0 & 7.5 & 1.7 & 6.0 & 7.7 \\
\hline $\mathrm{Cr}$ & 0.8 & 0.3 & 1.2 & 0.9 & 0.3 & 1.2 & 1.0 & 0.3 & 1.3 & 1.1 & 0.2 & 1.3 \\
\hline$\overline{C s}$ & 0.4 & 6.7 & 7.1 & 0.9 & 7.4 & 8.3 & 1.2 & 6.9 & 8.1 & 1.6 & 7.2 & 8.8 \\
\hline$\overline{\mathrm{Cu}}$ & 0.1 & 0.3 & 0.4 & 0.1 & 0.3 & 0.4 & 0.1 & 0.3 & 0.4 & 0.1 & 0.3 & 0.5 \\
\hline $\mathrm{Fe}$ & 100.7 & 0.2 & 101.0 & 106.7 & 0.2 & 107.0 & 104.5 & 0.1 & 104.6 & 120.2 & 0.1 & 120.2 \\
\hline $\mathrm{K}$ & 0.2 & 6.1 & 6.3 & 0.1 & 6.1 & 6.3 & 0.1 & 6.4 & 6.5 & 0.2 & 6.4 & 6.6 \\
\hline $\mathrm{Li}$ & 0.8 & 31.7 & 32.5 & 0.8 & 32.1 & 33.0 & 0.9 & 33.5 & 34.4 & 1.0 & 35.0 & 36.0 \\
\hline$\overline{\mathrm{Mg}}$ & 0.1 & $\overline{1.8}$ & 2.0 & 0.2 & 1.8 & 1.9 & 0.2 & 1.7 & 1.9 & 0.2 & 1.7 & 1.9 \\
\hline $\mathrm{Mn}$ & 3.5 & 8.0 & 11.5 & 3.9 & 8.0 & 11.9 & 4.1 & 8.5 & 12.6 & 4.6 & 8.0 & 12.7 \\
\hline $\mathrm{Na}$ & 1.3 & 111.1 & 112.4 & 1.4 & 114.5 & 115.9 & 1.6 & 116.3 & 117.9 & 1.9 & 120.3 & 122.2 \\
\hline $\mathrm{Ni}$ & 5.3 & $\overline{1.2}$ & 6.5 & 6.0 & 1.2 & 7.1 & 5.7 & 1.3 & 7.0 & 6.6 & 1.3 & 7.9 \\
\hline P & 0.5 & 1.0 & 1.4 & 0.8 & 0.9 & 1.7 & 0.7 & 1.1 & 1.8 & 0.8 & 1.1 & 1.8 \\
\hline $\mathrm{Pb}$ & 2.2 & 0.7 & 2.8 & 2.2 & 0.7 & 2.9 & 2.1 & 0.7 & 2.9 & 2.3 & 0.8 & 3.1 \\
\hline $\mathrm{Sb}$ & 0.3 & 0.2 & 0.6 & 1.6 & 0.2 & 1.9 & 1.6 & 0.2 & 1.8 & 1.8 & 0.2 & 1.9 \\
\hline $\mathrm{Se}$ & 30.5 & 247.1 & 277.5 & 37.0 & 238.8 & 275.7 & 37.7 & 246.7 & 284.4 & 40.7 & 219.3 & 260.0 \\
\hline $\mathrm{Si}$ & 86.2 & 23.5 & 109.7 & 91.3 & 23.4 & 114.7 & 93.5 & 25.1 & 118.6 & 105.8 & 24.5 & 130.2 \\
\hline $\mathrm{Sr}$ & 1.4 & 33.0 & 34.4 & 1.8 & 33.7 & 35.5 & 1.8 & 36.0 & 37.8 & 2.0 & 37.0 & 38.9 \\
\hline $\mathrm{Te}$ & 24.5 & $\overline{2.9}$ & 27.4 & 26.8 & 2.8 & 29.6 & 27.2 & 2.2 & 29.3 & 29.6 & 2.1 & 31.6 \\
\hline $\mathrm{Ti}$ & 0.3 & $<0.1$ & 0.3 & 0.4 & $<0.1$ & 0.4 & 0.4 & $<0.1$ & 0.4 & 0.4 & $<0.1$ & 0.4 \\
\hline$\overline{Z n}$ & 3.6 & 25.7 & 29.2 & 3.8 & 25.9 & 29.7 & 3.9 & 27.7 & 31.6 & 4.4 & 28.0 & 32.4 \\
\hline $\mathrm{Zr}$ & 9.4 & 2.3 & 11.7 & 9.5 & 2.2 & 11.7 & 10.6 & 1.0 & 11.6 & 12.4 & 0.4 & 12.8 \\
\hline $\mathrm{Cl}$ & NA & 77.5 & 77.5 & NA & 79.4 & 79.4 & $\mathrm{NA}$ & 75.0 & 75.0 & NA & 78.8 & 78.8 \\
\hline F & $\overline{\mathrm{NA}}$ & 105.4 & 105.4 & NA & 107.1 & 107.1 & NA & 107.1 & 107.1 & NA & 101.1 & 101.1 \\
\hline I & $<0.1$ & 81.2 & 81.2 & $<0.1$ & 86.5 & 86.5 & $<0.1$ & 120.5 & 120.5 & $<0.1$ & 111.4 & 111.4 \\
\hline Nitrate & $\overline{\mathrm{NA}}$ & $\overline{51.7}$ & 51.7 & NA & 50.7 & 50.7 & NA & 51.2 & 51.2 & NA & 60.3 & 60.3 \\
\hline Nitrite & $\mathrm{NA}$ & $<0.1$ & $<0.1$ & NA & $<0.1$ & $<0.1$ & $\mathrm{NA}$ & $<0.1$ & $<0.1$ & NA & $<0.1$ & $<0.1$ \\
\hline Sulfate & & 401.32 & 402.3 & 0.5 & 423.34 & 423.8 & 1.3 & 410.76 & 412.1 & 1.4 & 439.08 & 440.5 \\
\hline
\end{tabular}


The Catholic University of America Vitreous State Laboratory
DuraMelter 1200 Start-Up Tests with AZ-101

Final Report, VSL-01R0100-2, Rev.0

Table 4.4. Analytical Results for Samples of SBS Blowdown Fluids (mg/l). (continued).

\begin{tabular}{|c|c|c|c|c|c|c|c|c|c|c|c|c|}
\hline & \multicolumn{3}{|c|}{$12 \mathrm{~F}-\mathrm{S}-25 \mathrm{~A}$} & \multicolumn{3}{|c|}{$12 \mathrm{~F}-\mathrm{S}-25 \mathrm{~B}$} & \multicolumn{3}{|c|}{$12 \mathrm{~F}-\mathrm{S}-27 \mathrm{~A}$} & \multicolumn{3}{|c|}{$12 \mathrm{~F}-\mathrm{S}-28 \mathrm{~A}$} \\
\hline Glass (kg) & \multicolumn{3}{|c|}{10000} & \multicolumn{3}{|c|}{10050} & \multicolumn{3}{|c|}{10150} & \multicolumn{3}{|c|}{10200} \\
\hline $\mathrm{pH}$ & \multicolumn{3}{|c|}{3.75} & \multicolumn{3}{|c|}{3.64} & \multicolumn{3}{|c|}{3.68} & \multicolumn{3}{|c|}{3.84} \\
\hline & Sus. * * & Dis.\# & Total & Sus. & Dis. & Total & Sus. & Dis. & Total & Sus. & Dis. & Total \\
\hline otal & 590 & 1508 & 2098 & 555 & 1452 & 2007 & 582 & 1584 & 2166 & 560 & & 560 \\
\hline 1 & 16.0 & 50.3 & 66.3 & 14.1 & 51.2 & 65.4 & 14.1 & 50.3 & 64.4 & 15.4 & 50.4 & 65.8 \\
\hline is & 0.7 & 1.0 & 1.7 & 0.7 & 1.2 & 1.9 & 0.7 & 0.9 & 1.7 & 0.8 & 0.9 & 1 \\
\hline B & 1.2 & 234.7 & 235.9 & 1.1 & 211.0 & 212.1 & 1.0 & 240.2 & 241.2 & 1.1 & 244.6 & 245. \\
\hline $\mathrm{Ba}$ & 0.3 & 0.2 & 0.5 & 0.3 & 0.2 & 0.5 & 0.3 & 0.2 & 0.5 & 0.3 & 0.2 & 0.5 \\
\hline $\mathrm{Ca}$ & 0.3 & 7.3 & 7.5 & 0.3 & 6.9 & 7.2 & 0.2 & 6.8 & 7.0 & 0.3 & 6.7 & 7.0 \\
\hline $\mathrm{Cd}$ & 1.5 & 6.2 & 7.7 & 1.4 & 5.8 & 7.2 & 1.4 & 5.9 & 7.3 & 1.4 & 6.0 & 7. \\
\hline $\mathrm{Cr}$ & 1.0 & 0.3 & 1.3 & 1.0 & 0.3 & 1.3 & 1.0 & 0.3 & 1.2 & 1.0 & 0.2 & 1 . \\
\hline $\mathrm{s}$ & 0.7 & 7.0 & 7.7 & 0.7 & 6.4 & 7.1 & $<0.1$ & 6.7 & 6.7 & $<0.1$ & 6.9 & 6. \\
\hline $\mathrm{Cu}$ & 0.1 & 0.3 & 0.4 & 0.1 & 0.3 & 0.4 & 0.1 & 0.3 & 0.4 & 0.1 & 0.3 & 0. \\
\hline $\mathrm{Fe}$ & 110.0 & 0.1 & 110.1 & 104.6 & 0.1 & 104.8 & 102.6 & 0.1 & 02.7 & 100.6 & $\overline{0.1}$ & 00.7 \\
\hline $\mathrm{K}$ & 0.2 & 6.3 & 6.5 & 0.1 & 6.1 & 6.2 & 0.1 & 7.0 & 7.1 & 0.1 & 6.2 & 0.3 \\
\hline $\mathrm{Li}$ & 0.9 & 34.2 & 35.1 & 0.9 & 34.0 & 34.9 & 0.9 & 34.8 & 35.7 & 0.9 & 34.6 & 35. \\
\hline$\overline{\mathrm{Mg}}$ & 0.2 & 1.6 & 1.8 & 0.2 & 1.5 & 1.7 & 0.2 & 1.5 & 1.7 & 0.1 & 1.5 & 1. \\
\hline $\mathrm{Mn}$ & 4.1 & 8.0 & 12.1 & 3.8 & 7.6 & 11.4 & 4.3 & 7.8 & 12.1 & 3.7 & 7.7 & 11. \\
\hline $\mathrm{Na}$ & 1.7 & 118.1 & 119.7 & 1.5 & 103.0 & 104.4 & 1.5 & 118.0 & 119.5 & 1.7 & 119.9 & 121.5 \\
\hline $\mathrm{Ni}$ & 5.8 & 1.2 & 7.0 & 5.7 & 1.1 & 6.8 & 5.8 & 1.2 & 7.0 & 5.7 & 1.1 & 6.9 \\
\hline $\mathrm{P}$ & 0.7 & 0.9 & 1.6 & 0.6 & 1.1 & 1.7 & 0.6 & 1.0 & 1.6 & 0.8 & 1.0 & 1. \\
\hline $\mathrm{Pb}$ & 2.2 & 0.8 & 2.9 & 2.1 & 0.7 & 2.8 & 2. & 0.8 & 2.9 & 2.1 & 0.8 & 2. \\
\hline $\mathrm{Sb}$ & 1.6 & 0.2 & 1.8 & 1.6 & 0.2 & 1.8 & 1.7 & 0.2 & 1.8 & 1.6 & 0.3 & 1. \\
\hline $\mathrm{Se}$ & 38.2 & 249.3 & 287.5 & 36.2 & 216.1 & 252.3 & 37.6 & 271.2 & 308.7 & 38.0 & 238.9 & 276 \\
\hline$\overline{\mathrm{Si}}$ & 81.3 & 24.5 & 105.8 & 89.4 & 23.9 & 113.3 & 95.6 & 24.8 & 120.3 & 87.0 & 24.7 & 111. \\
\hline $\mathrm{Sr}$ & 1.8 & 35.1 & 36.9 & 1.7 & 34.7 & 36.4 & 1.7 & 34.2 & \begin{tabular}{|l|}
35.9 \\
\end{tabular} & 1.8 & 34.9 & 36. \\
\hline $\mathrm{Te}$ & 27.1 & 2.2 & 29.3 & 26.6 & 2.4 & 29.0 & 27.2 & 2.3 & 29.5 & 25.3 & 2.1 & 27. \\
\hline Ti & 0.4 & $<0.1$ & 0.4 & 0.3 & $<0.1$ & 0.3 & 0.4 & $<0.1$ & 0.4 & 0.3 & $<0.1$ & 0. \\
\hline $\mathrm{Zn}$ & 3.9 & 27.2 & 31.2 & 3.7 & 27.8 & 31.5 & 3.8 & 28.8 & 32.5 & 3.7 & 28.4 & 32. \\
\hline $\mathrm{Zr}$ & 9.9 & 1.1 & 11.0 & 9.2 & 1.5 & 10.7 & 11.0 & 1.3 & 12.3 & 9.7 & 0.7 & 10. \\
\hline $\mathrm{Cl}$ & NA & 87.6 & 87.6 & $\mathrm{NA}$ & 78.8 & 78.8 & NA & 76.3 & \begin{tabular}{|l|}
76.3 \\
\end{tabular} & NA & 78.2 & 78. \\
\hline $\mathrm{F}$ & $\mathrm{NA}$ & 100.2 & 100.2 & NA & 99.4 & 99.4 & NA & 100.9 & 100.9 & NA & 100.9 & 100. \\
\hline & $<0.1$ & 125.3 & 125.3 & $<0.1$ & 103.3 & 103.3 & $<0.1$ & 109.9 & 109.9 & $<0.1$ & 131.9 & 131. \\
\hline Nitrate & NA & 51.1 & 51.1 & $\mathrm{NA}$ & 45.9 & 45.9 & NA & 44.2 & \begin{tabular}{|l|}
44.2 \\
\end{tabular} & NA & 42.5 & 42. \\
\hline Nitrite & NA & $<0.1$ & $<0.1$ & $\mathrm{NA}$ & $<0.1$ & $<0.1$ & NA & $<0.1$ & $<0.1$ & NA & $<0.1$ & $<0.1$ \\
\hline Sulfate & 0.94 & 411.72 & 412.6 & 0.5 & 390.53 & 391.0 & & 408.69 & 409.6 & & 420.79 & 421. \\
\hline
\end{tabular}


The Catholic University of America Vitreous State Laboratory
DuraMelter 1200 Start-Up Tests with AZ-101

Final Report, VSL-01R0100-2, Rev.0

Table 4.4. Analytical Results for Samples of SBS Blowdown Fluids (mg/l). (continued).

\begin{tabular}{|c|c|c|c|c|c|c|c|c|c|c|c|c|}
\hline & \multicolumn{3}{|c|}{$12 \mathrm{~F}-\mathrm{S}-33 \mathrm{~A}$} & \multicolumn{3}{|c|}{$12 \mathrm{~F}-\mathrm{S}-33 \mathrm{~B}$} & \multicolumn{3}{|c|}{$12 \mathrm{~F}-\mathrm{S}-34 \mathrm{~A}$} & \multicolumn{3}{|c|}{$12 \mathrm{~F}-\mathrm{S}-36 \mathrm{~A}$} \\
\hline Glass (kg) & \multicolumn{3}{|c|}{10300} & \multicolumn{3}{|c|}{10350} & \multicolumn{3}{|c|}{10450} & \multicolumn{3}{|c|}{10549} \\
\hline $\mathrm{PH}$ & \multicolumn{3}{|c|}{3.83} & \multicolumn{3}{|c|}{3.83} & \multicolumn{3}{|c|}{3.79} & \multicolumn{3}{|c|}{3.60} \\
\hline & Sus. & Dis.\# & Total & Sus. & Dis. & Total & Sus. & Dis. & Total & Sus. & Dis. & Total \\
\hline Total & 592 & 1576 & 2168 & 573 & 1640 & 2213 & 590 & 1528 & 2118 & 570 & 1580 & 2150 \\
\hline $\mathrm{Al}$ & 16.0 & 49.6 & 65.6 & 15.6 & 48.8 & 64.4 & 14.6 & 49.4 & 64.0 & 14.1 & 48.7 & 62.8 \\
\hline As & 0.8 & 0.9 & 1.7 & 0.7 & 0.9 & 1.6 & 0.8 & 0.9 & 1.7 & 0.8 & 1.0 & 1.7 \\
\hline $\mathrm{B}$ & 1.1 & 239.4 & 240.4 & 1.1 & 244.1 & 245.1 & 1.1 & 241.5 & 242.6 & 1.0 & 241.5 & 242.6 \\
\hline $\mathrm{Ba}$ & 0.3 & 0.2 & 0.5 & 0.3 & 0.2 & 0.5 & 0.3 & 0.2 & 0.5 & 0.3 & 0.2 & 0.5 \\
\hline $\mathrm{Ca}$ & 0.3 & 6.6 & 6.9 & 0.2 & 6.6 & 6.9 & 0.3 & 6.4 & 6.7 & 0.2 & 6.3 & 6.5 \\
\hline $\mathrm{Cd}$ & 1.5 & 6.0 & 7.5 & 1.5 & 6.0 & 7.5 & 1.4 & 5.8 & 7.2 & 1.4 & 5.9 & 7.2 \\
\hline $\mathrm{Cr}$ & 1.1 & 0.2 & 1.3 & 1.1 & 0.2 & 1.3 & 1.0 & 0.2 & 1.2 & 1.1 & 0.2 & 1.3 \\
\hline $\mathrm{Cs}$ & 1.2 & 7.3 & 8.5 & 1.1 & 7.2 & 8.3 & 1.4 & 6.8 & 8.2 & 1.0 & 6.8 & 7.8 \\
\hline $\mathrm{Cu}$ & 0.1 & 0.3 & 0.4 & 0.1 & 0.3 & 0.4 & 0.1 & 0.3 & 0.4 & 0.1 & 0.3 & 0.4 \\
\hline $\mathrm{Fe}$ & 106.9 & 0.1 & 107.0 & 104.0 & 0.1 & 104.1 & 106.0 & 0.1 & 106.1 & 106.0 & 0.1 & 106.1 \\
\hline $\mathrm{K}$ & 0.1 & 6.3 & 6.4 & 0.1 & 6.3 & 6.4 & 0.1 & 6.2 & 6.3 & 0.1 & 6.1 & 6.2 \\
\hline $\mathrm{Li}$ & 1.0 & 35.4 & 36.3 & 0.9 & 34.4 & 435.3 & 0.9 & 35.0 & 35.9 & 0.9 & 33.6 & 34.5 \\
\hline $\mathrm{Mg}$ & 0.2 & 1.5 & 1.6 & 0.2 & 1.5 & 1.7 & 0.2 & 1.5 & 1.6 & 0.2 & 1.4 & 1.6 \\
\hline $\mathrm{Mn}$ & 4.1 & 7.7 & 11.8 & 3.8 & 7.8 & 11.6 & 4.0 & 7.7 & 11.7 & 3.6 & 7.5 & 11.1 \\
\hline $\mathrm{Na}$ & 1.7 & 116.9 & 118.6 & 1.6 & 120.4 & 4122.0 & 1.7 & 117.6 & 119.3 & 1.6 & 117.6 & 119.2 \\
\hline $\mathrm{Ni}$ & 5.7 & 1.2 & 7.0 & 5.7 & 1.2 & 6.8 & 5.3 & 1.2 & 6.5 & 5.5 & 1.2 & 6.7 \\
\hline $\mathbb{P}$ & 0.7 & 1.1 & 1.8 & 0.8 & 0.9 & 1.7 & 0.8 & 1.0 & 1.8 & 0.6 & 1.0 & 1.6 \\
\hline $\mathrm{Pb}$ & 2.2 & 0.8 & 3.0 & 2.1 & 0.8 & 2.9 & 2.1 & 0.8 & 2.9 & 2.2 & 0.8 & 3.0 \\
\hline $\mathrm{Sb}$ & 1.6 & 0.3 & 2.0 & 1.6 & 0.3 & 2.0 & 1.0 & 0.3 & 1.3 & 1.6 & 0.3 & 1.9 \\
\hline $\mathrm{Se}$ & 39.2 & 245.1 & 284.3 & 38.7 & 272.9 & 311.6 & 39.3 & 264.9 & 304.2 & 38.8 & 279.8 & 318.6 \\
\hline $\mathrm{Si}$ & 94.2 & 24.6 & 118.8 & 90.1 & 24.4 & 114.5 & 92.8 & 24.3 & 117.1 & 74.5 & 24.4 & 98.9 \\
\hline $\mathrm{Sr}$ & 1.7 & 35.1 & 36.8 & 1.7 & 34.3 & 36.0 & 1.7 & 34.1 & 35.9 & 1.7 & 33.9 & 35.6 \\
\hline $\mathrm{Te}$ & 27.9 & 2.1 & 30.0 & 27.0 & 2.1 & 29.1 & 27.5 & 2.1 & 29.6 & 27.6 & 2.3 & 29.9 \\
\hline Ti & 0.4 & $<0.1$ & 0.4 & 0.4 & $<0.1$ & 0.4 & 0.3 & $<0.1$ & 0.3 & 0.3 & $<0.1$ & 0.3 \\
\hline $\mathrm{Zn}$ & 4.0 & 28.1 & 32.1 & 3.9 & 28.7 & 32.6 & 3.9 & 27.6 & 31.5 & 3.9 & 27.8 & 31.7 \\
\hline $\mathrm{Zr}$ & 10.1 & 0.8 & 10.9 & 9.8 & 0.7 & 10.5 & 9.5 & 0.9 & 10.3 & 8.5 & 1.1 & 9.6 \\
\hline $\mathrm{Cl}$ & NA & 78.8 & 78.8 & NA & 78.2 & 78.2 & $\mathrm{NA}$ & 73.7 & 73.7 & $\mathrm{NA}$ & 76.8 & 76.8 \\
\hline$F$ & $\mathrm{NA}$ & 105.5 & 105.5 & $\mathrm{NA}$ & 95.6 & 95.6 & NA & 93.97 & 94.0 & $\mathrm{NA}$ & 93.97 & 94.0 \\
\hline I & $<0.1$ & 127.8 & 127.8 & $<0.1$ & 128.9 & 128.9 & $<0.1$ & 130.6 & 130.6 & $<0.1$ & 112.0 & 112.0 \\
\hline Nitrate & NA & 44.7 & 44.7 & $\mathrm{NA}$ & 44.7 & 44.7 & NA & 42.8 & 42.8 & $\mathrm{NA}$ & 49.1 & 49.1 \\
\hline Nitrite & $\mathrm{NA}$ & $<0.1$ & $<0.1$ & $\mathrm{NA}$ & $<0.1$ & $<<0.1$ & NA & $<0.1$ & $<0.1$ & $\mathrm{NA}$ & $<0.1$ & $<0.1$ \\
\hline Sulfate & 1.9 & 429.87 & 431.8 & 0.2 & 387.51 & 387.7 & 0.6 & 388.69 & 389.3 & 0.9 & 394.71 & 395.6 \\
\hline
\end{tabular}


The Catholic University of America Vitreous State Laboratory
DuraMelter 1200 Start-Up Tests with AZ-101

Final Report, VSL-01R0100-2, Rev.0

Table 4.5. Calculated Speciation of DM1200 SBS Sample 12D-S-116A.

\begin{tabular}{|c|c|c|c|c|c|}
\hline Element & Species & Percent & Element & Species & Percent \\
\hline $\mathrm{Al}$ & $\begin{array}{l}\text { AlF2+ } \\
\text { AlF3(aq) } \\
\text { AlF+ }\end{array}$ & $\begin{array}{l}56.71 \\
39.05 \\
3.50\end{array}$ & $\mathrm{Li}$ & $\mathrm{Li}+$ & 99.66 \\
\hline As & HAsO3F- & 99.85 & $\mathrm{Mn}$ & $\begin{array}{l}\mathrm{Mn}+ \\
\mathrm{MnSeO4(aq)} \\
\text { MnSO4(aq) }\end{array}$ & \begin{tabular}{|l|}
70.57 \\
23.60 \\
5.19
\end{tabular} \\
\hline B & $\mathrm{B}(\mathrm{OH}) 3(\mathrm{aq})$ & 100.00 & $\mathrm{~N}$ & NO3- & 99.81 \\
\hline $\mathrm{Ba}$ & $\begin{array}{l}\mathrm{Ba}++ \\
\text { BaNO3+ }\end{array}$ & $\begin{array}{l}98.24 \\
1.70\end{array}$ & $\mathrm{Na}$ & $\mathrm{Na}+$ & 99.58 \\
\hline $\mathrm{Ca}$ & \begin{tabular}{|l}
$\mathrm{Ca}++$ \\
$\mathrm{CaSO} 4(\mathrm{aq})$ \\
$\mathrm{CaNO3+}$
\end{tabular} & \begin{tabular}{|l}
94.88 \\
4.00 \\
1.06
\end{tabular} & $\mathrm{Ni}$ & $\begin{array}{l}\mathrm{Ni}+ \\
\mathrm{NiSeO} 4(\mathrm{aq}) \\
\mathrm{NiSO} 4(\mathrm{aq})\end{array}$ & \begin{tabular}{|l|}
62.17 \\
34.86 \\
2.62
\end{tabular} \\
\hline $\mathrm{Cd}$ & $\mathrm{CdCl}+$ & 100.00 & $\mathrm{P}$ & $\begin{array}{l}\text { H2PO4- } \\
\text { FeHPO4+ } \\
\text { H3PO4(aq) }\end{array}$ & \begin{tabular}{|l|}
63.81 \\
24.74 \\
11.29 \\
\end{tabular} \\
\hline $\mathrm{Cl}$ & $\begin{array}{l}\mathrm{Cl}- \\
\mathrm{CdCl}+\end{array}$ & $\begin{array}{l}98.08 \\
1.53\end{array}$ & $\mathrm{~Pb}$ & $\begin{array}{l}\mathrm{Pb}++ \\
\mathrm{PbCl}+\end{array}$ & $\begin{array}{l}94.69 \\
5.23\end{array}$ \\
\hline $\mathrm{Cr}$ & HCrO4- & 99.88 & $\mathrm{~s}$ & $\begin{array}{l}\text { SO4- } \\
\text { HSO4- } \\
\text { SrSO4(aq) } \\
\text { NaSO4- } \\
\text { LiSO4- } \\
\text { CaSO4(aq) } \\
\text { MgSO4(aq) } \\
\end{array}$ & \begin{tabular}{|l}
86.59 \\
7.25 \\
1.80 \\
1.48 \\
1.09 \\
$6.700 \mathrm{E}-01$ \\
$5.153 \mathrm{E}-01$ \\
\end{tabular} \\
\hline $\mathrm{Cu}$ & $\mathrm{Cu}+$ & 99.31 & $\mathrm{Sb}$ & $\begin{array}{l}\mathrm{Sb}(\mathrm{OH}) 2 \mathrm{~F}(\mathrm{aq}) \\
\mathrm{Sb}(\mathrm{OH}) 3(\mathrm{aq}) \\
\mathrm{Sb}(\mathrm{OH}) 2+\end{array}$ & \begin{tabular}{|l|}
55.53 \\
42.34 \\
2.12
\end{tabular} \\
\hline $\mathrm{F}$ & $\begin{array}{l}\text { AlF2+ } \\
\text { AlF3(aq) } \\
\text { HF(aq) } \\
\text { F- } \\
\text { AlF+ } \\
\text { HAsO3F- } \\
\text { AlF4- }\end{array}$ & \begin{tabular}{|l}
45.20 \\
46.68 \\
2.77 \\
1.57 \\
1.40 \\
$3.115 \mathrm{E}-01$ \\
1.16 \\
\end{tabular} & $\mathrm{Se}$ & $\begin{array}{l}\mathrm{SeO} 4- \\
\mathrm{HSeO4-} \\
\mathrm{ZnSeO4(aq)}\end{array}$ & $\begin{array}{l}91.09 \\
6.44 \\
1.71\end{array}$ \\
\hline $\mathrm{Fe}$ & \begin{tabular}{|l}
$\mathrm{FeHPO} 4+$ \\
$\mathrm{FeOH}++$ \\
$\mathrm{Fe}+\mathrm{H}$ \\
$\mathrm{FeF}++$ \\
$\mathrm{Fe}(\mathrm{OH}) 2+$ \\
$\mathrm{FeF} 2+$
\end{tabular} & \begin{tabular}{|l|}
44.61 \\
29.95 \\
11.06 \\
5.63 \\
4.55 \\
3.74
\end{tabular} & $\mathrm{Si}$ & $\mathrm{SiO} 2(\mathrm{aq})$ & 100.00 \\
\hline I & IO3- & 99.63 & $\mathrm{Sr}$ & $\begin{array}{l}\text { Sr+t } \\
\text { SrSO4(aq) } \\
\text { SrNO3+ }\end{array}$ & \begin{tabular}{|l}
92.71 \\
5.90 \\
1.27 \\
\end{tabular} \\
\hline $\mathrm{K}$ & $\mathrm{K}+$ & 99.56 & $\mathrm{Zn}$ & $\begin{array}{l}\mathrm{Zn}++ \\
\mathrm{ZnSeO} 4(\mathrm{aq})\end{array}$ & \begin{tabular}{|l|}
83.57 \\
16.08
\end{tabular} \\
\hline $\mathrm{Mg}$ & $\begin{array}{l}\mathrm{Mg}+ \\
\mathrm{MgSO} 4(\mathrm{aq})\end{array}$ & $\begin{array}{l}91.71 \\
8.06\end{array}$ & $\mathrm{Zr}$ & $\begin{array}{l}\mathrm{Zr}(\mathrm{OH}) 4(\mathrm{aq}) \\
\mathrm{ZrF5}- \\
\mathrm{ZrF4}(\mathrm{aq}) \\
\text { ZrF6- } \\
\text { ZrF3+ }\end{array}$ & \begin{tabular}{|l}
60.60 \\
16.57 \\
9.58 \\
8.55 \\
3.81
\end{tabular} \\
\hline
\end{tabular}


The Catholic University of America Vitreous State Laboratory
DuraMelter 1200 Start-Up Tests with AZ-101

Final Report, VSL-01R0100-2, Rev.0

Table 4.6. Analytical Results for Samples of WESP Sump Fluids (mg/l).

\begin{tabular}{|c|c|c|c|c|c|c|c|c|c|c|c|c|}
\hline & \multicolumn{3}{|c|}{$12 \mathrm{D}-\mathrm{W}-96 \mathrm{~A}$} & \multicolumn{3}{|c|}{$12 \mathrm{E}-\mathrm{W}-60 \mathrm{~A}$} & \multicolumn{3}{|c|}{$12 \mathrm{E}-\mathrm{W}-118 \mathrm{~A}$} & \multicolumn{3}{|c|}{$12 \mathrm{~F}-\mathrm{W}-41 \mathrm{~A}$} \\
\hline Test & \multicolumn{3}{|c|}{ End of TO } & \multicolumn{3}{|c|}{ End of 1} & \multicolumn{3}{|c|}{ End of 2} & \multicolumn{3}{|c|}{ End of 3} \\
\hline \multirow[t]{2}{*}{$\mathrm{pH}$} & \multicolumn{3}{|c|}{2.76} & \multicolumn{3}{|c|}{2.52} & \multicolumn{3}{|c|}{2.31} & \multicolumn{3}{|c|}{2.31} \\
\hline & Sus.* & Dis.\# & Total & Sus. & Dis. & Total & Sus. & Dis. & Total & Sus. & Dis. & Total \\
\hline Total & 84 & 11990 & 12074 & 154 & 19178 & 19332 & 305 & 23528 & 23833 & 334 & 31836 & 32170 \\
\hline $\mathrm{Al}$ & $<0.1$ & 4.0 & 4.0 & 2.7 & 5.7 & 8.4 & 1.5 & 10.8 & 12.3 & 1.2 & 5.7 & 6.9 \\
\hline As & 0.1 & 14.5 & 14.6 & 0.2 & 26.4 & 26.6 & 0.2 & 38.3 & 38.5 & 0.2 & 26.4 & 26.6 \\
\hline $\mathrm{B}$ & 1.5 & 345.5 & 347.0 & 1.0 & 525.7 & 526.8 & \begin{tabular}{|l|}
0.4 \\
\end{tabular} & 665.8 & 666.2 & 0.5 & 525.7 & 526.2 \\
\hline $\mathrm{Ba}$ & 0.0 & 0.2 & 0.2 & 0.1 & 0.1 & 0.3 & $<0.1$ & 0.1 & 0.2 & $<0.1$ & 0.1 & 0.2 \\
\hline $\mathrm{Ca}$ & $<0.1$ & 23.1 & 23.1 & 1.5 & 27.5 & 29.0 & 0.6 & 32.2 & 32.8 & 0.5 & 27.5 & 28.0 \\
\hline $\mathrm{Cd}$ & 0.9 & 30.3 & 31.1 & 4.1 & 53.8 & 57.8 & 1.8 & 79.7 & 81.5 & 2.4 & 53.8 & 56.1 \\
\hline $\mathrm{Cr}$ & 7.1 & 11.4 & 18.5 & 32.3 & 17.8 & 50.1 & 15.1 & 23.4 & 38.5 & 17.7 & 17.8 & 35.5 \\
\hline $\mathrm{Cs}$ & 1.1 & 181.6 & 182.7 & 1.4 & 280.4 & 281.8 & 2.6 & 349.2 & 351.8 & 9.9 & 482.2 & 492.1 \\
\hline $\mathrm{Cu}$ & $<0.1$ & 1.1 & 1.1 & 0.2 & 2.1 & 2.2 & $<0.1$ & 3.0 & 3.0 & $<0.1$ & 2.1 & 2.1 \\
\hline $\mathrm{Fe}$ & 2.7 & 0.1 & 2.8 & 26.7 & 0.5 & 27.2 & 9.9 & 0.8 & 10.6 & 11.6 & 0.5 & 12.0 \\
\hline $\mathrm{K}$ & 1.2 & 364.4 & 365.6 & 5.4 & 542.8 & \begin{tabular}{|l}
548.2 \\
\end{tabular} & \begin{tabular}{|l|}
1.3 \\
\end{tabular} & 619.0 & 620.3 & 1.5 & 542.8 & 544.3 \\
\hline $\mathrm{Li}$ & 0.4 & 142.8 & 143.1 & 1.7 & 252.5 & 254.2 & \begin{tabular}{|l|}
0.2 \\
\end{tabular} & 351.3 & 351.5 & 0.1 & 252.5 & 252.6 \\
\hline $\mathrm{Mg}$ & 1.0 & 4.9 & 5.9 & 1.1 & 6.8 & 7.9 & 0.2 & 8.0 & 8.2 & 0.2 & 6.8 & 7.0 \\
\hline $\mathrm{Mn}$ & $<0.1$ & 0.5 & 0.5 & 0.2 & 1.0 & 1.2 & \begin{tabular}{|l|}
0.1 \\
\end{tabular} & 2.0 & 2.1 & \begin{tabular}{|l|l} 
\\
\end{tabular} & 1.0 & 1.1 \\
\hline $\mathrm{Na}$ & 3.2 & 1149.9 & 1153.2 & 14.8 & 1407.9 & 1422.7 & \begin{tabular}{|l|}
2.1 \\
\end{tabular} & 1722.9 & 1725.0 & 1.3 & 1407.9 & \begin{tabular}{|l}
1409.2 \\
\end{tabular} \\
\hline $\mathrm{Ni}$ & 0.1 & 3.8 & 3.9 & 1.8 & 7.0 & 8.8 & 0.5 & 10.8 & 11.3 & 0.5 & 7.0 & 7.5 \\
\hline $\mathrm{P}$ & 0.2 & 2.0 & 2.1 & 0.6 & 3.0 & 3.6 & \begin{tabular}{|l|}
0.2 \\
\end{tabular} & 3.6 & 3.8 & $<0.1$ & 3.0 & 3.1 \\
\hline $\mathrm{Pb}$ & 0.6 & 0.7 & 1.3 & 3.8 & 0.8 & 4.6 & 1.5 & 1.1 & 2.6 & 1.8 & 0.8 & 2.7 \\
\hline $\mathrm{Sb}$ & $<0.1$ & 1.3 & 1.3 & 0.2 & 1.8 & 2.1 & 0.6 & 3.3 & 3.9 & 0.8 & 1.8 & 2.6 \\
\hline $\mathrm{Se}$ & 28.1 & 4439.4 & 4467.5 & 146.3 & 6712.4 & 6858.6 & 44.3 & 8776.8 & 8821.1 & 68.3 & 6712.4 & 6780.7 \\
\hline $\mathrm{Si}$ & $<0.1$ & 8.0 & 8.0 & $<0.1$ & 11.5 & 11.5 & \begin{tabular}{|l|}
4.7 \\
\end{tabular} & 11.8 & 16.5 & 5.8 & 11.5 & 17.3 \\
\hline $\mathrm{Sr}$ & $<0.1$ & 5.0 & 5.1 & 0.1 & 7.8 & 8.0 & $<0.1$ & 7.5 & 7.5 & $<0.1$ & 7.8 & 7.9 \\
\hline $\mathrm{Te}$ & 6.2 & 169.2 & 175.4 & 41.5 & 261.6 & 303.2 & 20.1 & 321.2 & 341.3 & 31.0 & 261.6 & 292.6 \\
\hline $\mathrm{Ti}$ & 0.1 & $<0.1$ & 0.1 & 0.7 & 0.2 & 0.9 & \begin{tabular}{|l|}
0.3 \\
\end{tabular} & 0.3 & 0.6 & 0.3 & 0.2 & 0.5 \\
\hline $\mathrm{Zn}$ & 0.1 & 15.0 & 15.1 & 0.4 & 24.1 & 24.5 & \begin{tabular}{|l|}
0.1 \\
\end{tabular} & 33.5 & 33.6 & 0.1 & 24.1 & 24.2 \\
\hline $\mathrm{Zr}$ & $<0.0$ & 0.1 & 0.1 & 0.2 & 0.1 & 0.3 & \begin{tabular}{|l|}
0.1 \\
\end{tabular} & 0.1 & 0.2 & \begin{tabular}{|l} 
\\
0.1 \\
\end{tabular} & 0.1 & 0.2 \\
\hline $\mathrm{Cl}$ & $\mathrm{NA}$ & 656.6 & 656.6 & $\mathrm{NA}$ & 946.8 & 946.8 & NA & 1029.4 & 1029.4 & $\mathrm{NA}$ & 764 & 764.0 \\
\hline $\mathrm{F}$ & NA & 26.2 & 26.2 & NA & 48.4 & 48.4 & NA & 53.7 & 53.7 & NA & 61.5 & 61.5 \\
\hline $\mathrm{I}$ & $<0.1$ & 2.0 & 2.0 & $<0.1$ & 1.6 & 1.6 & $<0.1$ & 1.7 & 1.7 & $<0.1$ & 1.9 & 1.9 \\
\hline Nitrate & $\mathrm{NA}$ & 490.6 & 490.6 & $\mathrm{NA}$ & 716.2 & 716.2 & NA & 811.3 & 811.3 & $\mathrm{NA}$ & 1273.3 & \begin{tabular}{|l|}
1273.3 \\
\end{tabular} \\
\hline Nitrite & $\mathrm{NA}$ & $<0.1$ & $<0.1$ & $\mathrm{NA}$ & $<0.1$ & $<0.1$ & NA & $<0.1$ & $<0.1$ & NA & $<0.1$ & $<0.1$ \\
\hline Sulfate & 6.9 & 2221.3 & 2228.2 & 20.7 & 3317.3 & 3338.0 & 1.7 & 4242.3 & 4244.0 & 1.7 & 4954.4 & 4956.1 \\
\hline
\end{tabular}


The Catholic University of America Vitreous State Laboratory
DuraMelter 1200 Start-Up Tests with AZ-101

Final Report, VSL-01R0100-2, Rev.0

Table 5.1. DM1200 Glass Discharge Samples and Analyses Performed.

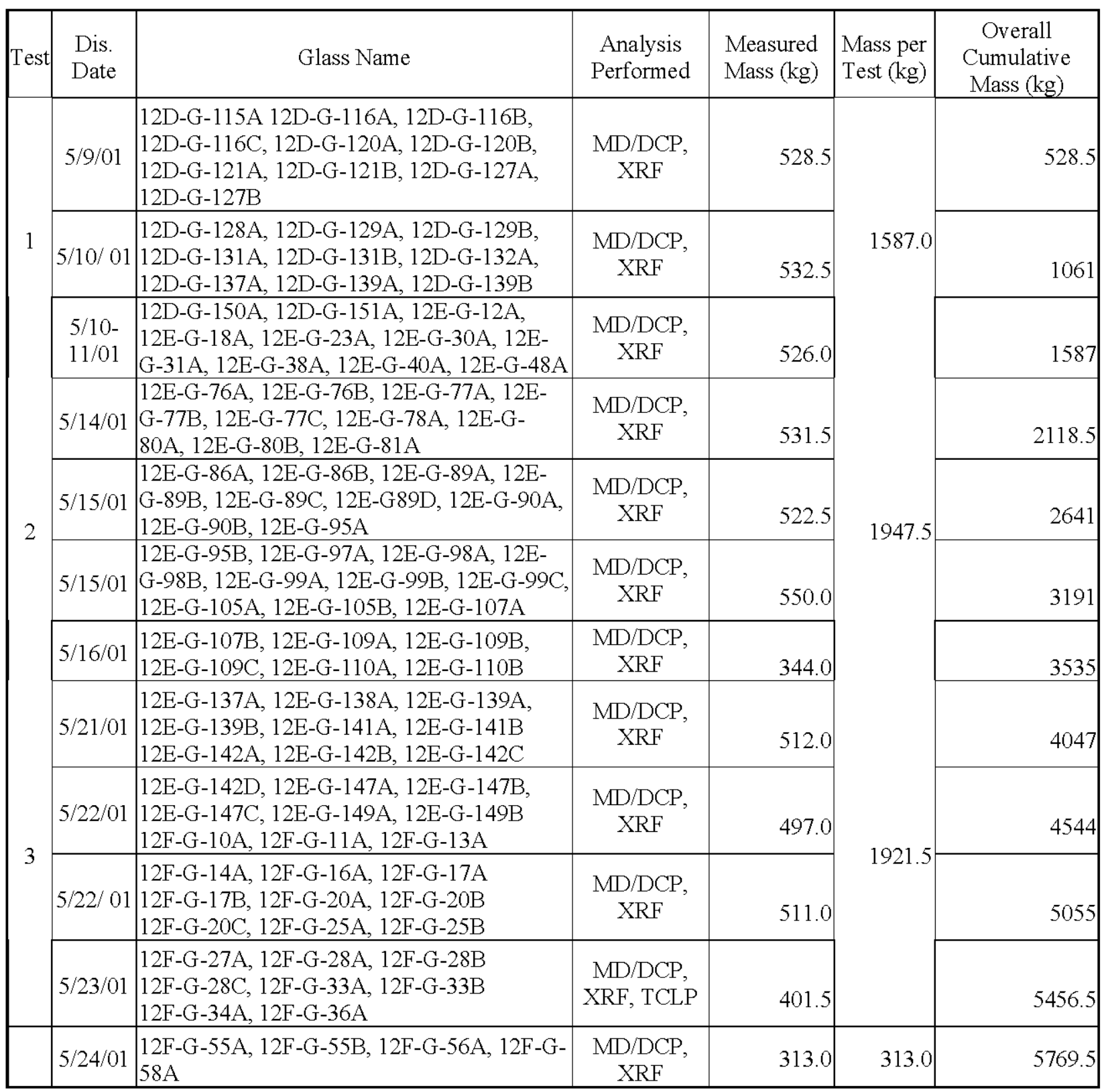


The Catholic University of America Vitreous State Laboratory
DuraMelter 1200 Start-Up Tests with AZ-101

Final Report, VSL-01R0100-2, Rev.0

Table 5.2. Chemical Compositions of Glass Samples Discharged during DM1200 Commissioning tests (wt\%).

\begin{tabular}{|c|c|c|c|c|c|c|c|c|c|c|c|c|c|}
\hline Test \# & & \multicolumn{6}{|c|}{1} & \multicolumn{6}{|c|}{2} \\
\hline Sample & \multirow[t]{3}{*}{ Target } & \multicolumn{2}{|c|}{ 12D-G-127B } & \multicolumn{2}{|c|}{ 12D-G-139B } & \multicolumn{2}{|c|}{$12 \mathrm{E}-\mathrm{G}-48 \mathrm{~A}$} & \multicolumn{2}{|c|}{ 12E-G-81A } & \multicolumn{2}{|c|}{ 12E-G-95A } & \multicolumn{2}{|c|}{$12 \mathrm{E}-\mathrm{G}-107 \mathrm{~A}$} \\
\hline Cumulative & & 528 & & 106 & & 15 & & \multicolumn{2}{|c|}{2118.5} & \multicolumn{2}{|c|}{2641} & \multicolumn{2}{|c|}{3191} \\
\hline & & $\mathrm{XRF}$ & $\mathrm{DCP}$ & $\mathrm{XRF}$ & $\mathrm{DCP}$ & XRF & $\overline{\mathrm{DCP}}$ & $\mathrm{XRF}$ & DCP & XRF & DCP & XRF & $\overline{\mathrm{DCP}}$ \\
\hline $\mathrm{Al} 2 \mathrm{O} 3$ & 7.40 & 8.07 & 7.85 & 7.88 & 7.64 & 7.90 & 7.39 & 7.71 & 7.39 & 7.75 & 7.42 & 7.54 & 7.24 \\
\hline $\mathrm{As} 2 \mathrm{O} 3$ & 0.04 & 0.04 & 0.05 & 0.04 & 0.04 & 0.04 & 0.02 & 0.04 & 0.04 & 0.04 & 0.01 & 0.04 & 0.04 \\
\hline $\mathrm{B} 2 \mathrm{O} 3$ & 10.00 & 10.47 & 10.47 & 10.38 & 10.38 & 10.43 & 10.43 & 10.46 & 10.46 & 10.68 & 10.68 & 10.70 & 10.70 \\
\hline $\mathrm{BaO}$ & 0.04 & NA & 0.06 & NA & 0.06 & $\mathrm{NA}$ & 0.06 & NA & 0.06 & NA & 0.06 & $\mathrm{NA}$ & 0.06 \\
\hline $\mathrm{CaO}$ & 0.25 & 0.41 & 0.42 & 0.40 & 0.42 & 0.39 & 0.41 & 0.39 & 0.40 & 0.39 & 0.41 & 0.42 & 0.43 \\
\hline $\mathrm{CdO}$ & 0.37 & 0.39 & 0.31 & 0.41 & 0.32 & 0.44 & 0.33 & 0.42 & 0.34 & 0.44 & 0.34 & 0.43 & 0.33 \\
\hline $\mathrm{CeO} 2$ & 0.08 & 0.07 & NA & 0.07 & NA & 0.07 & NA & 0.08 & NA & 0.06 & $\mathrm{NA}$ & 0.09 & $\mathrm{NA}$ \\
\hline $\mathrm{Cl}$ & 0.01 & NA & $\mathrm{NA}$ & $\mathrm{NA}$ & $\mathrm{NA}$ & NA & $\mathrm{NA}$ & NA & $\mathrm{NA}$ & NA & $\mathrm{NA}$ & $\mathrm{NA}$ & $\mathrm{NA}$ \\
\hline $\mathrm{Cr} 2 \mathrm{O} 3$ & 0.04 & 0.07 & 0.06 & 0.06 & 0.06 & 0.04 & 0.05 & 0.04 & 0.04 & 0.04 & 0.03 & 0.03 & 0.03 \\
\hline $\mathrm{Cs} 2 \mathrm{O}$ & 0.08 & 0.08 & 0.08 & 0.09 & 0.09 & 0.10 & 0.08 & 0.09 & 0.08 & 0.10 & 0.08 & 0.10 & 0.09 \\
\hline $\mathrm{CuO}$ & 0.03 & 0.03 & 0.03 & 0.04 & 0.03 & 0.03 & 0.03 & 0.04 & 0.03 & 0.03 & 0.03 & 0.03 & 0.03 \\
\hline 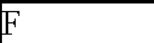 & 0.04 & NA & NA & NA & NA & NA & NA & NA & $\mathrm{NA}$ & NA & NA & NA & $\mathrm{NA}$ \\
\hline $\mathrm{Fe} 2 \mathrm{O} 3$ & 10.39 & 10.47 & 8.58 & 10.52 & 8.90 & 10.10 & 8.63 & 10.41 & 8.85 & 10.35 & 8.73 & 10.66 & 10.34 \\
\hline $\mathrm{K} 2 \mathrm{O}$ & 0.17 & 0.34 & 0.28 & 0.31 & 0.26 & 0.30 & 0.26 & 0.29 & 0.24 & 0.28 & 0.25 & 0.27 & 0.23 \\
\hline $\mathrm{La} 2 \mathrm{O} 3$ & 0.32 & 0.24 & $\mathrm{NA}$ & 0.20 & $\mathrm{NA}$ & 0.18 & $\mathrm{NA}$ & 0.18 & $\mathrm{NA}$ & 0.17 & $\mathrm{NA}$ & 0.18 & $\mathrm{NA}$ \\
\hline $\mathrm{Li} 2 \mathrm{O}$ & 6.00 & 5.13 & 5.13 & 5.12 & 5.12 & 5.08 & 5.08 & 5.22 & 5.22 & 5.29 & 5.29 & 5.18 & $\begin{array}{ll}5.18 \\
\end{array}$ \\
\hline $\mathrm{MgO}$ & 0.06 & NA & 0.23 & NA & 0.20 & NA & 0.18 & NA. & 0.16 & NA & 0.15 & NA & 0.14 \\
\hline $\mathrm{MnO}$ & 3.03 & 3.17 & 2.62 & 3.20 & 2.64 & 3.13 & 2.74 & 3.22 & 2.73 & 3.20 & 2.79 & 3.27 & 2.79 \\
\hline $\mathrm{Na} 2 \mathrm{O}$ & 6.59 & 7.18 & 6.65 & 7.30 & 6.52 & 7.81 & 6.39 & 7.16 & 6.61 & 7.08 & 6.48 & 6.93 & 6.49 \\
\hline $\mathrm{NiO}$ & 0.54 & 0.51 & 0.48 & 0.52 & 0.48 & 0.50 & 0.49 & 0.51 & 0.50 & 0.51 & 0.52 & 0.53 & 0.51 \\
\hline $\mathrm{P} 2 \mathrm{O} 5$ & 0.13 & 0.34 & 0.42 & 0.31 & 0.36 & 0.25 & 0.36 & 0.24 & 0.31 & 0.21 & 0.25 & 0.19 & 0.27 \\
\hline $\mathrm{PbO}$ & 0.15 & 0.14 & 0.18 & 0.14 & 0.19 & 0.13 & 0.20 & 0.14 & 0.20 & 0.13 & 0.19 & 0.13 & 0.19 \\
\hline $\mathrm{Sb} 2 \mathrm{O} 3$ & 0.21 & 0.17 & 0.24 & 0.19 & 0.22 & 0.21 & 0.31 & 0.19 & 0.29 & 0.20 & 0.22 & 0.20 & 0.21 \\
\hline $\mathrm{SeO} 2$ & 0.15 & 0.03 & 0.00 & 0.04 & 0.03 & 0.06 & 0.03 & 0.04 & 0.03 & 0.04 & 0.04 & 0.04 & 0.01 \\
\hline $\mathrm{SiO} 2$ & 45.53 & 45.12 & 41.19 & 45.06 & 41.45 & 45.25 & 41.95 & 45.15 & 41.50 & 45.37 & 41.52 & 44.97 & 40.66 \\
\hline $\mathrm{SO} 3$ & 0.25 & 0.15 & $\mathrm{NA}$ & 0.17 & $\mathrm{NA}$ & 0.21 & $\mathrm{NA}$ & 0.20 & $\mathrm{NA}$ & 0.21 & $\mathrm{NA}$ & 0.23 & $\mathrm{NA}$ \\
\hline $\mathrm{SrO}$ & 2.32 & 2.14 & 1.94 & 2.17 & 1.95 & 2.10 & 1.95 & 2.16 & 1.96 & 2.13 & 1.97 & 2.21 & 1.96 \\
\hline $\mathrm{TeO} 2$ & 0.14 & 0.11 & 0.13 & 0.13 & 0.12 & 0.16 & 0.13 & 0.13 & 0.14 & 0.15 & 0.15 & 0.14 & 0.15 \\
\hline $\mathrm{TiO} 2$ & 0.06 & 0.08 & 0.09 & 0.07 & 0.09 & 0.07 & 0.10 & 0.07 & 0.09 & 0.07 & 0.10 & 0.07 & 0.11 \\
\hline $\mathrm{ZnO}$ & 2.00 & 2.04 & 1.96 & 2.03 & 1.95 & 1.92 & 1.94 & 1.98 & 1.93 & 1.96 & 1.90 & 2.03 & 1.88 \\
\hline $\mathrm{ZrO} 2$ & 3.56 & 3.87 & 3.46 & 3.99 & 3.54 & 3.96 & 3.56 & 4.03 & 3.59 & 4.00 & 3.62 & 4.18 & 3.66 \\
\hline Sum & 100.00 & 100.87 & 92.86 & 100.84 & 92.98 & 100.87 & 93.03 & 100.58 & 93.10 & 100.86 & 93.19 & 100.80 & 93.64 \\
\hline
\end{tabular}

Target: HLW98-31; NA: Not analyzed. The Cs2O contents in the DCP column were obtained by atomic absorption spectroscopy analysis. 
The Catholic University of America Vitreous State Laboratory
DuraMelter 1200 Start-Up Tests with AZ-101

Final Report, VSL-01R0100-2, Rev.0

\section{Table 5.2. Chemical Compositions of Glass Samples Discharged during DM1200} Commissioning Tests (wt \%) (continued).

\begin{tabular}{|c|c|c|c|c|c|c|c|c|c|c|}
\hline Test \# & & \multicolumn{2}{|c|}{2} & \multicolumn{5}{|c|}{3} & \multirow{2}{*}{\multicolumn{2}{|c|}{$12 \mathrm{~F}-\mathrm{G}-58 \mathrm{~A}$}} \\
\hline Sample & Target & $12 \mathrm{E}-\mathrm{G}$ & $110 \mathrm{~B}$ & $12 \mathrm{~F}-\mathrm{G}$ & $3 \mathrm{~A}$ & $12 \mathrm{~F}-\mathrm{G}-25 \mathrm{~B}$ & $12 \mathrm{~F}-\mathrm{G}$ & & & \\
\hline \begin{tabular}{|c|}
$\begin{array}{c}\text { Cumulative } \\
\mathrm{kg}\end{array}$ \\
\end{tabular} & & 35 & & 454 & & 5055 & 5456 & & 5769 & \\
\hline Method & & $\mathrm{XRF}$ & $\overline{\mathrm{DCP}}$ & XRF & $\overline{\mathrm{DCP}}$ & XRF & XRF & DCP & XRF & $\overrightarrow{\mathrm{DCP}}$ \\
\hline $\mathrm{Al} 2 \mathrm{O} 3$ & 7.40 & 7.55 & 7.22 & 7.71 & 7.52 & 7.68 & \begin{tabular}{l|l|}
7.59 \\
\end{tabular} & 7.85 & 7.78 & 7.63 \\
\hline $\mathrm{s} 2 \mathrm{O} 3$ & 0.04 & 0.04 & 0.01 & 0.04 & 0.02 & 0.04 & 0.04 & 0.03 & 0.04 & 0.03 \\
\hline $\mathrm{B} 2 \mathrm{O} 3$ & 10.00 & 10.69 & 10.69 & 11.05 & 11.05 & 11.19 & 11.51 & 11.51 & 10.92 & 10.92 \\
\hline $\mathrm{BaO}$ & 0.04 & $\mathrm{NA}$ & 0.06 & NA & 0.06 & $\mathrm{NA}$ & $\mathrm{NA}$ & 0.06 & NA & 0.06 \\
\hline $\mathrm{aO}$ & 0.25 & 0.37 & 0.40 & 0.38 & 0.38 & 0.39 & 0.39 & 0.39 & 0.40 & 0.39 \\
\hline $\mathrm{dO}$ & 0.37 & 0.45 & 0.33 & 0.43 & 0.33 & 0.44 & 0.44 & 0.38 & 0.47 & 0.37 \\
\hline $\mathrm{CeO} 2$ & 0.08 & 0.08 & $\mathrm{NA}$ & 0.07 & $\mathrm{NA}$ & 0.08 & 0.08 & NA & 0.08 & $\mathrm{NA}$ \\
\hline $\mathrm{Cl}$ & 0.01 & $\mathrm{NA}$ & $\mathrm{NA}$ & NA & $\mathrm{NA}$ & NA & $\mathrm{NA}$ & NA & NA & $\mathrm{NA}$ \\
\hline $\mathrm{Cr} 2 \mathrm{O} 3$ & 0.04 & 0.03 & 0.03 & 0.04 & 0.04 & 0.05 & 0.05 & 0.04 & 0.05 & 0.04 \\
\hline $\mathrm{Cs} 2 \mathrm{O}$ & 0.08 & 0.12 & 0.08 & 0.08 & 0.08 & 0.08 & 0.08 & 0.10 & 0.09 & 0.10 \\
\hline $\mathrm{CuO}$ & 0.03 & 0.04 & 0.03 & 0.04 & 0.03 & 0.04 & 0.04 & 0.04 & 0.03 & 0.03 \\
\hline 4 & 0.04 & $\mathrm{NA}$ & $\mathrm{NA}$ & NA & $\mathrm{NA}$ & NA & NA & NA & NA & $\mathrm{NA}$ \\
\hline $\mathrm{Fe} 2 \mathrm{O} 3$ & 10.39 & 10.52 & 9.12 & 10.48 & 9.36 & 10.39 & 10.33 & 9.09 & 10.19 & 9.0 \\
\hline $\mathrm{K} 2 \mathrm{O}$ & 0.17 & 0.26 & 0.23 & 0.27 & 0.22 & 0.27 & 0.26 & 0.23 & 0.27 & 0.24 \\
\hline $\mathrm{La} 2 \mathrm{O} 3$ & 0.32 & 0.18 & NA & 0.18 & $\mathrm{NA}$ & 0.18 & 0.18 & NA & \begin{tabular}{|l|}
0.18 \\
\end{tabular} & $\mathrm{NA}$ \\
\hline $\mathrm{Li} 2 \mathrm{O}$ & 6.00 & 5.20 & 5.20 & 5.29 & 5.29 & 5.19 & 5.34 & 5.34 & 5.16 & 5.16 \\
\hline $\mathrm{MgO}$ & 0.06 & $\mathrm{NA}$ & 0.13 & NA & 0.11 & NA & $\mathrm{NA}$ & 0.11 & NA & 0.11 \\
\hline $\mathrm{MnO}$ & 3.03 & 3.27 & 2.78 & 3.33 & 2.81 & 3.35 & 3.37 & 2.93 & 3.27 & 2.75 \\
\hline $\mathrm{Na} 2 \mathrm{O}$ & 6.59 & 7.14 & 6.44 & 6.92 & 6.65 & 7.12 & 7.18 & 6.78 & 6.52 & 6.68 \\
\hline $\mathrm{NiO}$ & 0.54 & 0.53 & 0.52 & 0.54 & 0.49 & 0.54 & 0.54 & 0.51 & 0.53 & 0.5 \\
\hline $\mathrm{P} 2 \mathrm{O} 5$ & 0.13 & 0.19 & 0.26 & 0.19 & 0.26 & 0.18 & 0.18 & 0.32 & 0.18 & 0.3 \\
\hline $\mathrm{PbO}$ & 0.15 & 0.13 & 0.20 & 0.14 & 0.20 & 0.15 & 0.14 & 0.19 & 0.14 & 0.2 \\
\hline $\mathrm{Sb} 2 \mathrm{O} 3$ & 0.21 & 0.22 & 0.26 & 0.18 & 0.21 & 0.18 & 0.17 & 0.16 & 0.20 & 0.1 \\
\hline $\mathrm{SeO} 2$ & 0.15 & 0.04 & 0.07 & 0.03 & 0.01 & 0.03 & 0.03 & 0.02 & 0.03 & 0.01 \\
\hline $\mathrm{SiO} 2$ & 45.53 & 45.03 & 41.07 & 44.90 & 43.84 & 44.93 & 44.94 & 43.97 & 45.57 & 43.31 \\
\hline $\mathrm{SO} 3$ & 0.25 & 0.22 & $\mathrm{NA}$ & 0.20 & NA & 0.19 & 0.20 & NA & 0.20 & $\mathrm{NA}$ \\
\hline $\mathrm{SrO}$ & 2.32 & 2.19 & 1.96 & 2.28 & 2.04 & 2.25 & 2.25 & 2.10 & 2.24 & 2.04 \\
\hline $\mathrm{TeO} 2$ & 0.14 & 0.16 & 0.16 & 0.13 & 0.11 & 0.12 & 0.12 & 0.15 & 0.14 & 0.12 \\
\hline TiO2 & 0.06 & 0.06 & 0.10 & 0.07 & 0.09 & 0.07 & 0.07 & 0.10 & 0.07 & 0.1 \\
\hline $\mathrm{ZnO}$ & 2.00 & 1.98 & 1.90 & 2.01 & 1.88 & 2.03 & 2.03 & 1.85 & 1.98 & 1.8 \\
\hline $\mathrm{ZrO} 2$ & 3.56 & 4.17 & 3.61 & 4.26 & 3.66 & 4.21 & 4.19 & 3.78 & 4.24 & 3.5 \\
\hline Sum & 100.00 & 100.83 & 92.76 & 101.26 & 96.67 & 101.35 & 101.72 & 97.91 & 100.97 & 95.7 \\
\hline
\end{tabular}

Target: HLW98-31; NA: Not analyzed. The Cs2O contents in the DCP column were obtained by atomic absorption spectroscopy analysis. 
The Catholic University of America

Vitreous State Laboratory
DuraMelter 1200 Start-Up Tests with AZ-101

Final Report, VSL-01R0100-2, Rev.0

Table 5.3. TCLP Leachate Concentrations for DM1200 Commissioning Test Glass Product. $(\mathrm{mg} / 1)$

\begin{tabular}{|l|c|c|c|c|c|c|c|c|c|c|}
\hline \multicolumn{1}{|c|}{ Sample ID } & $\mathrm{Ag}$ & $\mathrm{As}$ & $\mathrm{Ba}$ & $\mathrm{Cd}$ & $\mathrm{Cr}$ & $\mathrm{Cu}$ & $\mathrm{Ni}$ & $\mathrm{Pb}$ & $\mathrm{Se}$ & $\mathrm{Zn}$ \\
\hline UTS Limit & 0.140 & 5.000 & 21.000 & 0.110 & 0.600 & & 11.000 & 0.750 & 5.700 & 4.300 \\
\hline 12F-G-36A & $<0.003$ & $<0.049$ & 0.584 & 0.072 & $<0.006$ & 0.051 & 0.071 & 0.032 & $<0.053$ & 0.522 \\
\hline $\begin{array}{l}\text { Detection } \\
\text { Limit }\end{array}$ & 0.003 & 0.049 & 0.002 & 0.003 & 0.006 & 0.001 & 0.008 & 0.024 & 0.053 & 0.003 \\
\hline
\end{tabular}


Table 6.1. Particulate and Gaseous Emissions Sampling Results During Test 1.

\begin{tabular}{|c|c|c|c|c|c|c|c|c|c|c|c|}
\hline & & \multirow{3}{*}{$\begin{array}{l}\text { Feed } \\
\text { Flux } \\
(\mathrm{g} / \mathrm{hr})\end{array}$} & \multicolumn{6}{|c|}{ Melter Emissions } & \multicolumn{3}{|c|}{ SBS } \\
\hline & & & \multicolumn{3}{|c|}{ Run 1} & \multicolumn{3}{|c|}{ Run 2} & \multirow[b]{2}{*}{$\mathrm{mg} / \mathrm{min}$} & \multirow[b]{2}{*}{$\begin{array}{l}\% \text { of } \\
\text { Feed }\end{array}$} & \multirow{2}{*}{$\begin{array}{c}\text { DF across } \\
\text { SBS }\end{array}$} \\
\hline & & & $\mathrm{mg} / \mathrm{min}$ & $\begin{array}{l}\% \text { of } \\
\text { Feed }\end{array}$ & DF & $\mathrm{mg} / \mathrm{min}$ & $\begin{array}{l}\% \text { of } \\
\text { Feed }\end{array}$ & DF & & & \\
\hline & Total $^{\$}$ & 9655 & 78.0 & 0.05 & 2063 & 60.0 & 0.04 & 2682 & 37.8 & 0.02 & 2.1 \\
\hline \multirow{28}{*}{ 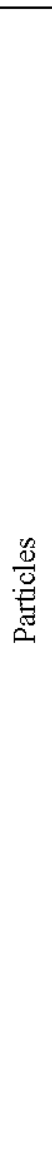 } & $\mathrm{Al}$ & 303.6 & 1.7 & 0.03 & 2976 & 1.8 & 0.03 & 2811 & 0.2 & $<0.01$ & 10.0 \\
\hline & As & 2.4 & 0.1 & 0.32 & 400 & 0.1 & 0.25 & 400 & $<0.1$ & 0.08 & 3.8 \\
\hline & $\mathrm{B}$ & 120.3 & 0.8 & 0.04 & 2506 & 2.1 & 0.10 & 955 & 0.1 & $<0.01$ & 22.1 \\
\hline & $\mathrm{Ba}$ & 2.8 & $<0.1$ & 0.02 & $>470$ & $<0.1$ & 0.04 & $>470$ & $<0.1$ & $<0.01$ & $\mathrm{NC}$ \\
\hline & $\mathrm{Ca}$ & 13.9 & 0.9 & 0.38 & 257 & 1.0 & 0.43 & 232 & 0.5 & 0.21 & 1.9 \\
\hline & $\mathrm{Cd}$ & 25.7 & 0.1 & 0.03 & 4283 & 0.3 & 0.07 & 1428 & $<0.1$ & $<0.01$ & 21.8 \\
\hline & $\mathrm{Cr}$ & 1.1 & $<0.1$ & 0.08 & $>180$ & 0.1 & 0.51 & 183 & $<0.1$ & 0.02 & 13.0 \\
\hline & Cs & 6.2 & 0.1 & 0.09 & 1033 & 0.4 & 0.39 & 258 & $<0.1$ & $<0.01$ & $\mathrm{NC}$ \\
\hline & $\mathrm{Cu}$ & 1.9 & $<0.1$ & 0.02 & $>320$ & $<0.1$ & 0.11 & $>320$ & $<0.1$ & 0.09 & 0.7 \\
\hline & $\mathrm{Fe}$ & 563.1 & 4.0 & 0.04 & 2346 & 4.2 & 0.05 & 2235 & 0.5 & 0.01 & 7.6 \\
\hline & I & 7.8 & $<0.1$ & $<0.01$ & $>1300$ & $<0.1$ & $<0.01$ & $>1300$ & $<0.1$ & $<0.01$ & $\mathrm{NC}$ \\
\hline & $\mathrm{K}$ & 10.9 & 0.3 & 0.15 & 606 & 0.4 & 0.22 & 454 & 0.1 & 0.04 & 4.9 \\
\hline & $\mathrm{Li}$ & 216.0 & 0.6 & 0.02 & 6000 & 1.2 & 0.03 & 3000 & $<0.1$ & $<0.01$ & 56.4 \\
\hline & $\mathrm{Mg}$ & 2.8 & 0.2 & 0.45 & 233 & 0.1 & 0.32 & 467 & 0.1 & 0.19 & 2.0 \\
\hline & $\mathrm{Mn}$ & 181.9 & 0.3 & 0.01 & 10106 & 0.4 & 0.01 & 7579 & $<0.1$ & $<0.01$ & 14.4 \\
\hline & $\mathrm{Na}$ & 378.9 & 4.4 & 0.07 & 1435 & 6.2 & 0.10 & 1019 & 0.5 & 0.01 & 10.0 \\
\hline & $\mathrm{Ni}$ & 32.9 & 0.2 & 0.03 & 2742 & 0.3 & 0.06 & 1828 & $<0.1$ & $<0.01$ & $\mathrm{NC}$ \\
\hline & $\mathrm{P}$ & 113.7 & 0.1 & 0.01 & 18950 & $<0.1$ & $<0.01$ & $>18950$ & $<0.1$ & $<0.01$ & $\overline{8.4}$ \\
\hline & $\mathrm{Pb}$ & 10.8 & 0.1 & 0.06 & 1800 & 0.1 & 0.07 & 1800 & $<0.1$ & 0.01 & 5.5 \\
\hline & $\mathrm{S}$ & 7.8 & 2.6 & 2.00 & 50 & 1.8 & 1.42 & 72 & 0.7 & 0.55 & 3.1 \\
\hline & $\mathrm{Sb}$ & 12.3 & 0.1 & 0.03 & 2050 & $<0.1$ & $<0.01$ & $>2050$ & $<0.1$ & 0.01 & 2.6 \\
\hline & $\mathrm{Se}$ & 8.3 & 8.3 & 6.03 & 17 & 21.2 & 15.37 & 7 & 0.4 & 0.31 & 34.0 \\
\hline & $\mathrm{Si}$ & 1649.5 & 5.1 & 0.02 & 5391 & 2.2 & 0.01 & 12496 & 1.1 & $<0.01$ & 3.3 \\
\hline & $\mathrm{Sr}$ & 152.0 & 0.8 & 0.03 & 3167 & 1.2 & 0.05 & 2111 & $<0.1$ & $<0.01$ & $\mathrm{NC}$ \\
\hline & $\mathrm{Te}$ & 8.7 & 0.5 & 0.33 & 290 & 1.9 & 1.31 & 76 & 0.1 & 0.10 & 8.6 \\
\hline & $\mathrm{Ti}$ & 2.8 & $<0.1$ & 0.10 & $>470$ & 0.1 & 0.13 & 467 & $<0.1$ & 0.04 & 2.6 \\
\hline & $\mathrm{Zn}$ & 124.5 & 0.8 & 0.04 & 2594 & 1.3 & 0.06 & 1596 & $<0.1$ & $<0.01$ & 36.0 \\
\hline & $\mathrm{Zr}$ & 204.3 & 0.3 & 0.01 & 11350 & 0.1 & $<0.01$ & 34050 & $<0.1$ & $<0.01$ & $\mathrm{NC}$ \\
\hline \multirow{6}{*}{ है } & $\mathrm{B}$ & 120.3 & 17.2 & 0.86 & 117 & 4.9 & 0.24 & 409 & 0.7 & 0.03 & 15.8 \\
\hline & $\mathrm{Cl}$ & 0.8 & 8.7 & 67.60 & 2 & 2.9 & 22.69 & 5 & $<0.1$ & $<0.01$ & $\mathrm{NC}$ \\
\hline & $\mathrm{F}$ & 3.1 & 4.4 & 8.47 & 12 & 4.3 & 8.23 & 12 & $<0.1$ & $<0.01$ & $\mathrm{NC}$ \\
\hline & I & 7.8 & 47.2 & 36.51 & 3 & 122.3 & 94.67 & 1 & 93.0 & 72.02 & 1.8 \\
\hline & $\mathrm{S}$ & 7.8 & 5.2 & 4.01 & 25 & 1.8 & 1.36 & 72 & $<0.1$ & $<0.01$ & $\mathrm{NC}$ \\
\hline & $\mathrm{Se}$ & 8.3 & 17.4 & 12.65 & 8 & 12.7 & 9.24 & 11 & 0.3 & 0.20 & 50.2 \\
\hline
\end{tabular}


Table 6.2. Particulate and Gaseous Melter Emissions Sampling Results from Early During Commissioning Test 2.

\begin{tabular}{|c|c|c|c|c|c|}
\hline & \multirow{3}{*}{$\begin{array}{l}\text { Feed } \\
\text { Flux } \\
(\mathrm{g} / \mathrm{hr})\end{array}$} & \multicolumn{3}{|c|}{ Melter Emissions } \\
\hline & & & \multicolumn{3}{|c|}{ Run 1} \\
\hline & & & $\mathrm{mg} / \mathrm{min}$ & $\begin{array}{l}\% \% \text { of } \\
\text { Feed }\end{array}$ & DF \\
\hline & Total & 42045 & 1879 & 0.27 & 373 \\
\hline \multirow{28}{*}{ 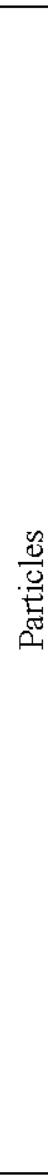 } & $\mathrm{Al}$ & 1322.2 & 40.3 & 0.18 & 547 \\
\hline & As & 10.2 & 1.7 & 1.02 & 100 \\
\hline & $\mathrm{B}$ & 523.7 & 32.7 & 0.37 & 267 \\
\hline & $\mathrm{Ba}$ & 12.1 & 0.5 & 0.24 & 403 \\
\hline & $\mathrm{Ca}$ & 60.3 & 5.4 & 0.54 & 186 \\
\hline & $\mathrm{Cd}$ & 111.8 & 6.3 & 0.34 & 296 \\
\hline & $\mathrm{Cr}$ & 4.6 & 1.0 & 1.33 & 77 \\
\hline & $\mathrm{Cs}$ & 27.0 & 9.5 & 2.10 & 47 \\
\hline & $\mathrm{Cu}$ & 8.1 & 0.4 & 0.29 & 338 \\
\hline & $\mathrm{Fe}$ & 2452.0 & 97.7 & 0.24 & 418 \\
\hline & $\mathrm{I}$ & 33.8 & $<0.1$ & $<0.01$ & $>5630$ \\
\hline & $\mathrm{K}$ & 47.6 & 7.3 & 0.92 & 109 \\
\hline & $\mathrm{Li}$ & 940.7 & 21.7 & 0.14 & 723 \\
\hline & $\mathrm{Mg}$ & 12.2 & 0.9 & 0.45 & 226 \\
\hline & $\mathrm{Mn}$ & 792.0 & 8.2 & 0.06 & 1610 \\
\hline & $\mathrm{Na}$ & 1650.2 & 91.4 & 0.33 & 301 \\
\hline & $\mathrm{Ni}$ & 143.2 & 6.2 & 0.26 & 385 \\
\hline & $\mathrm{P}$ & 495.0 & 0.3 & $<0.01$ & 27500 \\
\hline & $\mathrm{Pb}$ & 47.0 & 3.1 & 0.39 & 253 \\
\hline & $\mathrm{S}$ & 33.8 & 35.7 & 6.33 & 16 \\
\hline & $\mathrm{Sb}$ & 53.4 & 1.1 & 0.13 & 809 \\
\hline & $\mathrm{Se}$ & 36.0 & 345.9 & 57.62 & 2 \\
\hline & $\mathrm{Si}$ & 7183.2 & 114.0 & 0.10 & 1050 \\
\hline & $\mathrm{Sr}$ & 662.1 & 21.8 & 0.20 & 506 \\
\hline & $\mathrm{Te}$ & 37.8 & 43.1 & 6.84 & 15 \\
\hline & $\mathrm{Ti}$ & 12.1 & 0.5 & 0.26 & 403 \\
\hline & $\mathrm{Zn}$ & 542.3 & 20.7 & 0.23 & 437 \\
\hline & $\mathrm{Zr}$ & 889.5 & 10.5 & 0.07 & 1412 \\
\hline \multirow{6}{*}{ こ్ర } & $B$ & 523.7 & 141.5 & 1.62 & 62 \\
\hline & $\mathrm{Cl}$ & 3.4 & 65.5 & 116.41 & 1 \\
\hline & $\mathrm{F}$ & 13.5 & 72.8 & 32.36 & 3 \\
\hline & $\mathrm{I}$ & 33.8 & 475.9 & 84.61 & 1 \\
\hline & $\mathrm{S}$ & 33.8 & 95.0 & 16.87 & 6 \\
\hline & $\mathrm{Se}$ & 36.0 & 38.0 & 6.34 & 16 \\
\hline
\end{tabular}


Table 6.3. Particulate and Gaseous Emissions Sampling Results During Commissioning Test 2.

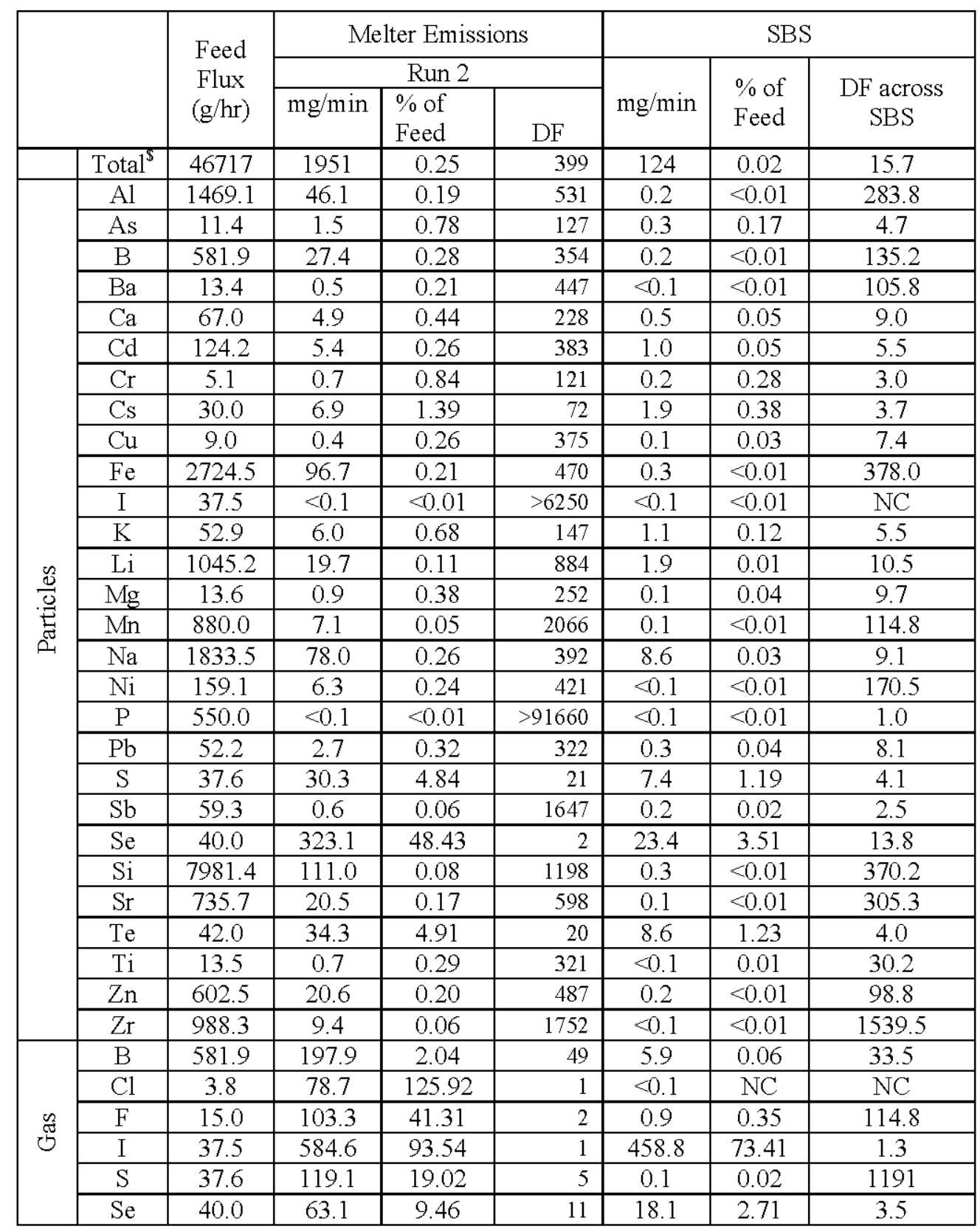

$\mathrm{NC}-$ Not calculated

$\$$ - From gravimetric analysis of filters and rinse dry downs 
Table 6.4. Particulate and Gaseous Emissions Sampling Results During Commissioning Test 3.

\begin{tabular}{|c|c|c|c|c|c|c|c|c|}
\hline & \multirow{2}{*}{$\begin{array}{l}\text { Feed } \\
\text { Flux } \\
(\mathrm{g} / \mathrm{hr})\end{array}$} & \multicolumn{3}{|c|}{ Melter Emissions* } & \multicolumn{3}{|c|}{ SBS } \\
\hline & & & $\mathrm{mg} / \mathrm{min}$ & $\begin{array}{l}\% \text { of } \\
\text { Feed }\end{array}$ & DF & $\mathrm{mg} / \mathrm{min}$ & $\begin{array}{l}\% \text { of } \\
\text { Feed }\end{array}$ & $\begin{array}{c}\text { DF across } \\
\text { SBS }\end{array}$ \\
\hline & Total $^{\#}$ & 41746 & 1704 & 0.24 & 408 & 22.1 & $<0.01$ & 77.1 \\
\hline \multirow{30}{*}{$\frac{\mathscr{U}}{\stackrel{0}{E}}$} & $\mathrm{Al}$ & 1371.2 & 47.7 & 0.21 & 479 & 0.1 & $<0.01$ & 382.0 \\
\hline & As & 10.6 & 2.5 & 1.42 & 71 & $<0.1$ & $<0.01$ & $\mathrm{NC}$ \\
\hline & $\mathrm{B}$ & 543.1 & 276.4 & 3.05 & 33 & $<0.1$ & $<0.01$ & $\mathrm{NC}$ \\
\hline & $\mathrm{Ba}$ & 12.5 & 0.5 & 0.24 & 417 & $<0.1$ & $<0.01$ & 118.8 \\
\hline & $\mathrm{Ca}$ & 62.5 & 24.9 & 2.39 & 42 & 0.4 & 0.04 & 64.8 \\
\hline & $\mathrm{Cd}$ & 116.0 & 8.6 & 0.45 & 225 & 0.1 & $<0.01$ & 121.6 \\
\hline & $\mathrm{Cl}$ & 3.5 & $41.6^{8}$ & 71.35 & 1 & N/A & $\mathrm{N} / \mathrm{A}$ & $\mathrm{NC}$ \\
\hline & $\mathrm{Cr}$ & 4.8 & 2.0 & 2.53 & 40 & $<0.1$ & 0.03 & 87.5 \\
\hline & $\mathrm{Cs}$ & 28.0 & 9.9 & 2.12 & 47 & 0.1 & 0.03 & 73.9 \\
\hline & $\mathrm{Cu}$ & 8.4 & 0.4 & 0.27 & 350 & $<0.1$ & 0.01 & 19.0 \\
\hline & $\mathrm{F}$ & 14.0 & $0.5^{\$}$ & 0.20 & 467 & N/A & N/A & $\mathrm{NC}$ \\
\hline & $\mathrm{Fe}$ & 2542.8 & 90.8 & 0.21 & 467 & 0.1 & $<0.01$ & 670.4 \\
\hline & $\mathrm{I}$ & 35.0 & 181.8 & 31.17 & 3 & $<0.1$ & $<0.01$ & $\mathrm{NC}$ \\
\hline & $\mathrm{K}$ & 49.4 & 8.8 & 1.07 & 94 & 0.2 & 0.03 & 41.0 \\
\hline & $\mathrm{Li}$ & 975.5 & 28.4 & 0.17 & 572 & 0.1 & $<0.01$ & 282.0 \\
\hline & $\mathrm{Mg}$ & 12.7 & 4.6 & 2.17 & 46 & 0.1 & 0.03 & 65.7 \\
\hline & $\mathrm{Mn}$ & 821.3 & 8.7 & 0.06 & 1573 & $<0.1$ & $<0.01$ & 493.1 \\
\hline & $\mathrm{Na}$ & 1711.3 & 661.8 & 2.32 & 43 & 0.9 & $<0.01$ & 719.5 \\
\hline & $\mathrm{Ni}$ & 148.5 & 6.0 & 0.24 & 413 & $<0.1$ & $<0.01$ & 457.3 \\
\hline & $\mathrm{P}$ & 513.3 & 0.7 & 0.01 & 12221 & $<0.1$ & $<0.01$ & $\mathrm{NC}$ \\
\hline & $\mathrm{Pb}$ & 48.7 & 3.9 & 0.48 & 208 & $<0.1$ & $<0.01$ & 188.7 \\
\hline & $\mathrm{S}$ & 35.1 & 190.2 & 32.55 & 3 & 0.2 & 0.03 & $\mathrm{NC}$ \\
\hline & $\mathrm{Sb}$ & 55.3 & 2.6 & 0.28 & 354 & $<0.1$ & $<0.01$ & 308.3 \\
\hline & $\mathrm{Se}$ & 37.4 & 400.4 & 64.31 & 2 & 3.2 & 0.51 & $\mathrm{NC}$ \\
\hline & $\mathrm{Si}$ & 7449.3 & 97.3 & 0.08 & 1276 & 0.3 & $<0.01$ & 332.8 \\
\hline & $\mathrm{Sr}$ & 686.6 & 24.1 & 0.21 & 475 & $<0.1$ & $<0.01$ & 3606.5 \\
\hline & $\mathrm{Te}$ & 39.2 & 64.4 & 9.87 & 10 & 0.2 & 0.03 & 393.0 \\
\hline & $\mathrm{Ti}$ & 12.6 & 0.4 & 0.20 & 525 & $<0.1$ & $<0.01$ & 92.4 \\
\hline & $\mathrm{Zn}$ & 562.4 & 20.9 & 0.22 & 448 & $<0.1$ & $<0.01$ & 453.0 \\
\hline & $\mathrm{Zr}$ & 922.4 & 7.7 & 0.05 & 1997 & $<0.1$ & $<0.01$ & 1020.6 \\
\hline \multirow{6}{*}{ ్ֶర } & B & 543.10 & & & & 5.7 & 0.06 & $48.5^{\&}$ \\
\hline & $\mathrm{Cl}$ & 3.50 & & & & 2.0 & 3.49 & 20.8 \\
\hline & $\mathrm{F}$ & 14.00 & & & & 0.3 & 0.15 & $\mathrm{NC}$ \\
\hline & $\mathrm{I}$ & 35.00 & & & & 102.8 & 17.63 & $1.7^{\&}$ \\
\hline & $\mathrm{S}$ & 35.07 & & & & 2.7 & 0.46 & $65.1^{\&}$ \\
\hline & $\mathrm{Se}$ & 37.36 & & & & 23.9 & 3.84 & $14.8^{8}$ \\
\hline
\end{tabular}

$\mathrm{NC}-$ Not calculated.

* Melter emissions include gas and particle fractions combined due to filter breach.

$\$ \mathrm{Cl}$ and $\mathrm{F}$ values only analyzed for gas fractions.

\# From gravimetric analysis of filters and rinse dry-downs.

$\&$ DF calculated for combined particulate and gaseous emissions. 
Table 6.5. Comparison of Total SBS Accumulations and Melter Emissions Results for DM1200 Commissioning Tests.

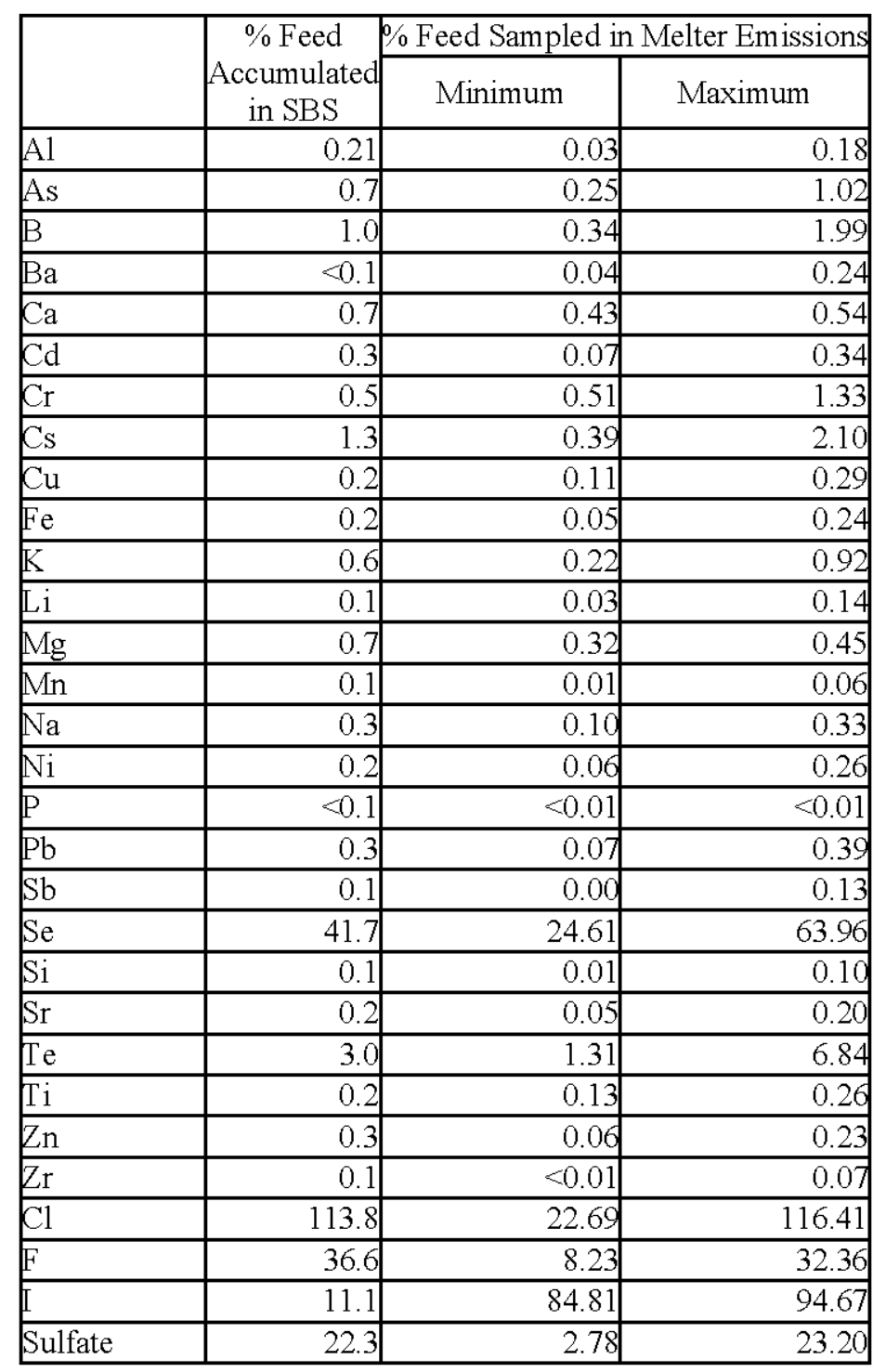


Table 6.6. Particle Size Distributions for DM1200 Melter Exhaust.

\begin{tabular}{|c|c|c|c|c|}
\hline & Particle Size (microns) & Net Weight (mg) & $\begin{array}{c}\text { Concentration } \\
\text { (mg/dscf) }\end{array}$ & Mass Fraction (\%) \\
\hline \multirow{9}{*}{ Test 1} & $>23.04$ & 0.3 & 0.0273 & 12.4 \\
\hline & $9.22-23.04$ & 0.1 & 0.0091 & 4.1 \\
\hline & $4.98-9.22$ & 1.02 & 0.0930 & 42.3 \\
\hline & $2.20-4.98$ & 0.36 & 0.0328 & 14.9 \\
\hline & $1.18-2.20$ & 0.14 & 0.0128 & 5.8 \\
\hline & $0.68-1.18$ & 0.02 & 0.0018 & 0.8 \\
\hline & $0.39-0.68$ & 0.0 & 0.0000 & 0.0 \\
\hline & $0.04-0.39$ & 0.47 & 0.0428 & 19.5 \\
\hline & Total & & & 100.0 \\
\hline \multirow{9}{*}{ Test 2} & $>24.31$ & 1.46 & 0.4885 & 10.7 \\
\hline & $10.26-24.31$ & 1.37 & 0.4583 & 10.1 \\
\hline & $5.54-10.26$ & 1.4 & 0.4684 & 10.3 \\
\hline & $2.44-5.54$ & 1.3 & 0.4349 & 9.5 \\
\hline & $1.31-2.44$ & 0.96 & 0.3212 & 7.0 \\
\hline & $0.75-1.31$ & 1.23 & 0.4115 & 9.0 \\
\hline & $0.43-0.75$ & 1.9 & 0.6424 & 14.1 \\
\hline & $0.04-0.43$ & 3.98 & 1.3315 & 29.2 \\
\hline & Total & & & 100.0 \\
\hline \multirow{9}{*}{ Test 3} & $>24.05$ & 3.54 & 0.6219 & 10.9 \\
\hline & $10.05-24.05$ & 3.95 & 0.6940 & 12.2 \\
\hline & $5.42-10.05$ & 3.18 & 0.5587 & 9.8 \\
\hline & $2.39-5.42$ & 4.6 & 0.8082 & 14.2 \\
\hline & $1.29-2.39$ & 3.22 & 0.5657 & 10.0 \\
\hline & $0.73-1.29$ & 4.14 & 0.7273 & 12.8 \\
\hline & $0.42-0.73$ & 6.8 & 1.1929 & 21.0 \\
\hline & $0.04-0.42$ & 2.94 & 0.5165 & 9.1 \\
\hline & Total & & & 100.0 \\
\hline
\end{tabular}


Table 6.7. Particle Size Distributions for SBS Exhaust.

\begin{tabular}{|c|c|c|c|c|}
\hline & Particle Size (microns) & Net Weight (mg) & $\begin{array}{c}\text { Concentration } \\
\text { (mg/dscf) }\end{array}$ & Mass Fraction (\%) \\
\hline \multirow{9}{*}{ Test 1} & $>23.60$ & 0.28 & 0.0037 & 4.03 \\
\hline & $9.67-23.60$ & 0.26 & 0.0035 & 3.74 \\
\hline & $5.22-9.67$ & 0.26 & 0.0035 & 3.74 \\
\hline & $2.30-5.22$ & 0.19 & 0.0025 & 2.73 \\
\hline & $1.24-2.30$ & 0.18 & 0.0024 & 2.59 \\
\hline & $0.70-1.24$ & 1.18 & 0.0158 & 16.98 \\
\hline & $0.41-0.70$ & 0.54 & 0.0072 & 7.77 \\
\hline & $0.04-0.41$ & 4.06 & 0.0543 & 58.42 \\
\hline & Total & & & 100.00 \\
\hline \multirow{9}{*}{ Test 2} & $>23.63$ & 0.25 & 0.0221 & 1.82 \\
\hline & $9.70-23.63$ & 0.20 & 0.0176 & 1.46 \\
\hline & $5.24-9.70$ & 0.13 & 0.0115 & 0.95 \\
\hline & $2.31-5.24$ & 0.14 & 0.0124 & 1.02 \\
\hline & $1.24-2.31$ & 0.40 & 0.0353 & 2.91 \\
\hline & $0.71-1.24$ & 4.29 & 0.3785 & 31.22 \\
\hline & $0.41-0.71$ & 4.35 & 0.3838 & 31.66 \\
\hline & $0.04-0.41$ & 3.98 & 0.3512 & 28.97 \\
\hline & Total & & & 100.00 \\
\hline \multirow{9}{*}{ Test 3} & $>23.58$ & 0.14 & 0.0205 & 4.03 \\
\hline & $9.65-23.58$ & 0.21 & 0.0307 & 6.05 \\
\hline & $5.21-9.65$ & 0.11 & 0.0161 & 3.17 \\
\hline & $2.30-5.21$ & 0.08 & 0.0117 & 2.30 \\
\hline & $1.24-2.30$ & 0.18 & 0.0263 & 5.19 \\
\hline & $0.70-1.24$ & 0.80 & 0.1169 & 23.05 \\
\hline & $0.41-0.70$ & 1.61 & 0.2352 & 46.38 \\
\hline & $0.04-0.41$ & 0.34 & 0.0497 & 9.82 \\
\hline & Total & & & 100.00 \\
\hline
\end{tabular}




\section{Table 6.8. Chemical Analysis of Particle Size Fractions for Melter Exhaust from DM1200 Commissioning Test 2.}

\begin{tabular}{|c|c|c|c|c|c|c|c|c|}
\hline $\begin{array}{c}\text { Particle Size } \\
\text { (microns) }\end{array}$ & $>24.31$ & $\begin{array}{c}10.26- \\
24.31\end{array}$ & $\begin{array}{c}5.54- \\
10.26\end{array}$ & $\begin{array}{c}2.44- \\
5.54\end{array}$ & $\begin{array}{c}1.31- \\
2.44\end{array}$ & $\begin{array}{c}0.75- \\
1.31\end{array}$ & $\begin{array}{c}0.43- \\
0.75\end{array}$ & $\begin{array}{c}0.04- \\
0.43\end{array}$ \\
\hline Total Mass (m) & 1.5 & 1.4 & 1.4 & 1.3 & 1.0 & 1.2 & 1.9 & 4.0 \\
\hline $\begin{array}{c}\text { Mass Fraction } \\
(\%)\end{array}$ & 10.7 & 10.1 & 10.3 & 9.6 & 7.1 & 9.0 & 14.0 & 29.3 \\
\hline $\mathrm{Al}$ & 3.4 & 3.2 & 2.1 & 0.7 & 1.0 & 0.4 & $<0.1$ & $<0.1$ \\
\hline $\mathrm{As}$ & $<0.1$ & $<0.1$ & $<0.1$ & 0.2 & $<0.1$ & $<0.1$ & 0.2 & 0.3 \\
\hline $\mathrm{B}$ & 1.2 & 0.7 & 0.6 & 0.1 & 0.4 & 0.2 & $<0.1$ & $<0.1$ \\
\hline $\mathrm{Ba}$ & $<0.1$ & $<0.1$ & $<0.1$ & $<0.1$ & $<0.1$ & $<0.1$ & $<0.1$ & $<0.1$ \\
\hline $\mathrm{Ca}$ & 0.5 & 0.5 & 1.4 & 0.2 & 1.5 & 0.4 & $<0.1$ & $<0.1$ \\
\hline $\mathrm{Cd}$ & 0.2 & 0.2 & 0.2 & 0.3 & 0.3 & 0.7 & 0.7 & 0.8 \\
\hline $\mathrm{Cr}$ & $<0.1$ & $<0.1$ & $<0.1$ & $<0.1$ & $<0.1$ & 0.2 & 0.2 & 0.2 \\
\hline $\mathrm{Cs}$ & $<0.1$ & $<0.1$ & $<0.1$ & $<0.1$ & $<0.1$ & 1.9 & 2.2 & 2.3 \\
\hline $\mathrm{Cu}$ & $<0.1$ & 0.1 & 0.5 & 0.4 & 1.0 & $<0.1$ & 0.5 & $<0.1$ \\
\hline $\mathrm{Fe}$ & 5.5 & 6.6 & 6.9 & 8.1 & 6.3 & 4.2 & 0.7 & 0.2 \\
\hline $\mathrm{I}$ & $<0.1$ & $<0.1$ & $<0.1$ & $<0.1$ & $<0.1$ & $<0.1$ & $<0.1$ & $<0.1$ \\
\hline $\mathrm{K}$ & $<0.1$ & 0.1 & 0.1 & 0.2 & 0.2 & 0.5 & 0.7 & 0.7 \\
\hline $\mathrm{Li}$ & 0.8 & 0.8 & 0.9 & 1.0 & 0.9 & 1.7 & 1.5 & 1.6 \\
\hline $\mathrm{Mg}$ & $<0.1$ & 0.1 & 0.3 & $<0.1$ & 0.4 & 0.1 & $<0.1$ & $<0.1$ \\
\hline $\mathrm{Mn}$ & 1.0 & 0.5 & 0.4 & 0.2 & 0.2 & $<0.1$ & $<0.1$ & $<0.1$ \\
\hline $\mathrm{Na}$ & 7.7 & 4.0 & 3.8 & 4.0 & 3.5 & 7.1 & 6.6 & 6.4 \\
\hline $\mathrm{Ni}$ & 0.2 & 0.8 & 1.5 & 1.3 & 2.4 & $<0.1$ & 1.0 & $<0.1$ \\
\hline $\mathrm{P}$ & $<0.1$ & $<0.1$ & $<0.1$ & 0.3 & $<0.1$ & $<0.1$ & $<0.1$ & $<0.1$ \\
\hline $\mathrm{Pb}$ & 0.1 & 0.1 & 0.1 & 0.2 & 0.2 & 0.3 & 0.2 & 0.3 \\
\hline $\mathrm{S}$ & $<0.1$ & $<0.1$ & $<0.1$ & $<0.1$ & $<0.1$ & 2.9 & 3.7 & 5.6 \\
\hline $\mathrm{Sb}$ & $<0.1$ & $<0.1$ & $<0.1$ & $<0.1$ & $<0.1$ & $<0.1$ & $<0.1$ & $<0.1$ \\
\hline $\mathrm{Se}$ & 9.6 & 18.1 & 18.1 & 22.4 & 21.0 & 27.7 & 21.8 & 24.4 \\
\hline $\mathrm{Si}$ & 11.7 & 8.6 & 8.3 & 2.5 & 5.2 & 2.3 & $<0.1$ & 0.2 \\
\hline $\mathrm{Sr}$ & 1.1 & 1.2 & 1.3 & 1.5 & 1.3 & 0.8 & 0.1 & $<0.1$ \\
\hline $\mathrm{Te}$ & 0.7 & 1.2 & 1.6 & 3.5 & 4.8 & 8.5 & 6.9 & 7.7 \\
\hline $\mathrm{Ti}$ & $<0.1$ & $<0.1$ & $<0.1$ & $<0.1$ & 0.1 & $<0.1$ & $<0.1$ & 0.2 \\
\hline $\mathrm{Zn}$ & 1.1 & 1.2 & 1.3 & 1.4 & 1.0 & 0.7 & 0.2 & 0.1 \\
\hline $\mathrm{Zr}$ & 1.6 & 0.7 & 0.4 & 0.1 & $<0.1$ & $<0.1$ & $<0.1$ & $<0.1$ \\
\hline $\mathrm{Mass} \mathrm{Fraction}$ & 46.4 & 48.9 & 49.8 & 48.4 & 51.7 & 60.7 & 47.1 & 51.1 \\
\hline $\mathrm{Sum}(\%)$ & & & & & & & & \\
\hline
\end{tabular}


Table 6.9. Chemical Analysis of Particle Size Fractions for Melter Exhaust from DM1200 Commissioning Test 3.

\begin{tabular}{|c|c|c|c|c|c|c|c|c|}
\hline $\begin{array}{c}\text { Particle Size } \\
\text { (microns) }\end{array}$ & $\begin{array}{c}>24 . \\
05\end{array}$ & $\begin{array}{c}10.05- \\
24.05 \\
\end{array}$ & $\begin{array}{l}5.42- \\
10.05 \\
\end{array}$ & $\begin{array}{c}2.39- \\
5.42 \\
\end{array}$ & $\begin{array}{c}1.29- \\
2.39 \\
\end{array}$ & $\begin{array}{c}0.73- \\
1.29 \\
\end{array}$ & $\begin{array}{c}0.42- \\
0.73 \\
\end{array}$ & $\begin{array}{c}0.04- \\
0.42 \\
\end{array}$ \\
\hline $\begin{array}{l}\text { Total Mass } \\
\text { (mg) }\end{array}$ & 3.5 & 4.0 & 3.2 & 4.6 & 3.2 & 4.1 & 6.8 & 2.9 \\
\hline $\begin{array}{c}\text { Mass Fraction } \\
(\%)\end{array}$ & 10.9 & 12.2 & 9.8 & 14.2 & 10.0 & 12.8 & 21.0 & 9.1 \\
\hline $\mathrm{Al}$ & 4.2 & 3.5 & 1.8 & 0.7 & 0.3 & $<0.1$ & $<0.1$ & 0.1 \\
\hline As & $<0.1$ & $<0.1$ & 0.2 & 0.2 & 0.2 & 0.4 & 0.5 & 0.5 \\
\hline$B$ & 2.5 & 2.3 & 1.8 & 0.8 & 0.3 & 0.2 & 0.1 & 0.1 \\
\hline $\mathrm{Ba}$ & $<0.1$ & $<0.1$ & $<0.1$ & $<0.1$ & $<0.1$ & $<0.1$ & $<0.1$ & $<0.1$ \\
\hline $\mathrm{Ca}$ & 0.1 & 0.2 & 0.3 & 0.3 & 0.2 & $<0.1$ & $<0.1$ & $<0.1$ \\
\hline $\mathrm{Cd}$ & 0.3 & 0.3 & 0.3 & 0.4 & 0.6 & 1.0 & 1.1 & 1.2 \\
\hline $\mathrm{Cr}$ & $<0.1$ & $<0.1$ & $<0.1$ & $<0.1$ & 0.1 & 0.4 & 0.2 & 0.3 \\
\hline $\mathrm{Cs}$ & 0.2 & 0.2 & 0.3 & 0.4 & 0.8 & 1.7 & 1.9 & 1.9 \\
\hline $\mathrm{Cu}$ & $<0.1$ & 0.3 & 0.1 & 0.5 & 0.5 & 0.3 & 0.2 & $<0.1$ \\
\hline $\mathrm{Fe}$ & 6.0 & 7.3 & 8.6 & 10.4 & 9.3 & 2.8 & 0.2 & 0.4 \\
\hline $\mathrm{I}$ & $<0.1$ & $<0.1$ & $<0.1$ & $<0.1$ & $<0.1$ & $<0.1$ & $<0.1$ & $<0.1$ \\
\hline $\mathrm{K}$ & $<0.1$ & $<0.1$ & 0.2 & 0.2 & 0.3 & 0.6 & 0.7 & 0.9 \\
\hline $\mathrm{Li}$ & 1.3 & 1.5 & 1.6 & 1.5 & 1.5 & 1.8 & 1.9 & 1.8 \\
\hline $\mathrm{Mg}$ & $<0.1$ & $<0.1$ & $<0.1$ & $<0.1$ & $<0.1$ & $<0.1$ & $<0.1$ & $<0.1$ \\
\hline $\mathrm{Mn}$ & 1.0 & 0.6 & 0.4 & 0.2 & 0.1 & $<0.1$ & $<0.1$ & $<0.1$ \\
\hline $\mathrm{Na}$ & 4.1 & 4.2 & 4.5 & 4.8 & 5.2 & 7.4 & 7.8 & 8.6 \\
\hline $\mathrm{Ni}$ & 0.3 & 1.1 & 0.8 & 1.2 & 1.2 & 0.7 & 0.4 & $<0.1$ \\
\hline $\mathrm{P}$ & $<0.1$ & $<0.1$ & $<0.1$ & $<0.1$ & $<0.1$ & 0.3 & $<0.1$ & $<0.1$ \\
\hline $\mathrm{Pb}$ & 0.1 & 0.1 & 0.2 & 0.2 & 0.2 & 0.3 & 0.3 & 0.4 \\
\hline $\mathrm{S}$ & $<0.1$ & $<0.1$ & 1.0 & 1.5 & 3.0 & 6.5 & 7.4 & 7.7 \\
\hline $\mathrm{Sb}$ & $<0.1$ & $<0.1$ & $<0.1$ & $<0.1$ & 0.1 & 0.3 & 0.3 & 0.3 \\
\hline $\mathrm{Se}$ & 6.8 & 12.2 & 14.2 & 17.1 & 18.9 & 20.6 & 22.4 & 23.0 \\
\hline $\mathrm{Si}$ & 10.8 & 8.1 & 5.8 & 2.7 & 1.3 & 0.3 & $<0.1$ & 0.2 \\
\hline $\mathrm{Sr}$ & 1.4 & 1.6 & 1.9 & 2.3 & 1.6 & 0.3 & $<0.1$ & $<0.1$ \\
\hline $\mathrm{Te}$ & 0.7 & 1.2 & 2.2 & 4.6 & 7.0 & 7.7 & 8.0 & 8.6 \\
\hline $\mathrm{Ti}$ & $<0.1$ & $<0.1$ & $<0.1$ & $<0.1$ & $<0.1$ & $<0.1$ & $<0.1$ & $<0.1$ \\
\hline $\mathrm{Zn}$ & 1.4 & 1.5 & 1.7 & 1.9 & 1.4 & 0.4 & 0.2 & 0.3 \\
\hline $\mathrm{Zr}$ & 1.8 & 0.7 & 0.4 & 0.1 & $<0.1$ & $<0.1$ & $<0.1$ & $<0.1$ \\
\hline $\begin{array}{c}\text { Mass Fraction } \\
\text { Sum }(\%)\end{array}$ & 43.0 & 47.0 & 48.3 & 51.9 & 54.0 & 53.8 & 53.7 & 56.3 \\
\hline
\end{tabular}


Table 6.10. Average Concentrations [ppm] of Selected Species in Off-Gas Measured by FTIR Spectroscopy during DuraMelter 1200 AZ-101 Commissioning Tests.

\begin{tabular}{|c|c|c|c|c|c|c|c|c|c|}
\hline Test \# & & $\begin{array}{c}\mathbf{1} \\
/ 01-05 / 11\end{array}$ & & & $\begin{array}{c}\mathbf{2} \\
/ 01-05 / 16\end{array}$ & & & $\begin{array}{c}\mathbf{3} \\
01-05 / 23\end{array}$ & \\
\hline Port * & $\begin{array}{c}\text { Melter } \\
\text { Outlet }\end{array}$ & $\begin{array}{c}\text { SBS } \\
\text { Outlet }\end{array}$ & $\begin{array}{l}\text { WESP } \\
\text { Outlet }\end{array}$ & $\begin{array}{l}\text { Melter } \\
\text { Outlet }\end{array}$ & $\begin{array}{c}\text { SBS } \\
\text { Outlet }\end{array}$ & $\begin{array}{l}\text { WESP } \\
\text { Outlet }\end{array}$ & $\begin{array}{c}\text { Melter } \\
\text { Outlet }\end{array}$ & $\begin{array}{c}\text { SBS } \\
\text { Outlet }\end{array}$ & $\begin{array}{l}\text { WESP } \\
\text { Outlet }\end{array}$ \\
\hline Total Sampling Time $[\mathrm{h}]$ & 6.6 & 8.8 & 8.1 & 4.0 & 5.5 & 6.8 & 1.4 & 4.8 & 6.9 \\
\hline $\mathrm{NO}$ & 160.2 & 297.0 & 206.4 & 531.3 & 683.5 & 502.6 & 538.0 & 693.4 & 633.3 \\
\hline $\mathrm{N}_{2} \mathrm{O}$ & 2.8 & 4.6 & 3.4 & 7.1 & 12.0 & 9.0 & 5.6 & 7.8 & 7.7 \\
\hline $\mathrm{NO}_{2}$ & 21.9 & 37.6 & 34.9 & 38.6 & 83.7 & 92.8 & 5.1 & 53.4 & 88.1 \\
\hline $\mathrm{HCN}$ & $<1.0$ & $<1.0$ & $<1.0$ & $<1.0$ & 1.4 & 1.0 & $<1.0$ & 1.3 & 1.3 \\
\hline $\mathrm{HNO}_{2}$ & $<1.0$ & $<1.0$ & $<1.0$ & $<1.0$ & 1.4 & 1.3 & $<1.0$ & $<1.0$ & 1.5 \\
\hline $\mathrm{HNO}_{3}$ & $<1.0$ & $<1.0$ & $<1.0$ & $<1.0$ & $<1.0$ & $<1.0$ & $<1.0$ & $<1.0$ & $<1.0$ \\
\hline $\mathrm{NH}_{3}$ & $<1.0$ & $<1.0$ & $<1.0$ & $<1.0$ & $<1.0$ & $<1.0$ & $<1.0$ & $<1.0$ & $<1.0$ \\
\hline Acetonitrile & $<1.0$ & $<1.0$ & $<1.0$ & 1.8 & $<1.0$ & $<1.0$ & 3.2 & $<1.0$ & $<1.0$ \\
\hline Acrylonitrile & $<1.0$ & $<1.0$ & $<1.0$ & $<1.0$ & $<1.0$ & $<1.0$ & $<1.0$ & $<1.0$ & $<1.0$ \\
\hline $\mathrm{HCl}$ & 1.2 & $<1.0$ & $<1.0$ & 5.4 & $<1.0$ & $<1.0$ & 2.2 & $<1.0$ & $<1.0$ \\
\hline $\mathrm{HF}$ & 4.6 & $<1.0$ & $<1.0$ & 16.2 & 1.0 & $<1.0$ & 10.9 & 1.1 & $<1.0$ \\
\hline $\mathrm{SO}_{2}$ & $<1.0$ & $<1.0$ & $<1.0$ & 8.8 & $<1.0$ & $<1.0$ & 5.4 & $<1.0$ & $<1.0$ \\
\hline $\mathrm{CO}$ & $<1.0$ & $<1.0$ & $<1.0$ & 1.3 & 2.1 & 1.7 & 1.7 & 2.6 & 2.2 \\
\hline $\mathrm{CO}_{2}[\%]$ & 0.3 & 0.5 & 0.4 & 0.8 & 1.2 & 0.9 & 0.7 & 1.1 & 1.0 \\
\hline $\mathrm{H}_{2} \mathrm{O}[\%]$ & 8.4 & 3.1 & 3.3 & 23.1 & 4.5 & 5.5 & 38.5 & 5.8 & 5.9 \\
\hline
\end{tabular}

* NOTE: Each of the three ports was samples sequentially, not simultaneously, and therefore each data set corresponds to a different time interval. 
Table 6.11. Average $\mathrm{NO}$ and $\mathrm{NO}_{2}$ Fluxes in Off-Gas Measured by FTIR Spectroscopy during DuraMelter 1200 AZ-101 Commissioning Tests.

\begin{tabular}{|c|c|c|c|c|}
\hline \multirow{2}{*}{ Test \# } & $\begin{array}{c}\text { Run Time Range } \\
{[\mathrm{h}]}\end{array}$ & $\mathrm{NO}[\mathrm{mol} / \mathrm{h}]$ & $\mathrm{NO} 2[\mathrm{~mol} / \mathrm{h}]$ & Feed $[\mathrm{mol} / \mathrm{h}]$ \\
\hline \multirow{5}{*}{1} & $4.80-9.03$ & 7.9 & 0.9 & 5.2 \\
\cline { 2 - 5 } & $31.28-33.05$ & 7.1 & 0.8 & 4.6 \\
\cline { 2 - 5 } & $49.55-55.43$ & 1.9 & 0.4 & 1.3 \\
\cline { 2 - 5 } & $73.69-80.21$ & 2.3 & 0.4 & 1.6 \\
\cline { 2 - 5 } & $96.70-103.35$ & 1.6 & 0.3 & 1.3 \\
\cline { 2 - 5 } & $1.82-8.82$ & 6.8 & 0.7 & 5.3 \\
\cline { 2 - 5 } & $25.51-32.63$ & 9.4 & 1.2 & 6.1 \\
\hline \multirow{3}{*}{3} & $48.94-52.07$ & 10.1 & 1.6 & 7.7 \\
\cline { 2 - 5 } & $2.87-9.43$ & 9.9 & 0.8 & 6.0 \\
\cline { 2 - 5 } & $25.37-29.88$ & 9.4 & 0.9 & 5.5 \\
\hline
\end{tabular}




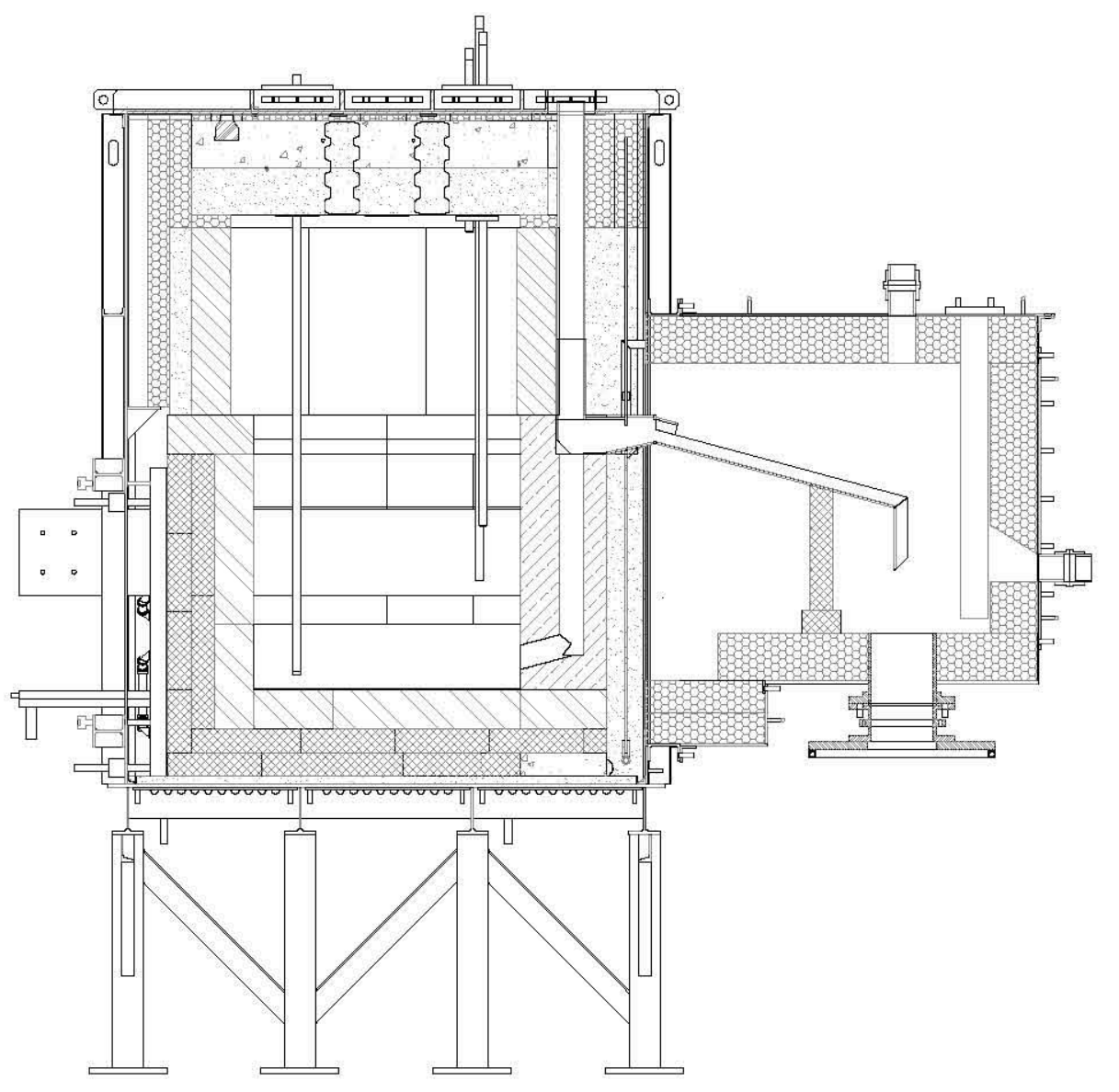

Figure 1.1 Cross-section of the DM1200 melter through the discharge chamber. 
The Catholic University of America

Vitreous State Laboratory
ORP-5143, , RqM. Glter 1200 Start-Up Tests with AZ-101

Final Report, VSL-01R0100-2, Rev. 0

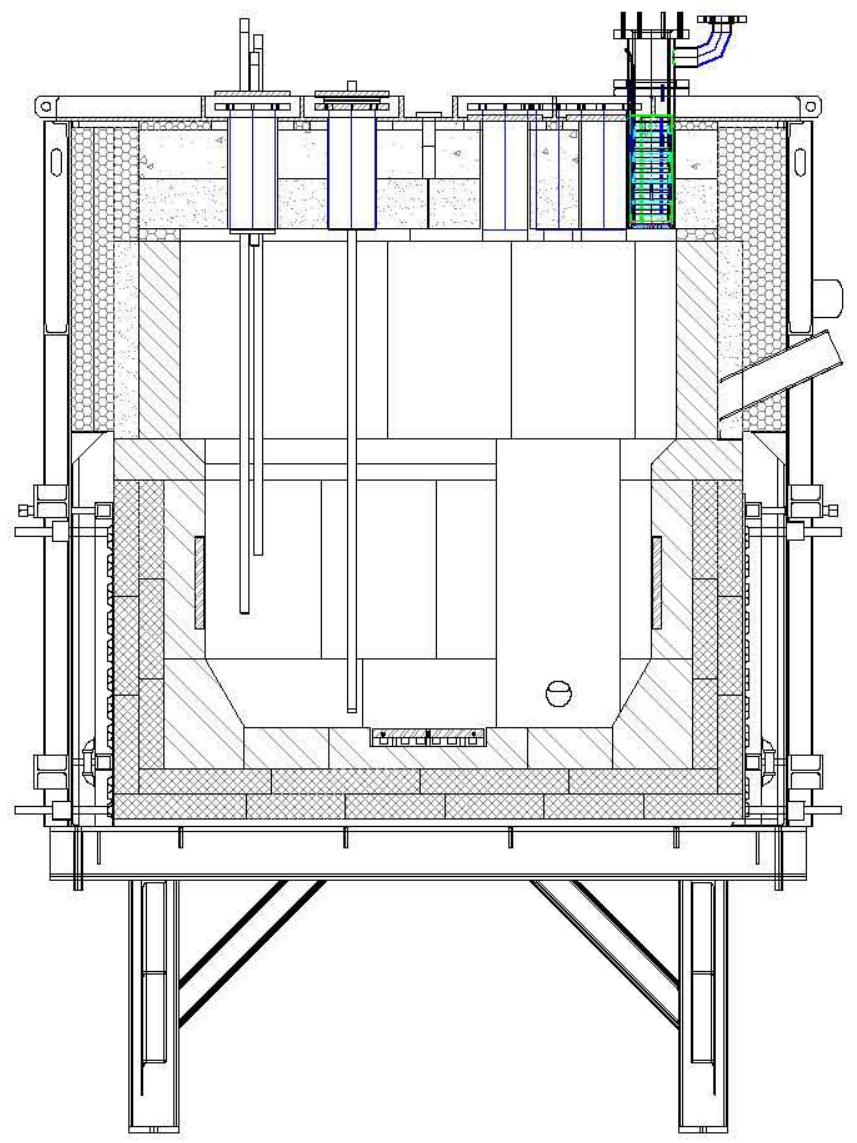

Figure 1.2. Cross-section of the DM1200 melter showing electrodes. 
NoTes:

1. SEFFUEN GAS SAMPLNG LOCATIONS

[5.] OPTIONAL GAS SAMPLNG LOCATIONS

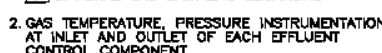

3. AUI COOMPONENIS STUATED WITHIN CLOSED

4. CATAYST EEDS USED FOR RESGARCH PLRPOSES
(USE IS OPTIONAL)

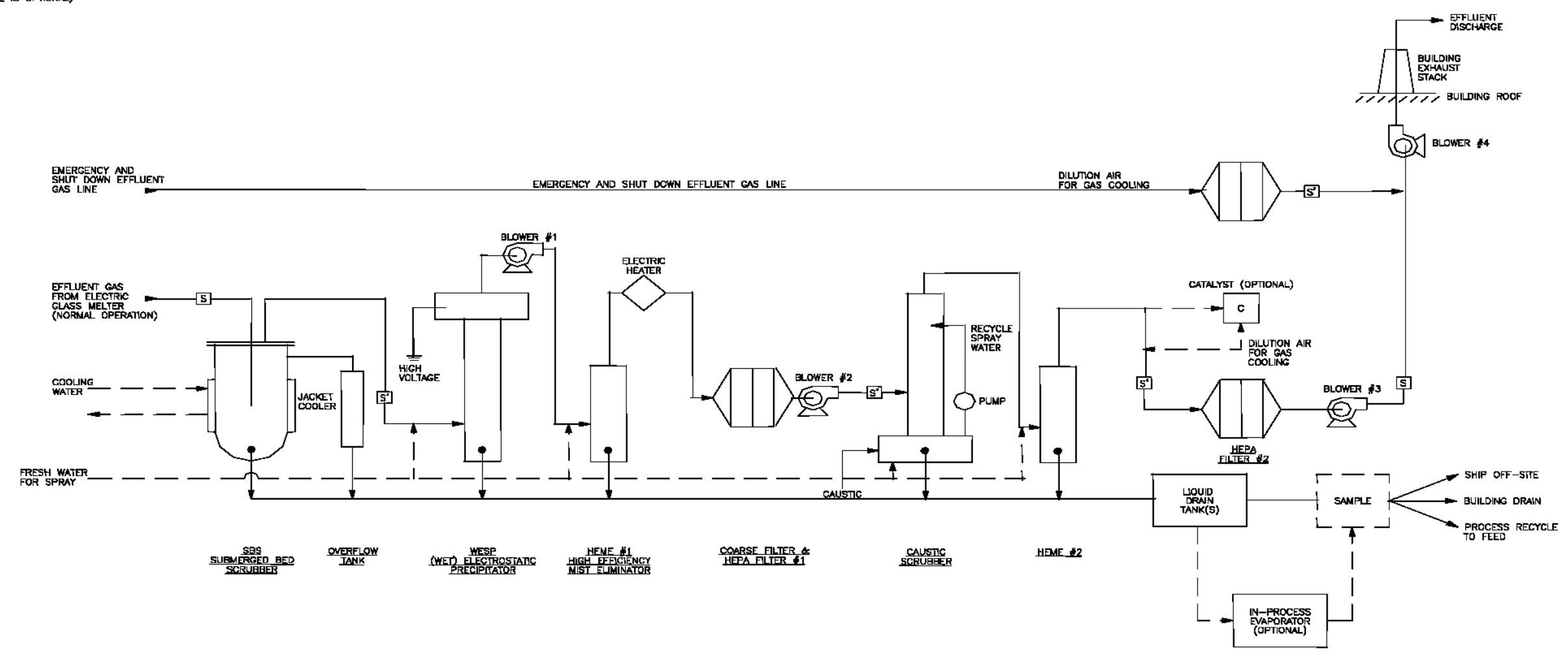

Figure 1.3. Schematic diagram of the DM1200 off-gas system. 


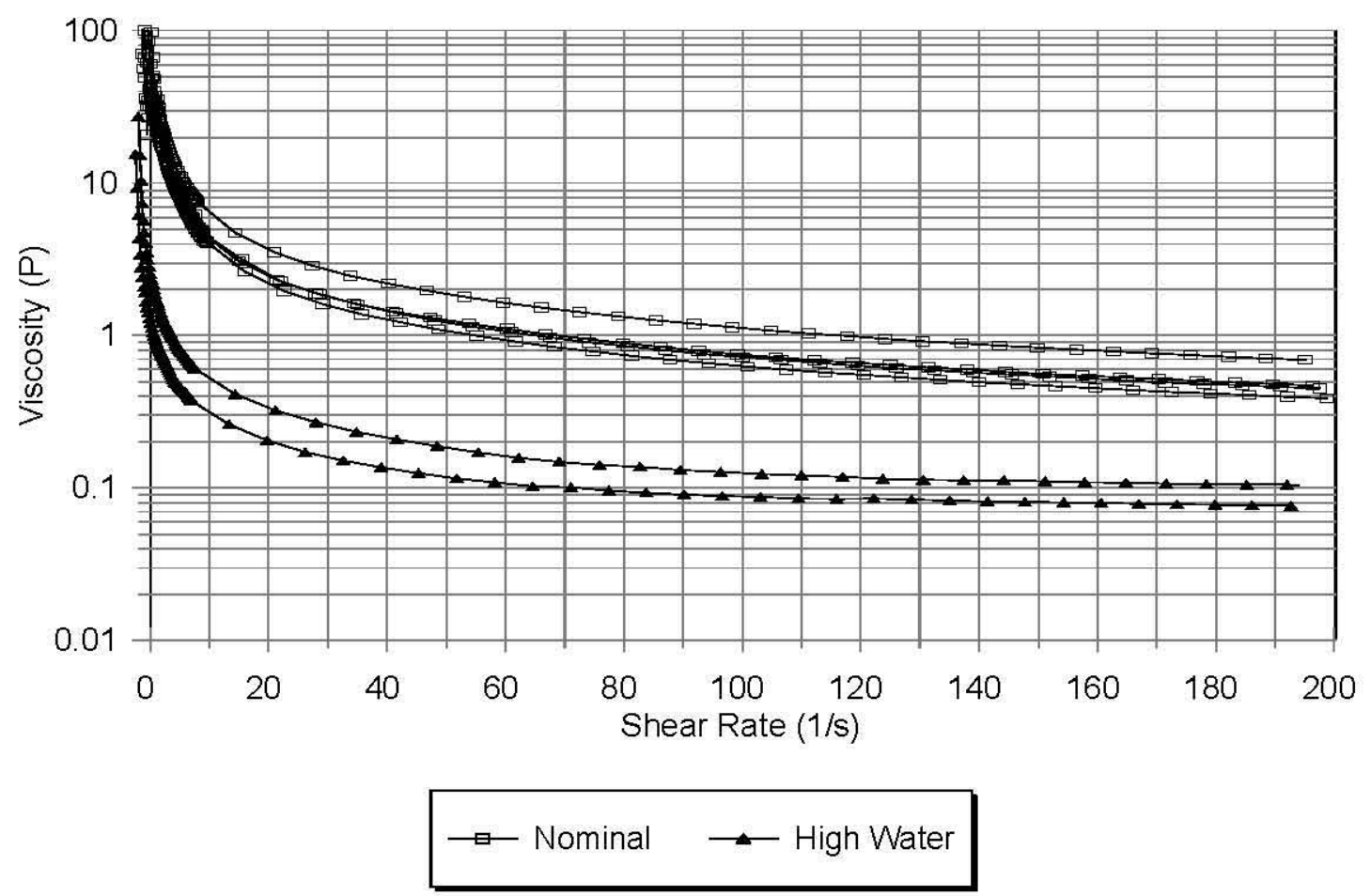

Figure 2.1. Rheograms comparing AZ-101 melter feeds from DM1200 commissioning at two solids contents. 


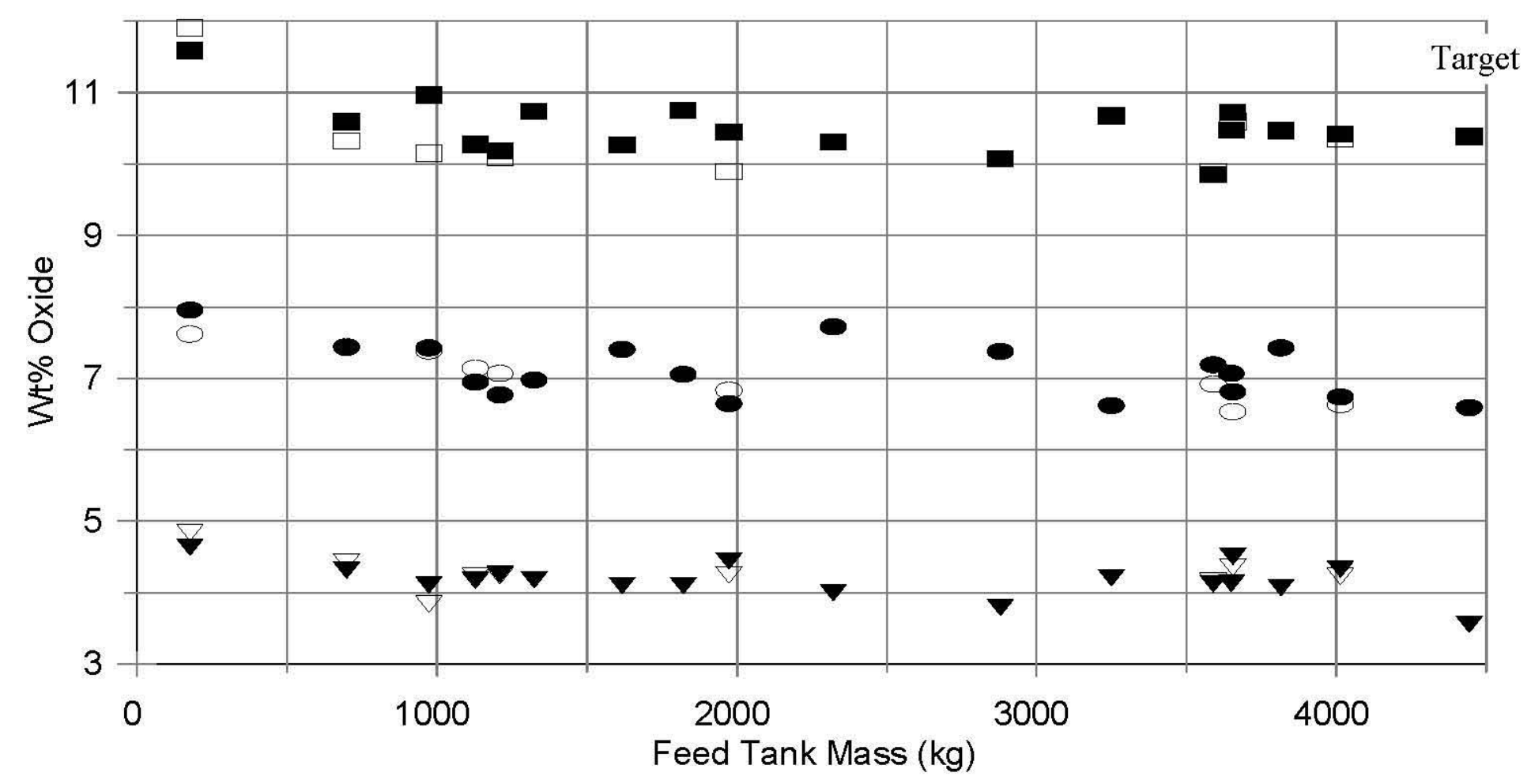

- $\begin{array}{llllllllllll} & \mathrm{Fe} \text { (tank) } & \square & \mathrm{Fe} \text { (line) } & -\mathrm{Na} \text { (tank) } & 0 & \mathrm{Na} \text { (line) } & \boldsymbol{\nabla} & \mathrm{Zr} \text { (tank) } & \nabla & \mathrm{Zr} \text { (line) }\end{array}$

Figure 2.2. Analysis of select elements in feed samples from DM1200 commissioning tests. 


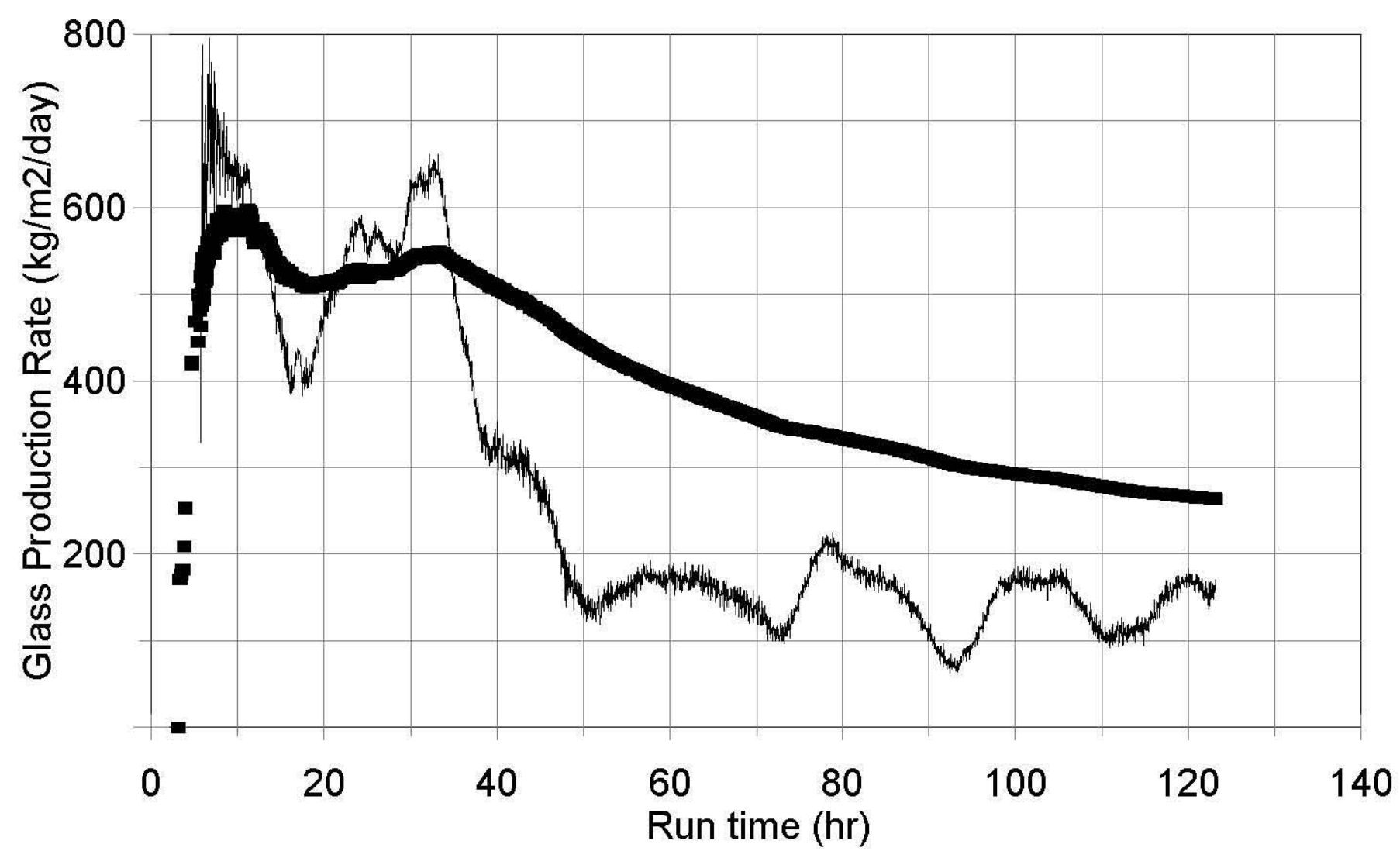

\section{$5 \mathrm{hr}$ Moving Avg. - Cumulative}

Figure 3.1. Glass production rates for DM1200 commissioning Test 1 (AZ-101 570 g/I with no bubbling). 


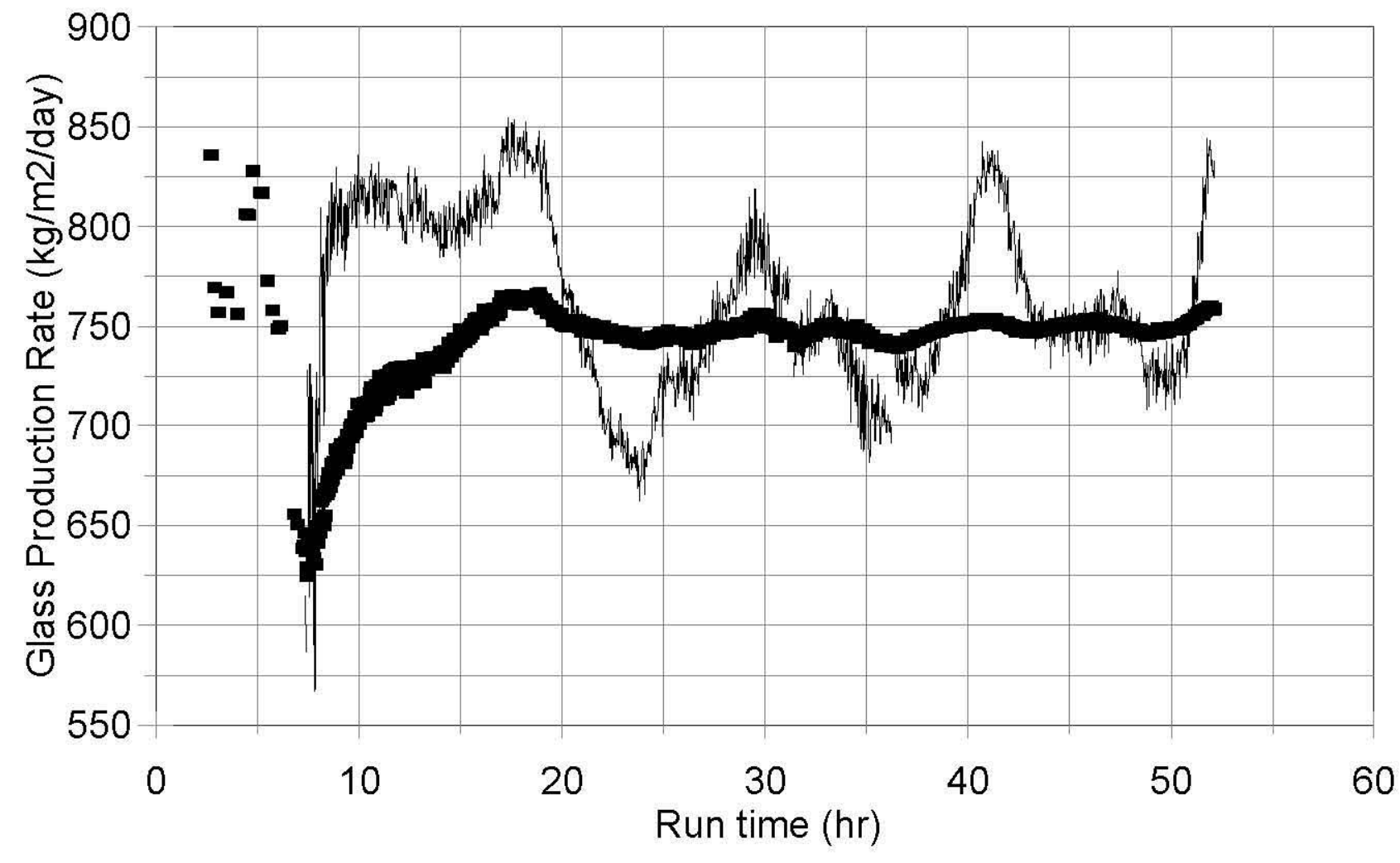

5 hr Moving Avg. - Cumulative

Figure 3.2. Glass production rates for DM1200 commissioning Test 2 (AZ-101 $570 \mathrm{~g} / \mathrm{l}$ with bubbling). 


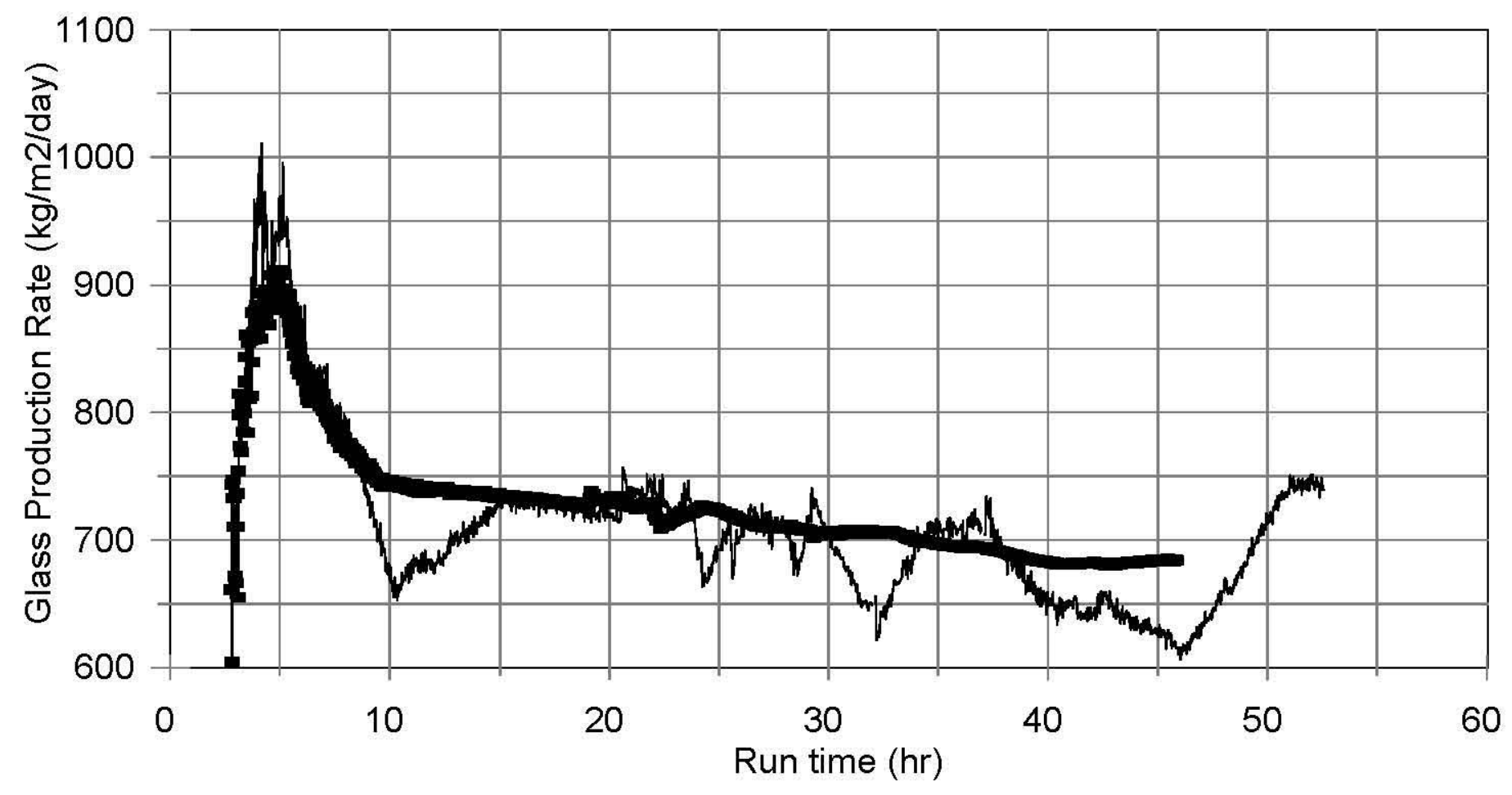

\section{$5 \mathrm{hr}$ Moving Avg. -- Cumulative}

Fig

ure 3.3. Glass production rates for DM1200 commissioning Test 3 (AZ-101 $350 \mathrm{~g} / \mathrm{l}$ with bubbling). 


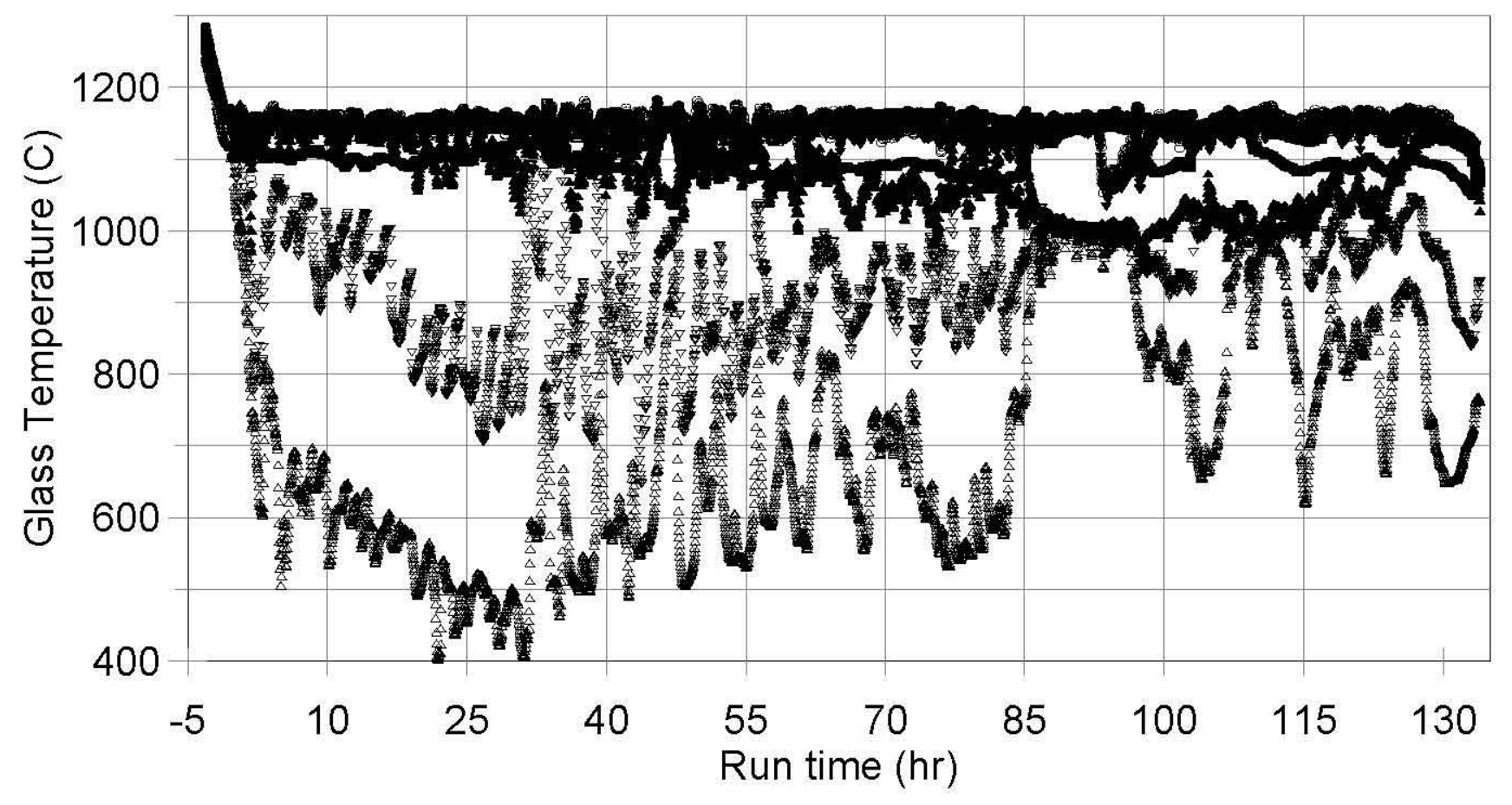
- 1 "from floor
$13^{\prime \prime}$ from floor
$18^{\prime \prime}$ from floor
$27^{\prime \prime}$ from floor
- 9" from floor
18" from floor
- 24 " from floor
$\triangle \quad 30$ " from floor

Figure 3.4. Glass temperature for DM1200 commissioning Test 1 (AZ-101 570 g/I with no bubbling). 


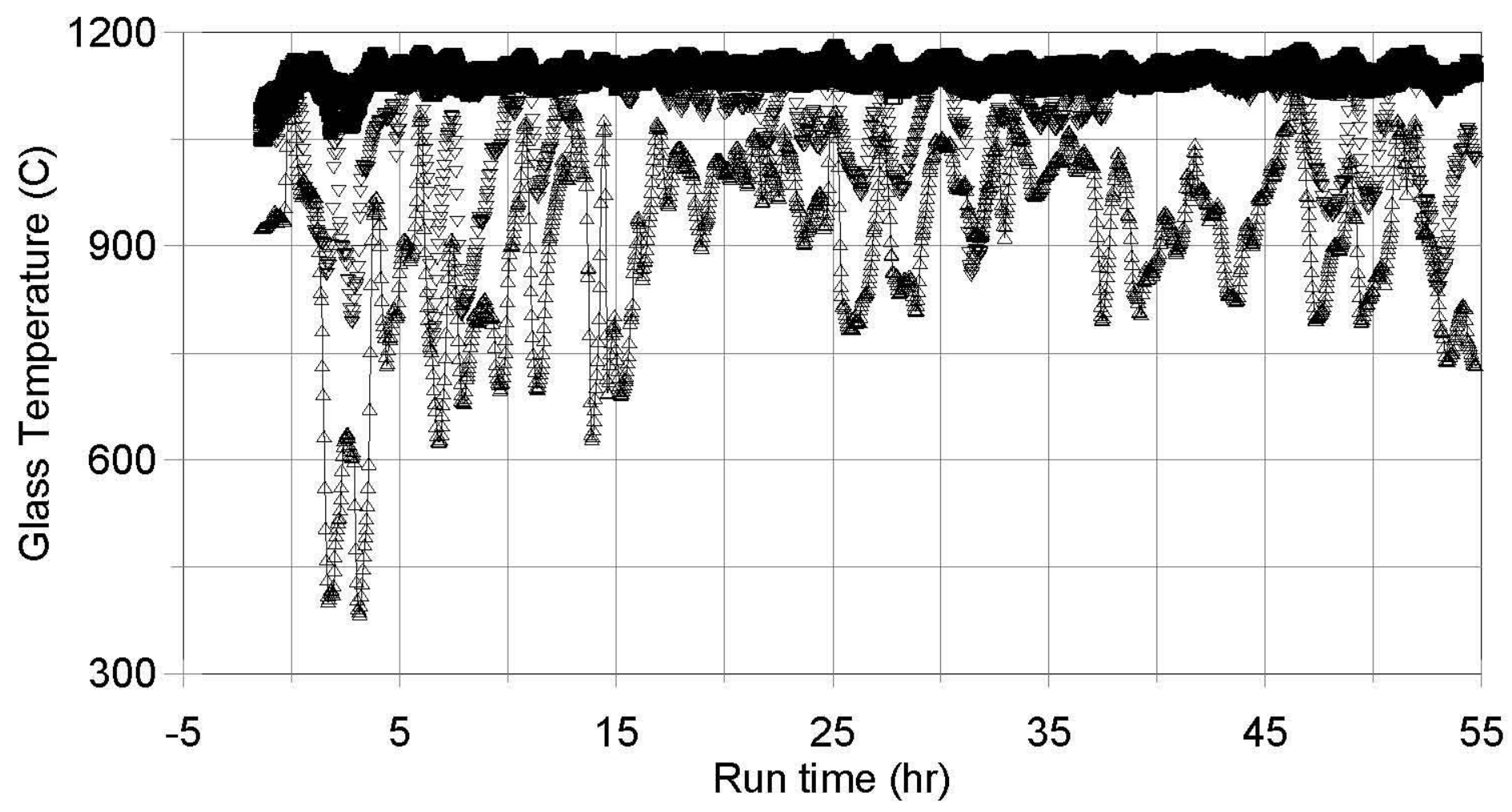

- 1 " from floor

13" from floor

- 18" from floor

27 " from floor

- 9" from floor

z 18 " from floor

- 24 " from floor

30 " from floor

Figure 3.5. Glass temperature for DM1200 commissioning Test 2 (AZ-101 $570 \mathrm{~g} / \mathrm{l}$ with bubbling). 


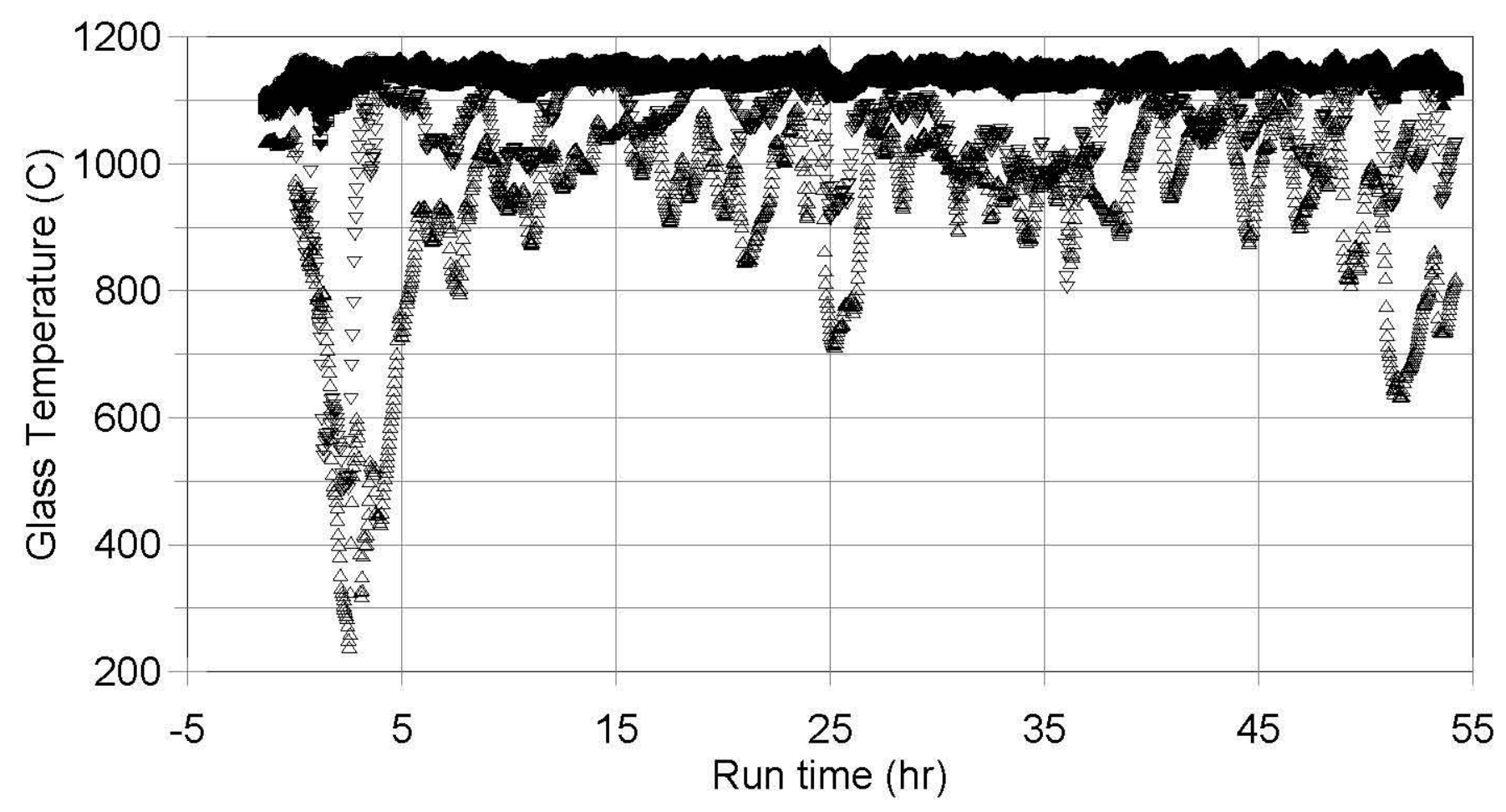

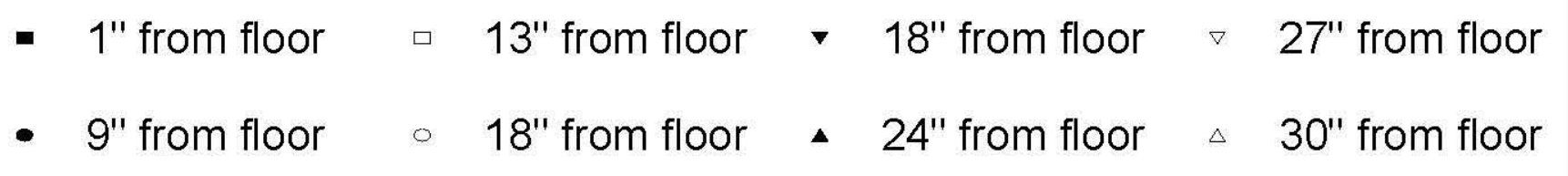

Figure 3.6. Glass temperatures for DM1200 commissioning Test 3 (AZ-101 $350 \mathrm{~g} / \mathrm{l}$ with bubbling). 


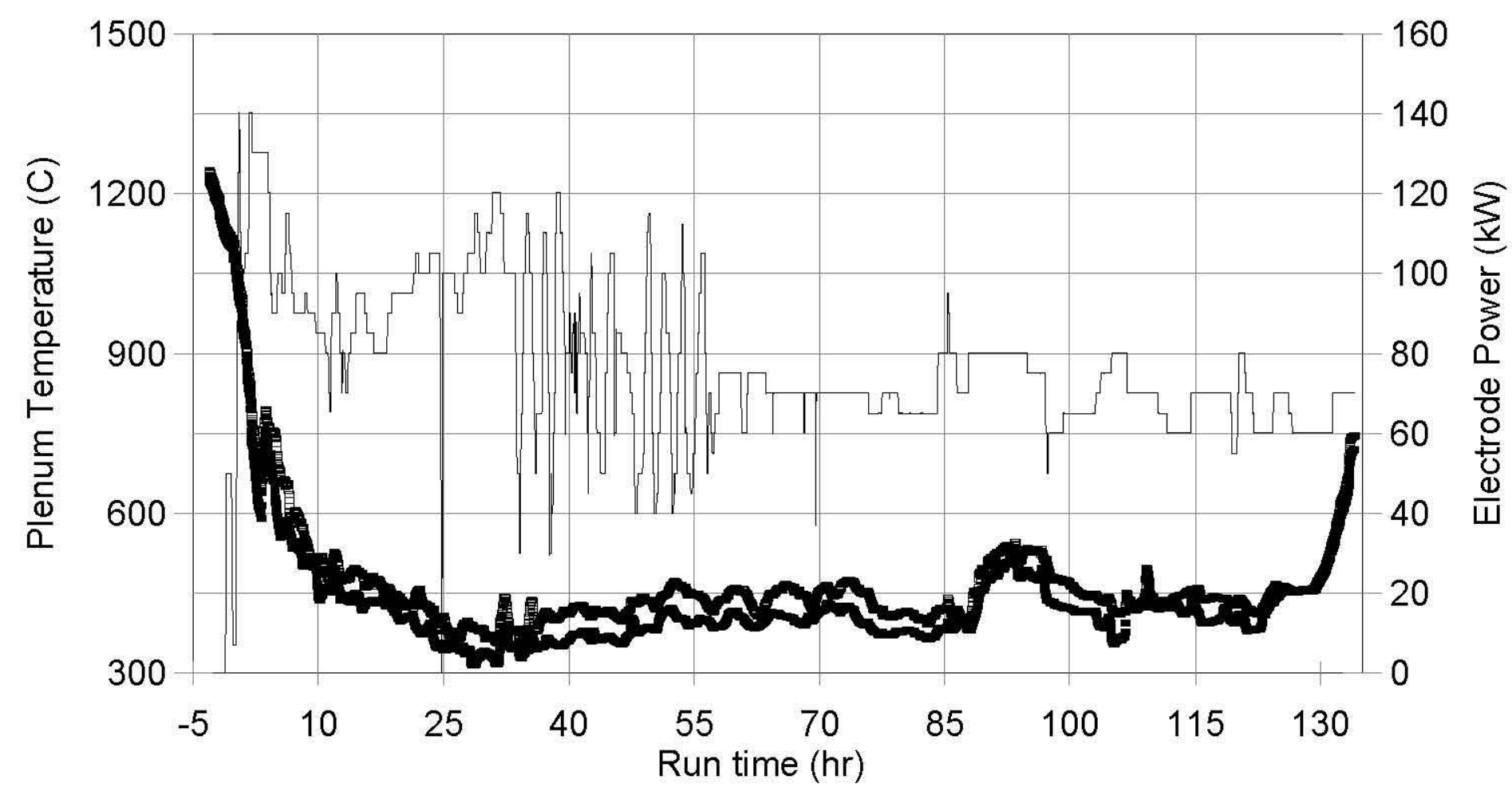

$$
\text { - 8" below ceiling _ } \quad 17 \text { " below ceiling ___ Electrode power }
$$

Figure 3.7. Plenum temperatures and electrode power for DM1200 commissioning Test 1 (AZ-101 570 g/l with no bubbling). 


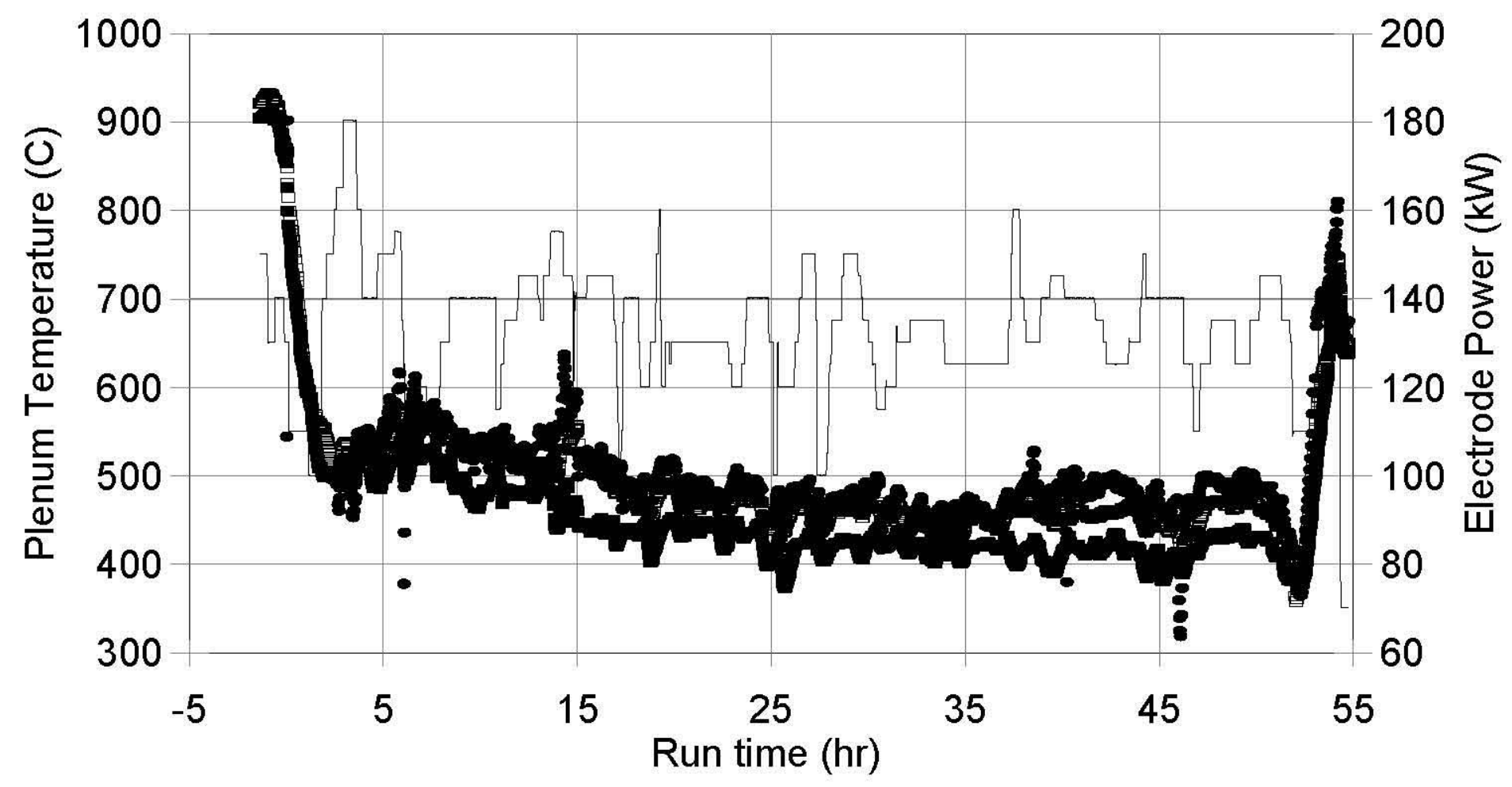
ㄷ 8" below ceiling
- 17 " below ceiling
- Exposed
Electrode power

Figure 3.8. Plenum temperatures and electrode power for DM1200 commissioning Test 2 (AZ-101 570 g/l with bubbling). 


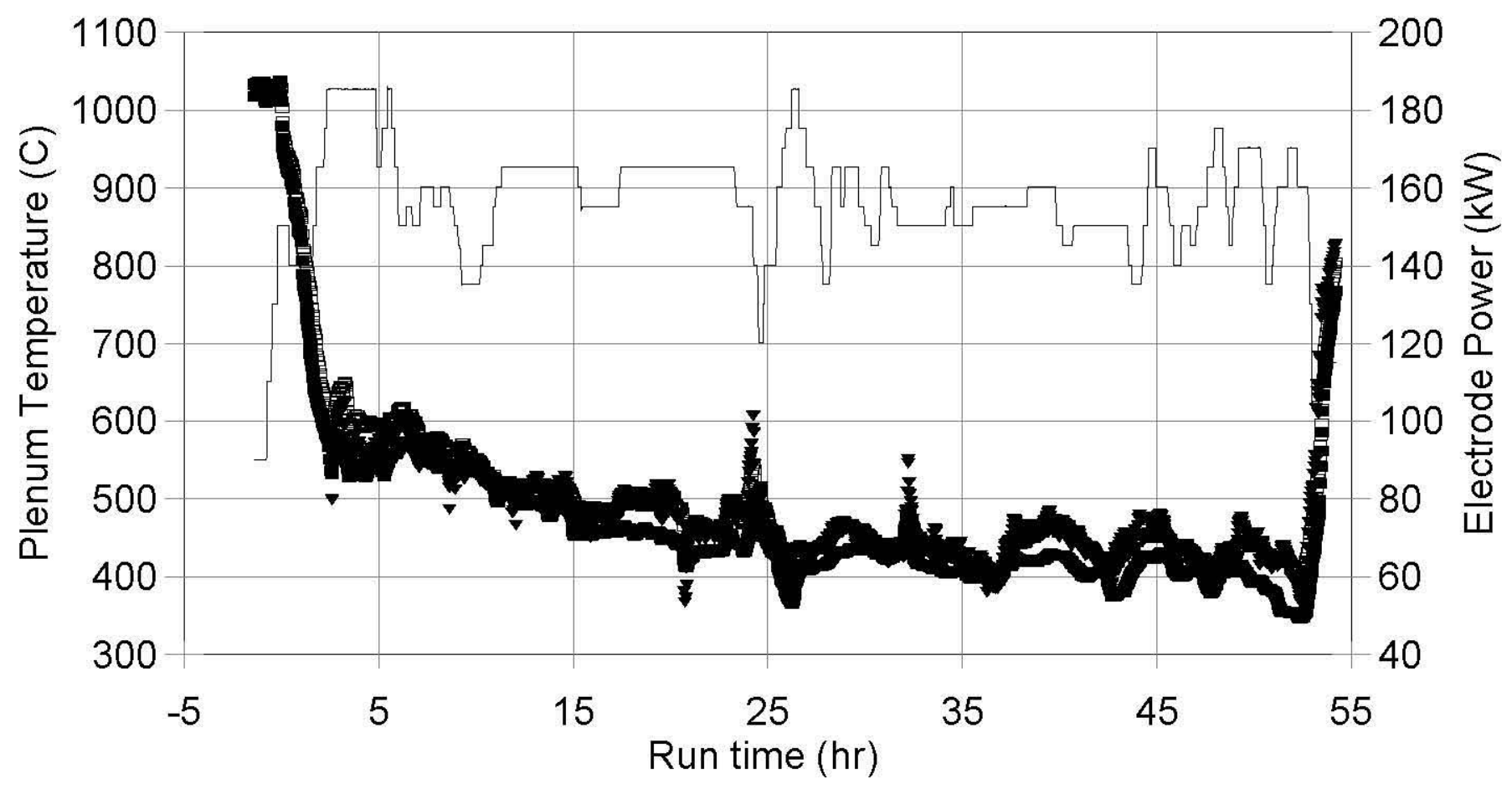

- 8 " below ceiling

- $17^{\prime \prime}$ below ceiling

- Exposed

Electrode power

Figure 3.9. Plenum temperatures and electrode power for DM1200 commissioning Test 3 (AZ-101 350 g/I with bubbling) 

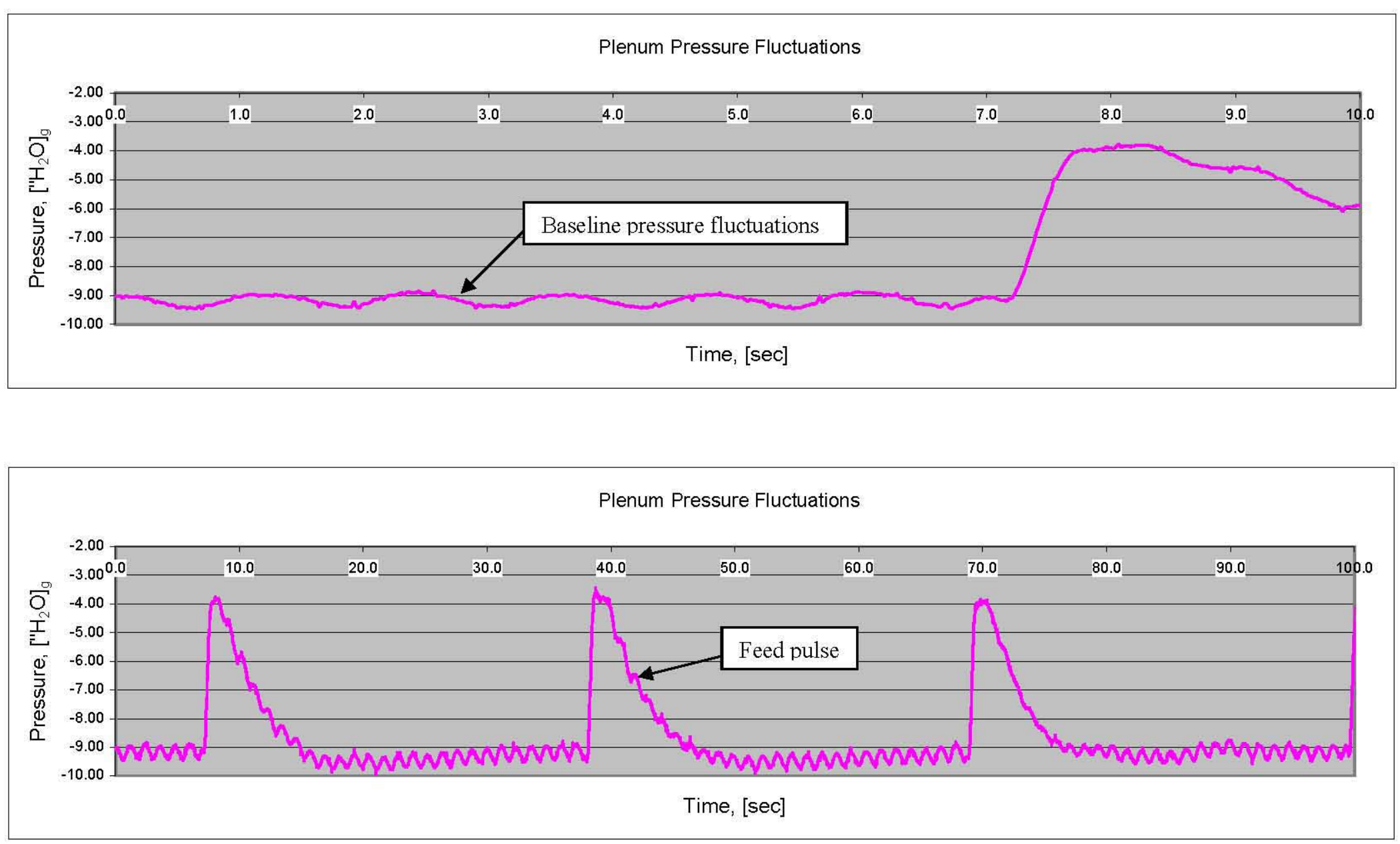

Figure 4.1. DM1200 plenum pressure measured with a fast response sensor $(5 \mathrm{~ms})$ showing pressure fluctuations due to feed pulses (upper plot represents a 10X time scale expansion of the first 10 seconds). Conditions: Start of Test 2; AZ-101 feed; average of $0.57 \mathrm{~kg}$ of feed per feed pulse; about $80 \%$ cold cap coverage. 

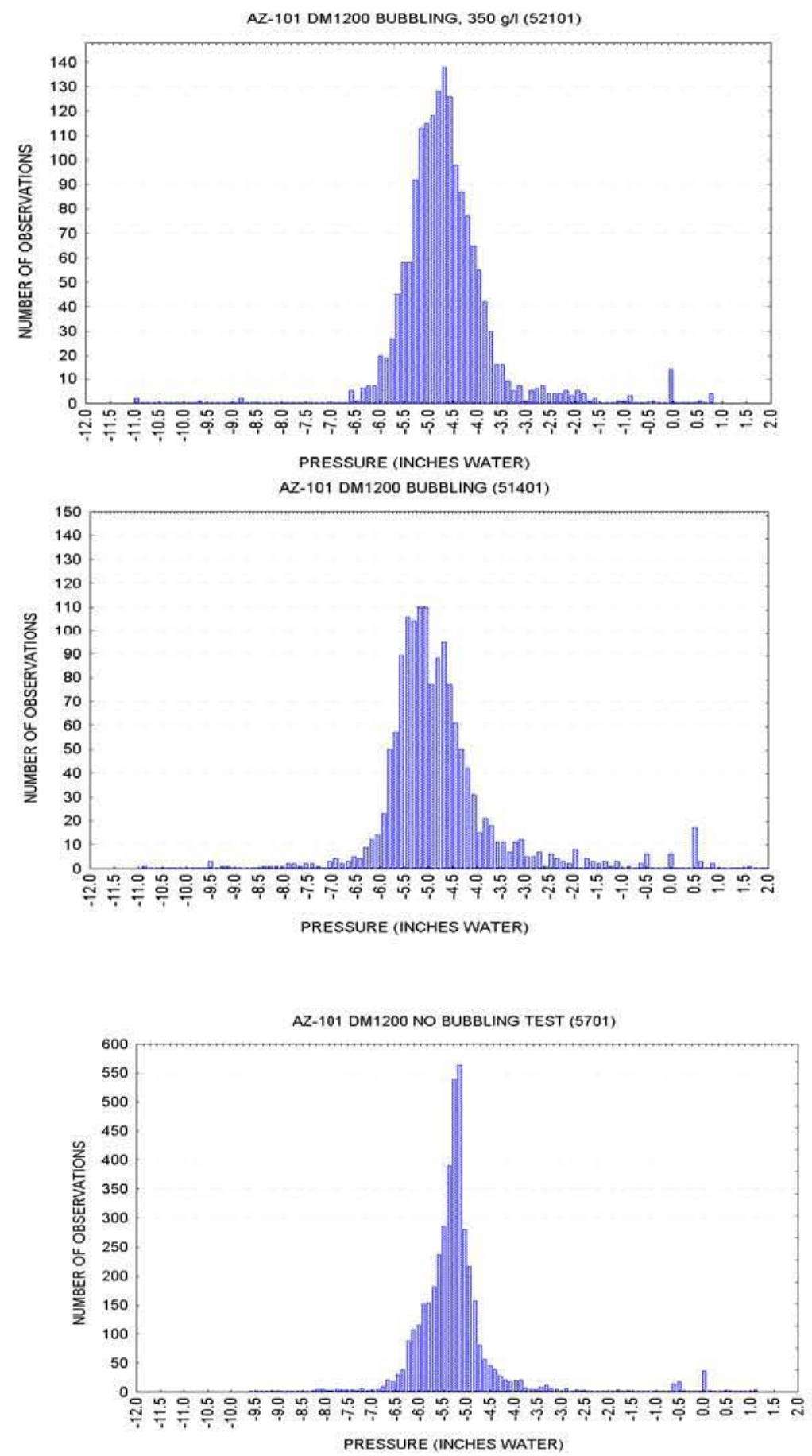

Figure 4.1a. Frequency distribution plots for melter pressure variations during Test 1 (bottom), Test 2 (middle), and Test 3 (top). 
TEST \#1 - MELTER PRESSURE

(as logged at 2 minute intervals)

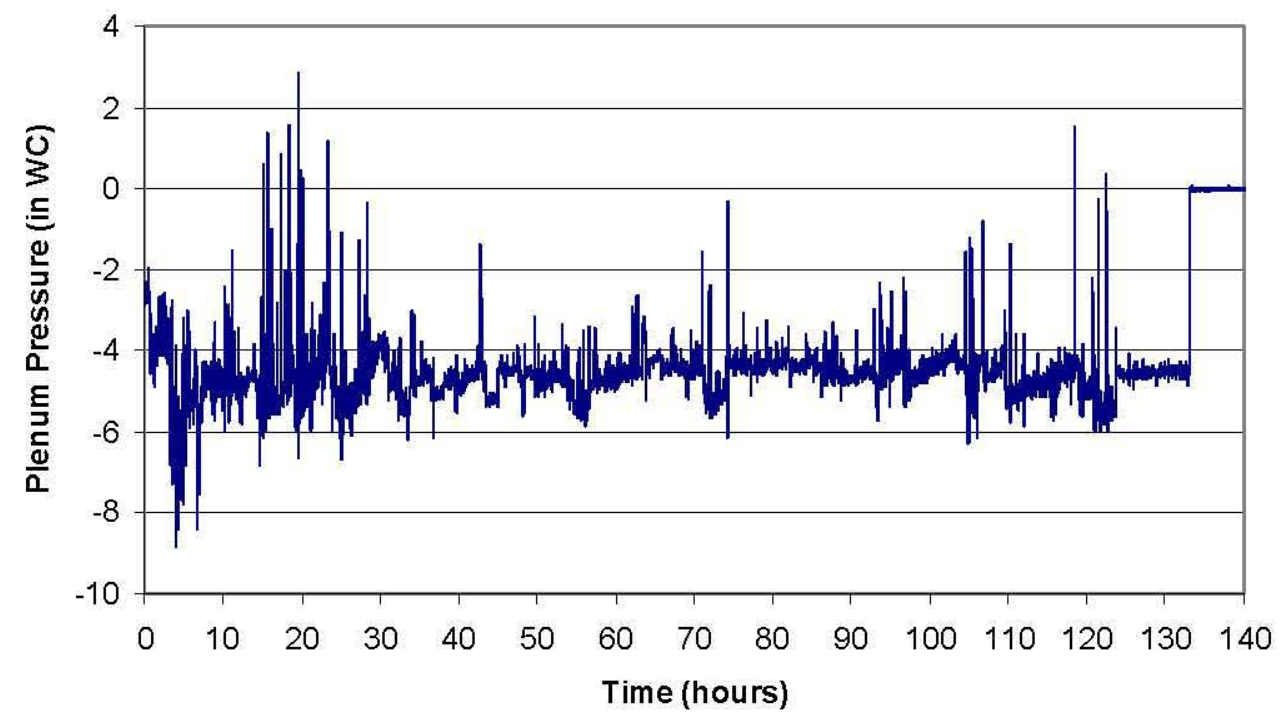

TEST \#1 - MELTER PRESSURE

(10 minute running average)

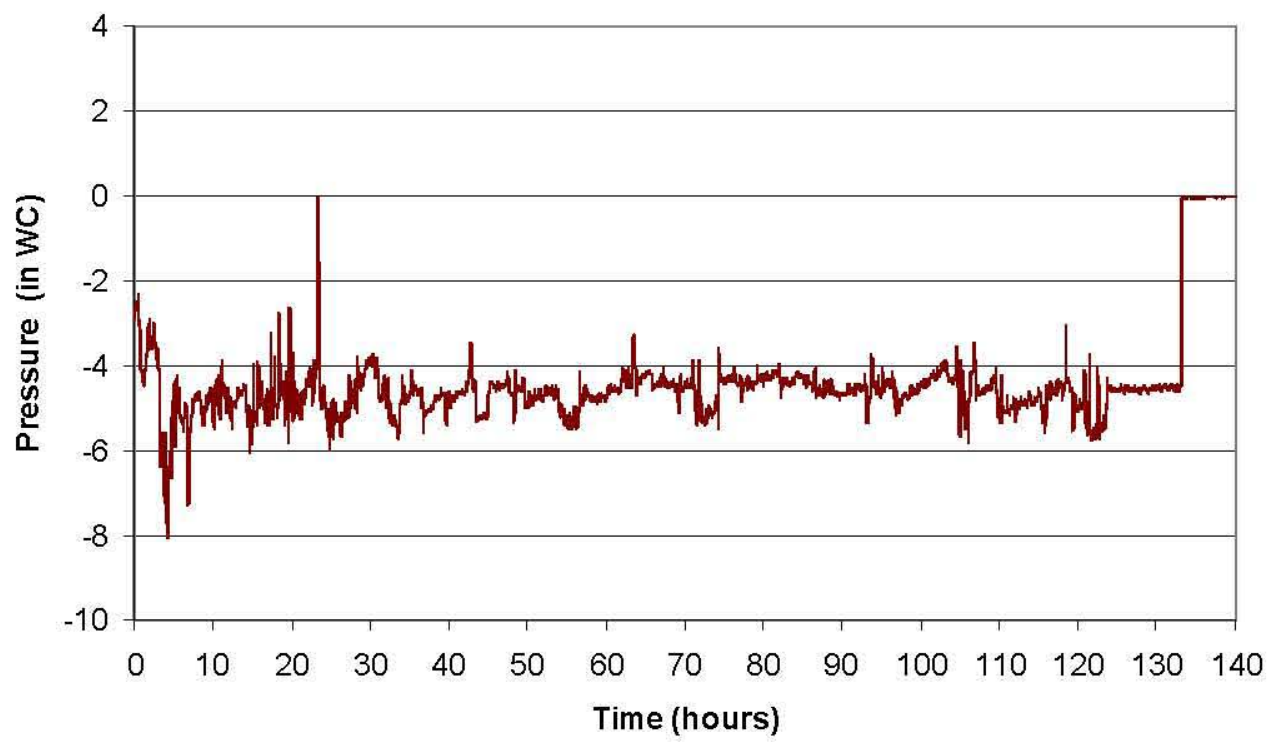

Figure 4.2. Melter pressure during Test $\# 1$ recorded at 2-minute intervals (top) and its moving average over 10 minutes period (i.e., every 5 measurements, bottom). 


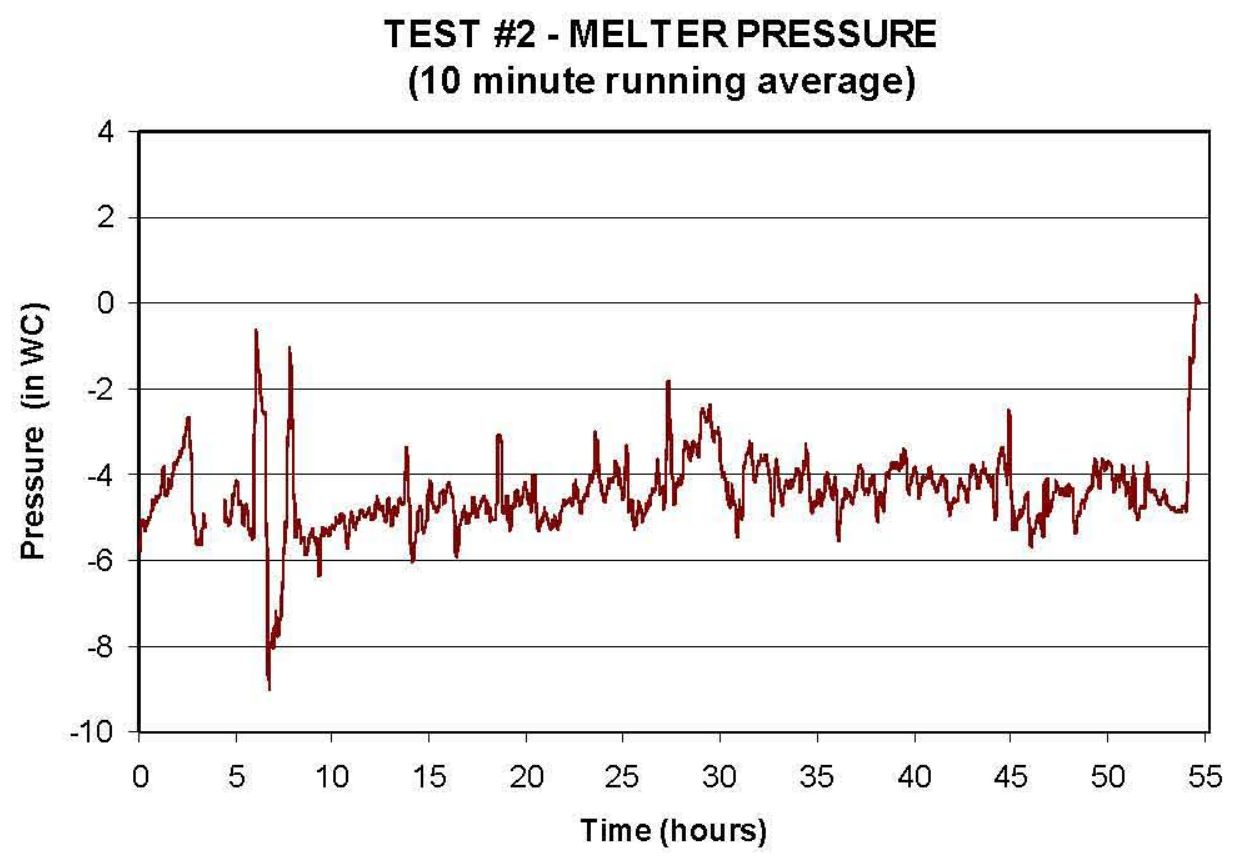

TEST \#3 - MELTER PRESSURE

(10 minute running average)

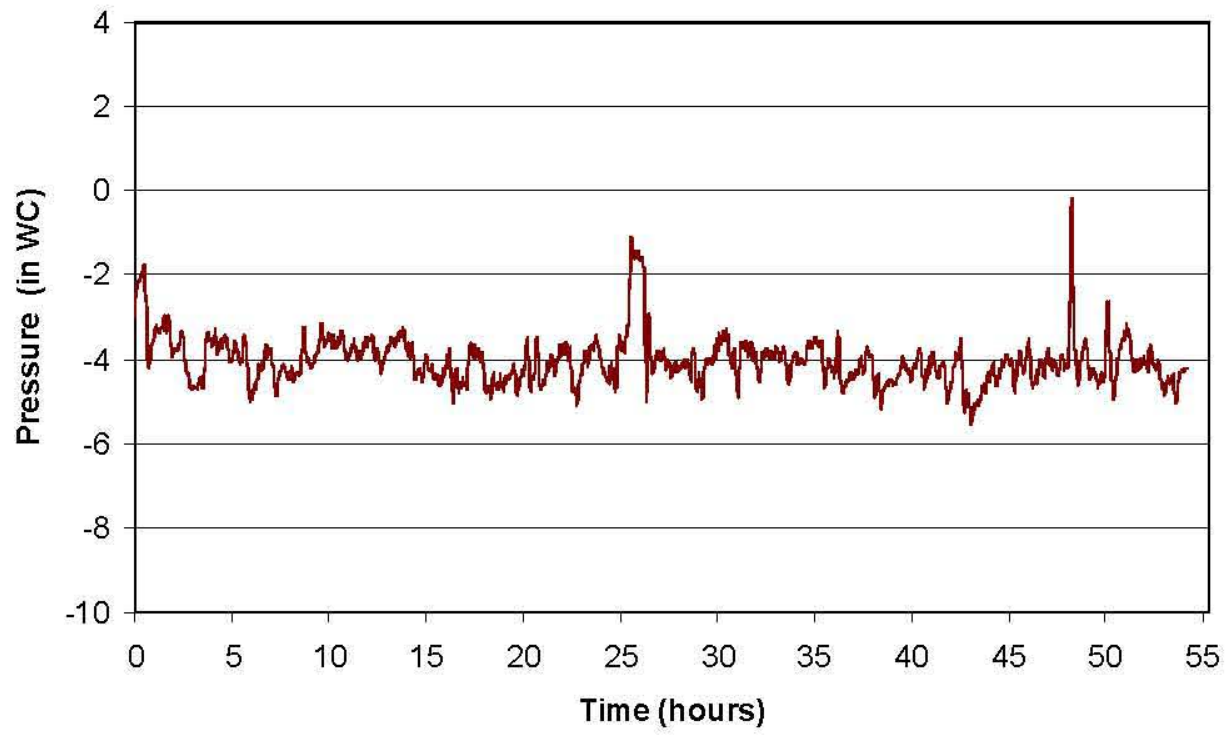

Figure 4.3. Ten minutes moving average of melter pressure during Test \#2 (top) and Test \#3 (bottom). 

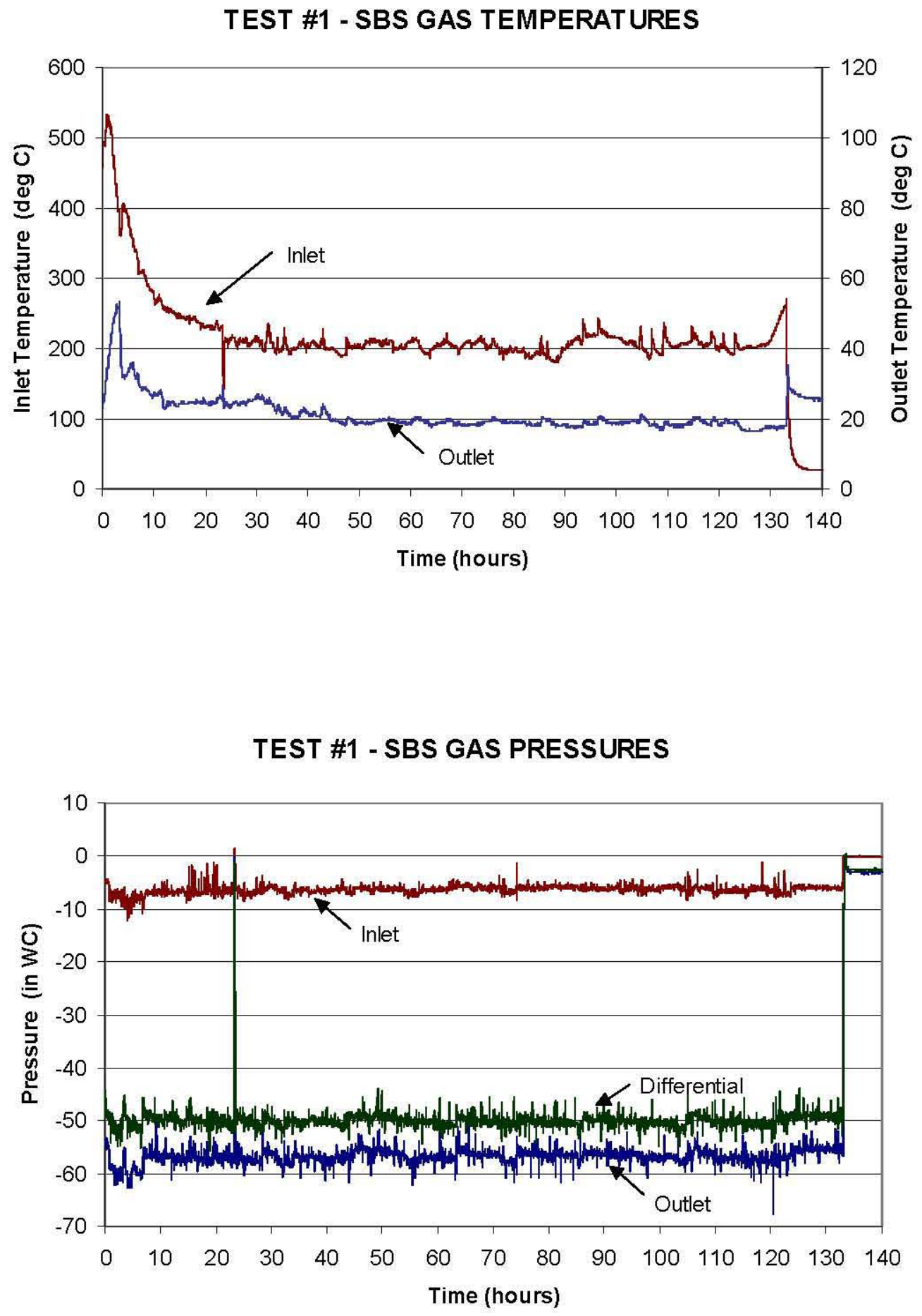

Figure 4.4. SBS inlet and outlet temperatures (top) and pressures (bottom) during Test \#1. 
TEST \#1 - SBS WATER TEMPERATURES
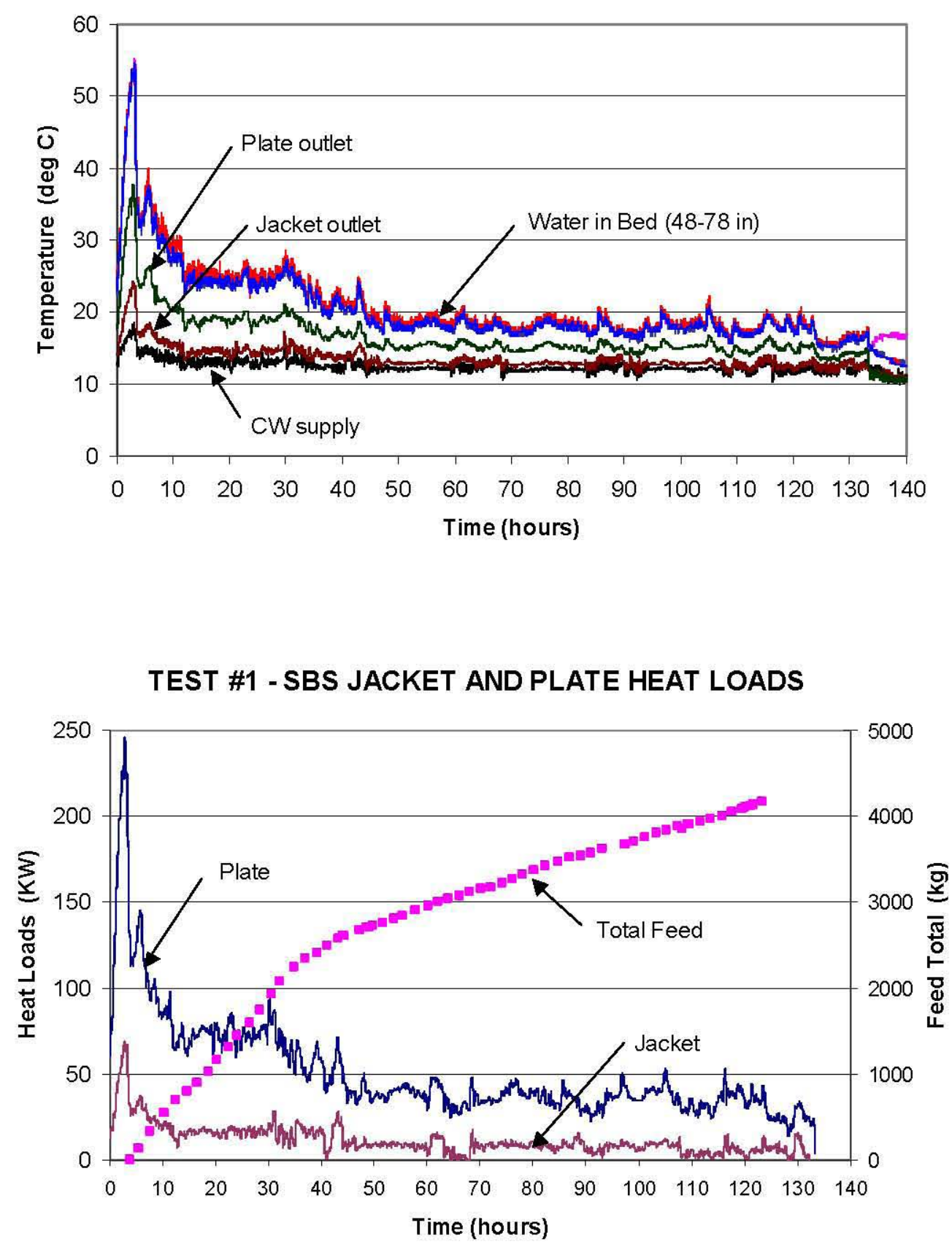

Figure 4.5. SBS cooling water temperatures and in-bed temperatures at depths of 48, 60, 72 and 78 inches (top) and heat removed by water jacket and plate heat exchanger (bottom)

for Test 1. Cumulative feed weight is also plotted aside heat loads. Plotted water temperatures and heat loads are 10 minutes moving averages. 


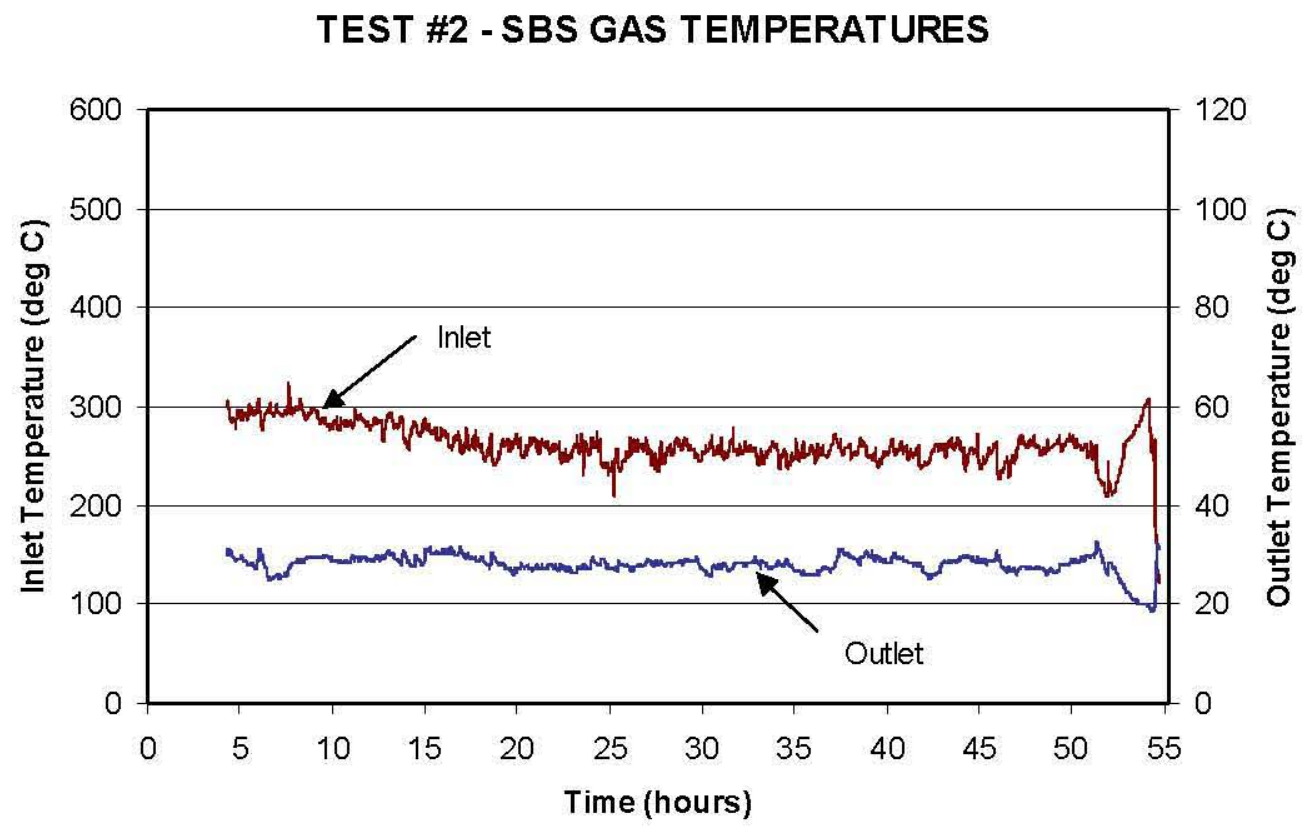

TEST \#2 - SBS GAS PRESSURES

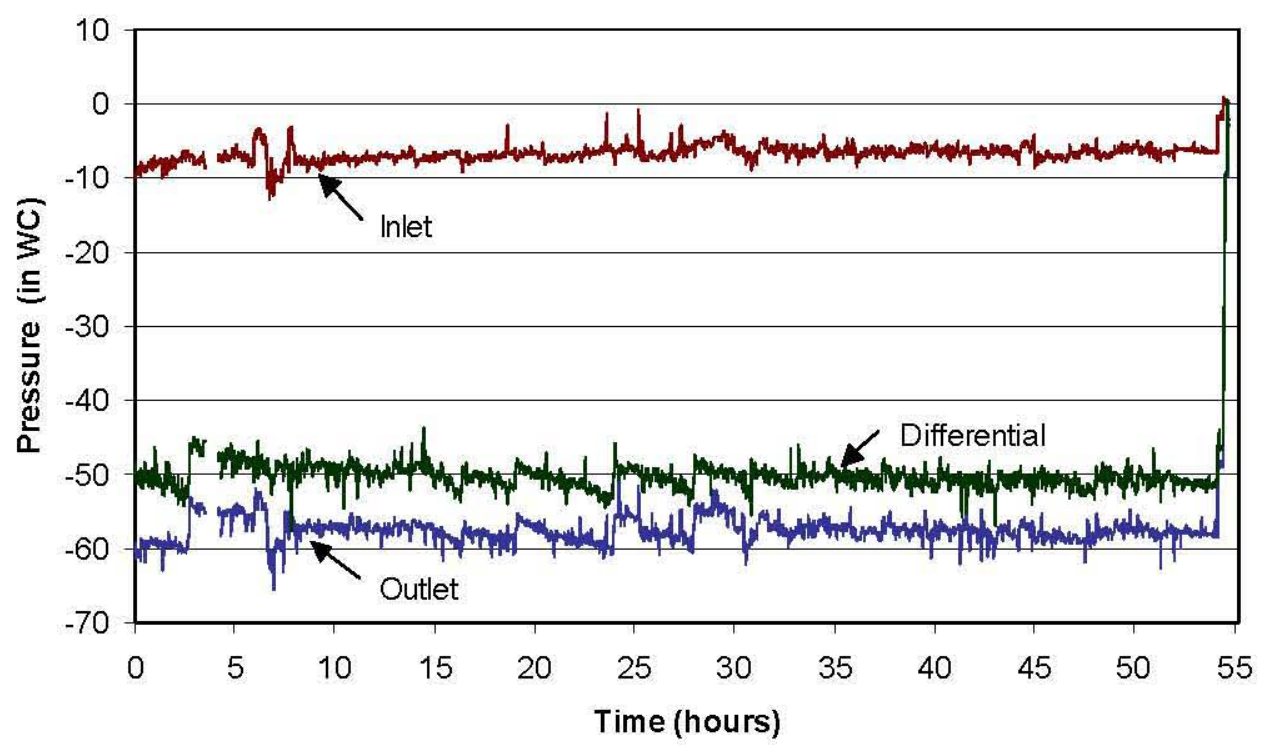

Figure 4.6. SBS inlet and outlet temperatures (top) and pressures (bottom) during Test 2. 
TEST \#2 - SBS WATER TEMPERATURES

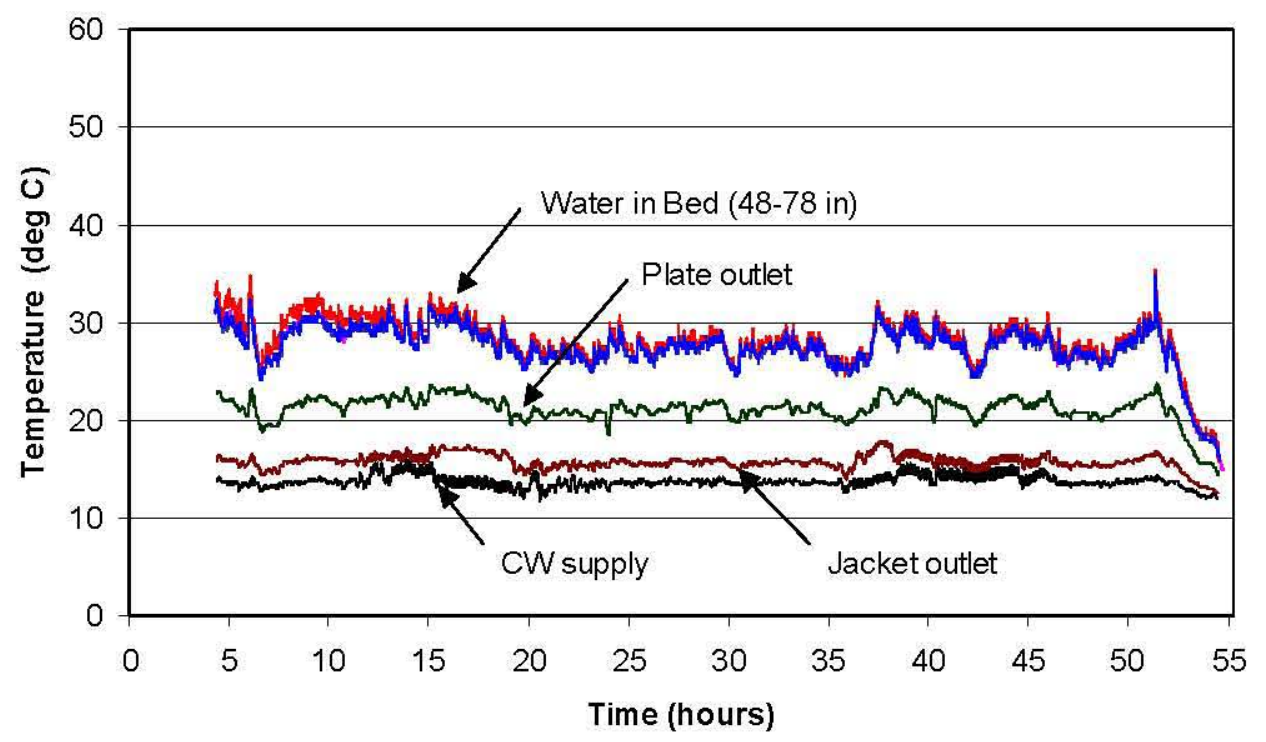

TEST \#2 - SBS JACKET AND PLATE HEAT LOADS

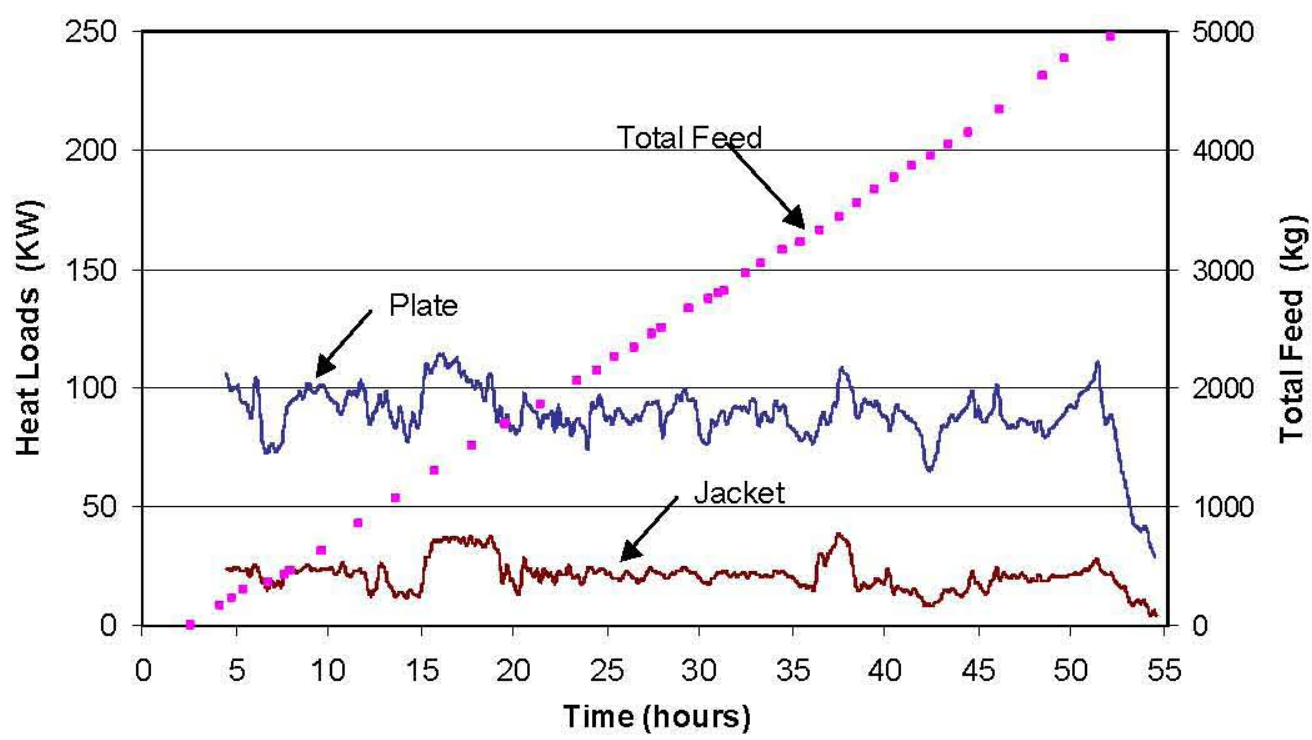

Figure 4.7. SBS cooling water temperatures and in-bed temperatures (top) and heat loads removed by water jacket and plate heat exchanger (bottom) for Test 2 . Cumulative feed weight is plotted along heat loads. Plotted water temperatures and heat loads are time averaged over 10 minutes (5 measurements). 
TEST \#3 - SBS GAS TEMPERATURES

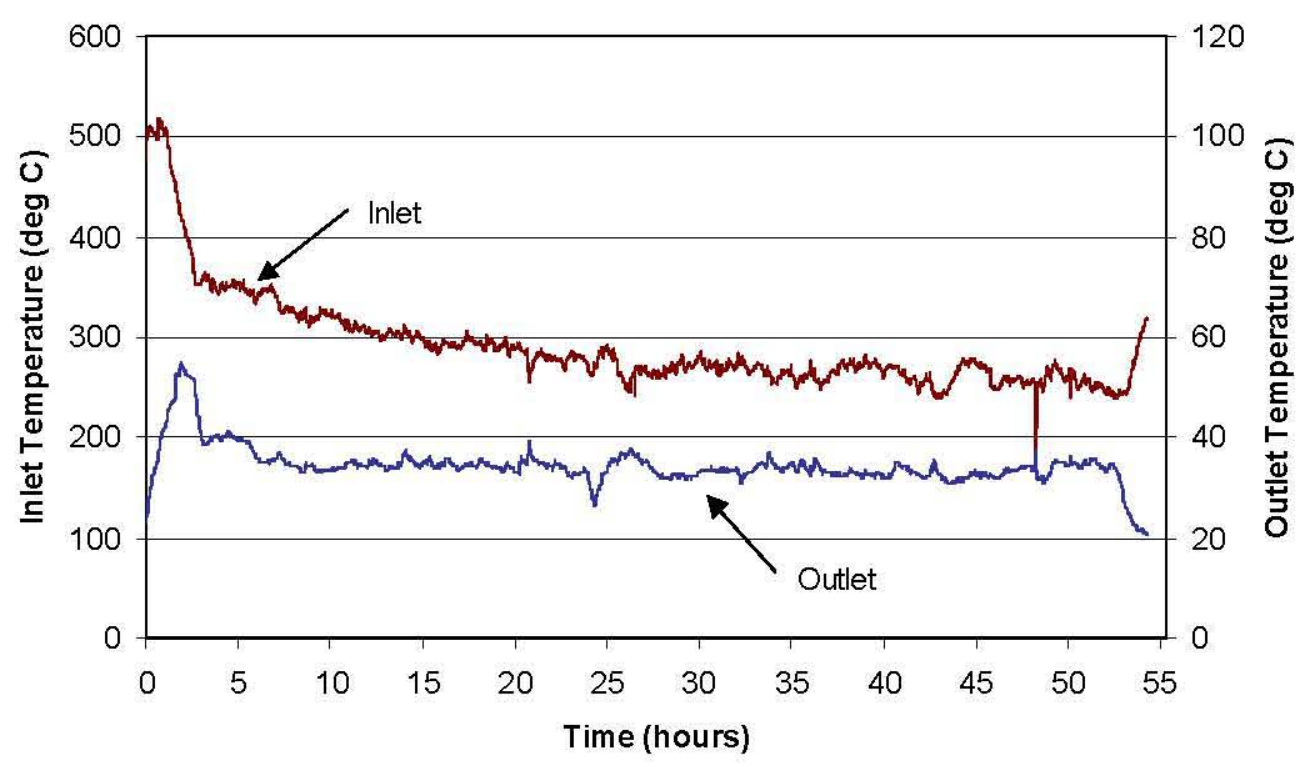

TEST \#3 - SBS GAS PRESSURES

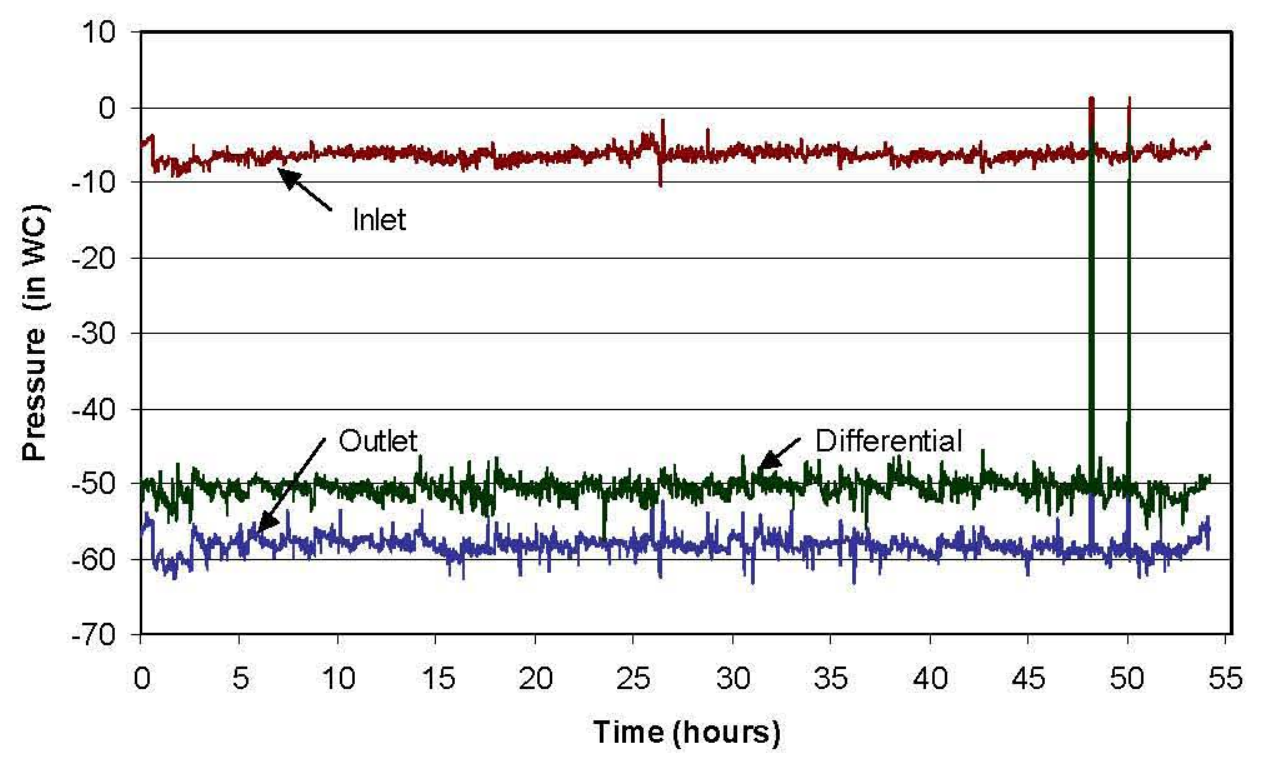

Figure 4.8. SBS inlet and outlet temperatures (top) and pressures (bottom) during Test 3. 


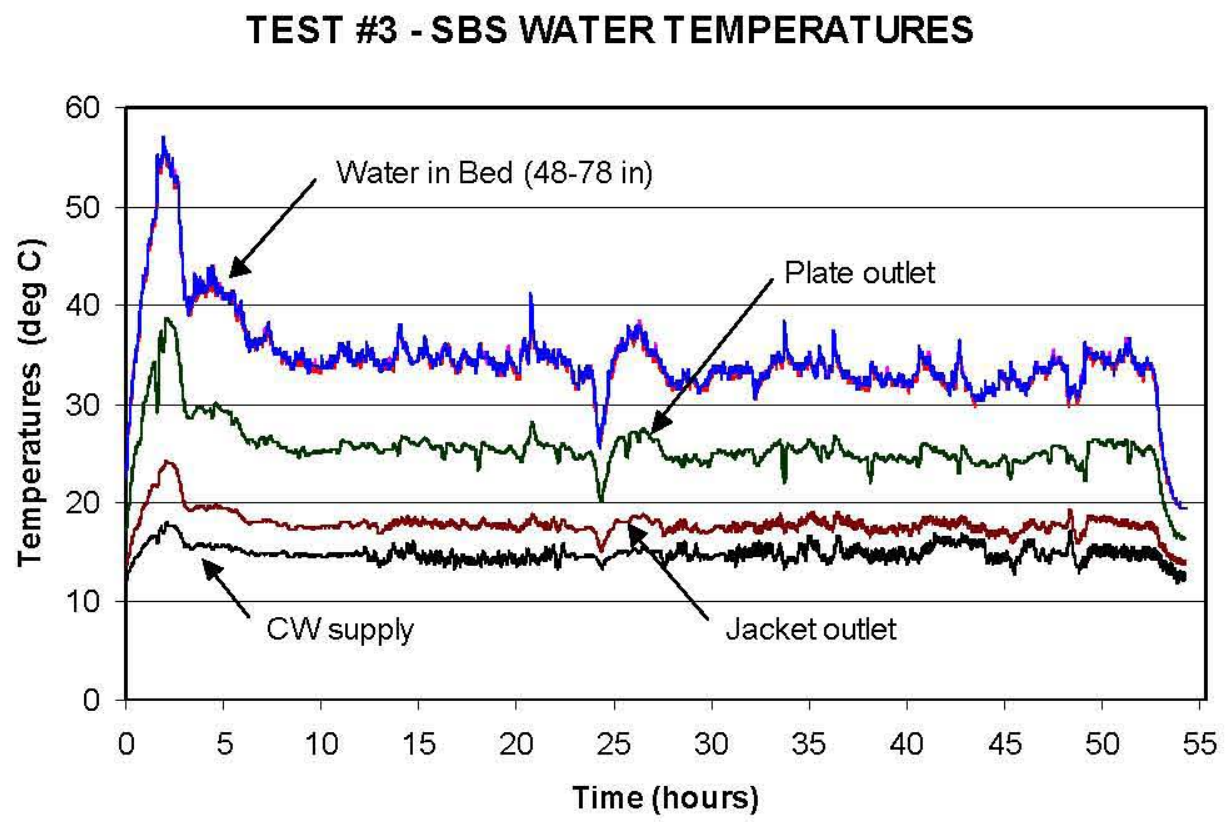

TEST \#3 - SBS JACKET AND PLATE HEAT LOADS

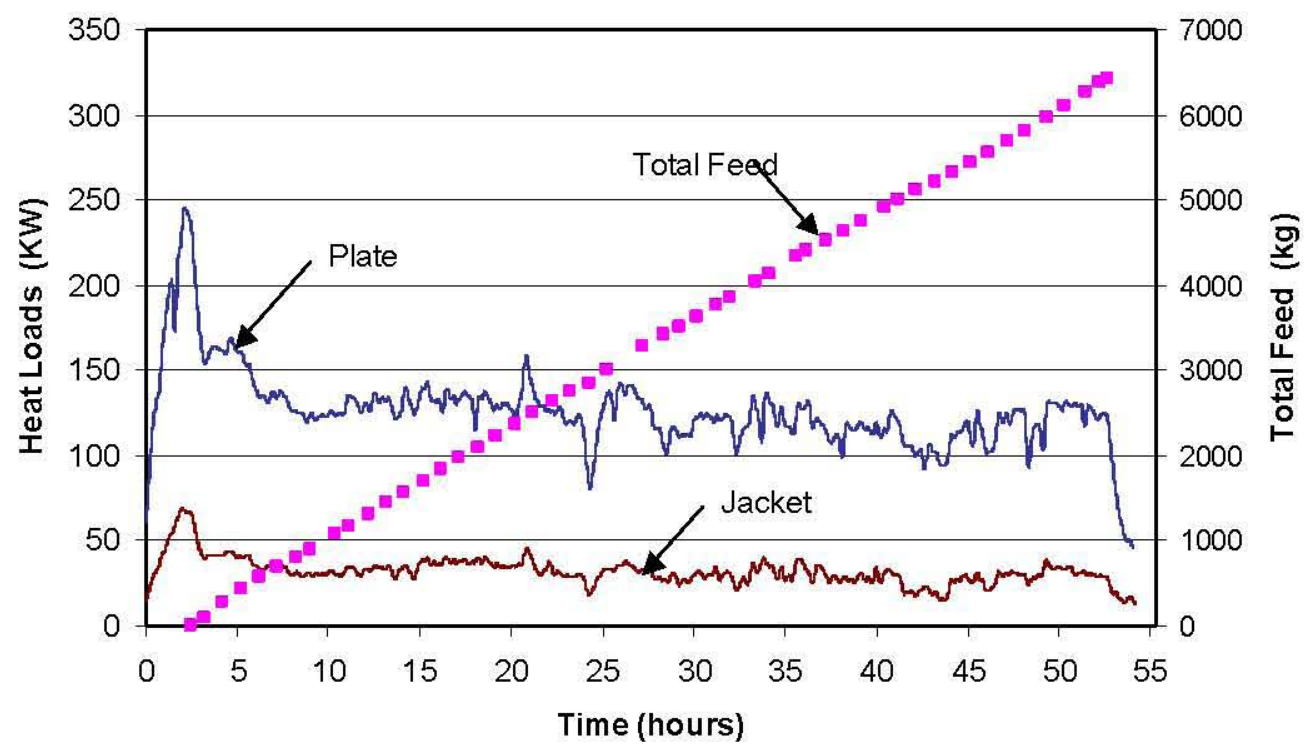

Figure 4.9. SBS cooling water temperatures and in-bed temperatures at depths of 48, 60, 72 and 78 inches (above) and heat removed by water jacket and plate heat exchanger (below)

for Test 3. Cumulative feed weight is also plotted aside heat loads. Plotted water temperatures and heat loads are 10 minutes moving averages. 

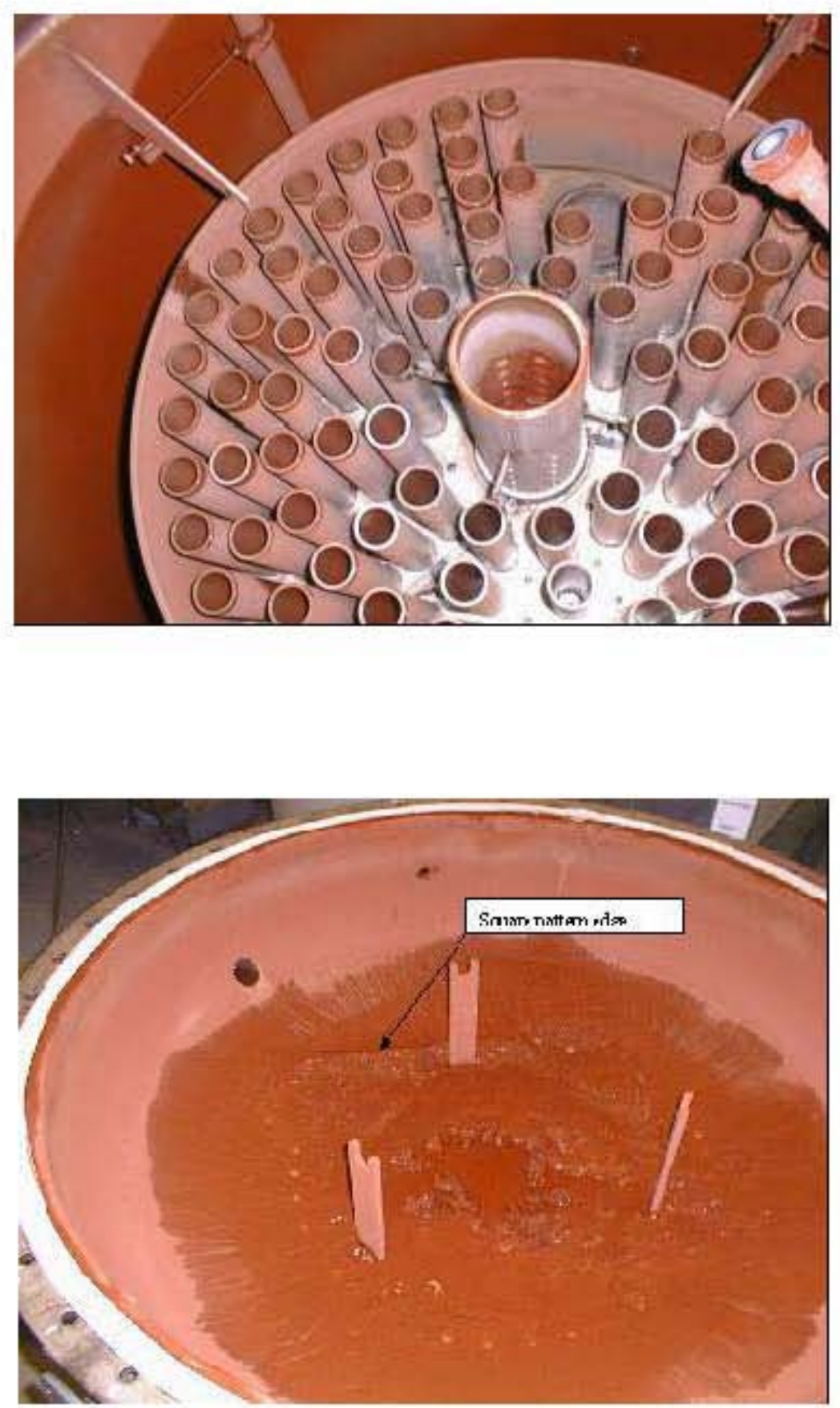

Figure 4.10. Upward view showing downcomer extension, weir tubes and diffuser plate (top) and deposits on the SBS bottom dish at the conclusion of the commissioning tests (bott om). 


\section{TEST \#1 - WESP GAS TEMPERATURES AND PRESSURE}

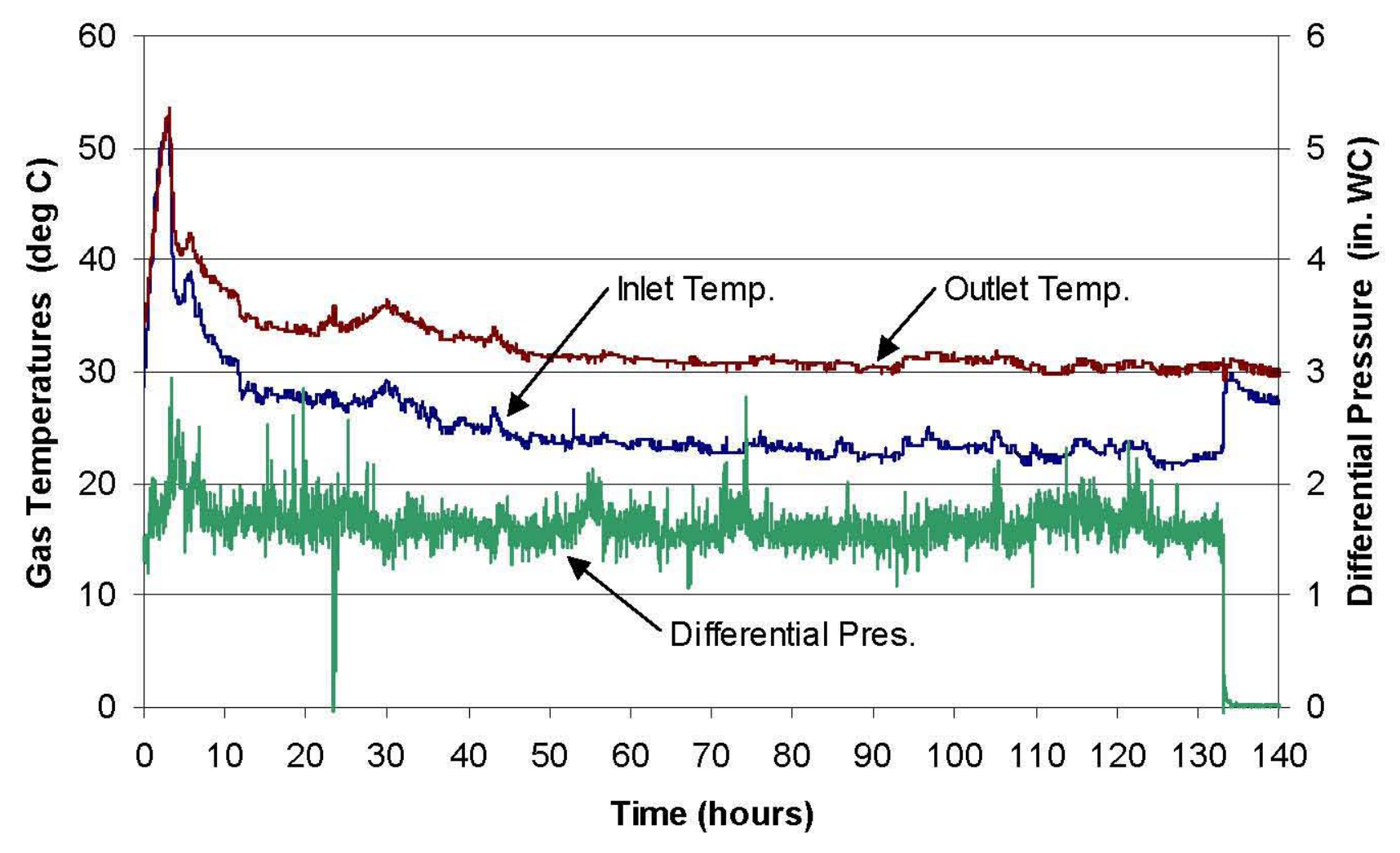

Figure 4.11. WESP inlet and outlet temperatures and differential pressure across the WESP during Test 1. 


\section{TEST \#2 - WESP GAS TEMPERATURES AND PRESSURE}

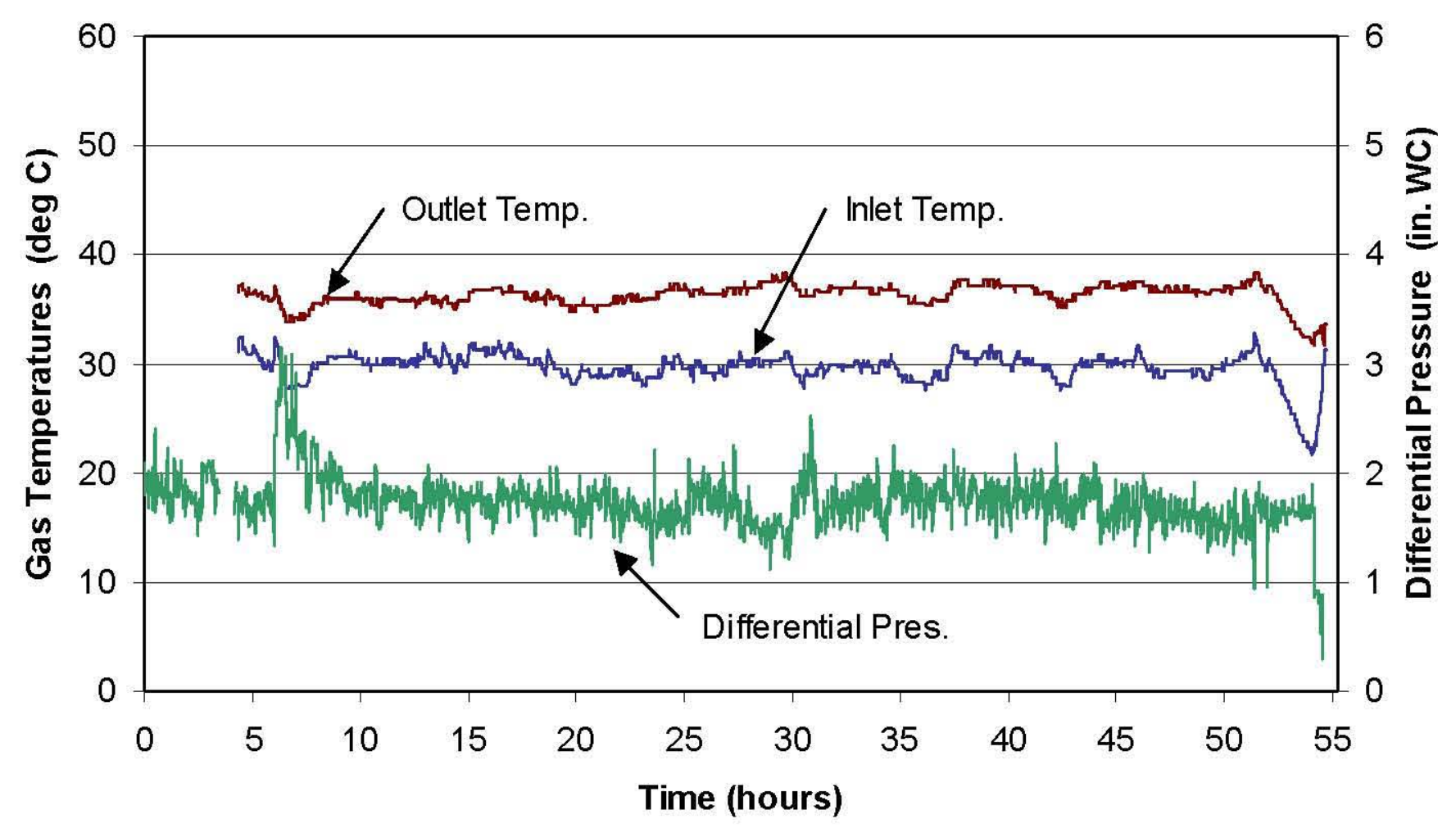

Figure 4.12. WESP inlet and outlet temperatures and differential pressure across the WESP during Test 2. 


\section{TEST \#3 - WESP GAS TEMPERATURES AND PRESSURE}

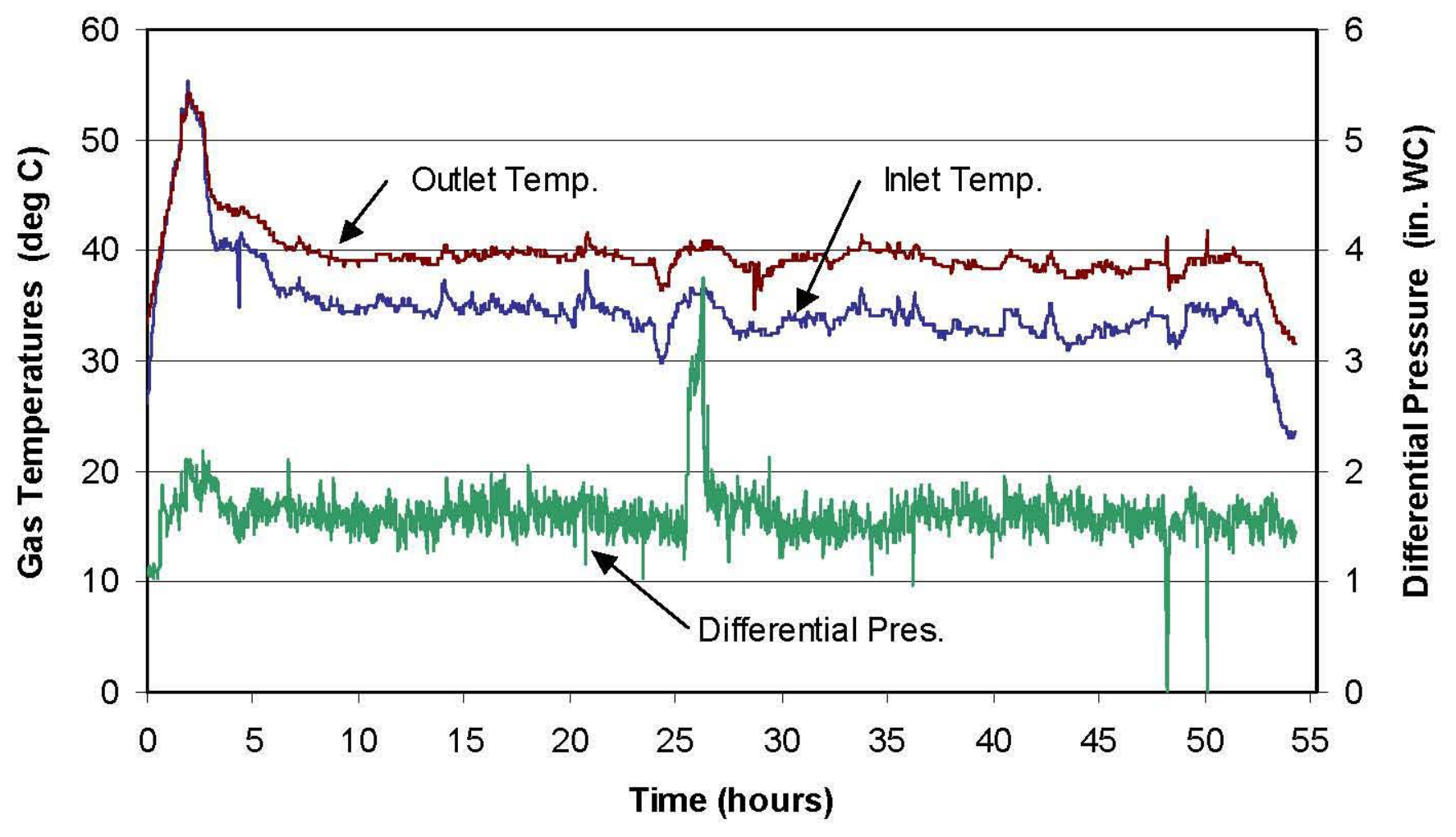

Figure 4.13. WESP inlet and outlet temperatures and differential pressure across the WESP during Test 3. 

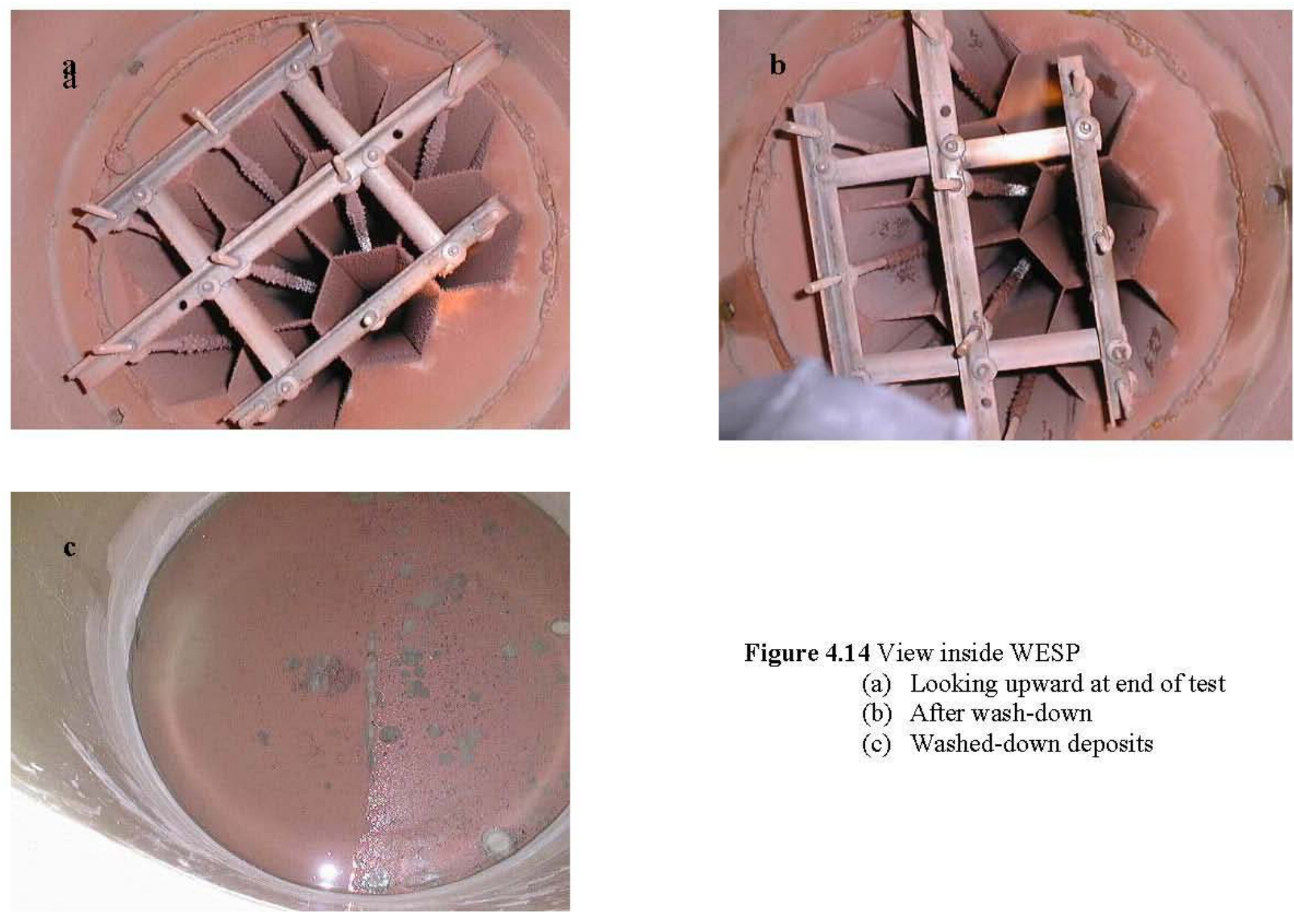

Figure 4.14 View inside WESP

(a) Looking upward at end of test

(b) After wash-down

(c) Washed-down deposits 


\section{TEST \#1 - HEPA\#1 GAS TEMPERATURE AND PRESSURE}

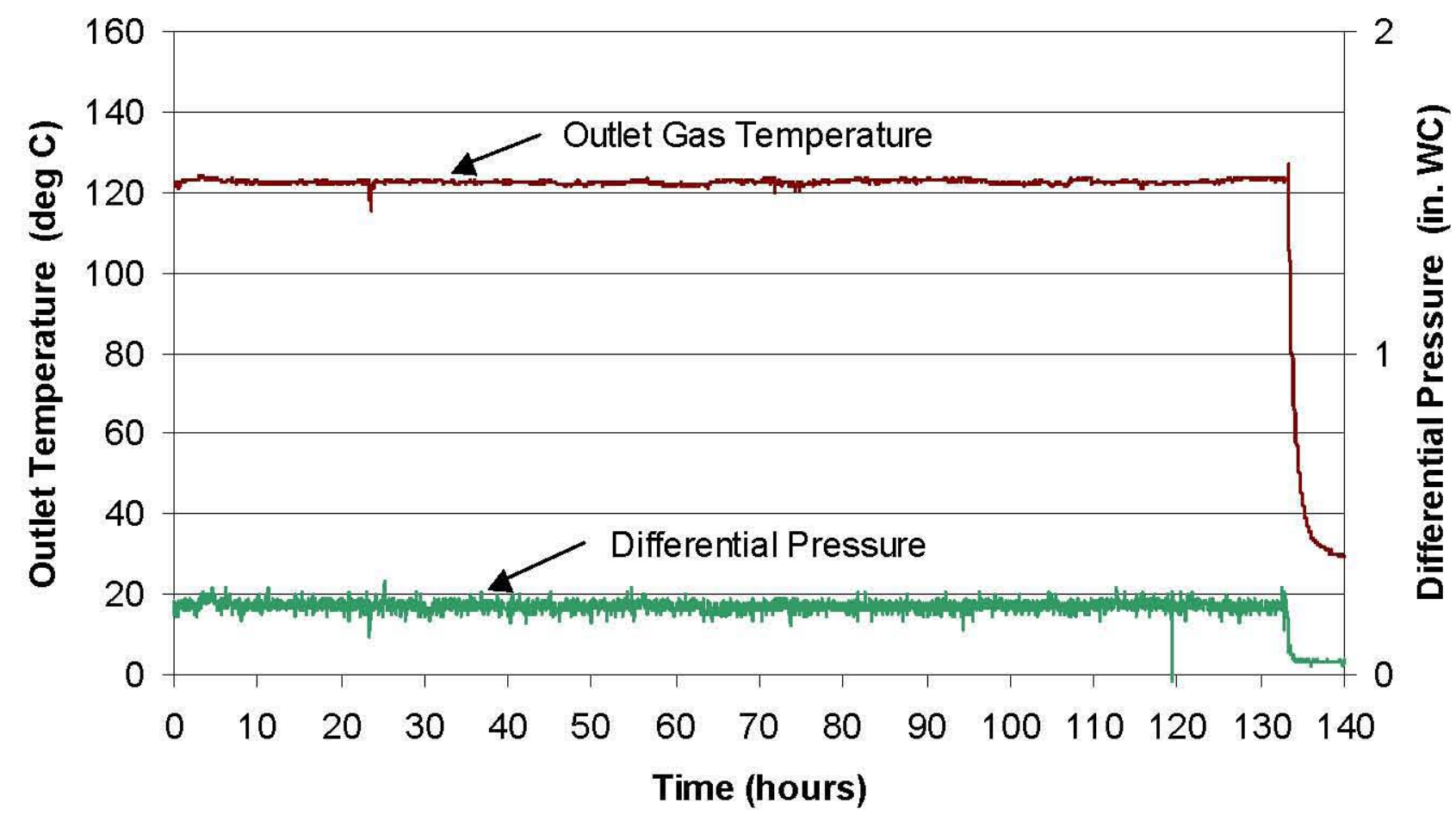

Figure 4.15. Outlet temperature and differential pressure for HEPA \#1 during Test 1. 


\section{TEST \#2 - HEPA \#1 GAS TEMPERATURE AND PRESSURE}

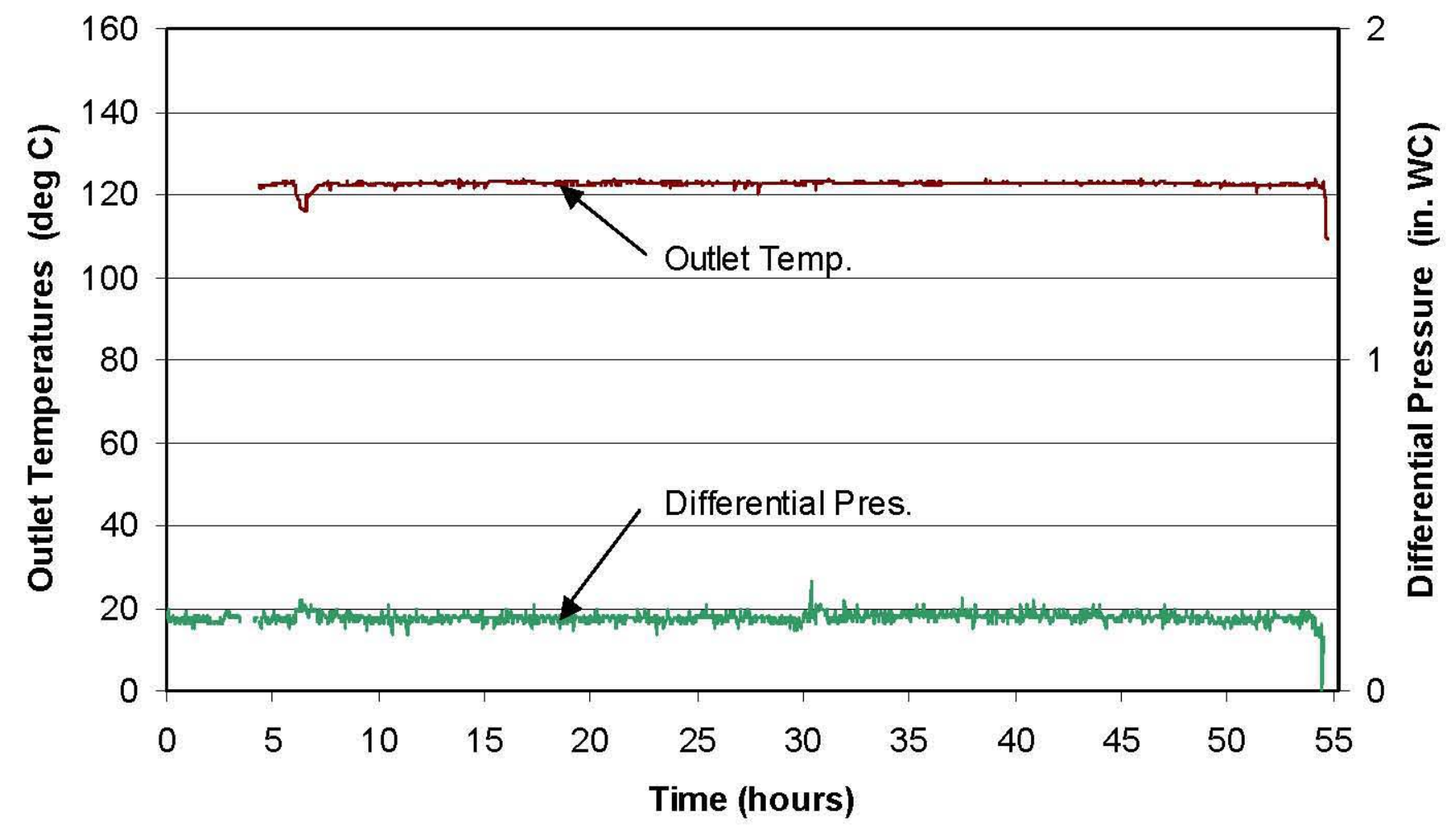

Figure 4.16. Outlet temperature and differential pressure for HEPA \#1 during Test 2. 


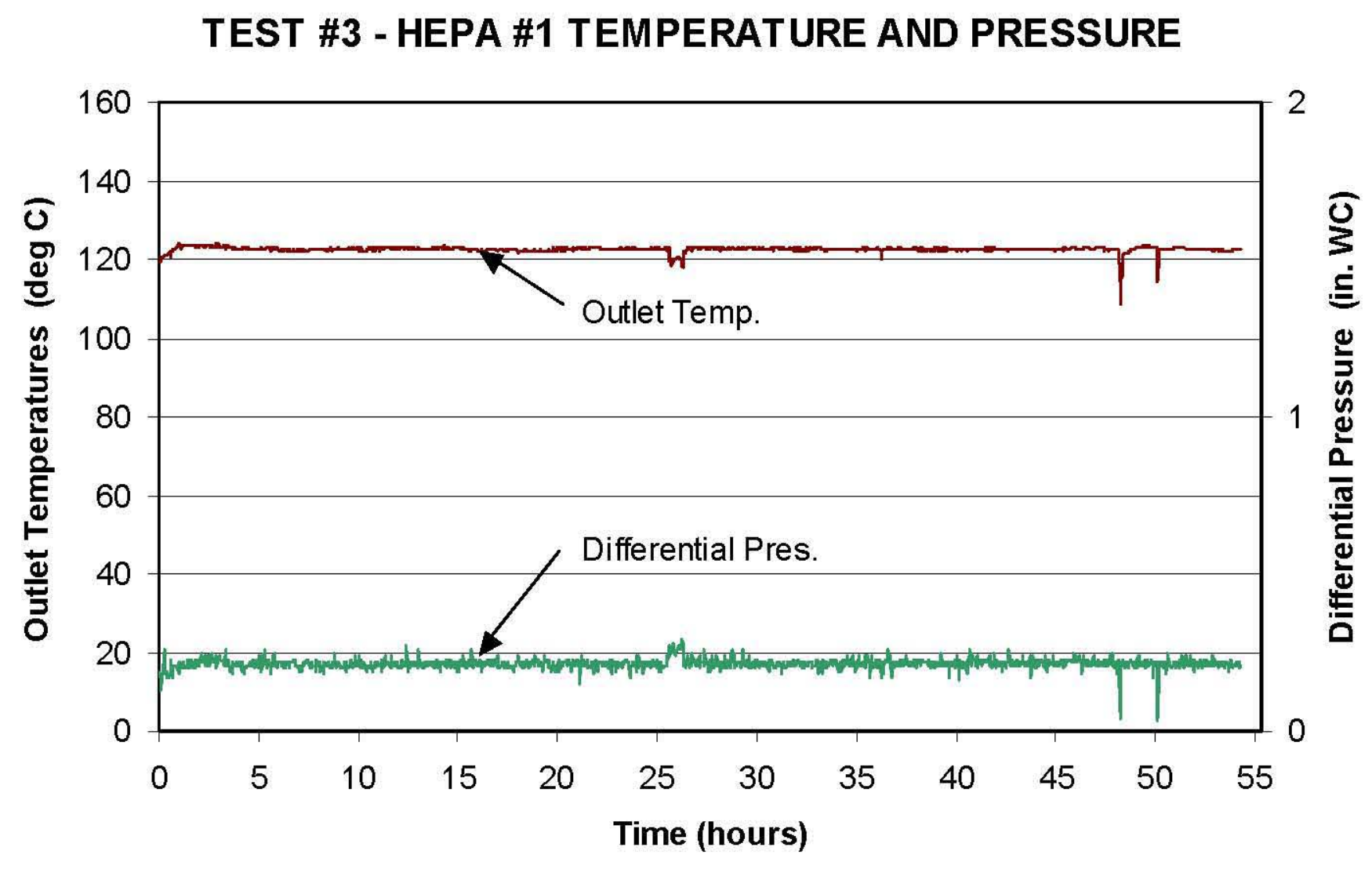

Figure 4.17. Outlet temperature and differential pressure for HEPA \#1 during Test 3. 
TEST \#1 - CAUSTIC SCRUBBER AND NEUTRALIZATION TANK

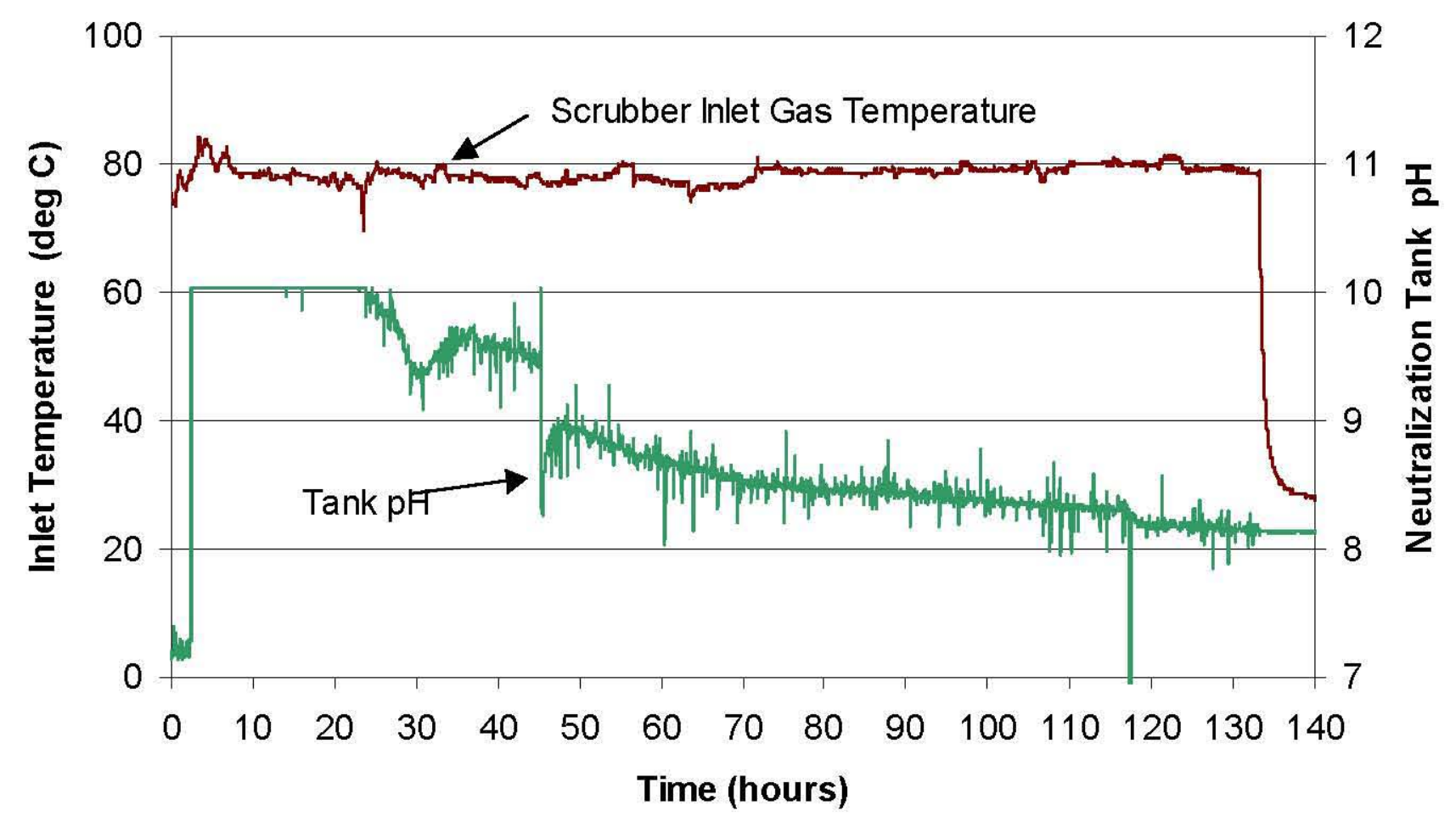

Figure 4.18. PBS inlet gas temperature and neutralization tank pH during Test 1. 


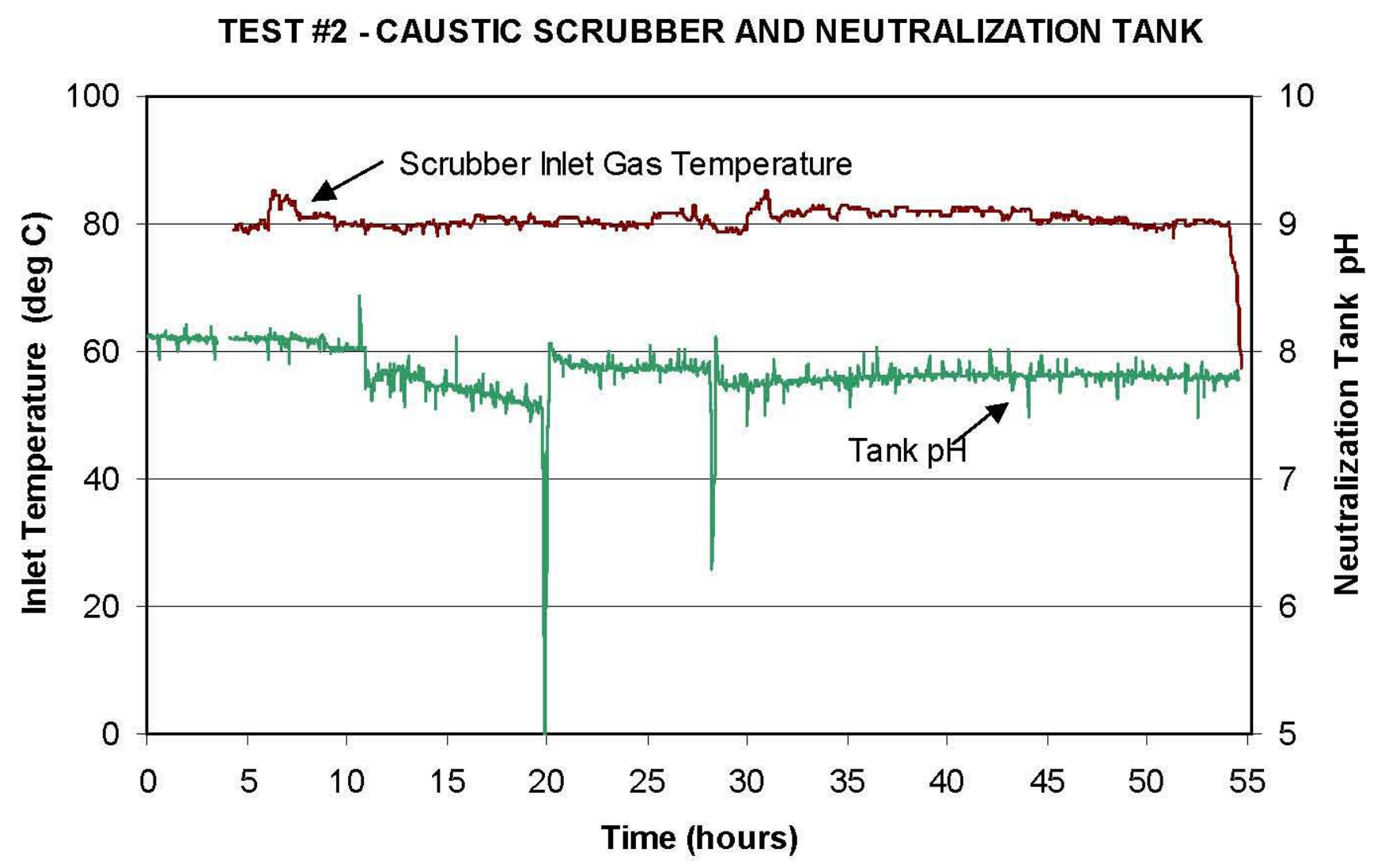

Figure 4.19. PBS inlet gas temperature and neutralization tank pH during Test 2. 
TEST \#3 - CAUSTIC SCRUBBER AND NEUTRALIZATION TANK

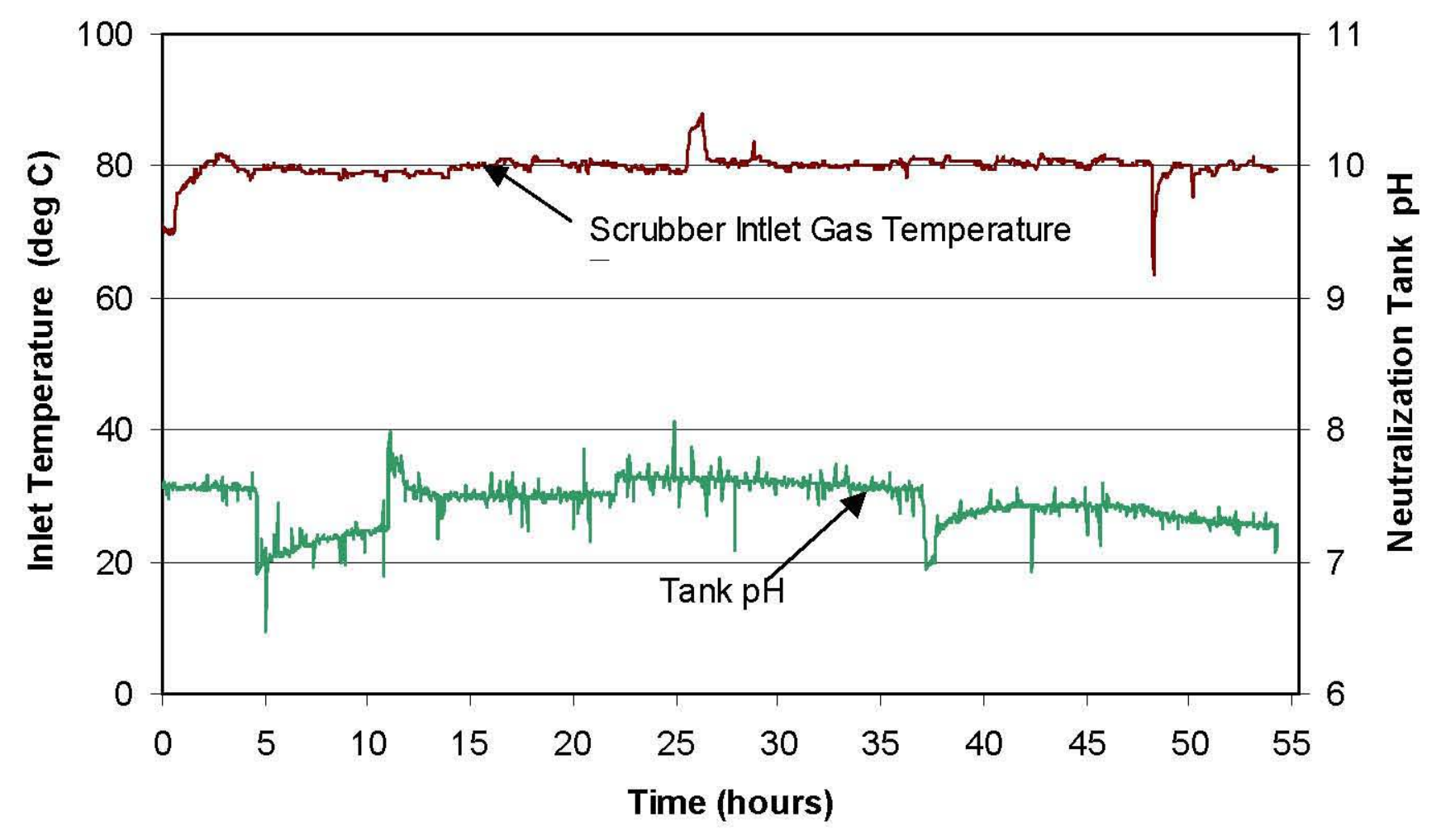

Figure 4.20. PBS inlet gas temperature and neutralization tank pH during Test 3. 
ORP-51437, Rev. 0

DuraMelter 1200 Start-Up

Final Report, VSL-

TEST \#1 - TCO OUTLET GAS TEMPERATURE

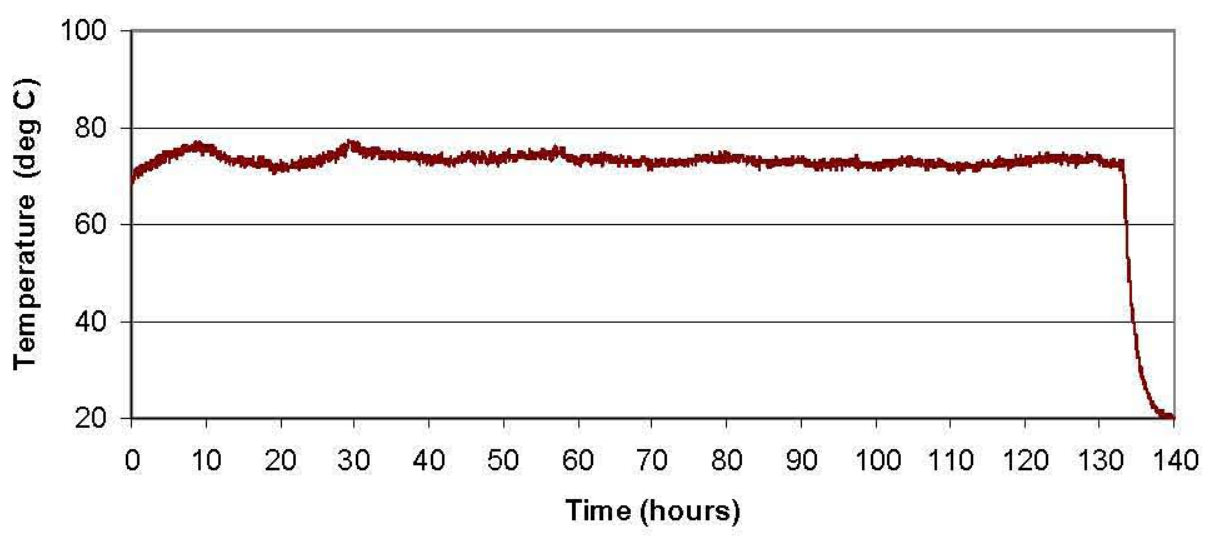

TEST \#2 - TCO OUTLET GAS TEMPERATURE

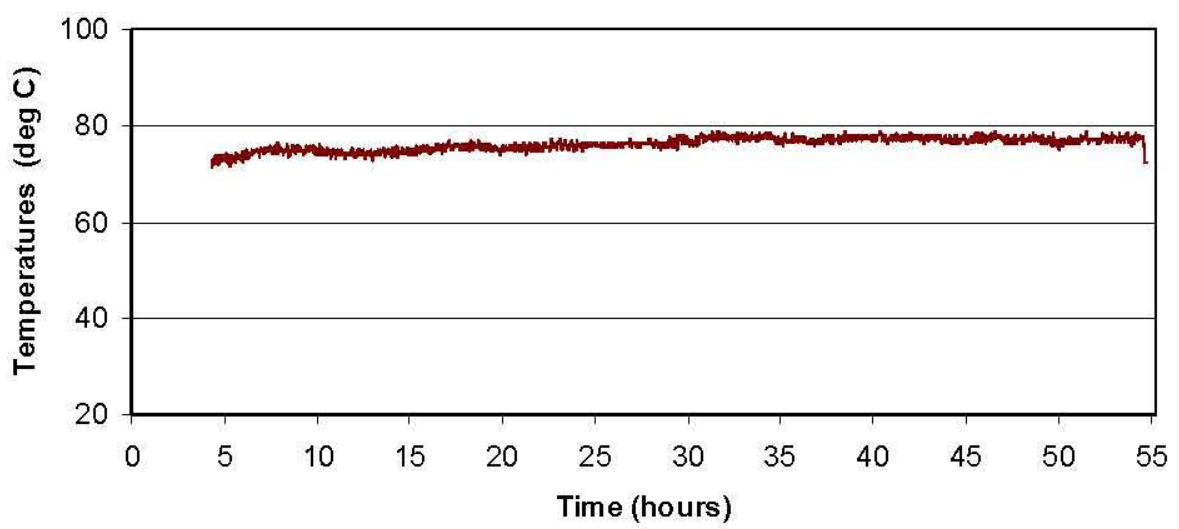

TEST \#3 - TCO OUTLET GAS TEMPERATURE

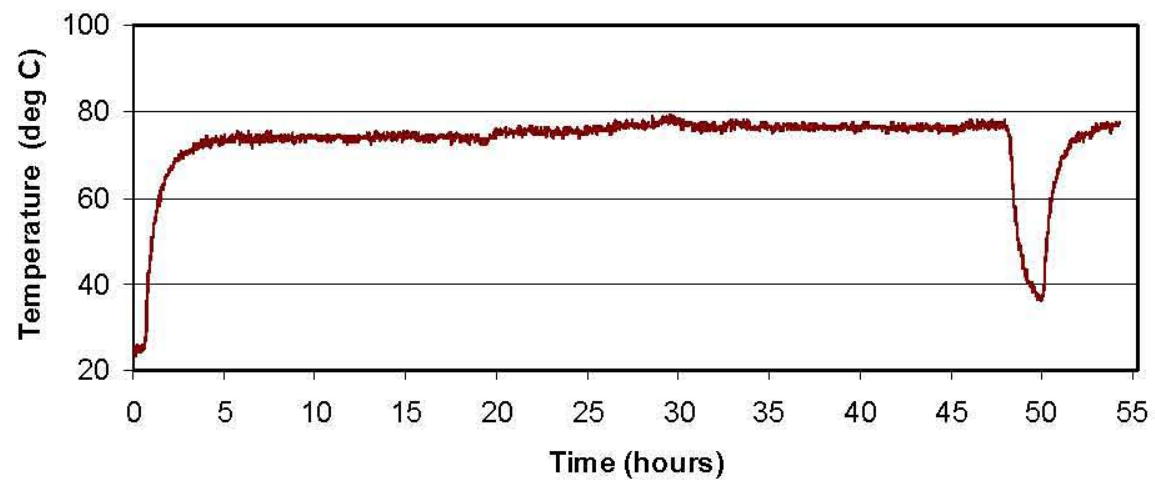

Figure 4.21. Thermal catalytic oxidation (TCO) unit gas outlet temperature. 


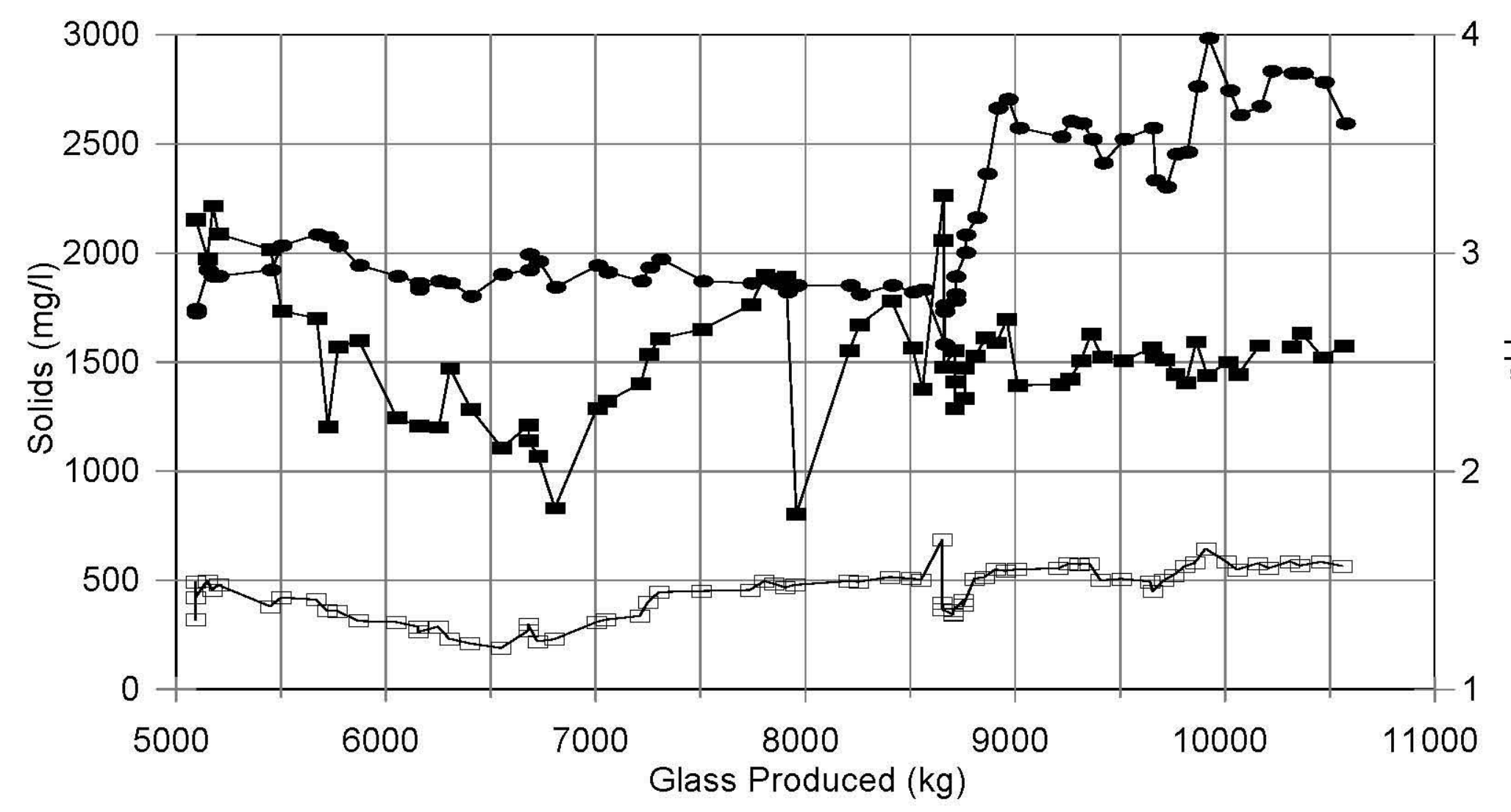

증

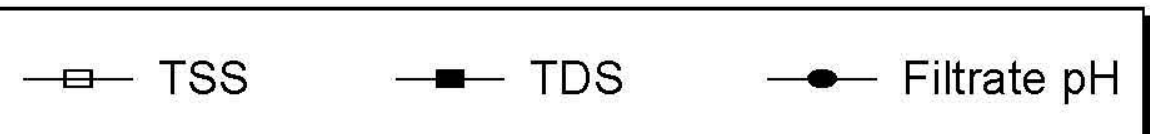

Figure 4.22. Total suspended and dissolved solids contents and pH of SBS liquids from post-turnover tests. 


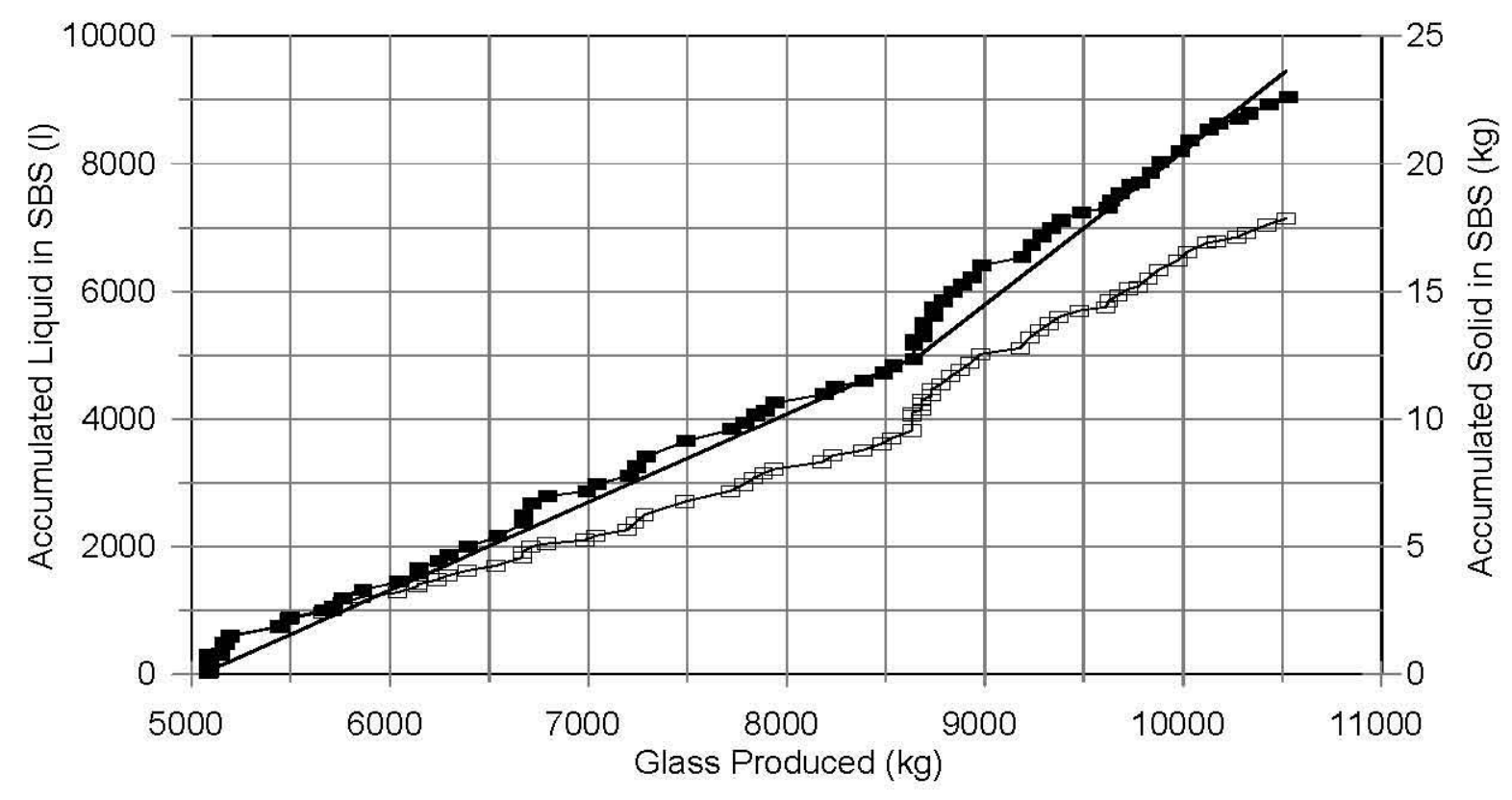

Figure 4.23. Total solids and liquids accumulations in the SBS (including blowdowns) during post-turnover DM1200 commissioning tests. 
The Catholic University of America

Vitreous State Laboratory

\section{Suspended}

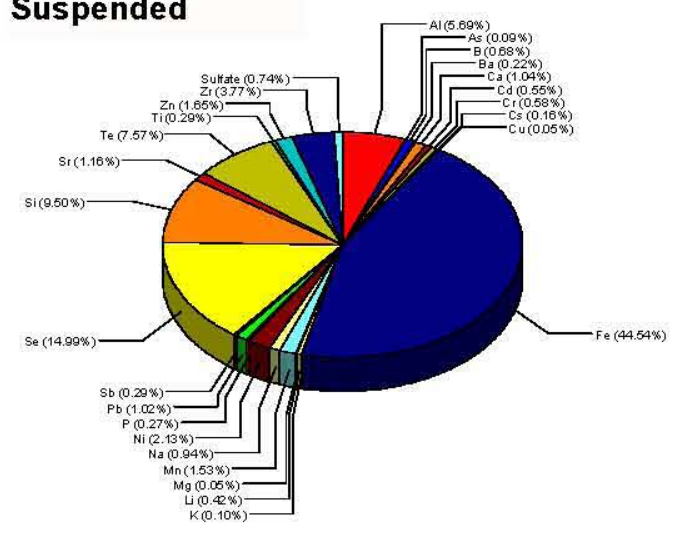

Feed

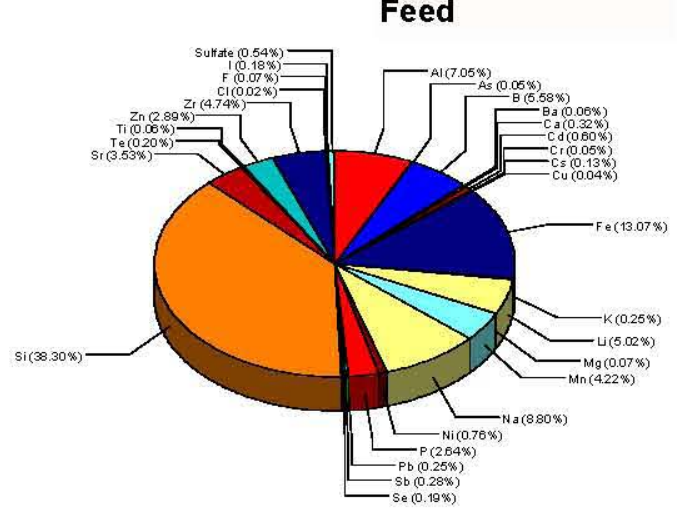

DuraMelter 1200 Start-Up Tests with AZ-101 Final Report, VSL-01R0100-2, Rev.0

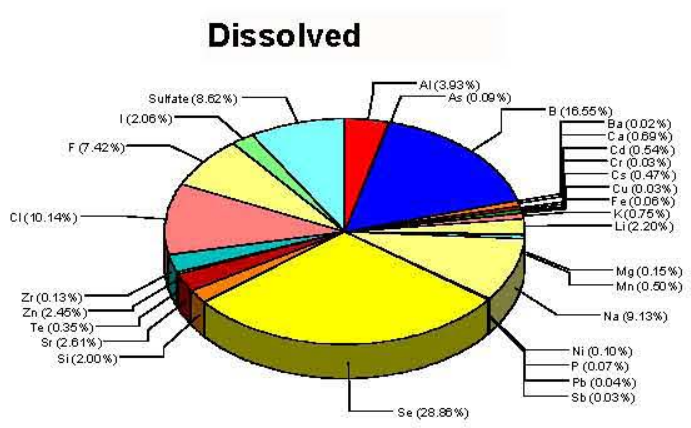

Figure 4.24. Comparison of compositions of SBS liquid dissolved and suspended fractions with that of the feed material from DM1200 commissioning tests. 


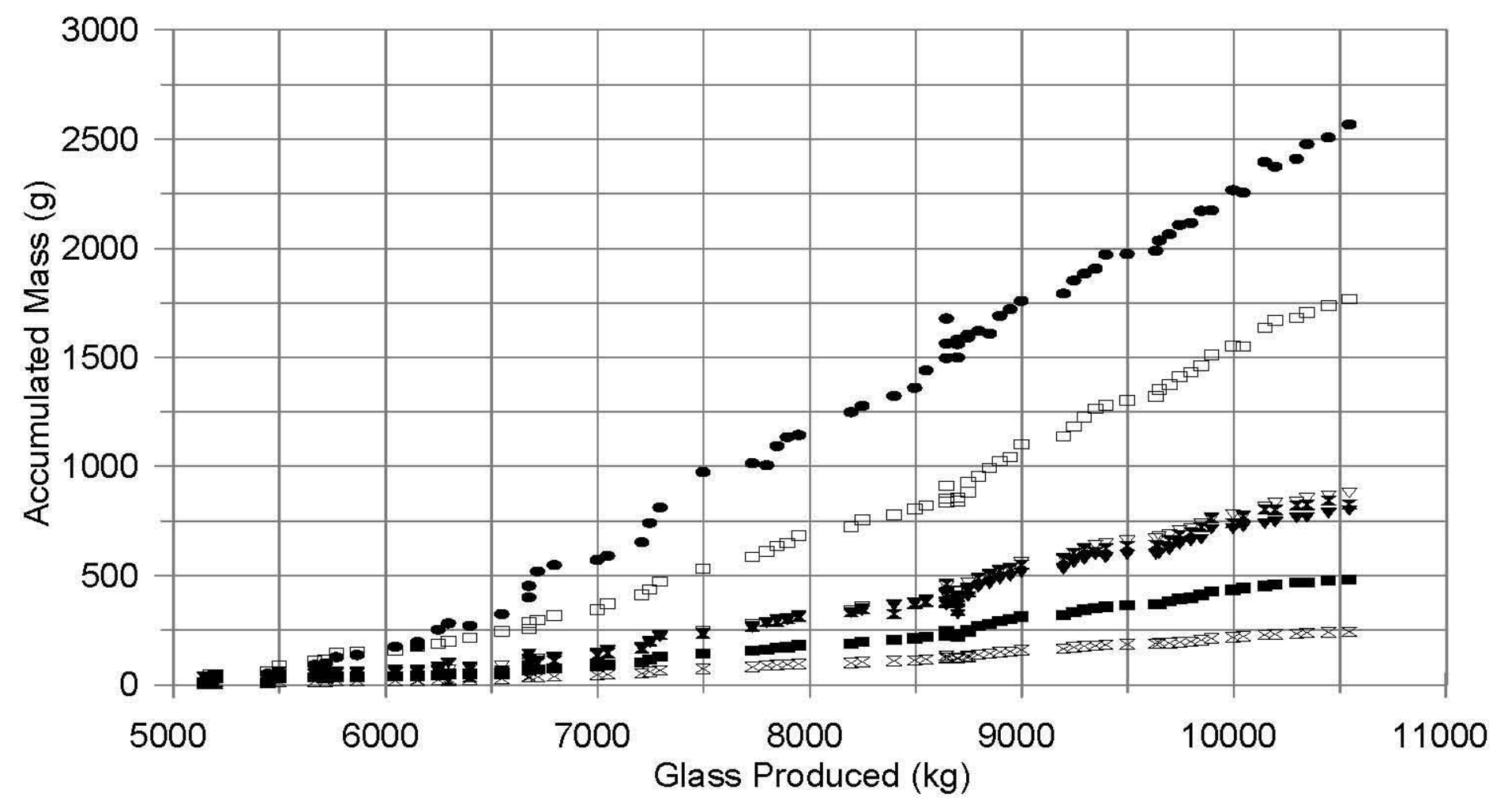
- $A$
ㅁ B
$\mathrm{Fe}$
$\nabla \mathrm{Na}$
Se
× $\mathrm{Si}$
× $\mathrm{Zn}$

Figure 4.25. Accumulations of major constituents in SBS fluids during DM1200 commissioning tests. 

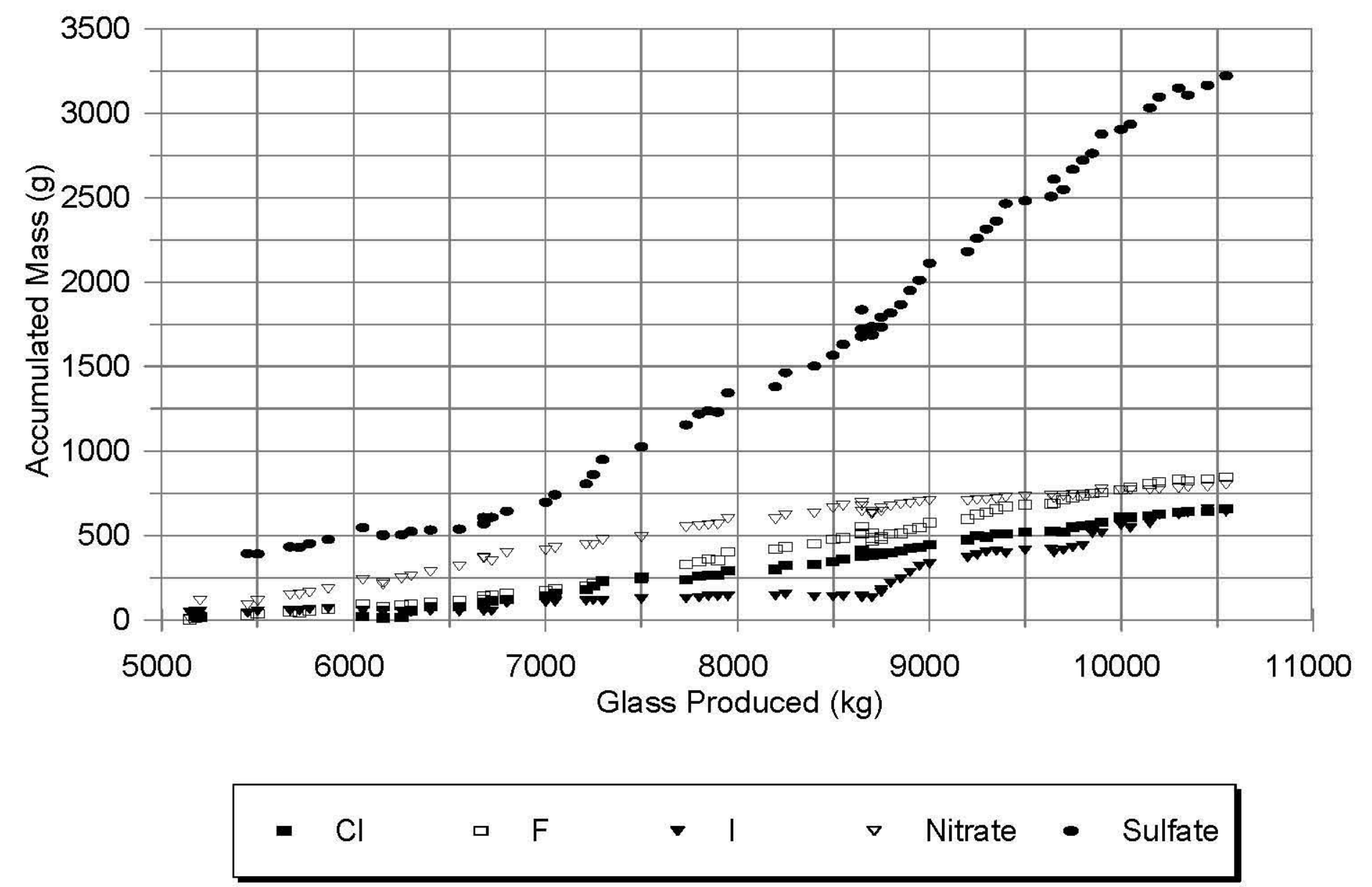

Figure 4.26. Accumulations of anions in SBS during DM1200 commissioning tests. 


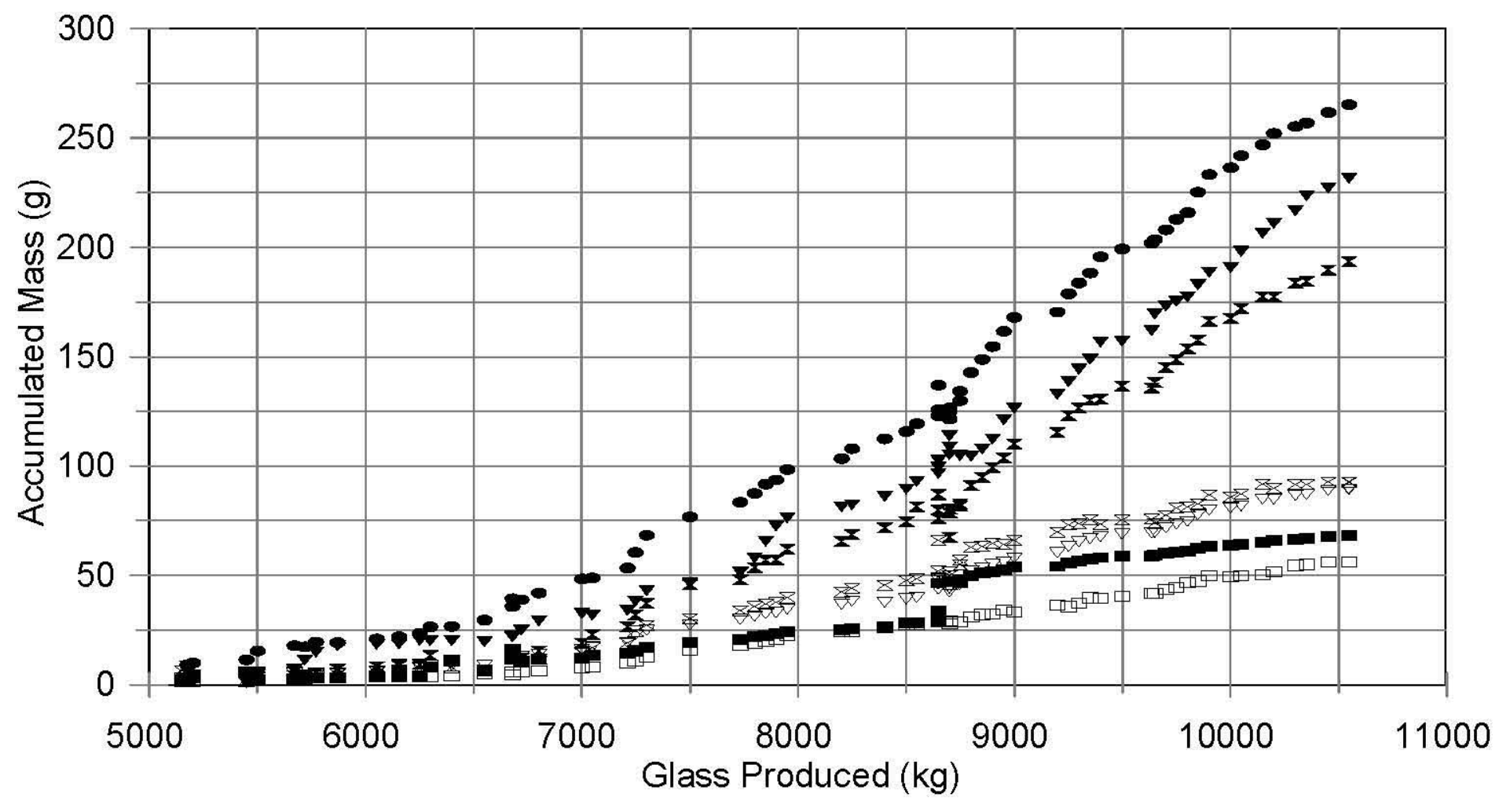

- $\mathrm{Ca}$ 口 $\mathrm{Cs} \nabla \mathrm{Li} \nabla \mathrm{Mn} \bullet \mathrm{Sr}$ × $\mathrm{Te}$ × $\mathrm{Zr}$

Figure 4.27. Accumulations of select constituents in SBS during DM1200 commissioning tests. 

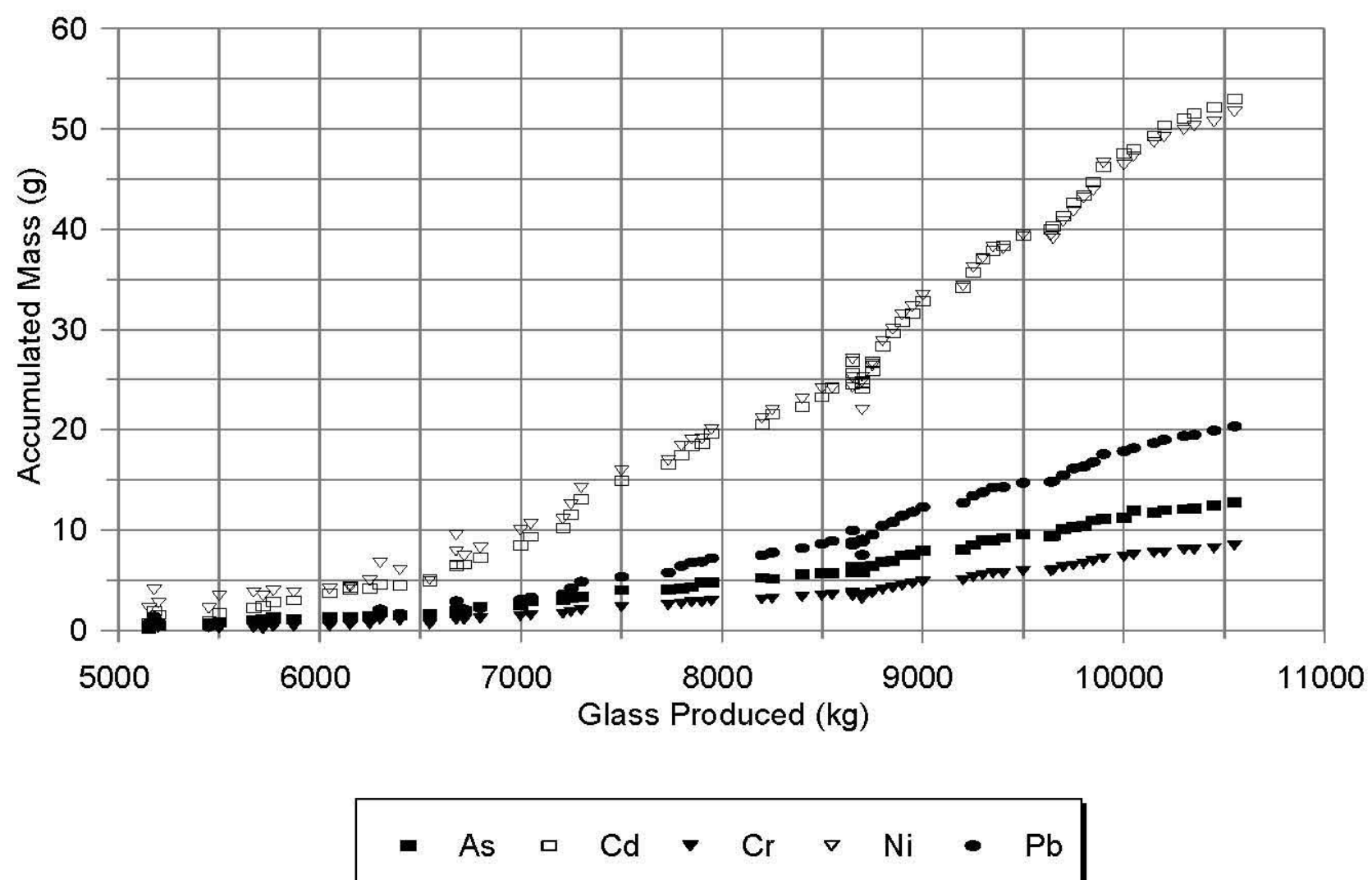

Figure 4.28. Accumulations of RCRA metals in SBS during DM1200 commissioning tests. 

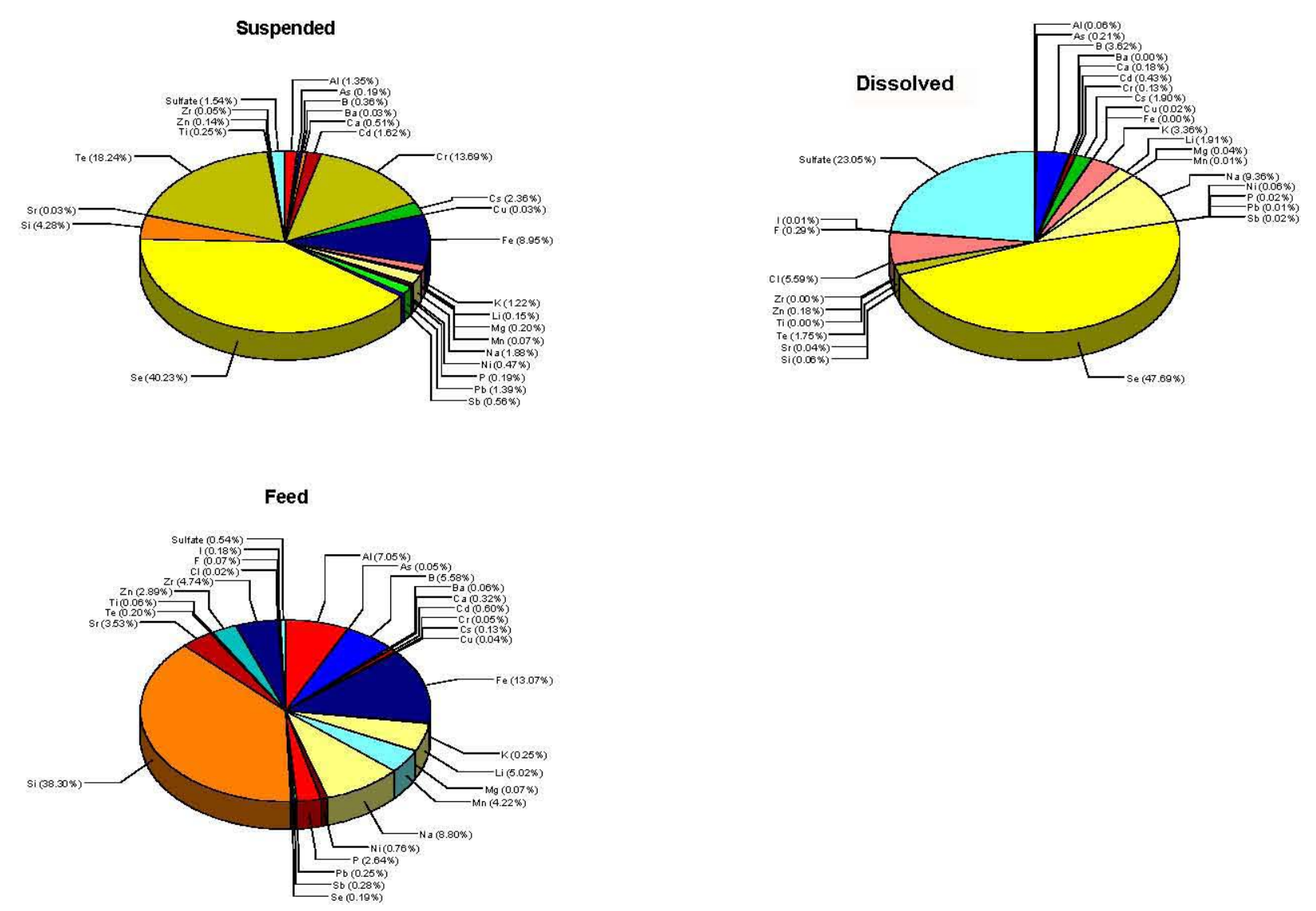

Figure 4.29. Comparison of compositions of WESP liquid dissolved and suspended fractions with that of the feed material from DM1200 commissioning tests. 


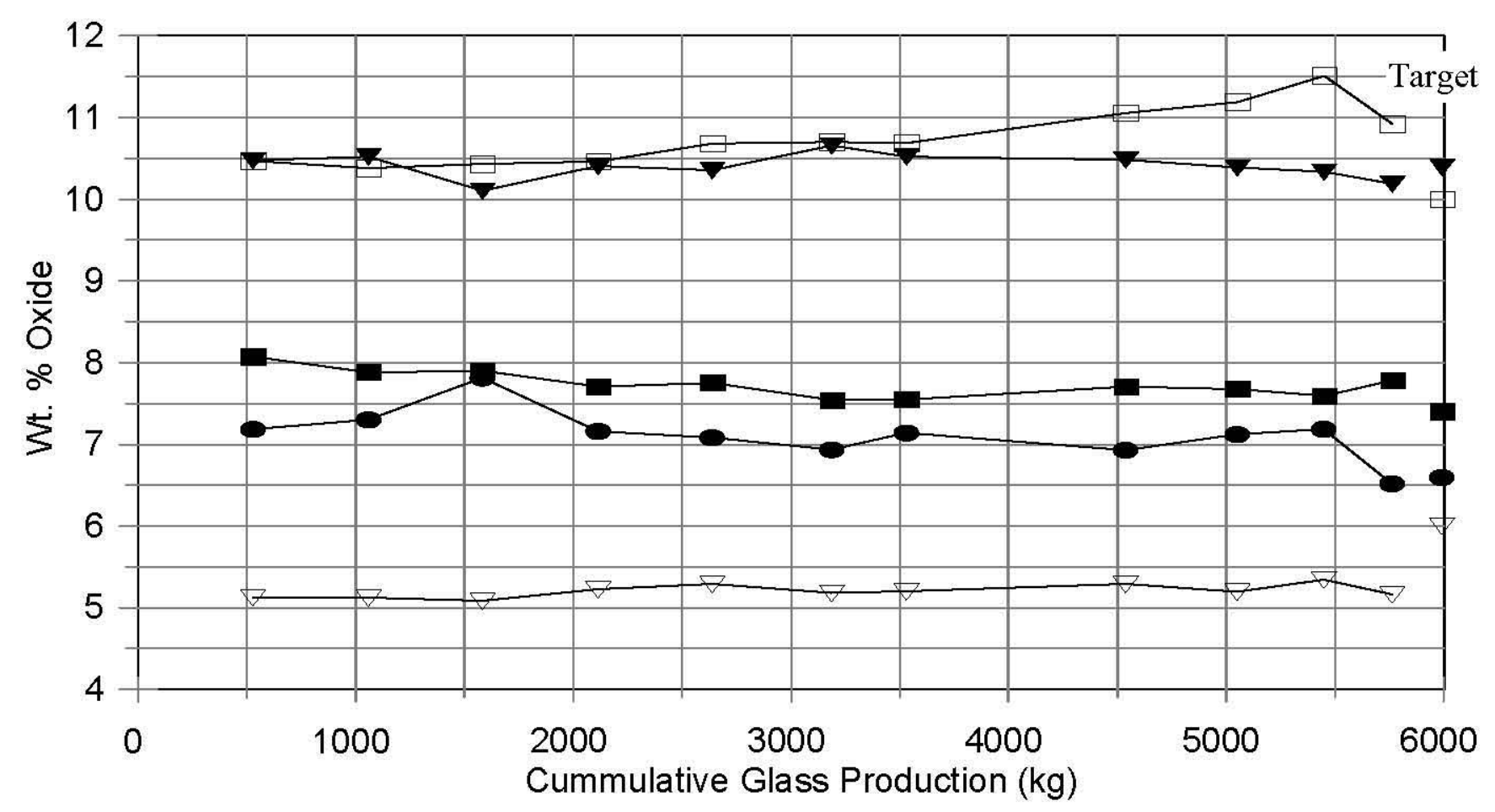

Figure 5.1. Analyzed product glass compositions for major oxides during DM1200 commissioning Tests 1,2, and 3. 


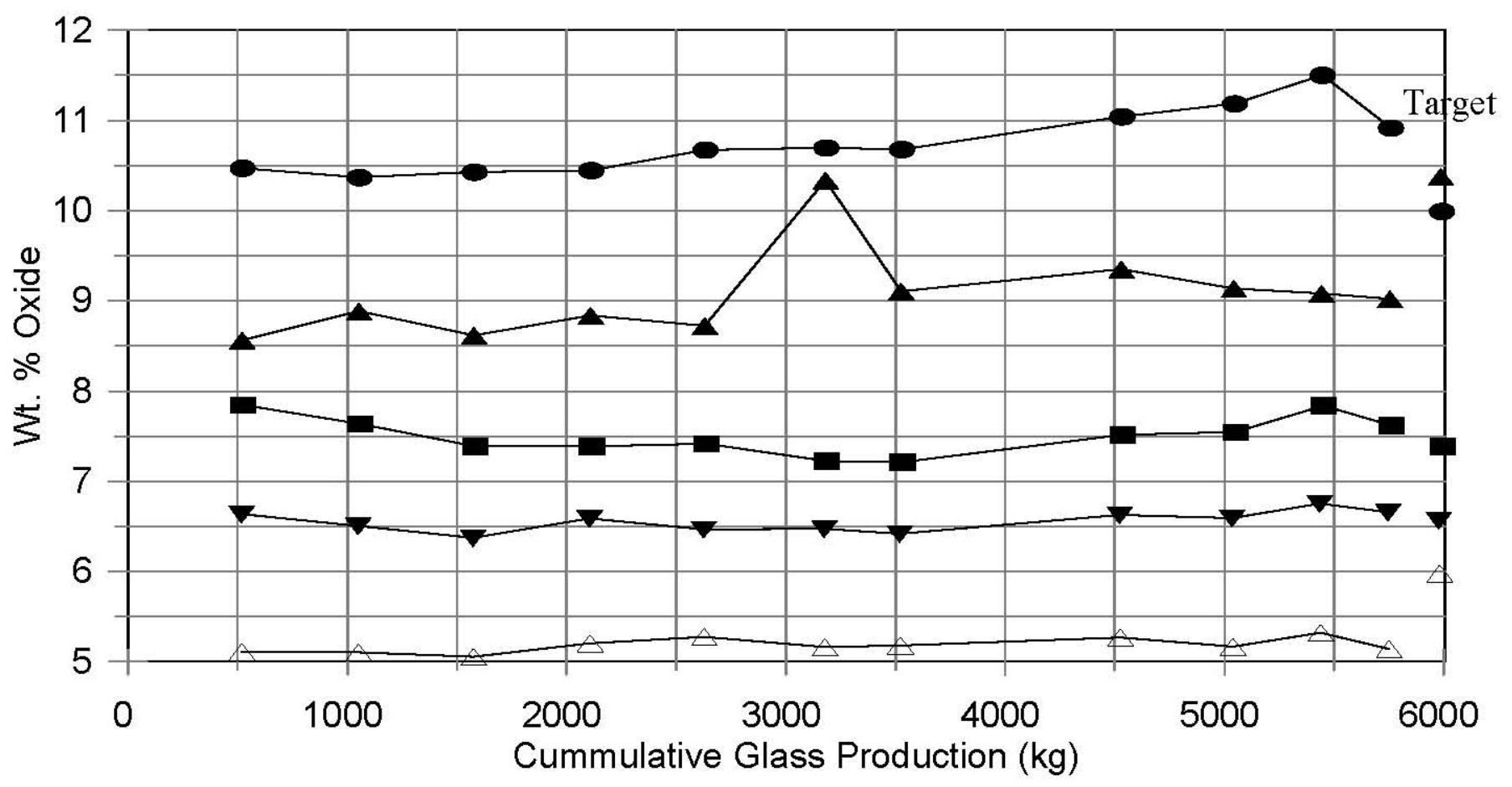

Figure 5.2. DCP analyzed product glass compositions for major oxides during DM1200 commissioning tests 1, 2 , and 3. 


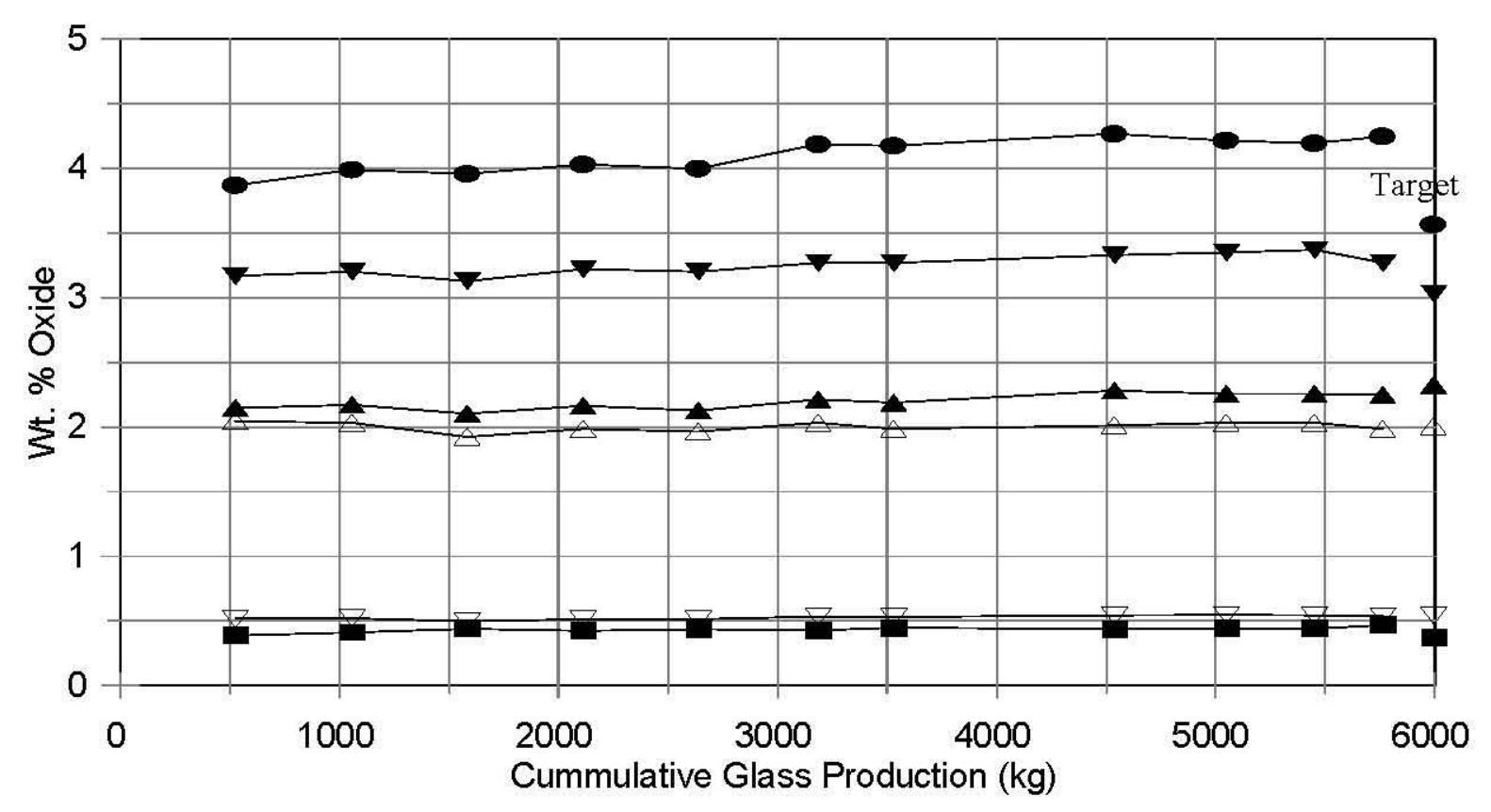

Figure 5.3. XRF analyzed product glass compositions for select oxides during DM1200 commissioning Tests 1, 2, and 3. 


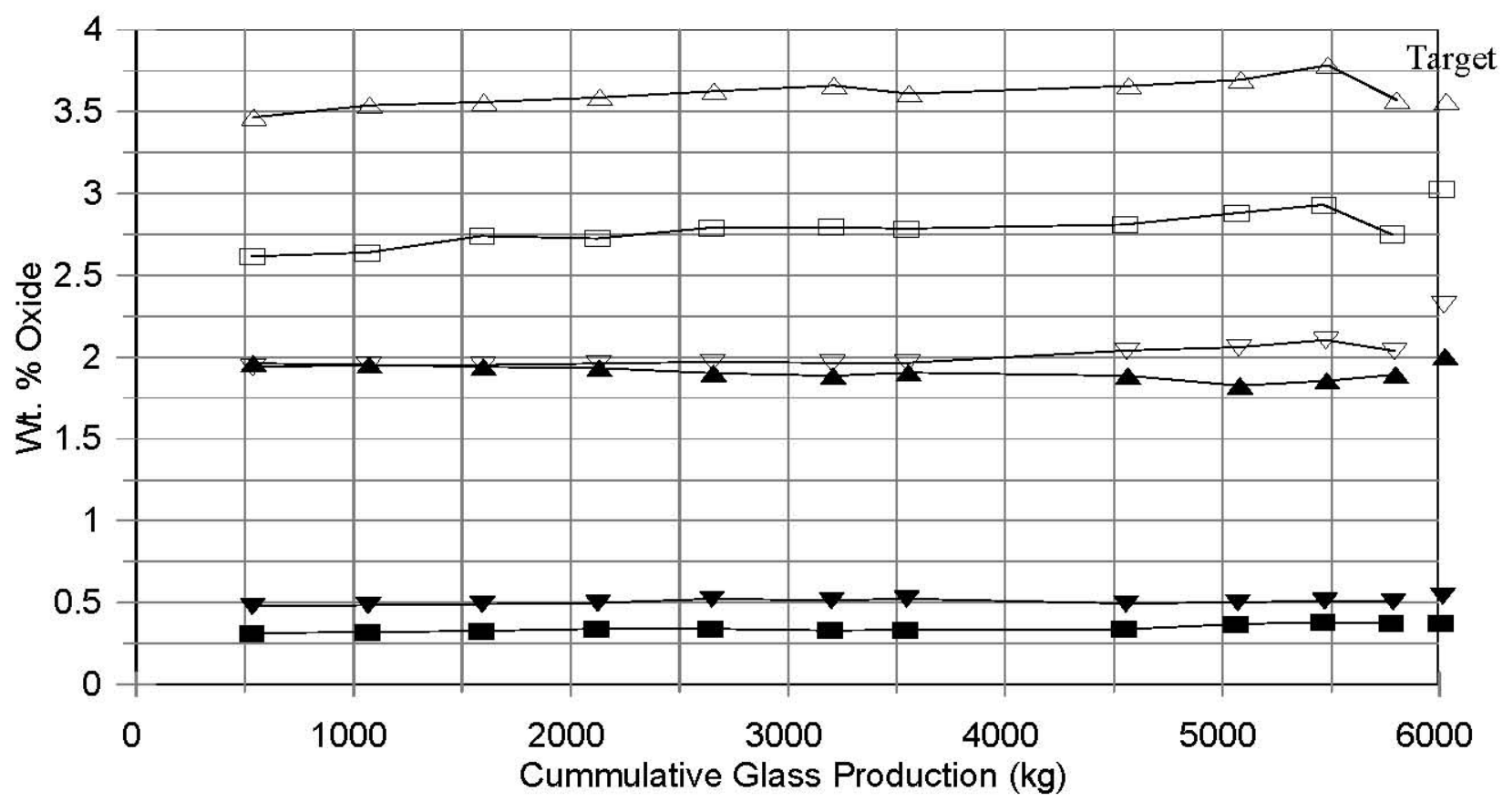

$\neg-\mathrm{Cd} \square \mathrm{Mn} \rightarrow \mathrm{Ni} \rightarrow \mathrm{Sr} \bullet \mathrm{Zn} \triangle \mathrm{Zr}$

Figure 5.4. DCP analyzed product glass compositions for select oxides during DM1200 commissioning Tests 1,2 , and 3. 


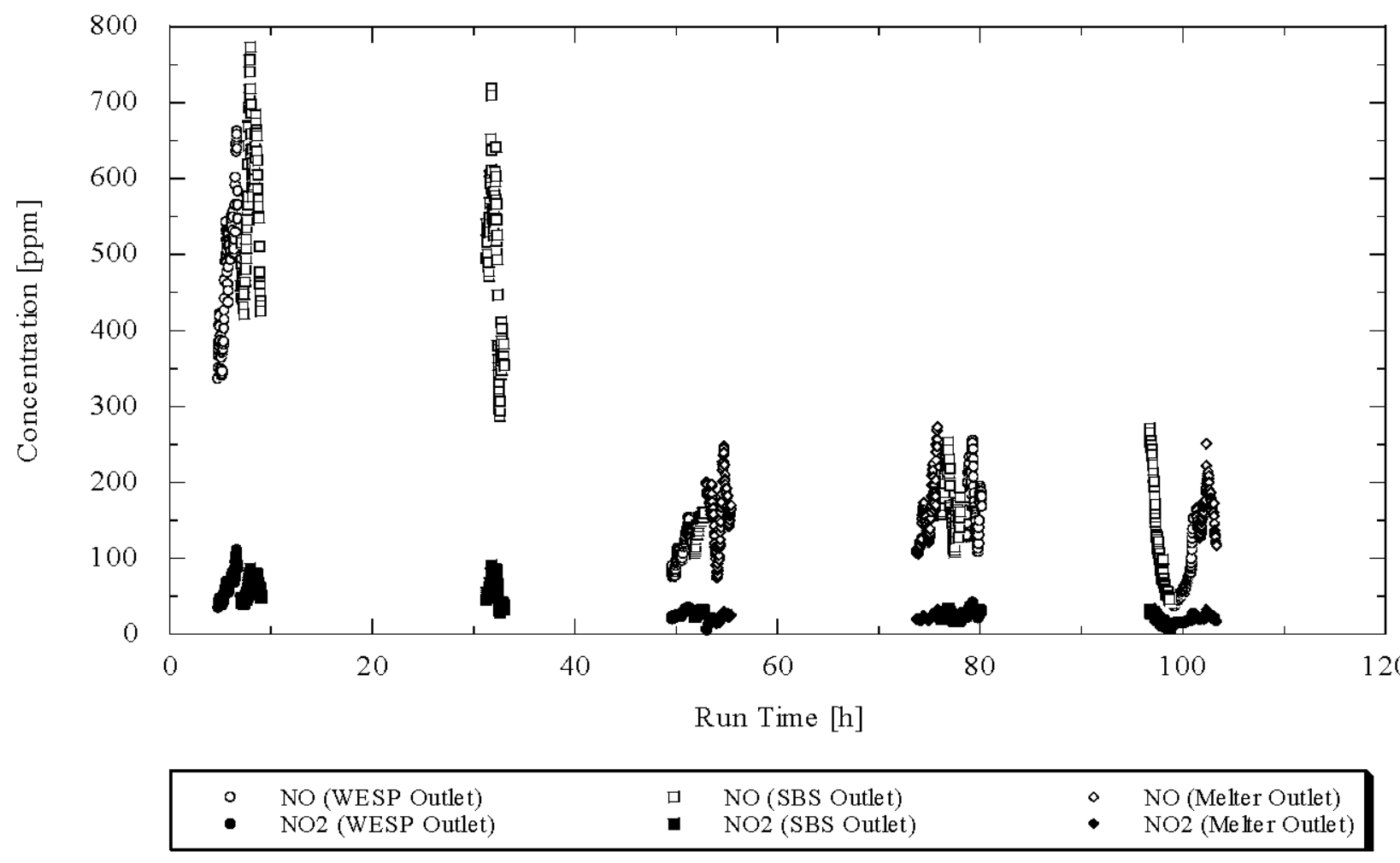

Figure 6.1. Concentration of $\mathrm{NO}$ and $\mathrm{NO}_{2}$ in exhaust during DuraMelter $1200 \mathrm{AZ}-101$ commissioning Test 1. 


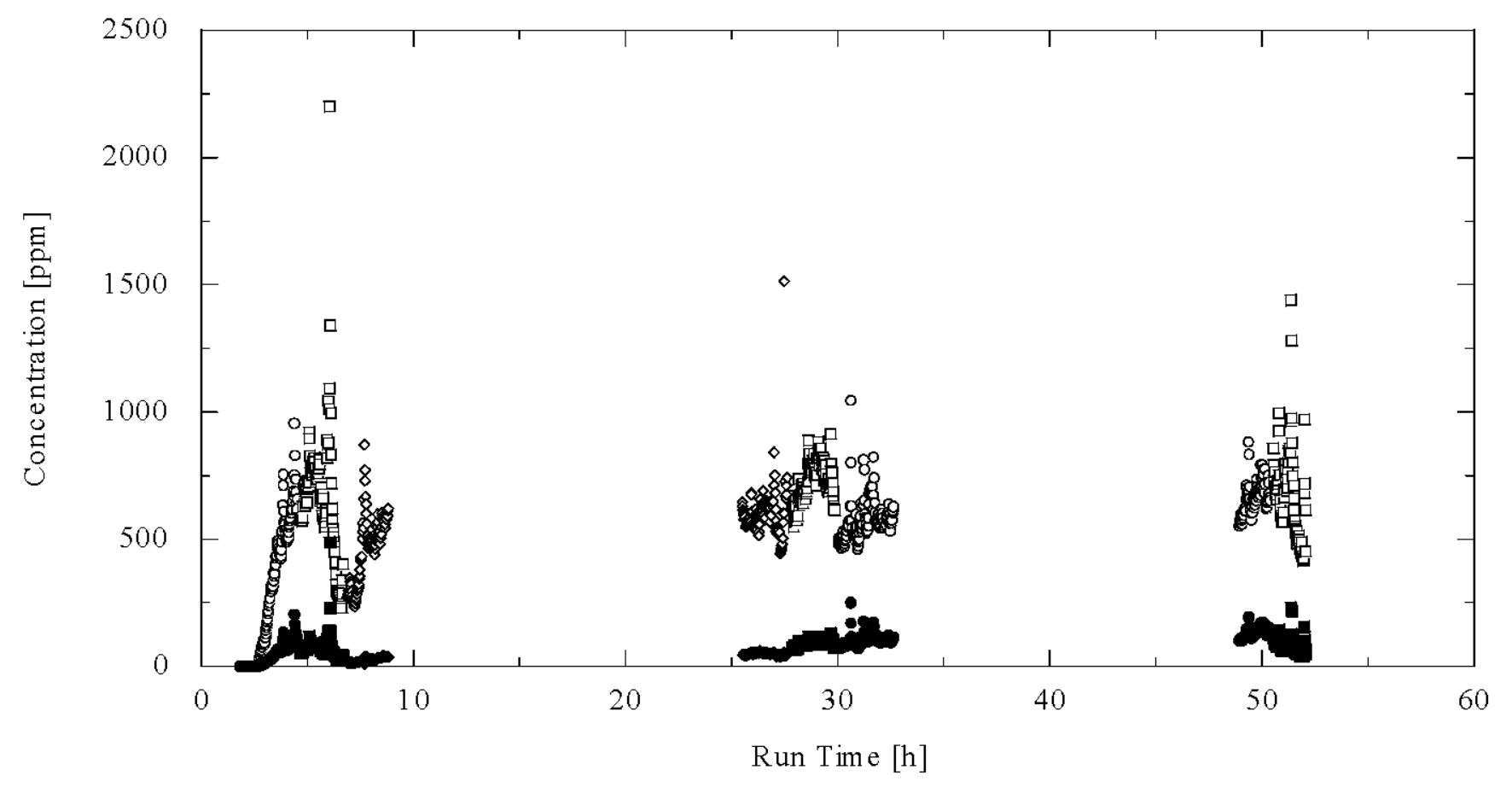

\begin{tabular}{|llllll|}
\hline$\circ$ & NO (WESP Outlet) & $\square$ & NO (SBS Outlet) & NO (Melter Outlet) \\
$\bullet$ & NO2 (WESP Outlet) & $\square$ & NO2 (S BS Outlet) & $\bullet$ & NO2 (Melter Outlet) \\
\hline
\end{tabular}

Figure 6.2. Concentration of $\mathrm{NO}$ and $\mathrm{NO}_{2}$ in exhaust during DuraMelter $1200 \mathrm{AZ}-101$ commissioning Test 2. 


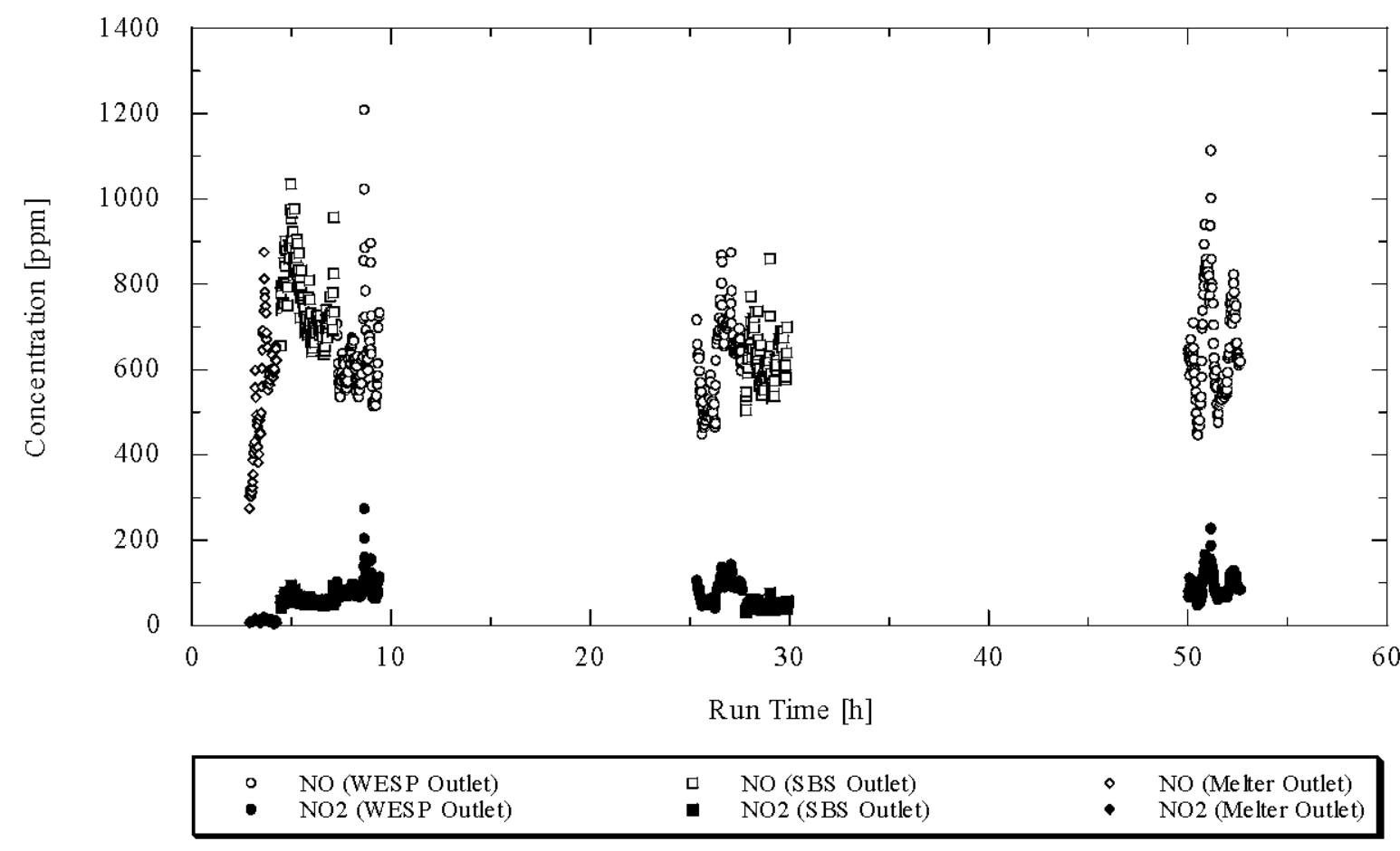

Figure 6.3. Concentration of $\mathrm{NO}$ and $\mathrm{NO}_{2}$ in exhaust during DuraMelter $1200 \mathrm{AZ}-101$ commissioning Test 3 . 


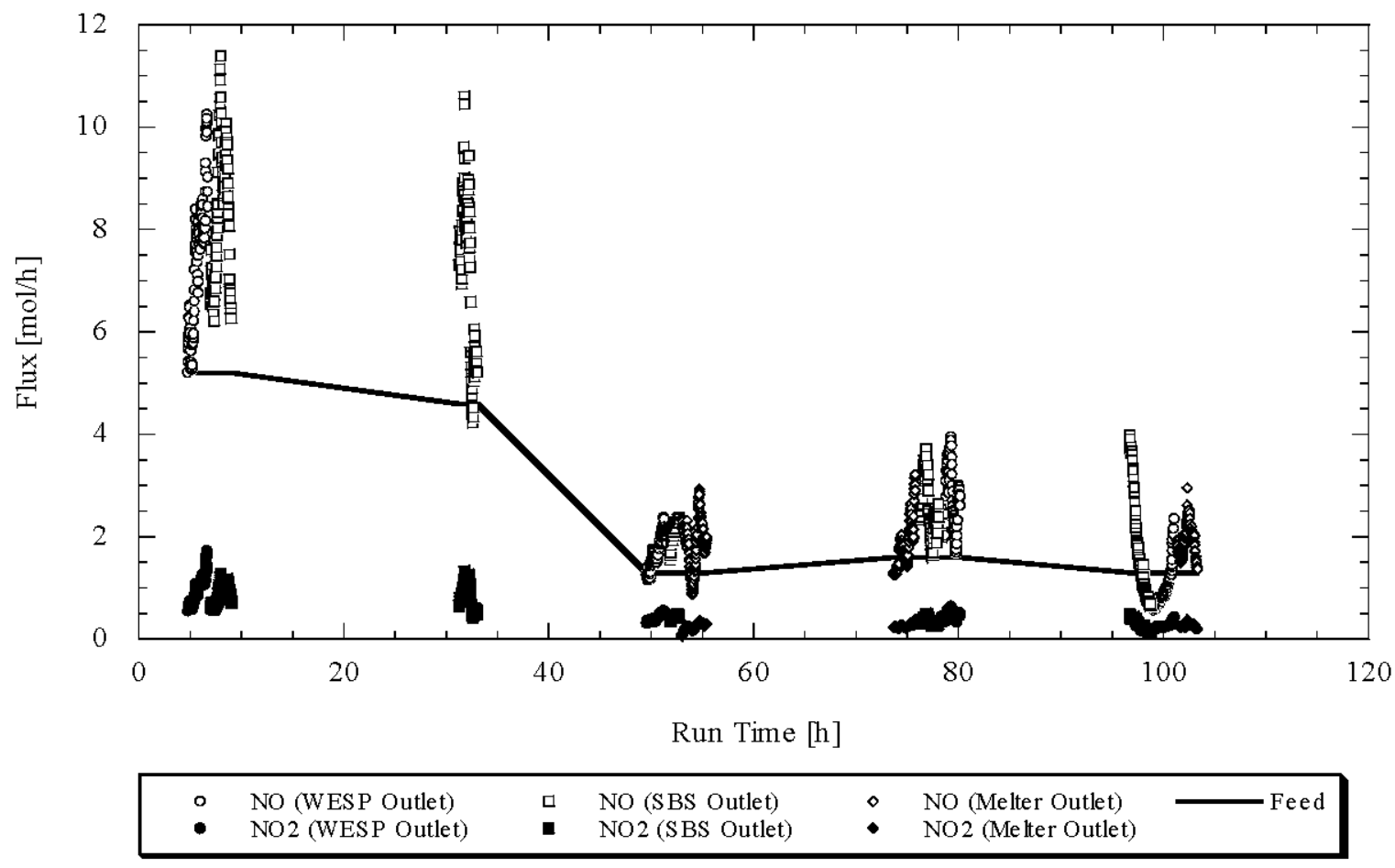

Figure 6.4. $\mathrm{NO}$ and $\mathrm{NO}_{2}$ exhaust fluxes during DuraMelter $1200 \mathrm{AZ}-101$ commissioning Test 1. 


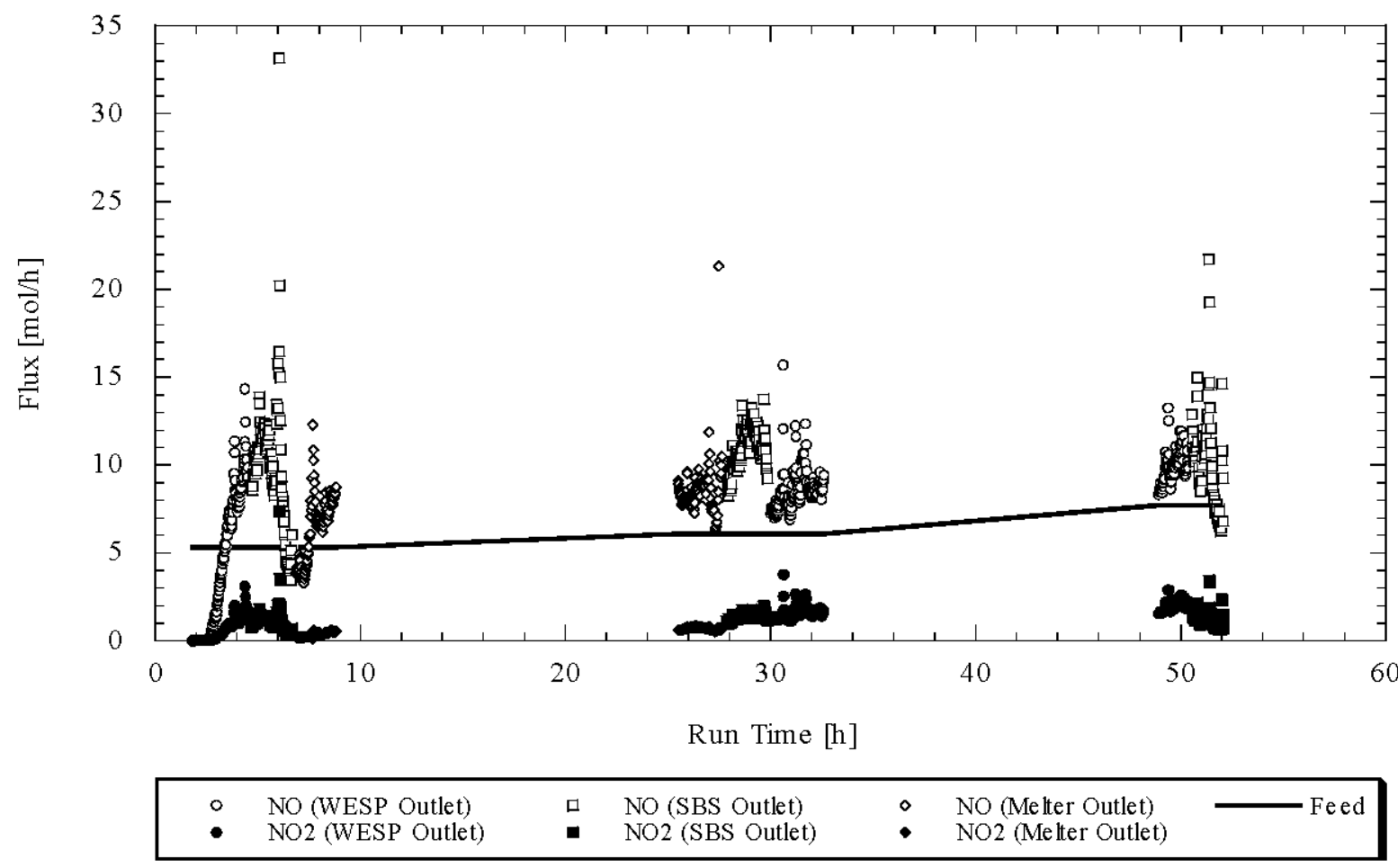

Figure 6.5. $\mathrm{NO}$ and $\mathrm{NO}_{2}$ exhaust fluxes during DuraMelter $1200 \mathrm{AZ}-101$ commissioning Test 2 . 


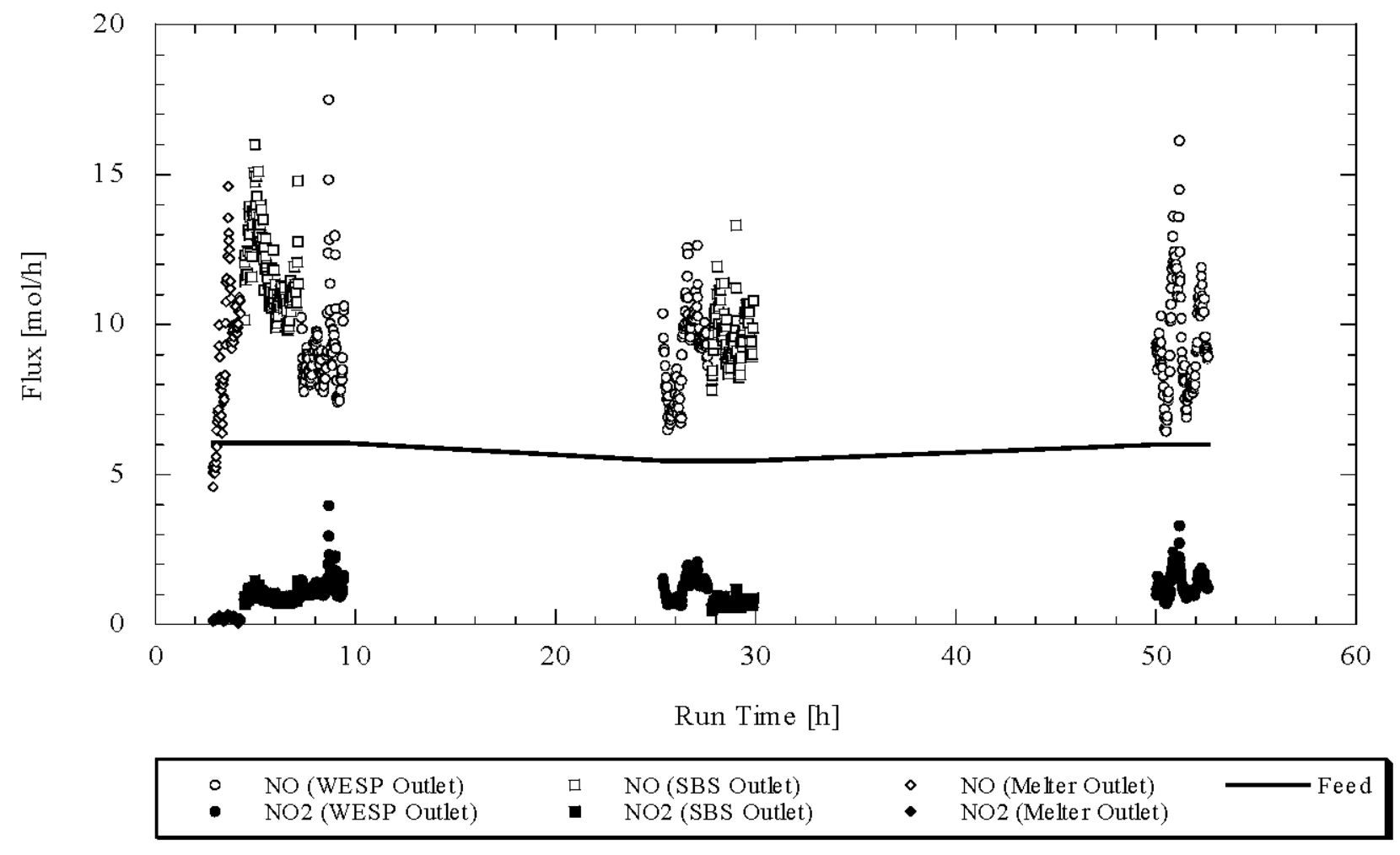

Figure 6.6. $\mathrm{NO}$ and $\mathrm{NO}_{2}$ exhaust fluxes during DuraMelter $1200 \mathrm{AZ}-101$ commissioning Test 3 . 